UNIVERSIDADE DE SÃO PAULO

FACULDADE DE FILOSOFIA, LETRAS E CIÊNCIAS HUMANAS

DEPARTAMENTO DE GEOGRAFIA

PROGRAMA DE PÓS-GRADUAÇÃO EM GEOGRAFIA HUMANA

Artur Attarian Cardoso Camarero

No relógio 19:15, passados mais de 100 anos em guerra 
UNIVERSIDADE DE SÃO PAULO

FACULDADE DE FILOSOFIA, LETRAS E CIÊNCIAS HUMANAS

DEPARTAMENTO DE GEOGRAFIA

PROGRAMA DE PÓS-GRADUAÇÃO EM GEOGRAFIA HUMANA

Artur Attarian Cardoso Camarero

No relógio 19:15, passados mais de 100 anos em guerra

Dissertação de Mestrado apresentada ao Programa de Pós-graduação em Geografia Humana da Faculdade de Filosofia, Letras e Ciências Humanas da Universidade de São Paulo, para obtenção do título de Mestre em Geografia sob a orientação do Prof. Dr. Heinz Dieter Heidemann. 


\section{Ficha de Aprovação}

Autor: Artur Attarian Cardoso Camarero

E-mail: artur.attarian@gmail.com

Orientador: Prof. Dr. Heinz Dieter Heidemann

Título: No relógio 19:15, passados mais de 100 anos em guerra

Dissertação apresentada ao Programa de Pós-graduação em Geografia Humana da Faculdade de Filosofia,

Letras e Ciências Humanas da Universidade de São Paulo, para obtenção do título de Mestre em Geografia.

\section{Banca examinadora:}

$\operatorname{Prof}(\mathrm{a}) \cdot \operatorname{Dr}(\mathrm{a})$.

Instituição: Assinatura:

Prof(a). Dr(a).

Instituição: Assinatura:

Prof(a). Dr(a).

Instituição: Assinatura:

Prof(a). Dr(a).

Instituição: Assinatura:

Aprovado em: 


\section{$\underline{\text { Resumo }}$}

Esta dissertação de início trata das particularidades do processo de mobilização pelo trabalho da imigração armênia no Distrito de Presidente Altino, localizado no município de Osasco, em relação com a capital paulista. Esse processo tem como referencial histórico de mobilização o Genocídio Armênio perpetrado pelo Império Otomano durante a Primeira Guerra Mundial (1914-1918), intepretada aqui a partir da mobilização geral (Gaudemar, 1981), momento histórico em que todos os esforços estão voltados para a produção, fazendo da guerra uma constante necessária à acumulação de capitais. Tentamos problematizar os desdobramentos históricos da relação social capitalista que foram transformando os sentidos da acumulação de capitais ao longo do século XX, bem como a dinâmica das personificações daí resultantes, até o contemporâneo capitalismo baseado na reprodução ficctícia do valor. Partindo da pesquisa histórica de trajetórias de mobilização aliada a observações feitas em trabalhos de campo, foram realizadas viagens à Argentina, Uruguai no intuito de apresentar as contradições perceptíveis entre a identidade armênia dessas localidades visitadas e a identidade observada em viagem à Armênia.

Palavras-chave: Armênia, Genocídio Armênio, migrações, identidade armênia, mobilização geral.

\section{$\underline{\text { Abstract }}$}

This dissertation deals with the particularities of the process of mobilization for the work of Armenian immigration in the District of Presidente Altino, located in the municipality of Osasco, in relation to the capital of São Paulo. This process has as a historical reference for mobilization the Armenian Genocide perpetrated by the Ottoman Empire during World War I (1914-1918), interpreted here using the concept of general mobilization (Gaudemar, 1981), historical moment in which all the efforts are directed to the production, requiring constant war to the accumulation of capital. We have tried to problematize the historical unfoldings of the capitalist social relationship that have been transforming the meanings of capital accumulation throughout the twentieth century, as well as the dynamics of the personifications resulting therefrom reaching the contemporary capitalism based on the fictional reproduction of value. Starting from the historical research of mobilization trajectories allied to observations made in field research. Travels were made to Argentina, Uruguay in order to present the perceptible contradictions between the Armenian identity of these visited localities and the identity observed during the travel to Armenia.

Keywords: Armenia, Armenian Genocide, migrations, armenian identity, general mobilization. 



\section{Sumário}

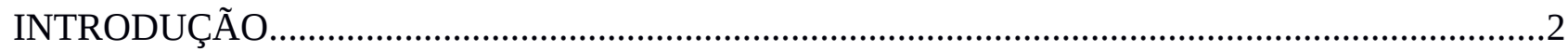

PARTE UM - Refugiados fazendo a América................................................................................

1.1) Presidente Altino, 15 de dezembro de 2015.......................................................................10

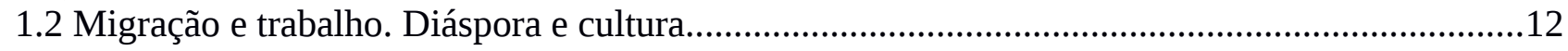

1.3) Entrevista com Armênio Burbulhan............................................................................................15

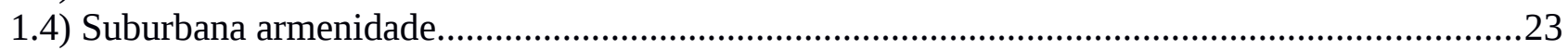

1.5) Patriarcado, crédito a homens de valor...................................................................................4

1.6) Entrevista com Hampartsum Moumdjian..................................................................................54

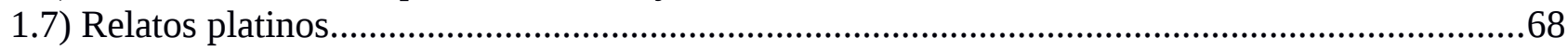

PARTE DOIS - No relógio 19:15, passados mais de 100 anos em guerra..........................................95

2.1) Yerevan, 03 de outubro......................................................................................................96

2.2) A paternidade histórica da Questão Armênia.............................................................................104

2.3) Yerevan, 22 de setembro de 2016.................................................................................114

2.4) O boom de 1914 ......................................................................................................... 118

2.5) Mobilização geral e extermínio como acumulação de capital na formação nacional da Turquia

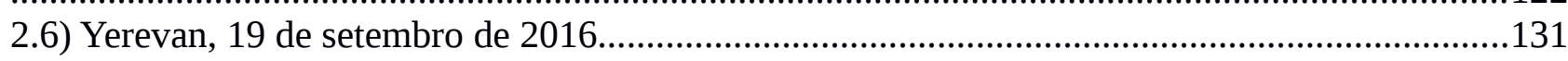

2.7) Yerevan, 10 de outubro....................................................................................................135

2.8) Shushi, 14 de outubro de 2016........................................................................................139

2.9) Kapan, 13 de novembro de 2016 ............................................................................................154

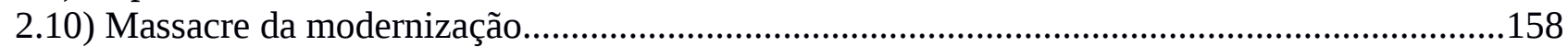

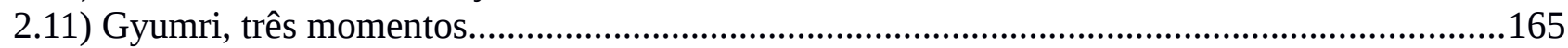

2.12) Tripla Entrevista: anos escuros e frios..............................................................................170

2.13) Yerevan, 02 de novembro - empreendedorismo social, o capitalismo de bom coração..........173

2.14) Da modernização retardatária ao pulo do sapo.....................................................................175

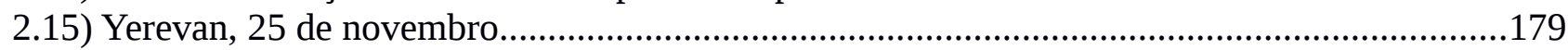

2.16) Entrevista com Lilit....................................................................................................

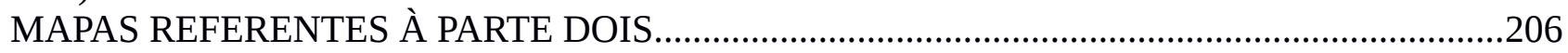

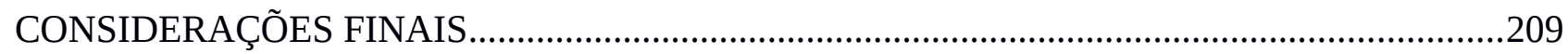

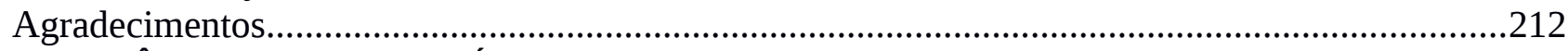

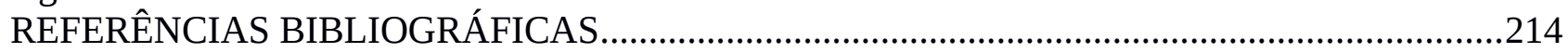




\section{INTRODUÇÃO}

O texto apresentado é marcado por diferenças significativas entre suas duas partes. Estas diferenças referem-se tanto a estilo quanto a densidade de revisão bibliográfica, ainda que o trabalho de campo esteja presente como principal estratégia de pesquisa em ambas as partes. Desta forma, não foi possível realizar revisões bibliográficas na mesma profundidade sobre a história das várias localidades quando nos encontrávamos na posição de pesquisador-imigrante. No entanto, sem a apresentação deste conjunto de estranhamentos estrangeiros, a Dissertação perderia seu foco central que é apresentar as contradições perceptíveis na identidade armênia que se expressa nas localidades visitadas.

De um lado, a escrita acadêmica que lida nos pormenores dos argumentos com diversos debates e autores, longas citações e sem brincadeiras, mas nas entrelinhas alguma fé duvidosa no discurso científico e na sua forma. De outro lado, os cadernos de campo, diversas vezes apresentados diretamente, com muitos relatos de viagem que, já no primeiro - realizado no final de 2015 em Presidente Altino - ganhavam um tom impreciso, rápido, que mistura sem dispor de explicações explícitas ou de motivações teóricas claras, contando “causos” que vinham por outras bocas, bocas desautorizadas pela ciência na maioria das vezes, ou, na maioria dos casos, para ser mais científico. Mas o prisma do nosso olhar, bem ou mal, parece estar autorizado a relatar sobre o que acontece no dia a dia em relação ao que aqui se estuda: as formas da representação da assim chamada armenidade em diversos contextos e momentos históricos, dentro e fora da Armênia, pensados pela teoria do valor-dissociação. Outras bocas nos levam a lugares que desconhecemos também. Afinal, não é da Geografia o trabalho de campo? Mesmo que sempre com o fetichismo da mercadoria na cabeça para daí observar a superfície das mercadorias, o processo de trabalho ali, no meio da rua, passou às minhas costas, e organizar informações tão variadas, tarefa da qual faz parte o tal trabalho de escrever, se impôs, feito fantasma, tendo de ser feito no espaço privado do bureau, entre papéis e de olho na tela, mas com a memória voltada para os dias experimentados durante os trabalhos de campo. São Paulo, Osasco, Porto Alegre, Montevidéu e Piriápolis no Uruguai, Buenos Aires na Argentina, Yerevan, Gyumri, Kapan e tantos outros cantos da Armênia, como Nagorno-

Karabakh, por exemplo, onde topamos com uma das "guerras de baixa intensidade" que acometem a realidade atual.

Assim, a prática do trabalho de campo abriu, e segue abrindo, a possibilidade para pensarmos nas diferenças e semelhanças entre os distintos grupos armênios e suas correspondentes formas ou “estratégias” de representação identitária. Vale dizer que não buscamos simples 
comparações, mas observações de contextos particulares que remetem à contradição em processo da modernização das relações capitalistas. Já nos relatos platinos, ao final da primeira parte, foi aparecendo cada vez mais o problema da diferença da representação da identidade dos hayastantsi (quem nasce na Armênia) e os spyurqhay (a assim chamada diáspora armênia de todo o mundo). A tematização da experiência particular deste pesquisador-imigrante, mais uma figura do espetáculo, não deixa de ser uma destas formas ou “estratégias”. Esse trabalho poderia ter trilhado diversos caminhos dada a amplitude do tema, mas a estratégia reflexiva de pesquisador-imigrante permite apresentar a contradição nos implicando no processo e estudar a identidade armênia nos levou, com inquietação, a vários lugares e contextos.

Nesse sentido, não se trata de um não posicionamento, mas de um posicionamento que busca apresentar as contradições de modo a revelar sua falta de autonomia em relação ao processo mais amplo da modernização (Kurz, 1992), e também ao da mobilização geral (Gaudemar, 1981), da mobilização do trabalho (Gaudemar, 1977), da sociedade do espetáculo (Debord, 1997) e da urbanização crítica (Damiani, 2004). Remeter a essas teorias que pensam a totalidade da relação social capitalista a partir de problemas particulares foi o que tentamos fazer ao longo do texto: em muitas passagens abruptamente e em outras de maneira mais detalhada. A observação cotidiana permitiu, acompanhada de uma base teórica determinada, perceber a unidade do processo que configura contextos particulares da modernização como totalidade.

Pode-se dizer, ainda, que só é possível perceber a totalidade em suas formas de manifestação particulares. A relação entre valores que forma a totalidade das mercadorias em circulação aparece como trocas de valores de uso, ou ainda, formas particulares de manifestação do capital. Mas como observa Marx astutamente, as mercadorias não vão sozinhas ao mercado. Seus proprietários aparecem como suas personificações ${ }^{1}$, a ponto de serem estabelecidas relações de representação identitária que se utilizam de valores de uso. Como visto já nos estudos do Trabalho de Graduação Individual (TGI) quando perguntamos se "a mercadoria calçado objetiva 'qualidades armênias intrínsecas’ no discurso que se produz sobre armenidade enquanto identidade”.

Ao lidar com a categoria personificação seria necessário refletir criticamente sobre as relações que mediam personas do capital como patriarcas, no sentido da teoria do valor-dissociação. Por isso, houve o esforço para problematizar tanto a questão de gênero quanto a questão étnica em suas manifestações empíricas. Este esforço esteve presente nas preocupações desta pesquisa, mas resta acentuar que o trabalho de campo não acessa com facilidade essas relações que muitas vezes se dão no âmbito privado.

1 De acordo com o que foi dito por Marx no segundo capítulo de $O$ capital: "os personagens econômicos encarnados pelas pessoas nada mais são que as personificações das relações econômicas, como portadores das quais elas se defrontam" (1984: 80). 
A experiência do pesquisador-imigrante que atravessa os relatos de campo, tanto dentro (in) quanto fora (out), pode trazer questões acerca da objetividade do discurso de aparência neutra que é próprio da ciência, sobrando a quem for ler apenas a opção de embarcar na viagem alheia, se implicar em um texto permeado de subjetividade, concordas?

No entanto, a subjetividade é parte de uma contradição em processo da objetividade social fetichista própria da relação capitalista. Salientar isso é importante para a demarcação de nossa chave de interpretação teórica, pois sem ela a subjetividade que observa a superfície das mercadorias não é capaz de criticar - por exemplo, o trabalho, a mercadoria, o Estado, o direito, o dinheiro - as categorias da relação social capitalista. Por isso, refutamos insistentemente a perspectiva da ontologia de uma cultura armênia, perspectiva essa que reconhecemos, no início da segunda parte, como momento de hipostasia do nacional. Faz-se necessário levar a cabo uma crítica ao nosso tempo que esteja também entrosada pela crítica da forma de pensar que constitui a relação social capitalista e é nesse sentido que estamos de acordo com Heidemann ao dizer que:

\footnotetext{
No processo concreto da realidade, na crítica da ideologia e das configurações de sua história, as categorias não são congeladas, e a análise concreta histórica aponta para determinações categoriais. Por meio de mediações concretas, chegamos a um entendimento de diversos fenômenos empíricos das migrações: chauvinismo, sexismo, precarização, etc (Heidemann, 2010: 26-27).
}

Sabendo que a forma monográfica impõe demandas que os relatos não superam e vice-versa, tivemos que enfrentar bibliografias que tratam da história do Genocídio Armênio e a armenidade na forma de suas manifestações particulares situando-as, a todo momento, no interior do processo de modernização relativo à reprodução do capital. Tentamos tratar o Genocídio Armênio e a armenidade como uma contradição em processo, saindo da aparência de algo específico, autonomizado e frequentemente naturalizado pelo discurso da cultura trans-histórica que demarca a identidade de um povo. Assim, tentamos mover uma contradição em processo e observar que esta orienta discursos, práticas sociais, mobilizando, a um só tempo, afetos e fontes de rendimento sob o signo de uma sociedade que vive o “totalitarismo da economia”. Já não há algo que esteja fora, nem pesquisador, nem imigrante, tampouco a assim chamada armenidade. Com isso, a forma da redação final relaciona situações vividas no cotidiano fetichista de pesquisador-imigrante - sem esquecer que as personificações que nos cabem vão além dessas duas - com a crítica da forma da mercadoria e o processo de modernização que esbarra atualmente nos limites históricos da sociedade produtora de mercadorias ao acumular barbárie. 


\section{Apresentação}

A apresentação dos diferentes contextos foi realizada na Parte Um - Refugiados fazendo a América e na Parte Dois - No relógio 19:15, passados mais de 100 anos em guerra.

A primeira parte tenta dar continuidade às questões desdobradas no TGI concluído em 2013 intitulado “Armênios em São Paulo: mobilização e genocídio”, mas vale aqui lembrar que o processo de estudos nos levou para além da problemática inicial formulada naquela ocasião. A continuidade do TGI nos fez elaborar perguntas sobre a relação e as diferenças - notadas por Roberto Grün (1992) em “Negócios e Famílias: armênios em São Paulo” - entre a comunidade armênia de Presidente Altino, representada como uma comunidade de vocação rural, e a comunidade da capital que ganha caracterização oposta, a de vocação urbana. Por meio de documentos da Comunidade Armênia de Osasco (CAO), certa revisão bibliográfica e entrevistas, tentamos demonstrar que a personificação dos armênios de Presidente Altino é muito mais complexa do que sugere o termo vocação rural, haja vista mover relações contraditórias na formação, na primeira metade do século XX, de um subúrbio.

O texto que serviu de base para nossa abordagem e traça essa formação do bairro é de autoria de dois autores significativos para a geografia brasileira: Pasquale Petrone e Antônio Rocha Penteado (1958). Contranitentes ao argumento de Grün, os geógrafos entendem que Presidente Altino figura como um dos bairros de “função industrial” na metrópole de São Paulo em formação. Embora teçamos críticas à concepção funcionalista presente neste texto, estamos de acordo com a interpretação de que a indústria foi importante na formação de Presidente Altino e no caso da comunidade armênia, o Frigorífico Wilson aparece como principal empregador e a Cerâmica Hervy como responsável pela venda e condições de pagamento dos lotes do bairro. A partir desse quadro de informações e referências, intentamos apresentar uma breve análise que nos levou menos a conclusões e mais a apontamentos sobre o nexo entre contexto da urbanização ali observada e a armenidade que se forjava no processo de autonomização das fontes de rendimento.

Antes dos relatos que encerram essa parte, tentamos esboçar uma crítica à aparência que encobria de "cultura” o elo que se estabelecia entre os armênios através da "ajuda-mútua”, relação esta bastante cara à Grün (1992). Aparência da cultura como esfera autônoma esconde a diferença entre classes sociais e a dominação patriarcal na representação naturalizada da "família armênia calçadista”. Para encerrar essa primeira parte, uma entrevista que prepara um pouco o terreno para os "Relatos platinos", quando fomos observar os atos realizados pela comunidade armênia de Buenos Aires referentes à memória do Genocídio Armênio em abril de 2016. 
Ainda como problemas abordados nesta primeira parte, podemos apontar para a apresentação da mobilização dos refugiados armênios em Presidente Altino, bem como de sua relação com a capital São Paulo e a constituição de uma comunidade armênia de bairro, no subúrbio de uma metrópole em formação. Nesse contexto se desenvolve um diálogo com a ideia de “inserção”, para utilizar o termo de Grün (1992), desses refugiados no processo da concentração de capitais e autonomização das fontes de rendimento a mover o que se apresenta como "urbanização crítica” (Damiani, 2004). Mas o campo em busca de outras formas de representação da armenidade e de "inserção" em Buenos Aires e no Uruguai figura como a primeira tentativa de extrapolar o recorte nacionalista e a escala da metrópole paulistana. A imigração foi a chave da internacionalização, por assim dizer, dos temas da pesquisa. A mobilidade do trabalho em sua dupla liberdade (Gaudemar, 1977: cap. V) se realiza onde a relação-capital estabeleceu territórios pacificados para o mercado, e a armenidade não é uma exceção que se sustenta por laços culturais imanentes e originários da era pré-cristã, mas representações e discursos que põem em movimento a força de trabalho na sobrevivência sob a economia de guerra mundializada desde $1914^{2}$. A crítica à noção culturalista da armenidade perpassa todo o argumento do texto, mas está exposta de maneira mais detida no terceiro item da primeira parte quando nos apoiamos teoricamente no conceito de mobilidade do trabalho de Jean Paul de Gaudemar (1977) e no relato inicial da segunda subsequente.

Na segunda parte, a vontade de implodir o recorte nacional nos levou para dentro da Armênia (Hayastan) e, como spyurqhay, afinal sou bisneto de armênios, fui fazer trabalho voluntário ${ }^{3}$ em Gyumri e Yerevan entre agosto e novembro de 2016, além de andar por outras partes. Se queria usar essa experiência como matéria para o texto, tinha a necessidade de observar, coletar informações, dados, histórias e novas bibliografias. O cotidiano exposto tornou-se o jeito possível de dar forma aos relatos dessa viagem, pois não poderia perder a oportunidade extraordinária que esta mesma representa à pesquisa como registro e reflexão. Inside out, outside in . O perigo de fazer juízos recheados de preconceito próprios de quem não é de lá e não sabe o que acontece é uma constante nos relatos, mas parece, ao mesmo tempo, ser uma forma franca e capaz de comunicar, a quem porventura for lê-los, a dificuldade de estudar tema tão complexo e amplo em termos históricos. Estávamos a observar as superfícies da circulação nas quais aparecem as representações subjetivas da armenidade.

\footnotetext{
2 Problematizamos esta questão especialmente nos itens da segunda parte “o boom de 1914” e “ Mobilização geral e extermínio como acumulação de capital na formação nacional da Turquia”.

3 Essa possibilidade de visitar Armênia enquanto voluntário através do programa internacional BirthRight Armenia, voltado aos descendentes da diáspora armênia, permitiu a realização do trabalho de campo tematizado na segunda parte da Dissertação, pois após 14 semanas de trabalho voluntário minha passagem foi paga pelo programa.
} 
Tentamos expor os relatos de campo referentes ao período vivido na Armênia de maneira que eles puxassem os temas a serem problematizados pela revisão bibliográfica. Em relação aos problemas vistos no cotidiano do pesquisador-imigrante, a ordem da exposição nos fez elaborar reflexões sobre a Questão Armênia ao longo do século XIX em uma abordagem com intuito de pensar o problema da formação do Estado nacional dentro dos territórios do Império Otomano. Seguimos a cronologia para tratar da Primeira Guerra Mundial (1914-18) e o Genocídio Armênio como plano de extermínio em execução, um “assunto interno” do Império durante esse período de guerra. A leitura de Taner Akçam (2010) foi fundamental para encorpar a hipótese do Genocídio como parte de uma acumulação de capitais, ou ao menos de uma centralização de capitais na formação do Estado nacional turco frente à dissolução do Império Otomano durante a guerra 1914. Os itens que tratam disso não partem de um relato de campo, mas tratam também sobre o problema do imperialismo às voltas com uma leitura de Lenin, abordando o imperialismo no contexto do início do século XX e das mudanças históricas que o imperialismo, enquanto fenômeno político, vem atravessando desde a revolução microeletrônica dos anos 1970 e cuja compreensão se fez junto da leitura de Kurz (2003 e 1997b).

A experiência de trabalho voluntário é bastante presente nos relatos de Gyumri, mas também nos de Yerevan - especialmente naqueles sobre a Biblioteca Nacional da Armênia e sobre algumas das minhas atividades como professor de Geografia. Os relatos referentes à cidade de Shushi, ambientados em zona de guerra, trazem reflexões acerca da guerra de Nagorno-Karabagh a partir de fala de especialistas, políticos e observações naquele tempo e espaço. Em meio a essa zona de guerra tentamos estabelecer conexões com a discussão da acumulação primitiva e a produção do espaço ao elaborar uma reflexão que fosse crítica à ideia de que a acumulação primitiva se repõe infinitamente, e isso a partir da leitura de Scholz (2016), o que aparece brevemente nessa parte e de maneira mais detalhada no último relato da segunda parte. Neste relato que encerra a viagem à Armênia, tratamos ainda da “questão da mulher” e nesse ponto destacamos o papel de nossa companheira de viagem, Marina, que muito nos informou sobre o problema. Novamente o argumento desenvolvido por Scholz (2016) muito nos ajudou para traçar relação entre acumulação de capitais, que parecem se repor sobre os outsiders implicados nos problemas da dissociação particularmente armênios.

Por fim, interessa dizer que em várias passagens a contraposição entre as armenidades hayastantsi e spyurqhay foi tematizada, como já na primeira parte e especialmente na parte segunda. Essa contraposição se manifesta através, entre outros fenômenos, da identidade tendo o Genocídio como mito fundador (Porto, 2017) para os spyurqhay e através do ethos de guerra de Nagorno-Karabakh como forte elemento da identidade aos hayastantsi. Esses temas, entre outros, 
vieram à tona por conta de viagens ao interior da Armênia e das conversas ali, no meio da rua. Mas felizmente, mesmo dentro (in) foi possível estabelecer articulações com os de fora (out), como no caso da relação com a Rússia, com as outras fronteiras do país, além das questões sobre o colapso da modernização (Kurz, 1992) e Armênia pós-soviética.

Essa contradição apontada ao longo das reflexões propostas neste texto foi de grande importância para se pensar as diferentes identidades em relação, mas restringir-se a essa contradição não dá conta do problema. Não basta observar os fenômenos empíricos, é preciso trilhar o caminho da crítica sem perder de vista a contradição fundamental do capital no processo de valorização do valor. 
PARTE UM - Refugiados fazendo a América 


\section{1) Presidente Altino, 15 de dezembro de 2015}

O projeto de pesquisa foi vendido com uma pergunta mais ou menos assim: é possível observar uma territorialidade armênia no distrito de Presidente Altino?

Um pesquisador senta-se num restaurante em frente à Avenida Henry Ford. Almoça para fugir do calor dos trinta e vários graus. Só há homens consumindo. Prato feito R\$ 11,00. Garrafa $300 \mathrm{ml}$ de Skol a R\$ 3,50. A televisão exibe “Casos de família”.

Quando o trem passa pela Marginal Pinheiros o pesquisador vê barracos de madeira em barrancos íngremes, movediços, dos dois lados, mas principalmente à margem direita do trilho. A territorialização da autoconstrução de madeirite passa, mais a frente, à do bloco laranja sem reboco. No mundo das ações controladas por robôs, das bolhas de crédito, da securitização irreal de produtos que sequer existem, da alavancagem como método de gestão do capital, da crise como tragédia e farsa, da fibra ótica, hardware e software valendo mais do que qualquer coisa: quem acessa esse dinheiro todo? Onde vivem os não-rentáveis, os supérfluos, os apátridas, os imigrantes? Se o subúrbio da década de 1920 e 1930 era só um distrito afastado e rural, hoje ela se mostra periferia para as mercadorias em trânsito dentro de um trem, o colapso da metrópole nas formas de moradia.

- O Brasil já era, diz a funcionária do restaurante.

- Você acha que ela (Presidenta Dilma Rousseff) vai sair? - Indaga um cliente.

- Acho, o povo que votou nela tá revoltado. Eu não votei.

Ela limpa o chão enquanto o pesquisador levanta os pés, absorto no que escreve.

- Tá estudando, moço? Pergunta a funcionária.

Meio sem jeito, responde o pesquisador:

- É, tô escrevendo umas coisas. É que eu faço uma pesquisa na faculdade...

- Pesquisa do quê?

- Sobre os armênios que vieram pra cá na década de 1920 e 1930. Você conhece alguém? - Ele pergunta na esperança de um surpreendente “achado”.

- Não, mas já ouvi falar... essas coisas de guerra?

- Sim.

- Você conhece o Altair da Padaria, vereador?

- Não, conheço bem pouco daqui, responde o pesquisador.

- Ele sabe bastante dessas coisas, é um velho que mora aqui faz muitos anos. Você tem que procurar as pessoas mais velhas. 
- Você mora aqui?

- Sim, mas não sei dessas estórias.

Ela segue seu trabalho, limpa a área com pano de chão umedecido em produtos de limpeza. Recolhe cadeiras, fala com sua colega por uma janela que dá para a cozinha do estabelecimento. Afixado à esquerda da mesa do pesquisador um papel escrito: "Por 3,00 motivo vamos cobra o disperdício”.

O calor continua castigando. Minutos depois o pesquisador pede outra cerveja.

O dono do restaurante, na saída, diz ao pesquisador que os armênios "são meio chatos, muito fechados entre eles". 


\subsection{Migração e trabalho. Diáspora e cultura}

A noção de diáspora armênia que é usualmente difundida (SAPSEZIAN, 1988; FREITAS, 2001) baseia-se nas estratégias de reprodução que as comunidades armênias usam e usaram para se estabelecer e se afirmar, através da armenidade, como grupo distinto nos países de destino dos refugiados do genocídio. É, portanto, uma noção que enfatiza os elementos culturais característicos, notadamente língua e religião, assim como as instituições que se encarregam de manter a organização das comunidades diaspóricas, como igrejas, partidos políticos, sociedades beneméritas e clubes.

Nesse ponto, Pedro Bogossian Porto entende que as instituições armênias são fator crucial para a organização e reprodução dessas comunidades que constituem a diáspora.

(...) grande parte da relevância que a Igreja Apostólica Armênia assume perante a comunidade, por exemplo, está ancorada na função milenarmente exercida pela instituição na manutenção da coesão da coletividade, pois mesmo a ideia de "nação armênia” não se justifica sem que se refira às suas origens e aos seus símbolos históricos, dentre os quais a Igreja é peça central. Nesse sentido, a população armênia deve ser entendida como uma comunidade imaginada, resultado de uma abstração que, baseada em elementos concretos, produz uma identificação entre indivíduos que, de outro modo, jamais se perceberiam como parte de uma mesma coletividade. (PORTO, 2011: 7)

Nesse sentido, a noção de Nação é compreendida por Porto como uma construção abstrata a posteriori, na qual a escolha de elementos de legitimação de um determinado projeto nacional, como as semelhanças entendidas como culturais, linguísticas, atendem à assim chamada população armênia que vem se afirmando enquanto uma comunidade imaginada ${ }^{4}$.

De acordo com Sapsezian, são dois os fatores que explicam a

(...) proverbial índole peregrina dos armênios. O primeiro, mais determinante, são as adversidades sofridas em sua terra natal, encruzilhada das ambições de outros povos; o outro fator é o espírito

4Benedict Anderson, Comunidades Imaginadas. São Paulo. Companhia das Letras, 2009 [1983]. No primeiro capítulo do livro Nações e Nacionalismos desde 1780, “A nação como novidade: da revolução ao liberalismo”, e também na introdução, Hobsbawm inicia como é comum em muitos trabalhos, tentando conceituar as palavras/ verbetes que serão centrais na construção da análise que o autor pretende empregar. No caso, os conceitos problematizados de início são: nação, Estado e língua. Através de alguns exemplos o historiador demonstra que os conceitos a serem trabalhados, em especial o de "nação" e o de "nacionalidade” são frágeis por dois motivos que se destacam. Primeiro, que a construção feita pelos teóricos nacionalistas é em grande parte contraditória com o que acabou acontecendo. Em segundo lugar, é apontado como erro o entendimento de uma nação apenas por um único elemento, seja ele cultural, político, econômico ou qualquer outro. O autor acaba por definir nação de maneira bastante generalista: corpo de pessoas suficientemente grande cujos membros consideram-se como membros de uma nação (p.18). O período que se construiu as idéias nacionalistas (de 1780 até meados do século posterior) é marcado pela forte influência do pensamento liberal, o que leva o autor a escrever sobre "princípio da nacionalidade", uma aplicação das idéias liberais ao conceito de nacionalidade. Seguindo essa idéia, a formação de uma nação ocorreria de maneira mais ou menos espontânea e, a partir do momento que um grupo mais ou menos coeso em um determinado espaço entende que é necessária uma organização dessa unidade, aos poucos isto acabaria por acontecer e assim formar uma nação. Outro verbete usado ao longo de todo o texto é o de “Comunidades imaginárias”, que só por sua filologia já demonstra que teorização dos nacionalistas é referente a uma série de símbolos criados para construir a imagem, cultura e sentimento de nacionalidade com as quais os integrantes de uma determinada nação devem acreditar, partilhar ou ter como referência. Essas construções são assimiladas pela população, que posteriormente a toda essa construção teórica acaba por ser o corpo dos movimentos nacionalistas na Europa no final do século XIX. (Hobsbawn, 1990) 
empreendedor, o gosto pela aventura e pela descoberta próprio de inveterados andarilhos (SAPSEZIAN, 1988: 159-160)

Essa afirmação do autor é flagrante no sentido de naturalizar “o gosto pela aventura” como característica própria aos armênios, ainda que mais adiante no seu texto haja uma diferenciação qualitativa da diáspora recente, referente aos massacres hamidianos e ao genocídio na Primeira Guerra. Essa distinção é bastante importante e atribui a esses eventos violentos o que ele entende por conteúdo psicológico dessa diáspora:

Esta não é uma diáspora de emigrantes econômicos, no sentido de grupos que abandonaram seu país movidos pelo desejo de encontrar espaço de liberdade e de trabalho, mas de refugiados, sobreviventes de um naufrágio, milagrosos escapados da hecatombe... (Sapsezian, 1988: 160)

Essa caracterização da grande diáspora armênia $^{5}$ tem grande importância para se pensar a particularidade da migração armênia. A qualidade de refugiados de um extermínio em massa, pogrom, diferencia muito a mobilização dos armênios em um momento de reordenamento das relações de produção, envolvendo grandes mobilizações, migrações que redefiniram decisivamente o mapa da Europa na forma de modernização ultra violenta que foi a Primeira Guerra.

No entanto, a particularidade do momento histórico que faz dos armênios refugiados do genocídio não tira destes, diferente da interpretação de Sapsezian, sua qualidade de "emigrantes econômicos”. A partir da abordagem que o conceito de mobilidade do trabalho ${ }^{6}$ (Gaudemar, 1977) permite, podemos extrapolar essa perspectiva cultural e pensar nos armênios não só como aqueles que reproduzem a ideia de etnia, comunidade, e que de fato se organizam a partir de suas instituições; mas também, pensar a diáspora como fenômeno possível somente na sociedade moderna em que a forma mercadoria se generalizou como fundamento da sociabilidade.

A mobilidade do trabalho visa compreender a particularidade da migração na modernidade, na sociedade produtora de mercadorias (Kurz, 1992). Nesta sociedade em que a socialização se dá através da equiparação de trabalhos diferentes para a troca, comparados unicamente pelo critério

5 Vale ressaltar que Sapsezian inicia seu capítulo sobre a diáspora armênia fazendo um apanhado dos destinos de exílio ao longo de um tempo trans-histórico, períodos que abrangem do século $\mathrm{X}$ até a diáspora da história recente.

6 O conceito de mobilidade do trabalho leva um capítulo para ser desenvolvido e um livro para dar conta de sua relação com a acumulação de capital. Não vamos, obviamente, expor a complexidade do argumento, mas parece importante retomar o item mobilidade do trabalho do quinto capítulo, por sua forma sintética ao articular termos, conceitos, categorias da crítica da economia política d'O capital; sobre forma valor e o trabalho abstrato na passagem fantasmagórica da relação social entre coisas:

Esta progressão da forma-valor pode precisamente compreender-se pelo recurso à mercadoria-força de trabalho. Ela permite muito mais facilmente, pela sua identificação, esta 'redução de todos os trabalhos' a um dispêndio de força humana; na sua forma capitalista, o trabalho não é mais do que 'o uso ou emprego da força de trabalho'. Ele é portanto uso de uma mercadoria ou ainda troca de uma mercadoria (força de trabalho) por outras mercadorias (produtos). Perde assim a aparência de 'uma relação social dos homens entre si' para tomar 'a forma fantástica de uma relação de coisas entre si’, já que, na relação social dos homens entre si, que representa o emprego da força de trabalho, a força de trabalho coloca-se nas coisas, torna-se coisa entre as coisas, mercadoria entre mercadorias (Gaudemar, 1977: 198) 
quantitativo de tempo social médio de trabalho, o chamado trabalho abstrato (Marx, 1985); nesta sociedade que se impõe, migrar é mobilizar trabalho para acumulação do capital (Gaudemar, 1977). Desta forma, o que possibilita uma pessoa ir de um lugar a outro, migrar, é o fato de que na sociedade em que a mercadoria ocupou totalmente a vida social (Debord, 1997), a mercadoria força de trabalho tem mobilidade para se vender em qualquer lugar, tanto na ilusão de sujeito que escolhe onde trabalhar (liberdade positiva) como para um refugiado que não sabe onde vai aportar o navio (liberdade negativa, ou menos do que isso).

Para transformar dinheiro em capital, o possuidor de dinheiro precisa encontrar, portanto, o
trabalhador livre no mercado de mercadorias, livre no duplo sentido de que ele dispõe, como
pessoa livre, de sua força de trabalho como sua mercadoria, e de que ele, por outro lado, não tem
outras mercadorias para vender, solto e solteiro, livre de todas as coisas necessárias à realização de
sua força de trabalho.
A questão do por que esse trabalhador livre se defronta com ele na esfera da circulação não
interessa ao possuidor de dinheiro, que encontra o mercado de trabalho como uma divisão
específica do mercado de mercadorias. E tampouco ela nos interessa por enquanto. Nós nos
ateremos ao fato na teoria assim como o possuidor de dinheiro na prática. Uma coisa, no entanto, é
clara. A Natureza não produz de um lado possuidores de dinheiro e de mercadorias e, do outro,
meros possuidores das próprias forças de trabalho. Essa relação não faz parte da história natural
nem tampouco é social, comum a todos os períodos históricos. Ela mesma é evidentemente o
resultado de um desenvolvimento histórico anterior, o produto de muitas revoluções econômicas,
da decadência de toda uma série de formações mais antigas da produção social (Marx, 1985, I, t. 1,
cap. 3: 140)

Essa passagem tão cara ao argumento que Gaudemar desenvolve sobre a mobilidade do trabalho ajuda a pensar no caráter histórico da força de trabalho, como próprio da relação-capital que dá forma à sociedade produtora de mercadorias. O desdobramento desse argumento seria o da demonstração histórica do que foi a acumulação primitiva, momento de separação entre produtor e meios de produção (Marx, 1985, I, t. 2, cap. 24, 262).

A diáspora armênia, para além da reprodução cultural armênia, pode ser entendida como a forma particular de inserção dos armênios nos países de destino dos refugiados da guerra de 1914. Para Gaudemar, a circulação das forças de trabalho, a mobilização das pessoas pelo trabalho para acumulação do capital, é um momento de submissão ao mercado que desloca os trabalhadores de uma esfera à outra. A mercadoria força de trabalho tem na sua mobilidade “a capacidade que permite à força de trabalho adaptar-se às variações da jornada de trabalho, à permutação dos postos de trabalho, aos efeitos de uma divisão do trabalho cada vez maior (GAUDEMAR, 1977: 194)”.

No entanto, são muitos os fatores que diferem esse momento histórico em que o extermínio planejado por um Estado se coloca como possibilidade.

Cabe pensar quais são as particularidades da migração armênia para São Paulo, tendo como base o fato de que as relações mercantis já estavam generalizadas, possibilitando, portanto, a venda da força de trabalho dos armênios no Brasil, sua mobilidade. 


\section{3) Entrevista com Armênio Burbulhan}

Essa é a primeira entrevista dentre três grandes entrevistas que optamos uma forma de exposição inspirada em um livro de Bertold Brecht chamado “Conversas de refugiados” em que o dramaturgo alemão explora diálogos entre dois alemães refugiados em Helsinque, Finlândia durante a Segunda Guerra Mundial. Um deles é Ziffel, um físico e o operário Kalle. Os conversam sobre assuntos variados e o autor marca cada parte com pequenos títulos que dão pistas sobre o desenvolvimento da conversa.

Armênio Burbulhan nos cedeu essa entrevista em sua casa no dia 31 de março de 2013, seus depoimentos contam sobre a trajetórias de migração e mobilização do trabalho, história de sua família em Presidente Altino e trazem importantes informações sobre seu pai que foi o Presidente do Sindicato dos Calçados do Estado de São Paulo durante muitos anos. Seu depoimento ajuda a entendermos a dinâmica da personificação dos armênios de São Paulo em sua proximidade à indústria calçadista, assunto que trataremos ao longo desta parte primeira.

\section{I) Caminhos diferentes/ Empresa familiar, calçados dos maridos}

(Armênio Burbulhan) - Tiveram caminhos diferentes, né? Tanto da parte dos meus avós paternos quanto...vieram de lugares diferentes. O meu avó paterno, por exemplo, ele foi chefe de cozinha na França, depois de ter saído da Armênia, atual Turquia. Ele saiu da Armênia naquela época por causa da guerra mesmo e foi trabalhar na França como chefe de cozinha, chefe de cozinha de hotel. Hotel assim, comida internacional, essas coisas. Eu cheguei a conhecê-lo, até os cinco, seis anos de idade, depois ele faleceu. A mulher dele eu não conheci, mas ela era bem conhecida no lugar onde ele morava, lá em Osasco. Meus pais, meu pai, veio de Presidente Altino. Então quando eles mudaram pra cá eles acabaram morando em Presidente Altino. Não era nem Osasco, na época era bem dividido, hoje você fala Presidente Altino você lembra de Osasco. E a colônia armênia era grande lá, meus padrinhos são de lá. Tem um núcleo bem grande ainda hoje de armênios na região.

(Artur) - E você sabe a região lá do Império onde eles estavam? A cidade?

(Armênio Burbulhan) - Sei, minha mãe, a família dela, a mãe da minha mãe é de Marash, Marachá, né? Tiblisi, Tiblisi, meu vô era de Tiblisi, vô paterno. Eu falo deles porque eu peguei só dois avós vivos. Um por parte do meu pai, que é o pai do meu pai e a mãe da minha mãe. Esse é o conhecimento que a gente tem. Essa mãe da minha mãe veio de Marash, mas assim, eu acho que 
teve os dois primeiros filhos lá, mais velhos, dois homens e a minha mãe, mais a irmã mais nova nasceram no Brasil. Quando a gente fala de imigração, parte da imigração já é nata do Brasil, nasceu aqui mesmo. A primeira pergunta quando falo que sou armênio: "seus pais são armênios?” Não, já tem uma geração a mais. De profissão mesmo, acredito que meu avó o resto (do tempo em que viveu) no Brasil não sei se ele chegou a trabalhar não.

(Artur) - E na França onde era que ele trabalhava? Em que cidade, você lembra?

(Armênio Burbulhan) - Não vou saber te dizer...

(Artur) - Muitos foram pra Marselha, não é?

(Armênio Burbulhan) - Nossa, os tios da Cláudia (esposa) ainda estão lá, a gente foi lá conhecêlos. Porque na verdade Paris não era capital naquela época, né? Acho que era Marselha era capital da França.

(Artur) - Ou era o acesso de navio...

(Armênio Burbulhan) - Do Mar Mediterrâneo, também. É, mais próximo do Mediterrâneo, também tem essa. Independente de tudo, eles vieram pro Brasil. Meu avô, por parte de pai, ele casou na Armênia, né? Mas teve essa guerra e ele perdeu duas esposas na guerra. Ele casou, de novo, a outra mulher foi morta também, aí ele veio pro Brasil e casou acho que aqui, o pai do meu pai. Mas a gente nunca soube de familiares de lá, parece que não rendeu muitos frutos. E aí, no Brasil, meu avô teve meu pai, mais uma filha. Como meu pai casou e minha tia também casou, eles fizeram uma sociedade. Já eram consanguíneos, tinham essa ligação consanguínea e fizeram uma ligação, uma sociedade pra montar uma fábrica de calçados. Lógico, os maridos né? Porque as mulheres não contavam naquela época. Então, meu pai e o marido da minha tia, que também era armênio. Ele era contador, então ele ficava fazendo essa parte de contável na empresa e meu pai era super-social. Toda essa parte de conhecimento social, o grande piadista, toda pessoa que é bem comunicativa, não é? Então ele teve várias ligações com a sociedade armênia, por exemplo, na Escola Armênia ele foi diretor, Presidente lá da SAMA ainda quando era lá em Presidente Altino. E ligado, também naquela época ele era jovem e ligado à juventude armênia, então eu acho que teve todo esse desenvolvimento. Junto às sociedades tinha que ter alguém que...então ele sempre se candidatou pra todas essas...então você vai ver, sabe, parece que a profissão dele era ser presidente de alguma coisa. Inclusive na escola, na faculdade que ele fez ele foi presidente do grupo de alunos, né? Era Sociologia Política. Você quer perguntar mais alguma coisa?

(Artur) - Nesse começo, quando eles começaram? Se eles contaram com a ajuda de outros armênios pra começar a fábrica deles? 


\section{II) Costume armênio e acumulação de capitais no subúrbio}

(Armênio Burbulhan) - Tá, essa história dos meus pais eu falei que são bem diferentes, né? A minha mãe ela veio morar num cortiço, cortiço de armênios na época. A conotação de cortiço na época acho que era mais diferente do que é hoje, era cortiço familiar, então você tinha famílias morando em quartos diferentes em uma casa. Cada quarto morava uma família, então a família do lado minha mãe chamava de tios, não é? Naquela época mesmo que não fosse sanguíneo, essa história de um ajudar o outro, não é? E o lado da minha mãe, eram quatro irmãos, que nem eu te falei, dois nascidos lá e duas nascidas aqui. Então foi uma coisa difícil pra elas, ela conta uma história sempre que ela conseguiu entrar numa escola grátis, uma escola que não pagava, né? Mas minha falava assim: "não tem dinheiro pro bonde”, quer dizer a dificuldade era essa, não era nem pagar escola, não tinha condução, né? Minha morou, nasceu lá no (na Rua do) Gasômetro, naquela região. Já meu pai, eu acho que também passaram uma certa dificuldade, meus avós principalmente, mas por costume armênio tem aquele negócio de ler xícara, já ouviu falar isso? (Artur) - Já...

(Armênio Burbulhan) - Minha avó lia xícaras, não é? E como começou a se difundir isso na região, vinha até políticos de outras regiões pra: “aí eu vou ser candidato, será que eu vou ganhar, será que não sei o quê?”. Então, minha avó começou a ser conhecida "a turca da sorte”, que lia xícaras, tal. E ela fez um certo patrimônio, não é? É a coisa mais esquisita que pode se contar. Essa senhora, essa minha avó ela quando saiu da Armênia, tinha família. Ela e a irmã dela foram colocadas num paredão, no genocídio, né? E foram metralhadas e depois foram jogadas na vala comum. Da vala comum, minha avó se reanimou, ela recebeu uma bala no couro cabeludo, né? Então ela desmaiou, não morreu, mas a irmã morreu, os parentes, todo mundo lá ficou na vala comum. Ela fugiu da vala comum e fez esse caminho que estou te contando. Ela chegando em São Paulo, chegou no Brasil...sabe, ela fez o que ela sabia fazer, ler sorte, não é? Deu muita sorte pra ela na verdade, ela trazia uma mensagem, sempre a sorte você nunca fala uma coisa, lê a xícara, você nunca fala: “você vai morrer amanhã”. Ninguém vai voltar, então sempre falava alguma coisa de boa sorte pras pessoas. E ela fez isso, fez isso por um bom tempo, que nem eu te falei, juntou um patrimônio até que, lá em Osasco, meus pais era os primeiros a ter pouca coisa elétrica, né? Assim, ter a primeira televisão do bairro, o primeiro carro importado, coisas assim que o contraponto da minha mãe, não tinha condição, tudo era andar a pé. Então eu acho que é assim, dinheiro pra montar a empresa foi a minha avó que cedeu pra eles, a ajuda veio da minha avó, né? É lógico que, a minha mãe sempre conta histórias de que famílias ajudavam famílias naquela 
época, tal. E acho que funcionou muito bem com a minha mãe isso. Tias que ajudavam, primos, a família era sempre numerosa, né?Não digo a dela, mas outras. Então sempre tinha convivência por causa de morar na mesma casa, não eram parentes consanguíneos, que nem eu te falei. A família da minha mãe hoje é grande mas não é... ela tem mais a parte conhecida, ela tem mais a parte de conhecidos. Porque minha mãe e meu pai foram muito sociáveis, iam em todas as festas. Eu percebi uma coisa quando eu casei, não é? Veio uma quantidade enorme de pessoas que eu não conhecia. Mas imensas, pessoas que... Ele me explicou: "olha filho, eu to dando essa festa porque você foi o primeiro a casar. Então ele deu uma festa no Hotel Nacional na época e convidou, acho, 700 pessoas, 350 da família da Cláudia, 350 da minha família que era um agradecimento por eles terem convidado meus pais pra casamento dos filhos, tal, tal, tal...Então, em retribuição a vários casamentos, várias festas, partes sociais, ele fez essa festa de agradecimento pro resto da sociedade também. Não é que ele não conhecia ninguém, uma grande parte era do trabalho dele... Então que é assim: em Osasco, lá em Presidente Altino, eles conseguiram um bom status de vida. Meu pai logo que...você quer que fale mais do meu pai?

\section{(III) Profissão: presidente}

(Artur) - Pode ficar à vontade...

(Armênio Burbulhan) - Ele veio pra São Paulo, veio morar aqui no centro, 16, 18 anos. Ele veio morar na avenida São João, em um hotel. Não é que comprou uma casa nem nada. Então a vida dele mais foi ligada ao centro de São Paulo já. Tem um belvedere na São João que tinha alguns hotéis e tal e ele ficou por ali. Perto da Praça da República, aquela região. Acho que ele já veio com a ideia de ficar, de que depois que montasse a fábrica de calçado e, lógico, com um pouco mais de dinheiro ele iria comprar uma casa aqui em São Paulo. Acho que era essa a visão dele, não voltar mais pra Presidente Altino. E minha mãe já estava em São Paulo, ela participava muito do coral armênio, coral, todos os mais ricos, achava legal isso que não tinha distinção naquela época, né? No coral cantava todos, só bastava ter voz e querer cantar. Então ela participava dessa parte do coral e meu pai com essa parte de administrativo, de ser presidente das associações, quando ele saiu de Osasco que ele era Presidente da SAMA, Sociedade Artísticas Melodias Armênias, diz ele que ele que bolou a sigla, né? É, história dele. E quando veio pra cá também foi presidente do que foi o futuro Clube Armênio. A SAMA da (avenida) Tiradentes.

(Artur) - Ah, tá. Porque hoje é em Moema, né?

(Armênio Burbulhan) - Ah sim, é na (rua) Ascendino Reis, é o Clube. Mas assim, antigamente só existia a Escola que era na (avenida) Tiradentes e a Igreja na frente, no mesmo terreno. Eu estudei 
lá na Escola, fiz o primário lá. Ele chegou a ser, na época que eu estudei na Escola Armênia Externato José Bonifácio, ele foi Diretor da Escola e já era Presidente da SAMA lá. Como a Escola andava meio mal das pernas, tal, tinha que chamar mais alunos armênios pra vir, então ele se propôs a ser Diretor, uma espécie de marketing pra chamar mais indivíduos da sociedade armênia pra colocar os filhos lá, né? Porque ele colocou os três filhos, na época só tinha o primário. Deixa eu explicar isso aqui: eu fiz até o primário na Escola Armênia, minha esposa por exemplo, ela acabou o ginásio lá, porque já eram anos depois de eu ter terminado, ter passado por lá, a Escola foi crescendo, né? Então ele foi Diretor da Escola Armênia. Não sei eu fica constrangido quando ele entrava em sala de aula, sabe aquela coisa "o filho do Diretor", sabe essas coisas? Eu fui muito tímido na verdade e me atrapalhava demais essas relações e contrário do meu pai; meu pai todo mundo conhecia ele, era engraçado você andar na rua, ele tinha que, na saída da Igreja por exemplo, ele ficava de cinco em cinco minutos sendo chamado pra conversar com alguém, lembrar do passado, coisas assim. E a gente não, a gente, eu não sei dos meus irmãos, eu tenho um irmão mais velho e um irmão mais novo. Acredito que naquela época tudo, a educação era o filho mais velho, né? Até quando me pediram para falar um pouco sobre meu pai, falei assim "a pessoa mais indicada é meu irmão mais velho", mas minha falou "não, tudo igual, sabe? O que ele sabe você sabe também.” Eu sei assim, que nem tô te falando, não sei datas, né?

Tava vendo uma coisa assim, ele montou uma fábrica de calçados em 1945. Ele nasceu em 1924, ele montou essa fábrica em 1945 e ele era dado a fazer esses negócios, a SAMA, e aí ele fez Tebas que era Tervanda e Bas de Bastião, Sebastião. E essa fábrica que foi meio sociedade da minha tia com meu tio e meio sociedade com minha mãe e meu pai que eram os donos da fábrica. Eu quando nasci, ele falava "quando for pra colocar na carteira da escola, pra você assinar, se alguém perguntar você fala que eu sou industrial”. Então eu sempre soube assim, pra mim ele falava eu sou industrial. Então sempre quando perguntavam "o que que seu pai faz”? Industrial. Isso eu aprendi. Outra coisa que, desde meus primórdios, acho que foi em 1955 mesmo, o ano que eu nasci que ele foi chamado pra ser o Presidente do Sindicato de Calçados, uma coisa que também, como te falei, de 1945 a 1955 foram dez anos de fábrica de calçado e pra você ser presidente de sindicato, você não pode ser se você não tiver uma fábrica de calçados. Então tudo isso, uma coisa vai chamando outra. Meu pai foi levando a vida assim crescendo, a fábrica cresceu aí fechou porque acho que por causa do metrô. O metrô ia passar e muita gente com essa estória parecida de o lugar onde a fábrica está ser desapropriado.

Artur: Isso foi quando? 
Armênio: Olha, foi na época do metrô mesmo.

Artur: Linha azul?

Armênio: É a primeira linha ainda, a azul, não tinha outra ainda. Foi, não dizer, foi em 1975, 1976 alguma coisa assim ${ }^{7}$. Mas até lá eu vou te explicar uma coisa: quando fechou a fábrica se ele não tivesse uma outra fábrica, se ele não continuasse sendo dono de fábrica ele teria que sair do sindicato, e meu pai foi eleito ano após ano, por que? Duas coisas, dois fatores importantes nesse caso de meu pai ser eleito como presidente do sindicato, né? É uma bucha que ninguém queria segurar. Uma bucha assim...muitos problemas e ninguém queria segurar. Então é assim, não tinha outro cara que se elegesse, não tinha outro candidato para derrubar meu pai e meu pai meio que se elegia por maioria sempre, né? Isso é um motivo, né? E outro motivo é esse negócio dele se dar bem sempre, ele tinha uma ligação com todas as pessoas. Você sendo presidente do sindicato dos calçados você conhecia toda sociedade armênia e toda sociedade armênia tinha fábrica de calçados, né? Então era uma ligação interessante para o sindicato ter uma pessoa que tivesse contato com todos os fabricantes de calçado e ao mesmo tempo isso que eu falei, uma coisa que ele resolve. Ele chega no lugar e resolve, não é uma coisa que fica patinando. Ele era muito bom de dar entrevista, eu lembro do meu pai dando entrevista assim Folha de São Paulo, Estado de São Paulo em jornais, tem o Diário do Comércio que é uma coisa que eu lembro, fora TV, Rádio e essas coisas que era direto em casa. Às vezes nós como crianças não gostávamos muito "vai ficar lá pra dentro, lá pra dentro”, mas tinha esse assédio com meu pai, né? Um assédio benéfico em relação ao trabalho que ele executava. Eles fundaram a Feira de Calçados, na época tinha muita coisa de feira, feira de Utilidades Domésticas, das Crianças e tinha feira dos calçados e dentro da feira, eu achava fantástico, meu pai tinha um stand lá dentro que não era dele, né? Lógico que não, era do Sindicato. Então tinha todos os fabricantes na época, marcas de calçados hoje não se ouve nem falar que eram grandes na época. Meu pai, ele foi crescendo com outras sociedades. Era interessante para uma fábrica de calçado ter o meu pai como sócio, sócio do Presidenta do Sindicato de Calçados. Então essa troca, essa simbiose que eu falo entre, simbiose de interesses, entre proprietário de uma fábrica de calçados e esse lugar social que meu pai se colocou. Ele viajava muito para Franca, viajava muito para o Rio Grande do Sul, nos focos de onde crescia os calçados.

Artur: Birigui?

7a Linha 1 do Metrô de São Paulo começou a ser construída em 14 de dezembro de 1968. Sua operação comercial começou no dia 14 de setembro de 1974. 
Armênio: Birigui não era forte na época, é agora. Mas se falasse Franca, Franca era, eu não lembro do Rio Grande do Sul qual que era a cidade que produzia, mas assim era uma coisa fenomenal, era o pólo São Paulo capital, Franca e uma cidade do RS que me fugiu à memória.

\section{IV) Modernização/ Invasão chinesa e caminho para o colapso da armenidade calçadista}

Artur: E ele pegou o momento que São Paulo foi enfraquecendo como pólo de indústria calçadista?

Armênio: É, antes de isso acontecer, uma coisa aconteceu de interessante. Meu pai viajava muito pro exterior para resolver, ele foi convidado, pelo cargo do Sindicato, a FIESP convidou meu pai para ser Vice-Presidente de lá. Então tinha cargos interessantes que precisava: Importação e Exportação, Indústria e Comércio, ele fazia essa ligação. Então na época, um dos sócios do meu pai, meu pai foi sócio da Alpargatas, né? Porque a Alpargatas queria exportar umas máquinas injetoras que na época eram muito famosas, grandes tal e tal..e meu pai tinha duas coisas interessantes para ele. Mexia com importação e exportação na FIESP e era Presidente do Sindicato dos Calçados. Então voltou essa coisa de simbiose com outro tipo de relacionamento e então ele foi Diretor da Alpargatas, eu fico imaginando que é uma coisa muito interessante, naquela época ainda o calçado tava em alta.

Artur: Isso quando mais ou menos?

Armênio: Olha, eu acredito que 1980, 1982 que foi a época que eu casei. E tem uma coisa interessante, como ele viajava muito, vamos supor essas máquinas injetoras que eu tô falando ele via alguma coisa na Rússia ele falava "nossa eles estão tão avançados" e então ele vinha contava coisas de computador que não existia aqui no Brasil, não era PC ainda era computador de indústria.

Cláudia (esposa do entrevistado): Tem uma coisa, eu tô ouvindo a conversa de vocês, uma das coisas que acho que é importante, pelo menos é que mais fica da época que seu pai trabalhava com isso é o quanto ele protegeu e defendeu a indústria brasileira na época da ameaça da invasão chinesa que hoje tudo isso aqui é chinês. Mas assim, só fica como interferência.

[Cláudia se despede nós e me deseja boa sorte]

Armênio: Eu acho que eu vou chegar nesse ponto também é outro fator de ele estar tantos anos seguidos no Sindicato de Calçados e que as pessoas viam nele um protetor do mercado interno. 
Acho que isso é uma coisa bem consciente. Teve uma época que um dos sucessores do meu pai nessa Feira de Calçados foi um tal Francisco que era do Rio Grande do Sul.

Cláudia diz ao fundo: Francisco era da Couro Modas.

Armênio: Couro Modas, né?

Cláudia diz ao fundo: Era a época que a Constituição obrigava o sindicato ter uma presença na organização das feiras se não, não podia ter feira.

Armênio: Isso.

Cláudia: Aí depois da Constituição de 1988 isso aí caiu.

Armênio: Então, teve essa migração, essa abertura para mercado exterior, né? Na verdade, como houve no calçado, houve no tecido, eu fui para Sorocaba um dia ver as fábricas. Existe uma situação em Sorocaba de fábricas e fábricas, enormes, quarteirões, sabe coisas construídas com muita grana, né? Fechado. Assim, você chega tá o pateo crescendo capim, alguns já destelhados e isso era de tecidos, né? Porque houve essa invasão do mercado chinês de tecidos que era muito mais barato, mão de obra deles era a gente costuma falar que é uma coisa escrava lá, que não se paga uma remuneração devida, por isso que é incompetitível na verdade. Você não consegue competir se você não paga algum funcionário para fazer alguma coisa. O preço do dólar brasileiro é superior a qualquer coisa que se pague na China, com tantos milhões de habitantes de lá. Era previsível que isso ia acontecer, a queda de calçados, mas começou a cair e meu pai deu uma desligada. Aos poucos ele foi entregando cargos, passando para pessoas que ele achava que trabalhavam junto com ele também. 


\section{4) Suburbana armenidade}

"Vão lá. Façam um mapa dos subúrbios. Lá está o choro, plantado, se alastrando nas rodas pobres dos domingos, feriados e dias santos de guarda, quilombando, longe dos patrões. E dos patrões e dos patrões. Levado pela mão dos amadores, machuchos, teimosos e dissimulados. Tocado e ouvido. $O$ esquecimento que impuseram aos mestres, intérpretes e compositores, carrega em vez de esfriar e dá força aos amadores, sem nome nos jornais, na tevê, nas revistas, nas capas de discos, nessa merdalhada toda.

Eles têm rixa e gana, birrentos, orgulhosos na humildade e persistem, como se carregassem sozinhos os trens nas costas. E, como se isso fosse sem quê, sem pra quê.

É. Mas eles sabem."

Paulo Melado do Chapéu Mangueira Serralha Conto de João Antônio

“São Caetano do Sul e Osasco, subúrbios industriais”, assinado por Antônio Rocha Penteado e Pasquale Petrone foi publicado em 1958, quatro anos antes de Osasco se emancipar politicamente da Capital paulista. Sua estrutura argumentativa é bastante consagrada pelas tradições francesas da Geografia, em ordem: a descrição do meio utilizando termos da chamada geografia física, acompanhada da descrição da ocupação do solo, análise das assim chamadas "funções urbanas" seguidas de comparações intra-metropolitantas para, finalmente, apontar para a necessidade do planejamento urbano. O texto em exame trata "os subúrbios paulistanos” e integra o quarto volume de um compêndio denominado “A Cidade de São Paulo - Estudos de geografia urbana” que foi dirigido por Aroldo de Azevedo.

Para os autores, Osasco constituía naquele tempo o principal “aglomerado” da "região”, mantendo ligação com outros três "núcleos": Presidente Altino, o Jardim Piratininga e Duque de Caxias, além de outros de menor relevância. Esses três núcleos são também denominados por “satélites” da cidade de Osasco e, contém na “função industrial” seu maior destaque, mesmo que se comparados a São Caetano, Santo André e Santo Amaro estivessem em estágio inicial do desenvolvimento industrial. Há algumas passagens que sugerem uma confluência entre métodos, mesclando termos de ambas as Geografias: tanto a física ao descrever a morfologia da paisagem das colinas que se elevam ao norte, das várzeas próximas ao rio Tietê e também dos terraços fluviais abaulados ou aplainados com altitudes que variam entre 725 e 735 metros acima do nível do mar; 
quanto à geografia humana, ou até urbana, que versa sobre o sítio urbano e seus "satélites”. Tal confluência se demonstra pela explicação do "habitat" ${ }^{8}$ ", clássico termo da Geografia na busca da união entre sociedade e natureza em sua análise, pois a preferência da ocupação em Osasco se deu em: "áreas enxutas - colinas e terraços fluviais, ao passo que as várzeas aparecem, em largos trechos, inteiramente desabitadas, e os trechos ocupados correspondem à atração exercida pela ' $E$. F. Sorocabana”", que corria desde os primeiros povoamentos dessa “região”. A proximidade com a estação ferroviária aliada aos baixos preços dos terrenos de várzea foi um atrativo para implementação das primeiras indústrias, outro momento de confluência de estilos na análise geográfica sobre determinações da corografia, mas logo se percebeu que a área estava exposta às inundações do rio, antes dele ser retificado e das obras de drenagem, diga-se de passagem. A igreja, construída em uma colina, e a presença da estrada de rodagem de Itu formando o núcleo da Bela Vista são apresentados como os outros dois núcleos que aos poucos foram se juntando à área varzeana próxima à estação.

Interessa apontar para a utilização de termos advindos das ciências biológicas na passagem anterior, pois isso desvela que a linguagem geográfica daquela conjuntura que colocava força nos termos “científicos”, por que não dizer positivistas, em busca de maior precisão descritivo-analítica, parte da mesma base das teorias do chamado darwinismo social, em que noções mal interpretadas sobre “adaptação” justificam políticas de Estado para planejar, higienizar, exterminar aos não adaptados, e, assim como ocorre no mundo da biologia, “naturalmente”. É possível dizer que o texto em questão é tributário da tradição descritiva da Geografia regional francesa e, por outro lado, traz alguns aspectos de uma renovação para além do paradigma geográfico da relação homemnatureza na busca de uma análise da apropriação social da natureza, muito embora essa tentativa seja carregada de uma noção positiva de progresso através do desenvolvimento industrial. Ainda assim, parte-se de uma noção estritamente material, uma concepção geométrica do espaço como base para as relações da sociedade moderna; nesse ponto, há um descompasso de ferramentas

8 Vale dizer que, embora seja um conceito transposto das ciências naturais e biológicas, o conceiro de "habitat” foi ressignificado teoricamente e continua sendo tematizado pela geografia urbana referenciada em Henri Lefebvre no sentido da moradia degrada, na qual o sujeito do morar vive um experiência reduzida especialmente em torno de sua reprodução enquanto trabalhador(a), ao mesmo tempo que os negócios imobiliários vão consolidar-se na produção capitalista do espaço. Observemos Max. Sorre em 1955, o autor considerado clássico da Geografia entende que “o habitat é a expressão última do gênero de vida”. Para ele “o estudo do habitat, isto é, das condições de estabelecimento dos grupos humanos na superfície terrestre e sua estabilidade, constitui um dos capítulos principais da geografia humana. Mesmo sem ir muito longe, deve-se admitir a permanência do habitat como a expressão mais concreta do arraigamento dos homens. A permanência corresponde a uma espécie de cristalização do espaço geográfico, e isto é verdadeiro tanto para o habitat rural como para o habitat urbano”. Para encerrar as considerações iniciais Sorre opõe como negação ao habitat a mobilidade ao certificar que "para o indivíduo e para o grupo, a permanência do habitat é a negação mesma de sua mobilidade. É, portanto, legítimo medir esta última em relação a características do habitat” (Sorre, 1984: 130). 
analíticas que, para a descrição da superfície ainda tinham ou têm serventia, mas que pouco dizem sobre a complexidade das relações sociais do capitalismo em suas abstrações reais.

“Povoamento e urbanização da região de Osasco” é o título do item seguinte, de caráter mais humano, histórico, por assim dizer. Pois bem, a história da ocupação de terras ali descrita admite uma primeira “abstração” das velhas propriedades de caráter exclusivamente rural, uma vez que a efetiva ocupação só teria se iniciado no final do século XIX quando Antônio Agu, um imigrante italiano, se instalou com uma fazenda nas proximidades do Tietê. Sem maiores explicações, diz-se desse italiano: "a ele se atribui uma série de iniciativas que vieram a culminar com a formação do Bairro da Estação, junto aos trilhos da ‘E. F. Sorocabana’ ’’(Petrone e Penteado, 1958: 97).

Em tom especulativo dizem os autores que "tudo parece indicar” que até a primeira década do século XX os habitantes ocupavam-se com atividades agrícolas, muito embora a qualidade dos solos varzeanos da futura cidade de Osasco não dessem nem para horticultura comercial; com isso, constataram, na observação feita em 1958, que até ali a “função” de Osasco nunca fora "agrícola”. Lembremos, então, da hipótese da “vocação rural” exposta por Roberto Grün (1992) em que a imigração armênia no Brasil é marcada por dois momentos. O primeiro, que conta com poucos registros, data do fim do século XIX, quando os imigrantes tinham como destino principal o trabalho nas obras dos portos do Rio de Janeiro e Santos. Entre estes recém-chegados, boa parte dedicou-se ao comércio ambulante, comprando e revendendo mercadorias. O autor cita o exemplo da família Gasparian ${ }^{9}$ cuja trajetória pelo comércio ambulante permitiu a entrada no ramo da indústria têxtil. Diante da dificuldade de acesso a terra a atividade comercial se apresentava como possibilidade a esses imigrantes:

A pouca necessidade de habilidades específicas para a realização da mascateação, inclusive o conhecimento básico do idioma, permitiu que esses imigrantes se aventurassem pelo interior até chegar às regiões que permitissem o desenvolvimento comercial. Assim, os primeiros armênios no Brasil chegaram a São Paulo nas décadas de 1900 e 1910, mas, sobretudo, na década de 1920, se estabelecendo no centro da cidade, juntamente com os sírios e libaneses, nas imediações das Ruas 25 de março, Pagé, Santo André etc. (LOUREIRO, 2012: 38-39).

No que se refere ao mascate nessa primeira fase da imigração armênia no Brasil, um de nossos entrevistados conta uma das muitas histórias que caracterizam a identidade e memória desse grupo de imigrantes, o mascate como possibilidade de reprodução ao imigrante recém-chegado:

Eles vieram, desceram em Montevidéu e a pé, fazendo mascate, comprando, vendendo mercadoria, compraram um cavalo, depois dois cavalos e depois seguiram a cavalo até chegar a Porto Alegre e depois a São Paulo. Os Keutenedjian, têm quatro, cinco famílias [que] conseguiram 
no ano 1895 mandar os filhos. (Hampartsum Moumdjian, em entrevista concedida no dia $13 / 05 / 2013)$

A mobilização desses imigrantes através do mascate permitia uma inserção com pouco dinheiro e nenhuma especialização. A mascatagem aparece como forma de mobilização do imigrante e em alguns casos, como os Keutenedjian que vieram ainda na chamada "primeira leva” ao final do século XIX, como personificação de capital acumulado. A chegada dos armênios mobilizados pelo genocídio e a formação de uma identidade como estratégia de reprodução na sociedade brasileira em uma conjuntura muito específica de formalização do mercado de trabalho no Brasil. O idioma a essa altura era mais um entrave para a inserção do recém-chegado no país, mas ao mesmo tempo pode ser pensado como fator que fortalecia os vínculos entre a comunidade armênia que vinha se formando.

Já a segunda fase da imigração armênia tem marco bem definido da metade dos anos 1920 em diante. Os imigrantes, em sua maioria, chegavam pelo porto de Santos e eram, em grande parte, sobreviventes do Genocídio Armênio. Os antecessores da chamada "primeira leva” formaram organizações de ajuda para estes recém-chegados, fundamentalmente em torno da Igreja Apostólica Armênia. Entre essas organizações destaca-se o Conselho dos Quarenta, espécie de conselho de armênios já estabelecidos em São Paulo que organizava a destinação dos recém-chegados.

Através da indicação deste Conselho os recém-chegados eram divididos entre aqueles que tinham vocação urbana e vocação rural $^{10}$. Como os critérios dessa divisão estabelecida pelo Conselho não são explicitados por Grün (1992), entendemos que, com base na apresentação desse mesmo autor e em outras fontes de nossa pesquisa, essa divisão suscita questões pertinentes para a nossa investigação. Entre os imigrantes, que no caso brasileiro eram oriundos principalmente da região da Cilícia, parte considerável possuía o conhecimento de algum ofício, sobretudo aqueles que ficaram nos orfanatos ${ }^{11}$ onde eram oferecidos cursos profissionalizantes. Nesse caso podemos indagar de que maneira o conhecimento desses ofícios contava para a classificação e destinação feita pelo Conselho.

Os imigrantes que eram identificados como sendo de vocação urbana eram encaminhados pelo Conselho para as proximidades do Mercado Central - Ruas Pajé (atualmente Rua Comendador

100 uso do termo "vocação” neste contexto faz referência ao discurso do referido Conselho em sua prática de encaminhamento dos imigrantes recém-chegados, no entanto, é preciso deixar claro que da perspectiva desta pesquisa a própria vocação é um desdobramento do processo de mobilização do trabalho.

11 No decorrer da guerra e nos anos subsequentes foram organizados, por franceses e americanos, orfanatos que recebiam crianças sobreviventes das marchas de deportação ao longo do deserto Del-El-Zor. Segundo Hampartsum Moumdjian (em entrevista concedida no dia 13/05/2013, arquivo pessoal do pesquisador) esses orfanatos localizavam especialmente no Líbano. 
Afonso Kherlakian) e Santo André - e para a Zona Norte da cidade de São Paulo - bairros de Santana e Imirim, ocupando-se com a fabricação artesanal e o comércio de calçados.

A um número menor de recém-chegados foi atribuída a chamada vocação rural, esses eram encaminhados ao bairro de Presidente Altino, como salientado anteriormente, que futuramente passaria a integrar a cidade de Osasco. De acordo com Grün (1992), estes se dedicavam primeiro à criação de gado leiteiro e depois à produção de iogurtes e coalhadas. De acordo com site da Comunidade Armênia de Osasco, entretanto, outras atividades teriam motivado o estabelecimento desse grupo identificado como de vocação rural: "uma parte dos armênios recém chegados a São Paulo decidiu se dirigir a Osasco e Presidente Altino, que na época eram bairros da Capital, pois lá encontravam trabalho na Cerâmica Hervy e no Frigorífico Wilson, além de terrenos a preço baixo $^{12 \%}$. Como exposto acima, tal hipótese é reforçada pelos autores Penteado e Petrone, que abstraem a presença armênia em Presidente Altino, ao dizer, na busca de algo como uma "vocação industrial”, que em Osasco já no início do século XX “desde logo se patentearam as vantagens que o lugar oferecia para as indústrias”, no caso, a vantagem salientada se baseava na proximidade da linha férrea e, em outras passagens os autores apontam, assim como o sítio eletrônico da Comunidade, para o baixo preço da terra. O subúrbio, como vir a ser do urbano é diferente de periferia em termos de renda da terra? Para José de Souza Martins o problema da renda urbana faz do subúrbio o lugar da espera, da especulação:

O subúrbio é, também, quantidade no lugar de qualidade, o banal no lugar do significativo. Por quê? Porque nele ainda prevalece a renda fundiária e a riqueza imobiliária - e a pobreza que deles decorre. A obra sucumbe diante do peso da renda territorial, hoje em dia sobretudo renda urbana, já capturada pelo capital, mediação que faz do subúrbio um lugar de especulação e não de criação. Um lugar que a terra (e seu preço) prevalece sobre o espírito (Martins,1992: 16).

Na primeira década do século XX instalaram-se a Companhia Cerâmica de Osasco e a Fábrica de Papel e Cartonagem, entendidos como embriões do parque industrial dos anos 1950. Evidentemente se reconhece que com duas empresas não se justifica uma “função industrial” e, com certo tom de lamento pelo progresso ausente, vão dizer os autores que ao início da segunda década do século XX o que havia na futura Osasco era um "incipiente aglomerado, com um reduzido número de habitações junto ao largo que se esboçava ao pé da estação e ao longo da via férrea.” Mas, em seguida e quase com alívio, anunciam o progresso junto da guerra de 1914:

O primeiro surto verificado em sua expansão teve lugar durante e imediatamente após a Primeira

Guerra Mundial. Foi a época em que novas e importantes fábricas ali foram instaladas: em 1915, o

12 Ainda de acordo com o site “(...) em 1928, os armênios de Presidente Altino decidiram congregar-se com a finalidade de auxiliarem uns aos outros nos planos material e afetivo. Realizaram uma reunião no dia $1^{\circ}$ de maio, na qual foram eleitos Keghan Karaghanian (presidente), Dikran Echrefian (vice-presidente), Hagop Guzelian (secretário), Sanazar Mardiros Lopoian (tesoureiro), Zefri Magdesian (bibliotecário), Tomas Kechichian e Arsen Bulbulian (conselheiros). Era constituída a "União Salmo Tzor de Presidente Altino". Disponível em: http://www.cao.org.br/origem.aspx, acesso em 04/07/2013. 
'Frigorífico Wilson do Brasil' estabeleceu-se junto à estação de Presidente Altino; pela mesma época, próximo à estação de Osasco, surgiu a 'Fábrica de Tecidos Beltramo \& Cia' e, junto aos trilhos da ferrovia, um mercado de suínos; já em 1920, ali se fixaram duas fábricas de fósforos, uma das quais - a 'Fábrica Granada' - aparece, até hoje, como um dos maiores estabelecimentos locais (PENTEADO E PETRONE, 1958: 98).

Nessa mesma época, apontam tais autores, é que se “cristalizam” os três núcleos de povoamento, caracterizando a “região” como um “tipo de 'habitat' que, embora com características urbanas, se aproximava do aglomerado-disperso (p. 100)”. Se, de um lado, o estudo aqui analisado abstrai a armênia imigração e enfatiza a presença de imigrantes italianos e seus descendentes, por outro lado, ressalta a importância do Frigorífico Wilson ao afirmar que Presidente Altino "se desenvolveu praticamente à sombra” de tal empresa, mobilizando operários que passaram a residir nas proximidades do frigorífico. Damiani (2004) analisa essa realidade suburbana em contraponto à vida da capital paulista que naquele tempo se espelhava no estilo francês: "no subúrbio empobrecido de vínculos com a História, havia a alienação do morador-trabalhador, que aparecia como cidadão menor, mantendo a cidade como real somente de modo irrisório e insignificante” (Damiani, 2004: 22). Sobre esse momento histórico nosso entrevistado Setrak Kachikian ${ }^{13}$, por outro lado, traz mais informações acerca da importância do Frigorífico Wilson no emprego de mão de obra armênia:

O fundamental mesmo, o grande elo era a Cerâmica Hervy, perdão, era o Frigorífico Wilson [interrompe a fala porque estava passando um carro de som de candidatos políticos desejando “feliz natal”]. O grande elo era o Frigorífico Wilson, por quê? Aquele tempo lá o Frigorífico Wilson, a gente chamava o frigorífico... em turco era "matador", matador. Em turco quer dizer um centro que mata boi e coisa parecida, um frigorífico. Em turco chamava "matador". Então, naquele período o pessoal emigrou pra cá, emigrou pra cá e veio morar pra cá, então, vieram umas famílias boas, inclusive uma boa parte dessa família é de Sis, que hoje chama Kosan. Aliás, quase todos eles compraram casa uma ao lado do outro, a colônia de Sis era uma colônia bem fundamentada, era uma colônia que tinha bastante conhecimento. Haja visto que eles compraram um terreno também em nome de Sis: "União Compatriota de Sis", o nome correto. "União Compatriota de Sis” era um terreno na Rua Armênia (localizada em Presidente Altino) que hoje eles venderam, com o dinheiro daquele terreno nós compramos a propriedade pra Igreja, aqui. Então, tinha esse elo dos armênios que eram coligados à União Compatriota de Sis. Fora isso, os armênios vieram pra cá em função do frigorífico oferecer emprego pra mão de obra não 13 Setrak Kachikian, entrevista cedida em 22 de dezembro de 2015 na Comunidade Armênia de Osasco, localizada na Rua Carlos da Costa Ramalho Júnior, 497, bairro de Presidente Altino. 
qualificada. Que quer dizer “mão de obra não qualificada”? Era mão de obra brutal, você pegava carne, carregava, colocava na geladeira, tirava carne, contava e mal e mal sabiam fazer a palavra, ou se não, conhecimento... Isso que eu tô falando é na década de 1929, 1930, 1932 que eles chegavam aqui em Presidente Altino na década de 1927, 1928, por aí construíram a Igreja e alguns deles trabalharam na Cerâmica Hervy, mas a Cerâmica Hervy não foi o alicerce como foi o Frigorífico Wilson. Provavelmente por ser uma multinacional tinha mais regalia, tinha mais prestígio, tinha mais coisa para oferecer. Daí eles vieram pra cá sabendo que aqui tinha um loteamento grande e os armênios poderiam se erradicar pra cá, porque muitos deles estavam em São Paulo, Rua Santo André na área que o Riskallah Jorge ofereceu. Aí uma boa parte deles vieram pra cá, compraram o terreno e eu não sei explicar pra você como é que era a transação que eles mal e mal falavam em armênio, mas tinha um grande, um armênio no meio deles daí que tinha muita influência a respeito disso, que se chamava Hagop Kuzelian, Hagop Kuzelian [que fora o primeiro secretário da Comunidade Armênia de Osasco, em 1928 como mostra a nota a primeira reunião entre os armênios de Presidente Altino em $1^{\circ}$ de maio de 1928 . Atualmente há uma Rua em Presidente Altino com esse nome]. Ele ajudou muito os armênios a adquirir as propriedades, ele era meio intermediário pra fazer esse trabalho e aqui, eles vieram pra cá, uma mão na frente, uma mão atrás. Então, o curioso disso, nenhum tinha profissão qualificada, uma boa parte trabalhava como sapateiro, uma boa parte como costureiro, uma boa parte...uma boa parte desses daqui, o que eles faziam, eles criavam gado, gado, vaca leiteira que na época que eu tô falando é coisa de 1943, 44, 1945 eles criavam vaca e dentro desse terreno de 500 metros (futuro terreno da CAO) eles tinham uma pequena cocheira e tirava leite da vaca. Com esse leite eles faziam coalhada, em armênio a gente chama: “matsun”, “matsun”.(...) Essa coalhada de um dia pra outro cê fazia ela em lata de óleo; aquele tempo a lata, o óleo vendia-se me lata de um litro, não sei se você chegou a ver... 


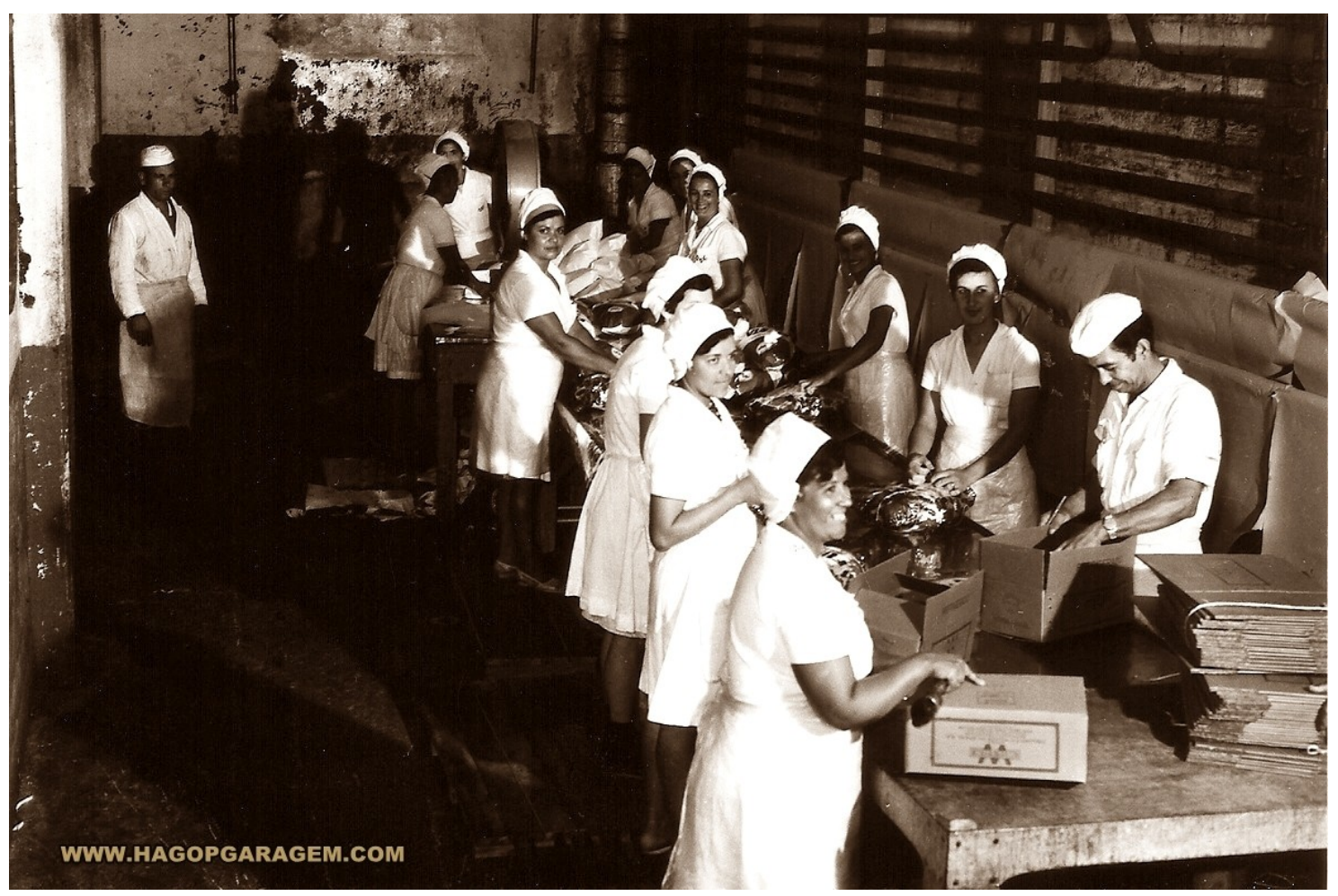

Foto 1 - Setor de embalagens no interior do Frigorífico. Interessante notar a forte presença da mão de obra feminina, algo que não foi ressaltado nem pela bibliografia, nem pelo entrevistado. Fonte:

http://www.hagopgaragem.com/osasco/galeria1/industria_wilson/wilson_22_gr.jpg

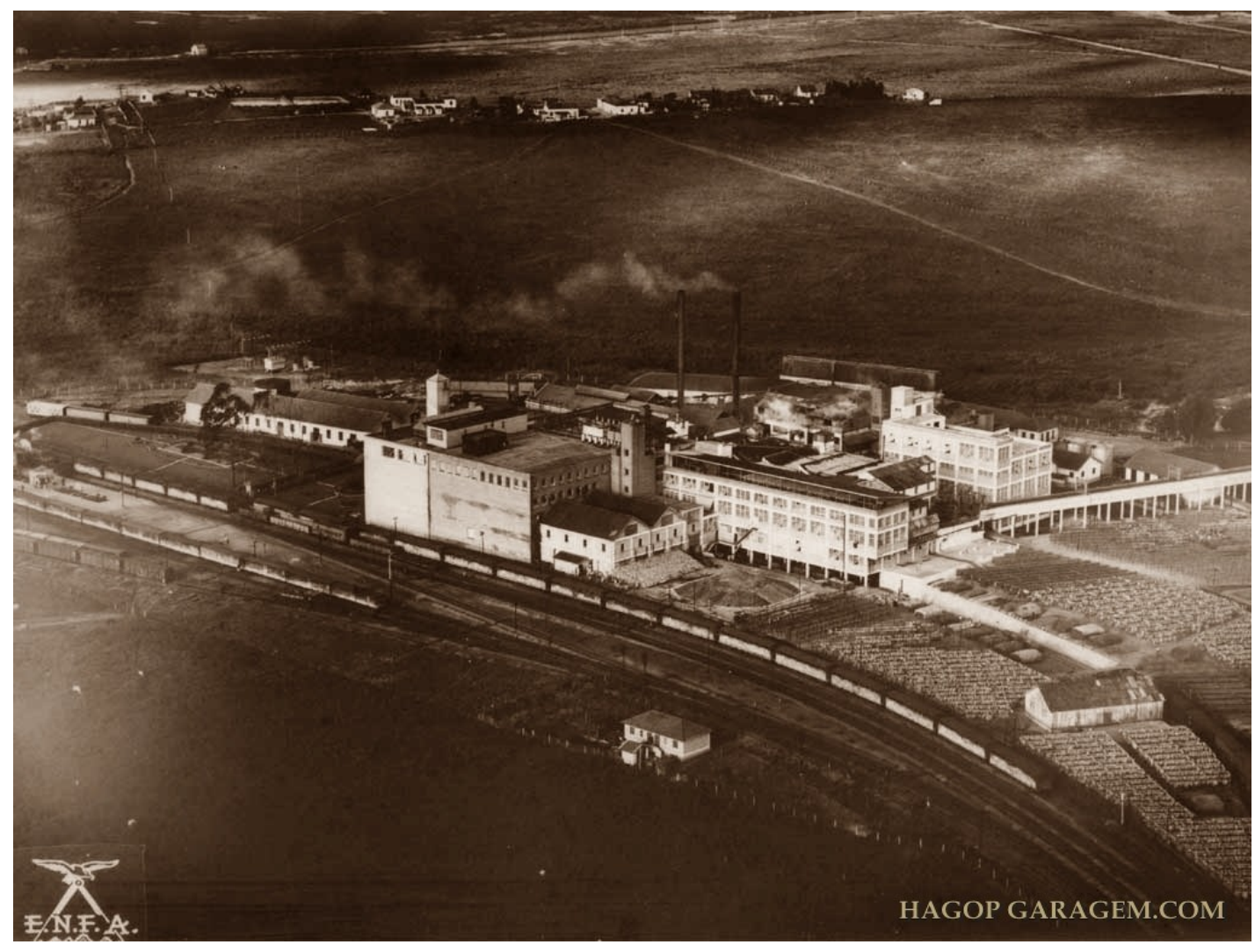

Foto 2 - Imagem aérea do Frigorífico Wilson no ano de 1939, Presidente Altino. Além da proximidade da linha férrea, é notável como a área era pouco ocupada. Fonte:

http://www.hagopgaragem.com/osasco/galeria1/industria wilson/wilson 5 gr.jpg 
Esse trecho da entrevista é revelador em muitos aspectos. O primeiro deles é estabelecer relação com a cidade de origem da maior parte dos armênios de Osasco, Kosan que atualmente faz parte da histórica cidade de Adana, o que pode apontar para uma organização interna anterior ao estabelecimento desses imigrantes já em Presidente Altino através da "União Salmo Tzor de Presidente Altino". Com isso, o argumento de Grün (1992) a respeito da “vocação agrícola” orientada pelo Conselho dos Quarenta se torna mais complexo; mais ainda, o fato desses imigrantes não trabalharem com atividades agrícolas para além da extração de leite e confecção de coalhadas (nesse fato o entrevistado e o levantamento de Grün estão de acordo), mas sim trabalharem ocupando postos de “mão de obra não qualificada” em um frigorífico ou uma cerâmica os aproxima, do ponto de vista das relações de trabalho, a um cotidiano “urbano”. Podemos relativizar também o lugar social de “mão de obra não qualificada”, pois como o entrevistado deixa entender que “uma boa parte trabalhava como sapateiro, uma boa parte como costureiro", o que não deixa de ser uma qualificação profissional e que na época certamente tinha um poder de distinção social maior do que nos dias atuais. Cabe ainda a ressalva de que na própria entrevista - como poderemos ver mais adiante no clientelismo institucional na figura de Jânio Quadros em relação ao fornecimento de água em Presidente Altino - e a partir do texto de Penteado e Petrone existem indicações de Presidente Altino como um “núcleo” aquém da modernidade urbana da capital durante a primeira metade do século XX.

Se de um lado o Frigorífico Wilson era a empresa que mais mobilizava armênios ao trabalho em Presidente Altino, a Cerâmica Hervy cumpre um papel ímpar na formação do bairro, uma vez que era responsável pelo loteamento e suas condições de financiamento. Novamente nos informa o entrevistado:

Setrak: (...) quem loteou toda essa gleba de Presidente Altino, tem uma área industrial e a área comercial. Quem construiu, quem vendeu foi a Cerâmica Hervy. Companhia Cerâmica Industrial de Osasco, Hervy. Ela fabricava bacia pra banheiro, fabricava lavatório, fabricava tubo e ela introduziu um loteamento chamado Presidente Altino, deixa eu fazer um parêntesis e dizer porquê que chama "Presidente Altino". Tinha a estação da [Estrada de Ferro] Sorocaba, tinha a Estação Domingo de Moraes, tem Estação Lapa, Vila Leopoldina, Osasco e assim sucessivamente... a estação de Presidente Altino foi dada esse nome porque o presidente da época, o governador chamava “presidente do Estado". Era Altino Arantes e foi dado em nome de Presidente Altino em graças ao Altino Arantes que era governador do Estado [de São Paulo] naquele período (1916 a 1920). Então foi dado esse nome Altino, Presidente Altino que ele era presidente do Estado, não governador como é hoje. Aí eles começaram a vender, vender a preços cômodos e com prestações bem longas, não sei quantos anos era dada a atividade, mas o pessoal começou a adquirir, 
começou a comprar e então o pessoal já começou... aí na década, na década, quando Jânio Quadros era governador e eu não lembro o período correto [entre os ano de 1955 a 1959], ele conseguiu trazer água pra Osasco, água pra Altino. Então você não precisava ter poço pra funcionar, aí o pessoal já utilizava a água, já fazia o banheiro, já fazia a caixa d'água pra poder desenvolver ou criar melhor os filhos e assim foi. Se não me falha a memória, não lembro direito 1960, 1962 que veio a água pra cá.

Recorremos, outra vez, ao trabalho de Damiani (2004), pois este demonstra como era comum a articulação entre capital privado, visando a valorização fundiária do urbano como porvir ou já realizado, e as instâncias do poder público na melhoria de infraestrutura. Esse tipo de articulação, historicamente na cidade de São Paulo, conferiu a um pequeno grupo de empresas ${ }^{14}$ uma gama de privilégios, autorizações especiais, exclusividade de direitos que parece ser decisiva para a concentração de capitais da época:

(...) a propriedade da terra urbana ou potencialmente urbana, disposta na periferia do núcleo arruado, esteve concentrada nas mãos desses mesmos empresários. E esses investidores mantêm um corpo de investimentos, que envolve também: ferrovias, instituições bancárias, indústria, produção agrícola para exportação - da cana de açúcar ao café - empréstimos a juros, introdução de imigrantes e outros (DAMIANI, 2004:22).

A concentração de capitais, como demonstra Marx ao final do Livro Primeiro de O capital, é a lei geral da acumulação capitalista (MarX, 1984: cap. XXIII) e anda a par e passo com a centralização de capitais dada pela concorrência entre capitais individuais e/ou associados que a cada realização da produção no mercado tornam a disputa pela mais-valia global uma disputa mais arriscada em constante mudança na composição entre maquinaria e força de trabalho. Porém, o alto nível técnico só possibilita a entrada nessa corrida a aqueles capitais em grande volume ou a aqueles que pareçam suficientes para pagar juros com seus lucros e, com isso, o entrelaçamento entre sistema de crédito e produção "se transforma em um enorme mecanismo social para a centralização dos capitais” (Marx, 1984: 197). O processo global da produção desvela, assim, que dinheiro pode se transformar em mais dinheiro através do juros que o capital financeiro aplica sobre o capital que explora a força de trabalho produtora de mercadorias para obter dessa produção lucro suficiente para pagar os juros que o capital financeiro emprestou. A produção de mais-valia no âmbito privado vai testar seus valores no preço de mercado. Como prêmio de um salto mortal bem sucedido da mercadoria diante do público (mercado), o capital que produziu tal mercadoria retira sua fatia do

14 Para este tema, vale a consulta da excelente Tese de Doutorado de Odette Seabra, que explicita como a empresa canadense "The São Paulo Tramway Light and Power Co. Ltd.” operou em regime de concessão no Brasil, usufruindo de certos privilégios para ampliar seu capital também por meio do negócio dos loteamentos das várzeas do rio Pinheiros e Tietê. SEABRA, Odette C. de Lima. Os meandros dos rios nos meandros do Poder. Tietê e Pinheiros: valorização dos rios e das várzeas na cidade de Paulo. Tese de doutoramento. São Paulo: FFLCH/USP, 1986. 
bolo, sua quota da mais-valia global. Além disso, neste processo fica evidente que o valor de uso da mercadoria fica abstraído, muito mais como meio do que como finalidade do processo de valorização - bandeira souvenir, drones que soltam bombas ou bombas de chocolate - e referente à exploração do capital sobre a força de trabalho na produção que surge como incógnita e não como garantia de rendimento capaz de remunerar o capital emprestado e reproduzir ampliadamente o capital diretamente produtivo. Junto a isso, somente na mirada para o entrelaçamento de capitais em suas várias escalas, da relação-capital enquanto totalidade, ou como gostava Kurz (2004) como “totalitarismo econômico” que se faz possível alguma compreensão do fetichismo da relação entre valor e preço.

A centralização como meio da acumulação de “expandir a escala de suas operações” (Marx, 1984: 197) segue dois caminhos, o caminho mais “tranquilo” da formação de sociedades por ações, que além de juros entrelaça mercado de futuros a partir de projeções fetichistas da produção presente e seus descolamentos que de tempos em tempos acarretam em quebradeiras e crise. O caminho violento, por sua vez, é o caminho da anexação quando certos capitais tão superiores “atraem fragmentos isolados” (idem) para seu campo gravitacional, além da possibilidade de fusão de capitais. O caso dos trustes é desdobramento da reunião de uma sociedade de ações de um mesmo ramo de negócios que visa monopólio.

Nesse ponto que é de interesse trazer à baila o centenário ensaio popular de Lenin sobre o imperialismo, pois nesse debate da expropriação metropolitana (Seabra, 1986 e Damiani, 2004) é o domínio da exportação de capitais monopolistas como os da Light ou Cerâmica Hervy que adquire capacidade de gerenciamento político - arruamentos, legislação da terra; e seus rendimentos se concentram nas mãos de empresas como mais de uma fonte de rendimento. Escalas entrelaçam capitais monopolistas de diversas partes do mundo e a produção se materializa no subúrbio e assim as noções funcionalistas dos geógrafos em 1958 perdem força de explicação ao se restringirem à materialidade cartesiana da evolução morfológica em seus mapas.

Mas voltemos à escala suburbana, que hoje muitas vezes transformou-se em periferia incrustada ao tecido urbano da metrópole, a partir da discussão proposta de Giovarotti (2012) para pensarmos naquele período da Primeira República (1889-1930), tempo de subúrbio ainda em meio à autonomização da fontes de rendimento do processo de produção social: terra, propriedade privada do globo terrestre - renda fundiária; capital - juros; e trabalho assalariado - salário (Marx, 1985: cap. XLVIII). Eram relações de produção saídas a pouco do escravismo para o mercado regional que sofre mudanças profundas com a mobilização geral da Grande Guerra, reordenando uma população para o capital fora da Europa. Tal qual sugere o supracitado argumento de Damiani, a empresa chave para a urbanização de Presidente Altino, a Cerâmica Hervy concentrava capital a 
juros para o pagamento dos lotes comprados pelos imigrantes, capital explorando o trabalho ${ }^{15}$ na cerâmica e a propriedade do loteamento. Através de Giavarotti aparece como pergunta/hipótese se a não autonomização das fontes de rendimento constitui a grande diferença entre subúrbio e periferia, diferença que se transforma ao longo do processo histórico do século XX em internalização das regiões e das populações deslocadas por alguma guerra na(s) metrópole(s). São Paulo, desde a inflexão do momento regional em 1930 a partir da autonomização das categorias da relação-capital (Giavarotti, 2012: 100) e o gradual processo de internalização da metrópole (Giavarotti, 2012: 120), está articulada à escala do Estado que na gestão da riqueza nacional abstrata, tal qual os países ocidentais, seguirá os ditames da gestão estatista além do pós-guerra para depois alternar entre o pêndulo estatismo e liberalismo (Kurz, 1992).

A separação entre as fontes de rendimento, em particular da terra e do trabalho, sempre atrelada ao capital enquanto fonte de rendimento capaz de mobilizar trabalho e terra, mostra que deriva da renda da terra a mobilização da força de trabalho que têm necessidade de se reproduzir em alguma moradia e para isso paga um tributo ${ }^{16}$ para usufruir de uma porção do globo terrestre. E o lugar da especulação da renda da terra caracterizado por Martins (1992), como vimos, é o lugar da espera da valorização e também à espera do Estado no que diz respeito às condições de habitabilidade e urbanização.

Nesse sentido, a descrição do entrevistado sobre a falta de infraestrutura em Presidente Altino até a década de 1960 traz alguns elementos de quem viveu no bairro de modo a ampliar a interpretação de Penteado e Petrone sobre a urbanização da área. Depois de exaltarem os primeiros surtos industriais na primeira década do século XX, os autores afirmam que de 1920 a 1930 a expansão urbana de Osasco declina e que somente após a Segunda Guerra Mundial ocorre um crescimento e a efetiva "ocupação da área”, uma vez que numerosas fábricas vão ali se instalar. Decorrem dessa expansão industrial o fenômeno da conurbação e a integração metropolitana, ainda que com outros termos e em tom progressista:

O povoamento intensificou-se por tal forma que deixou de existir solução de continuidade entre os três núcleos primitivos, unidos num só conjunto, desde Presidente Altino até Duque de Caxias. O casario deixou de prender-se à ferrovia, esparramando-se em direção ao Sul, notadamente junto à estrada de Itu. Através da Lapa, de um lado, e do Butantã, de outro, a região de Osasco "soldou-se” definitivamente à metrópole paulista. Dessa maneira, passou

15Vale relembrar a opinião do entrevistado alguns parágrafos atrás dizendo que : “eles (imigrantes armênios) chegavam aqui em Presidente Altino na década de 1927, 1928, por aí construíram a Igreja e alguns deles trabalharam na Cerâmica Hervy, mas a Cerâmica Hervy não foi o alicerce como foi o Frigorífico Wilson”.

16 Como pode ser interpretado a partir do capítulo sobre a Gênese da renda fundiária no terceiro livro de O capital de Marx, tributo precisa ser entendido em processo, sendo diferente no momento em que a renda da terra é a principal forma de extração de mais-trabalho, mais-produto e mais-dinheiro; e no momento em que a mais-valia em sentido especificamente capitalista através das formas de extração acima citadas. 
aquela a sentir diretamente a influência desta, cujo ritmo de crescimento procura seguir, na medida de suas possibilidades, e de cuja vida passou a ser parte integrante (PENTEADO E PETRONE, 1958: 101).

O mercado, a indústria e o aumento populacional ${ }^{17}$ sugeriram outro tratamento da questão urbana que, a partir da década de 1950, passou a utilizar o termo “metrópole” especialmente por causa do desenvolvimento industrial. Mais ainda, a metrópole passava a representar a forma geral, pautada na mediação do dinheiro, da sociabilidade moderna, como uma "mudança quantitativa e espacial da experiência urbana” (Damiani, 2004: 23). Em Giavarotti a metropolização é consequência de um processo histórico a partir da realização e acumulação de determinada relação social e "para que São Paulo se torne o centro modernizador do território nacional, será necessário que concentre, mais do que capital na forma de dinheiro, meios de produção e infraestrutura...enfim, mercadorias (Giavarotti, 2012: 95)”. Parece interessante observar, ainda, que o estudo de 1958 apresenta um movimento interno contraditório em suas explicações, pois há uma espécie de "ir-evir" atrás de algo como uma "história do progresso industrial”, o que acaba por vezes projetando a assim chamada "função industrial” em momentos anteriores à sua concretização. Mas, a chamada “função industrial” não poderia dar um passo além da história e constituir-se em "subúrbio industrial” antes que houvesse condições materiais e suficiente aporte de capitais investidos nessa metrópole que se formava. Pode-se dizer, com isso, que os autores realizam uma interpretação embebida no olhar de seu próprio tempo, além do que, uma interpretação que atribui à linguagem da cartografia um conteúdo explicativo em si, bastando observar a "evolução" da morfologia urbana para entender seus processos e conteúdos.

Seria a internalização da metrópole o processo de passagem também do rural ao urbano, em outros termos e ao longo só do século XX, do subúrbio à periferia? Como isso se coloca em relação à precificação da terra em áreas que estavam passando do rural ao urbano?

Para além da acumulação de capitais realizada pelos cafeicultores paulistas ao longo do XIX e XX como hipótese para a industrialização do sudeste brasileiro durante a Era Vargas, segue como questão a polêmica acerca da industrialização (?) brasileira no período da Primeira República (1889-1930). De onde vinham os recursos financeiros para o início das fábricas? Eram mesmo fábricas ou pequenas oficinas familiares? Como se entrelaçam sistema de crédito e concorrência nessas pequenas oficinas familiares? Perguntas e mais perguntas.

17 Penteado e Petrone recorrem às estatísticas para demonstrar o significativo aumento populacional do subdistrito de Osasco da década de 1940, quando possuía 15.258 habitantes, para a década de 1950 quando a cifra atingiu 43.473 em “população absoluta” (1958:101). 
Em um dos casos de constituição de fábrica familiar em Altino que tivemos contato por meio de entrevista, a unidade era do ramo têxtil e vendia ternos para lojas de judeus na Rua José Paulino já no período do Estado Novo.

(Setrak) : Eu sou de trinta e nove. E aí meu pai começou a morar, morou. Fundou, começou a trabalhar de alfaiate, aí começou a criar os três filhos. Eu quando era pequeno quando tinha uns seis sete anos estudei no Externato José Bonifácio em São Paulo (escola armênia), não onde ele está hoje (Av. Santos Dumont, 55), e sim o antigo que ficava perto da [rua] Paula Souza, não sei dizer o nome pra você, um prédio antigo. Eu me lembro alguma coisa que eu aprendi lá, aí de lá nós mudamos para Osasco. Meu pai conseguiu uma reserva de um dinheiro que ele tinha, comprou um terreno e edificou uma pequena casa para ele, uma casa até confortável, não era mau.

(Artur) - Em que ano mais ou menos?

(Setrak) - 1949, 50... e essa casa nós já éramos crescidos, 12 anos, 13 anos. Meu pai tinha uma oficina de costura e essa costura que ele fazia era pra uns judeus que tinham loja na Rua José Paulino. Então ele costurava paletó, o jaquetão, pra poder levar na José Paulino e eles darem o acabamento, passar tudo direitinho e por na loja pra vender. E assim, vendia horrores, e de lá ele foi fazendo esse tipo de trabalho até a gente crescer, quando nós crescemos, nós já começamos a dar um pouquinho mais de liberdade, ou se não, mais de liberdade financeira, inclusive. Aí, com muito custo, ele comprou um terreno no fundo da casa onde ele havia construído que fazia um “éle” [a letra L]. Também com um recurso que ele economizou, aí nessa altura ele abandonou esse trabalho de costura e montou uma pequena fabriquinha de chinelo havaiano: chinelo havaiano. Como tem esse chinelo que você conhece, de um dedo. Montou uma fábrica, mas não do naipe, tipo do havaiano que é hoje, um pouquinho mais barato, mais artesanal, mais simples, né?

A mudança de um ramo industrial (se é que assim pode-se classificar) para outro, no caso, do ramo têxtil para o calçadista, pode indicar que o sentido da reprodução da força de trabalho não está na aptidão nata, nas tradições ancestrais de uma cultura, mas sim na necessidade imposta pela valorização do valor. Assim, troca-se de máscara frente à sociedade do trabalho e, o curioso de tudo isso é que, a máscara calçadista foi a personificação que mais se encaixou nos armênios e ainda hoje possui sobrerrepresentação no imaginário paulista (Loureiro, 2012).

As condições materiais dos recém-chegados da guerra de 1914 e dos orfanatos americanos e franceses na Síria e no Líbano eram, na maioria dos casos, típicas de trabalhadores livres que, por serem desprovidos de qualquer meio de produção, têm na venda de sua força de trabalho a única forma de se reproduzir. Não raro nossos entrevistados dizerem que os imigrantes chegavam ao Brasil com "uma mão na frente e outra atrás”, o que pode inclusive compor a imagem personificada desses imigrantes como "vencedores" nesse novo mundo concorrencial, seja na capital seja nos 
subúrbios. Aparece como característica inapta da assim chamada armenidade uma espécie de “capacidade adaptativa” em qualquer lugar, qualquer situação:

Meu pai em Montevidéu, quando chegou no ano 1928, eles lá no Líbano, depois que saíram de Zeitun, faziam tapetes, tear. Por quê? Porque as pessoas sentavam no chão e a cá, não, a cá sentam em cadeira. Então ele comprou uma tábua, começou a cortar e fez cadeiras para usar. O armênio sempre se ubiquou, se ambientou no âmbito em que eles estava, sempre conseguiu. (Hampartsum Moumdjian, filho de refugiados nascido em Montevidéu, Uruguai)

Tal forma de reprodução em muitas circunstâncias esteve diretamente relacionada a um círculo de sociabilidade armênia. A esse fenômeno Grün atribuiu o conceito de "especialização funcional”18 que é relativo à produção de calçados pelas empresas familiares de imigrantes e seus descendentes, bem como, atribuiu um conceito à associação entre famílias armênias criando “facilidades” para a criação de novas unidades produtivas familiares, a assim chamada "ajudamútua”. A reprodução dos armênios nesse contexto, tendo em vista em quais condições eles exercem a sua dupla liberdade (Gaudemar, 1977) nos permite criticar a perspectiva que entende o elo dessa produção como cultural estritamente, inclusive pelo fato desse tipo de mobilização não constituir uma regra intracomunitária. Houve, e é nesse aspecto que as entrevistas são contraponto das generalizações, outras tantas formas de personificação dos imigrantes a partir da inserção destes em variadas posições no mercado de trabalho, capitais e terra. No caso dos imigrantes que foram morar em Presidente Altino, o fascículo publicado em 1992 pela Comunidade Armênia de Osasco (CAO) intitulado "Armênia: um país soberano que renasce das cinzas" faz um apanhado desse momento histórico em que os armênios iniciaram suas trajetórias profissionais no bairro. A publicação foi feita em comemoração à visita à CAO em junho 1992 do primeiro presidente armênio depois do colapso da U.R.S.S., Levon Ter Petrossian ${ }^{19}$. Além de citar aqueles que

18 Segundo consta no texto, a especialização teria origem na antiga Província de Marash (atualmente uma capital provincial turca, na origem uma das principais províncias da Armênia Ocidental), local de origem de grande parte dos armênios que vieram ao Brasil. Essa versão é contestada pelo autor pelo fato dos sapatos serem de baixa qualidade e preço baixo, ou inferior ao dos concorrentes de origem italiana. Além disso, no texto destaca-se que já na terceira geração a ocupação majoritária entre os armênios é o comércio, em detrimento da indústria. Com isso, Grün ressalta que essa imagem do armênio-brasileiro ligado à produção de calçados foi uma construção que "colou” no imaginário brasileiro, sendo utilizada inclusive para justificar uma possível acusação de inserção social oportunista. Para o autor, a reiteração dessa cultura seria uma forma de fomentar uma espécie de “capital simbólico”: “o registro social de que a sua inspiração nos modelos de calçados vem de séculos de tradição, positivamente enobrece seus produtos” (GRUN, 1992: 41).

19 O texto foi publicado no Diário de Osasco na época e a pesquisa e redação foram feitas pelo primeiro prefeito da cidade de Osasco, Hirant Sanazar, que era descendente de armênios e presença constante na CAO. Em 2014 a Ponte do Jaguaré na Marginal Pinheiros recebeu o nome do ex-prefeito. Além do ex-prefeito, seu irmão, Achoute Sanazar, foi presidente da Câmara de Osasco nos anos 1960, o que mostra a forte presença da CAO na vida política da cidade de Osasco desde os anos 1960. 
trabalharam no Frigorífico Wilson, algumas das profissões (sempre masculinas) são enumeradas para retratar aqueles que "foram, iniludivelmente, os açougueiros, os sapateiros, fotógrafos, barbeiros, vendeiros e operários de frente ou de retaguarda que mantiveram a estrutura familiar, social, espiritual, e comunitária das correntes imigratórias, que fizeram de Osasco a consagração de suas sobrevivências condignas”. Dessa forma, a personicação dos imigrantes armênios de Osasco relativa às suas ocupações apresenta uma gama de variações bastante mais ampla do que a simples “vocação rural”.

Riskallah Jorge Tahinian, nascido em Alepo, casado com a armênia Zackie Nacachian e neto de armênios, proprietário da Casa Bóia, empresa relevante no ramo de insumos fabris já nos anos 1920, aparece como um importante benemérito na medida em que transformou o andar superior de sua loja na Rua Florêncio de Abreu, 13, centro de São Paulo, em uma “mini-hospedaria”. No entanto, sua participação na comunidade e entre os recém-chegados ia muito além de relações com mediadas pela Igreja e abrangia também dinheiro a juros, crédito em insumos e maquinaria

A partir da Casa da Boia de Rizkallah Jorge, muitos armênios se inseriram na economia paulistana. O proprietário desse estabelecimento fornecia insumos para os compatriotas e esses partiam negociando os produtos feitos com aquele material. Quando a situação permitia, os armênios abriram pequenas oficinas de confecção e reparo de calçados, lançando mão da borracha, cola, linha, etc., financiadas por Jorge. Segundo Grün, o empresário dava crédito ao conterrâneo recém-chegado mediante a apresentação deste por alguém ligado à comunidade - sobretudo à Igreja - formando assim uma hierarquia dentro da coletividade, bem como uma cadeia de prestígio e respeito dos seus pares (Loureiro, 2012: 42)

Foi neste endereço que aconteceram as primeiras reuniões religiosas entre os recémchegados (GRÜN, 1992). Em 2004 a Comunidade Armênia do Brasil publicou um “apanhado de dados históricos da Comunidade Armênia de São Paulo", o volume é comemorativo da "Visita Pastoral de S.S. Karekin II, Patriarca Supremo e Catholicós de Todos os os Armênios”. Nessa publicação há maiores informações sobre o benemérito Riscallah Jorge Tahinian que mostram forte vínculo com o Patriarcado da Igreja Apostólica Armênia do Brasil, Armênia e Síria. Ativo doador da primeira Igreja que ficava na Avenida Senador Queiroz, centro de São Paulo, demolida a partir de 10 maio de $1943^{20}$ como parte de reurbanização de ruas no centro da cidade do famigerado Plano de Avenidas de Prestes Maia. O Plano, que fora lançado em 1930, extendeu suas obras de 1934 a 1945, como conta Antonio Riscallah, neto do benemérito:

“(...) O Prestes Maia, na ocasião prefeito de São Paulo, desapropriou a Igreja para o alargamento da rua. O meu avô chamou os armênios e falou 'olha, vamos fazer outra Igreja,

20 Citação referente à página 38 In: "Visita Pastoral de S.S. Karekin II, Patriarca Supremo e Catholicós de Todos os os Armênios”. Publicação da Comunidade Armênia do Brasil, São Paulo, 2004. A publicação traz dois pequenos textos de interessa aos pesquisadores do tema, respectivamente: “A Diocése da Igreja Apostólica Armênia do Brasil” (p.37-44) e “Igreja Apóstólica Armênia de Osasco” (p. 45-46) e sobre Rizkallah Jorge nas páginas 68-69. 
vamos procurar outro terreno, mas que seja grande para fazer a Igreja e uma escola, mas quem vai fazer a escola é a coletividade armênia, porque assim vai ficar a essência do espírito armênio vinculado à escola, porque aprendeu, e à religião, que a Igreja fez entrar no sentimento do seu povo, para não esquecer as origens” (Com. Armênia do Brasil, 2004: 41)

Em 1945 “(...) o mesmo benemérito comprou outro terreno para a construção da nova igreja, dessa vez na então Av. Tiradentes 213, entre os bairros da Luz e do Bom Retiro, outro local de aglomeração de armênios em São Paulo” (LOUREIRO, 2012:56). A obra foi inaugurada em 03 de abril de 1949 e a consagração ocorre em 24 de abril do mesmo ano ${ }^{21}$.

As instituições da comunidade organizavam a socialização dos armênios em São Paulo sob a perspectiva da inserção econômica, por meio de casamentos entre membros da comunidade, através de auxílio por meio de empréstimos em matérias primas na confecção de calçados ou até em maquinário de tecnologia ultrapassada. O modo como as instituições da comunidade armênia exerciam influência sobre os recém-chegados representa uma tentativa de adiar a unificação dos mercados de trabalho, financeiro e comercial da comunidade armênia com a sociedade paulistana, de acordo com Grün (1992).

Nessa rede firmada entre os armênios recém-chegados pós-genocídio e os já estabelecidos se coloca a mediação da comunidade que aparentemente se define como cultural. Essa relação entre os recém-chegados e os já estabelecidos engendra uma dependência, sendo uma forma bastante vantajosa de mobilizar trabalho para os armênios portadores de capital e meios de produção, uma vez que muitas das relações de trabalho estabelecidas através da rede sequer tinham o assalariamento consolidado (GRÜN, 1992). O clientelismo pessoal, tão marcante nas formas de exploração do trabalho do Brasil durante as primeiras décadas do século XX, também deixou suas marcas nessa sociabilidade, de aparência fechada, entre armênios. Será a armenidade da metrópole produto de um laço cultural e/ou uma relação de dependência econômica intra comunitária?

Nesse contexto inicial de inserção dos imigrantes, além da importância de Riskallah Jorge para o estabelecimento de muitos armênios na metrópole através da produção de calçados, houve 
outra figura, Vahan Keutenedjian ${ }^{22}$ que residia na capital, de relevância para a comunidade em Presidente Altino:

(Setrak) - Quando eles vieram pra cá na década de 1927, 1928, por aí 1930. A primeira coisa que eles pensaram em fazer era construir uma igreja pra poder dignificar, pra poder dar continuidade à armenidade. O armênio é muito interessado em saber essas coisas. Aí montaram um grupo, tem até os nomes lá fora, eu posso dizer pra você, conseguiram comprar dois lotes de terreno, dois lotes. Exatamente onde está edificada a igreja, esses dois lotes. Esses outros aí foram posteriormente, depois de algum ano e lá eles começaram a construir a igreja, só a igreja. Começaram a construir sem projeto, sem planta, sem nada, tudo na base da economia comprava tijolo e mandava fim de semana alguém trabalhar e cada um ia dando um dinheirinho e ia construindo, construindo naquele período que não tinha, eles não tinham nem formação de como é que era que fazia, que não fazia. Num determinado tempo eles não conseguiram arrecadar o dinheiro pra dar continuidade porque tinha a parte mais difícil que era concluir, rebocar e fazer o telhado e fazer a parte religiosa que é o fundo da igreja onde tem a missa, onde se faz a missa. Haja visto que aí eles pensaram em fazer, pedir pra esse benemérito... o Vahan Keutenedjian, que na época tinha uma fábrica de, era um dos armênios ricos e já tinham vindo bem antes pra cá, antes de 1930, antes, bem antes, no começo da...bem antiga, no começo do século. E ele montou uma fábrica, se não me engano, uma fabrica de tecido.

(A) - Lanifício, né?

(S) - Lanifício Vahan, agora que eu lembrei, Lanifício Vahan. Aí foram falar com ele, num grupo desses mais conservadores, ou mais armênios, né? Foram falar com ele dizendo que eles tavam construindo a igreja, começaram construir, mas não conseguiam terminar porque tava precisando de dinheiro pra concluir. Ele imediatamente, ele falou: “eu aceito”. Não sei como foi a forma que ele falou, ele falou "aceito" e depois de uma semana mandou o pessoal dele aí, foi, foi, concluíram a igreja, terminaram a igreja. A única coisa que ele pediu, eles queriam homenageá-lo, ele falou

22 Op. cit. p.46. Na versão do texto da Comunidade Armênia de Osasco:“A Igreja Apostólica Armênia São João Batista de Osasco tem sua origem em 1923, na imigração de cerca de 60 famílias procedentes de diversas regiões, principalmente na Anatólia que em 1928 organizaram a Sociedade Compatriótica 'Salno-Tsôr”, dedicando-se à estruturação da vida comunitária dos Armênios de Presidente Altino. Já em 1928 esta Sociedade adquire um terreno de aproximadamente $500 \mathrm{~m} 2$ e posteriormente mais $1.000 \mathrm{~m} 2$.” Segundo a mesma fonte as obras da primeira Igreja Armênia do Brasil se iniciam em 1930, em Presidente Altino e consta que temporais e chuvas paralisaram essas obras e nesse momento a Comissão Organizadora das obras “dirige-se, então, ao Patrício e Benemérito Senhor Vahram Keutenedjian, que nessa época morava em São Paulo, pedindo-lhe que assumisse a construção da Igreja. Este nobre benemérito não se furtou a esta solicitação e em pouco tempo, 1932, a Igreja ficava pronta”. Cf. Anexo (1) Histórico dos Imóveis da Comunidade Armênia de Osasco. 
"não quero homenagem nenhuma, eu só quero que vocês ponham o nome da igreja do meu padroeiro que é São João Baptista”. Sb Hovhannes Mkrtich’ em armênio: São João Batista e até hoje a igreja denomina-se "São João Batista”. Graças a esse benemérito, que eu te mostrei o busto pra você. Esse foi um grande mérito que nós fizemos aí.

Caso tragicamente curioso é o de Arsen Burbulian, que ficou conhecida como "turca da sorte” por conta de sua ocupação profissional: ler as borras das xícaras de café de seus clientes para interpretar a sorte de seus destinos. Pelas palavras do entrevistado, neto de Arsen, que foi fundadora e conselheira da "União Salmo Tsor de Presidente Altino”, os recursos para a abertura da fábrica de calçados da família vieram do ofício de leitura de xícaras. Trágico porque a personificação "turca da sorte” foi uma alcunha estritamente comercial que vingou, identificando a vítima com seu agressor, e curioso porque apagou a estória de uma trajetória que por "sorte” escapou do flagelo genocida. O processo de personificação mostra sua impessoalidade na negatividade das máscaras sociais que se consolidam na repetida realização da venda da mercadoria. Tanto faz se são sapatos ou conselhos, como tanto faz o processo social, ou a história, por de trás dos envolvidos na transação.

(Armênio Burbulhan) - Minha avó lia xícaras, não é? E como começou a se difundir isso na região, vinha até políticos de outras regiões pra: "aí eu vou ser candidato, será que eu vou ganhar, será que não sei o quê?”. Então, minha avó começou a ser conhecida “a turca da sorte”, que lia xícaras, tal. E ela fez um certo patrimônio, não é? É a coisa mais esquisita que pode se contar. Essa senhora, essa minha avó ela quando saiu da Armênia, tinha família. Ela e a irmã dela foram colocadas num paredão, no genocídio, né? E foram metralhadas e depois foram jogadas na vala comum. Da vala comum, minha avó se reanimou, ela recebeu uma bala no couro cabeludo, né? Então ela desmaiou, não morreu, mas a irmã morreu, os parentes, todo mundo lá ficou na vala comum. Ela fugiu da vala comum e fez esse caminho que estou te contando. Ela chegando em São Paulo, chegou no Brasil...sabe, ela fez o que ela sabia fazer, ler sorte, não é? Deu muita sorte pra ela na verdade, ela trazia uma mensagem, sempre a sorte você nunca fala uma coisa, lê a xícara, você nunca fala: "você vai morrer amanhã". Ninguém vai voltar, então sempre falava alguma coisa de boa sorte pras pessoas. E ela fez isso, fez isso por um bom tempo, que nem eu te falei, juntou um patrimônio até que, lá em Osasco, meus pais era os primeiros a ter pouca coisa elétrica, né? Assim, ter a primeira televisão do bairro, o primeiro carro importado, coisas assim que o contraponto da minha mãe, não tinha condição, tudo era andar a pé. Então eu acho que é assim, dinheiro pra montar a empresa foi a minha avó que cedeu pra eles, a ajuda veio da minha avó, né? É lógico que, a minha mãe sempre conta histórias de que famílias ajudavam famílias naquela época, tal. E acho que funcionou muito bem com a minha mãe isso. Tias que ajudavam, primos, a família era sempre numerosa, né? Não digo a dela, mas outras. 
O depoimento de Armênio é importante no sentido de desnaturalizar o mascate como forma exclusiva de acumulação de capitais e também para explicitar que nem todos os armênios se ocuparam da produção de calçados. Setrak, outro entrevistado da pesquisa, também aborda a “especialização funcional” (GRÜN, 1992) na produção calçadista em Altino, mas percebe-se que essa não era uma atividade que mobilizava muitas famílias, assim como os armazéns ou as “vendas”. Apresentava-se como uma opção entre outras para além do assalariamento fabril.

(Artur) - Agora, os sapatos aqui em Altino não foi tão forte, é isso? Ou tinha fábricas de sapato de pequeno porte...

(Setrak) - Tinha, tinha, tinha. Chegou a ter duas ou três fábricas de calçado forte, mas assim, praticamente artesão que trabalhava só o pessoal da família. Tinha três ou quatro fábricas de calçado, mas não conseguiam, com o tempo foram desativando.

(A) - E isso era mais ou menos que época?

(S) - Aí já era um pouquinho mais pra frente... 1950, 1955, por aí, não chegava a ser 1960. Então o que tava dizendo pra você é que não tinha estrutura, não tinha sarjeta, mal e mal você sabia onde era o seu terreno porque provavelmente a empresa, a loteadora falava: "o lote teu é esse, o lote teu é esse”... E assim sucessivamente. E eles iam fazendo com a ajuda de um e de outro, pegando dinheiro emprestado, iam fazendo a pequena casa e começar morando lá nessas casas e como o terreno era grande fazia, com o tempo, fazia uma outra casinha pra aluguel. Fazia uma outra casinha e alugava, até hoje existe algumas casas que a gente chama de cortiço porque é coisa muito grande, uma ao lado da outra, mas não tinha infraestrutura, não tinha água de rua, não tinha, não tinha...era tudo fossa séptica, não tinha lavatório, era tudo na base da boa vontade.

(A) - Então, nesse caso a pessoa tinha o terreno lá dela que era $10 \mathrm{~m}$ por 50m, construía a casa na frente e no fundo fazia um conjunto de quartos...

(S) - Isso, quando podia, exatamente.

(A) - Aí alugava esse fundo?

(S) - Agora, com isso daí, eles iam sobrevivendo. Uma boa parte trabalhou assim, mas todos, independente dos que vieram pra cá (Presidente Altino), todos tinham uma atividade de trabalho, não digo artesanal, algum ou outro fazia uma coisa diferente de loja coisa parecida, armazenzinho, aqueles armazéns... antigamente chamavam de "venda", venda e não armazém como é hoje, armazém ou empório. Eles falavam fundamentalmente era "venda" e eles foram fazendo, outro tinha bar, outro tinha isso, assim sucessivamente foram sobrevivendo.

O desdobramento desse “aluguel dos fundos” traz uma distinção social a esses proprietários nas personificações suburbanas e atualmente periféricas, quem antes personificava o imigrante proprietário apenas de sua força de trabalho passa a reunir também a renda fundiária de sua 
propriedade privada. A autonomização das fontes de rendimento vai e vem na concorrência em busca de monopólio. Interessa a pergunta sobre a diferença entre as formas de renda fundiária suburbana antes da internalização da metrópole de São Paulo e da renda fundiária periférica já nos atuais tempos pós-catastróficos da metrópole “internalizada”, bem como explorar a complexidade das personificações que envolvem os imigrantes armênios e seus descendentes. 


\section{5) Patriarcado, crédito a homens de valor}

Jeremias - disse ele. - Quero ser muito franco com você, me responda também com sinceridade a uma pergunta. Já não estamos mais na situação de patrão e servidor, sobre isso não só você está contente, mas eu também; não temos motivo, portanto, para enganarmos um ao outro.

O castelo

de Franz Kafka

Como foi apontado anteriormente, a figura de Riscallah Jorge Tahinian para a capital e a figura de Vahan Keutenedjian para o subúrbio, os armênios beneméritos da comunidade de São Paulo e Presidente Altino, parece ter sido de suma importância para a inserção econômica dos refugiados do Genocídio Armênio. A ajuda entre as famílias extrapola o âmbito da "ajuda-mútua” de Grün que é relativa à ajuda (dinheiro emprestado ou crédito em mercadorias) direcionada para criação de pequenas fábricas de calçado e entrelaça a participação na comunidade especialmente através da Igreja Apostólica Armênia que, no caso das localidades em questão, contou com apoio massivo dos dois beneméritos (entre outras figuras, como a de Sebastião Burbulhan e seu lugar na Sindicato Calçadista de São Paulo, relatado na primeira entrevista) para a construção de suas sedes. E, para além disso, na reprodução da armenidade por meio das fontes de rendimento - terra, trabalho e capital - entrelaçando a vida de armênios imigrantes já estabelecidos desde o final do século XIX e refugiados do Genocídio Armênio atrás de melhores condições.

O pagamento feito aos novos imigrantes, empregados nessas fábricas, era em grande parte com moldes de coleções anteriores, sobras de couro, etc. Por conta disso, assalariamento é para Grün, nesse caso, uma maneira “um pouco abusiva” de explicar tal relação empregatícia, uma vez que havia grande cumplicidade entre empregados (recém-chegados expropriados dos meios de produção) e empregadores. O autor afirma que o assalariamento era tido como etapa, momento na sua carreira social, que se encaminharia para sua própria confecção. Nesse período, o recémchegado ganharia experiência no ramo calçadista e teria que demonstrar que era um "bom armênio”, ou seja, qualificando-se como possível receptor de ajuda (crédito) por parte dos conterrâneos. Para Grün, esse processo foi um excelente reprodutor de identidades étnicas (1992: 47).

Desta forma, a inserção dos armênios na economia brasileira através da mobilidade do trabalho próxima às possibilidades postas pelas relações dentro da comunidade, sem esquecer da 
importância da religião cristã que também é presente caso estudado por José de Souza Martins sobre São Caetano, molda sua identidade armênia a posteriori, um processo semelhante foi tratado por Martins ao abordar os imigrantes de origem italiana em "mútuo socorro no nascimento da classe trabalhadora” no seu livro “Subúrbio”. Para este autor “a italianidade foi (...) construída na adversidade das condições de vida que o imigrante encontrou no Brasil”, em um processo de “autodescoberta do imigrante como italiano”.

Roberto Grün (1992: 54), ao tratar da imigração armênia do começo do século XX, afirma que existe uma estreita relação entre o crédito, a chamada “ajuda mútua” que acabou por conduzir a especialização funcional (calçadista) e a construção e afirmação da identidade étnica, de modo a conectar pertencimento nacional e religioso com atividades profissionais de parte dos refugiados e imigrantes. Para o autor: “essa conexão nos leva ao centro da problemática da não dissociação entre as esferas econômica, religiosa e cultural nas estratégias de carreira dos imigrantes e descendentes de primeira geração”.

Essa conexão é significativa nas primeiras fases de imigração, ainda que em nossa perspectiva ela seja demasiadamente generalista e escamoteia os processos de trabalho através de uma representação de identidade cultural unívoca. Loureiro (2012) e Grün (1992), como vimos, destacam ainda a importância da Igreja na vivência da comunidade, criando uma hierarquia que dava a possibilidade do armênio recém-chegado, sem recursos materiais, de se inserir através da “ajuda mútua” na indústria de sapatos, uma vez que uma espécie de adiantamento de capitais era concedida aos que chegavam apenas se fossem trabalhar na e com confecção de sapatos.

Outro entrevistado, Eduardo Zeronhian ${ }^{23}$, neto de imigrantes, narra a trajetória da fábrica familiar a partir de sua experiência. O início do depoimento explicita o Genocídio como "mito de fundação da coletividade armênia” no sentido de um sentimento de coesão a um grupo social heterogêneo, de modo que o Genocídio aparece como uma espécie de organizador das narrativas (PORTO, 2011: 16).

Eduardo - Ele [pai] conta que eles tiveram que vir de lá como todos imigrantes, fugido, né? Não teve jeito. Aí chegaram aqui no Brasil e cada um foi fazendo uma coisa, chegaram a trabalhar na prefeitura, meu avô antigamente era cobrador de ônibus. Foi aí que ele [pai] começou depois a trabalhar na fábrica de um primo, tio deles.

Artur - Fábrica de calçado?

(E) - De sapato. A vida inteira deles foi sapato, praticamente eles não sabiam fazer outra coisa a não ser mexer com sapato.

(A) - Mas eles mexiam com sapato lá na Armênia, não?

23 Entrevista realizada no escritório do entrevistado em 10 de maio de 2013. 
(E) - Não, lá não. Quer dizer nunca me falaram nada, né? Deles terem trabalhado com sapato lá. Aí quando eles chegaram, parece que tinha um tio, um parente do pai deles, do meu avô que mexia com isso... aí começou todo mundo trabalhar lá dentro. Aí depois ele [pai] abriu a fábrica. Com tempo eles montaram a fábrica deles...

(A) - Você diz eles, quem são?

(E) - Ele [pai] e os dois outros irmãos. Aí a vida inteira deles foi nisso, na base do sapato.

(A) - Isso quando eles começaram a trabalhar na fábrica do primo do seu avô?

(E) - Se eu não me engano era um primo do meu avô.

(A) - Isso foi mais ou menos em que ano?

(E) - Olha... que eles tiveram fábrica, pô desde que eu era criança. Quer dizer, ele era solteiro e já tinham fábrica, isso é da década de cinquenta e pouco.

(A) - A fábrica deles, né?

(E) - É, aí que eles começaram com a fábrica deles.

(A) - E era pra esses lados daqui...

(E) - Sempre foi aqui no bairro do Imirim, sempre. Eles começaram na Rua nova dos portugueses. Aí depois eles vieram pra... com o tempo meu avô construiu o prédio onde eles, o pessoal morou a vida inteira, mora até hoje que é na Alfredo Pujol. Embaixo eles chegaram a montar uma fábrica também, teve uma época que montaram um supermercado. Daí eles saíram, montaram uma outra fábrica na Avenida Casa Verde e ficaram por um bom tempo. Aí em 1981 eles compraram um terreno na Avenida Imirim, aí construíram o prédio e eles passaram a fábrica, que até então na Casa Verde era locado, pagavam aluguel. Aí aqui eles passaram pra prédio próprio. Aí depois teve aquela crise toda, em 1986, 87... Foi aí que meu pai tinha um pouco mais de visão de negócio... Ele achou melhor, porque eles ficaram praticamente e isso convivi porque eu fazia faculdade $e$ trabalhava na fábrica na época. Eu convivi, foi um ano praticamente... 1987, se eu não me engano,1988. Foi um ano assim totalmente parado o mercado. Sem trabalhar, tendo que custear funcionário pra num perder... fábrica de sapato se você dispensasse um funcionário, a mão de obra, depois pra você recontratar era difícil. E os funcionários deles, a vida inteira, foram os mesmos. Sempre funcionário de confiança, trabalhadores, que nunca deram problema nenhum pra eles. Então eles nunca... eles preferiam pagar o funcionário e ficar com os funcionários do que dispensar e depois ter que ficar correndo atrás de outros. Muitos amigos deles que tinham fábrica de sapatos na época, momento que eles não trabalhavam eles queriam catar os empregados e levar. Então nesse ponto aí foi quando ele achou, ele viu que o negócio não ia, não ia... tava ruim mesmo a crise econômica do país aí ele resolveu parar. Ele falou: 'o que eu construí hoje, se eu continuar eu vou perder, se eu continuar eu perco'. Até um dos meus tios foi contra na época, queria 
continuar. Ele [pai] falou: 'cê pode, quer ficar com a fábrica, num quero nada, pode bancar você, não tem problema nenhum, mas eu pra mim vou parar antes que eu perca. O pouco que eu construí de patrimônio, de coisa que eu comprei... eu não posso jogar por água a baixo’.

(A) - E a sua lembrança é que ele atribuía esse problema à crise do país todo?

(E) - Ah foi... tanto foi a crise que tiveram vários amigos, eu conhecia porque eu trabalhava na fábrica...então eu fazia, a gente tinha muito contato, muita amizade. Várias fábricas de sapatos de amigos que quebraram, que quebraram.

(A) - Mas essas fábricas de amigos eram todas de armênios?

(E) - Armênios e brasileiros. Tem inclusive um deles, esse é brasileiro, eu encontro ele de vez em quando aí um tempo atrás, quando eu havia encontrado...Aí eu tava comentando com ele, fazia tempo que eu não tinha visto ele, ele disse que perdeu tudo o que ele tinha, casa... tava recomeçando tudo de novo agora, por causa da fábrica, da crise.

(A) - Ele seguiu no ramo do calçado...

(E) - Ele parou, quebrou, ele falou: 'fui vendendo patrimônio para ter que ir pagando dívida, dívida, dívida, não sei o quê... mas sabe aquela coisa de 'ah, eu acho que vai melhorar, eu acho que vai melhorar', então...nesse ponto eu vou falar, meu pai foi bem inteligente porque não sei hoje como ele teria ficado se ele tivesse insistido. Porque pelo irmão dele ele continuaria, mas ele falou: 'eu não vou porque se eu continuar...'

(A) - Aí ele vendeu?

(E) - Não, ele fechou. Venderam todas as máquinas, venderam todo equipamento e parou.

Nota-se, a partir da fala de Eduardo, que de fato o ramo dos calçados, pelo menos na pequena escala e na época em que eles produziam, era de baixa composição orgânica de capital, o que mais tarde tornaria inviável a reprodução deste tipo produção com o estabelecimento das grandes marcas brasileiras a partir da década de 1970. Posteriormente, ao final da década de 1980, com abertura da importação no governo Collor, a produção calçadista de pequeno porte é extinta.

Outro ponto interessante abordado pelo entrevistado diz respeito ao modo como seus familiares se inseriram no mercado de trabalho, sua mobilidade. No primeiro momento trabalharam em empregos variados em que não havia necessidade de especialização para depois serem mobilizados por outros familiares na pequena indústria calçadista. Neste caso há ainda o desdobramento de uma nova “fábrica armênia” a partir da chamada “ajuda mútua” que condicionou materialmente a chamada “especialização funcional”.

O ramo dos calçados é tido como de baixa composição orgânica de capital (pelo menos nessa época) e deter os meios de produção era a principal barreira aos recém-chegados. Através da “ajuda mútua” essa entrada no ramo dos calçados era facilitada. 
De posse dos moldes, o agente passava a montar sapatos por conta própria em casa, após o trabalho e/ou com ajuda da família. Com o tempo, essa pequena produção doméstica virava uma 'fabriqueta de fundo de quintal' e os mais capazes, os afortunados, transformavam a fabriqueta em fábrica regularmente estabelecida. (Grün, 1992: 48)

Os insumos (borracha, cola, salto, linha) eram fornecidos em forma de crédito em mercadorias pela Casa Bóia, propriedade de Riskallah, em forma de “caderneta de conta corrente”. Dessa forma, o armênio que se instalava no ramo dos calçados deveria estar ligado à comunidade, em especial à Igreja e a nomes bem estabelecidos economicamente.

O autor supracitado apresenta o exemplo de uma família que já tinha experiência com ofício e confecção têxtil no Líbano e que na chegada ao Brasil contou com o apoio (empréstimo de máquinas, adiantamento de tecidos) por parte da família Gasparian. Passados alguns anos, depois de pagar suas dívidas e gozar de alguma estabilidade, essa família se insere no ramo dos calçados ao invés de se manter na indústria têxtil. A força da chamada “especialização funcional” nesse caso é pensada por Grün em três pontos: primeiro pelo fato de que no ramo de confecção têxtil os armênios se defrontariam com os judeus e árabes enquanto concorrentes; em segundo por serem minoria nessa atividade e portanto terem menor possibilidade de serem ajudados; por fim, justamente a respeitabilidade dos Riskallah e o maior aporte de capitais no ramo calçadista entre os armênios. Nas palavras do autor:

(...) o ramo de sapatos pode ser considerado um mercado mais aberto, em que as posições já mantidas pelos patrícios facilitam as manobras comerciais de todos os armênios, que podem se movimentar entre as diversas fontes de apoio possíveis; enquanto, em outro ramo, o agente isolado, material e culturalmente, fica a mercê de seu patrocinador imediato. (GRÜN, 1992: 58)

O condicionante cultural é considerado pelo autor como mais relevante no seu esquema explicativo, uma vez que os recém-chegados, ainda que tentassem, tinham muitas dificuldades para se estabelecer sem depender da ajuda dos conterrâneos que aparece como possibilidade de se “movimentar entre as diversas fontes de apoio”. Esse condicionante pode ser elaborado para além da perspectiva cultural, como uma forma específica de inserção econômica desses armênios, datada por um contexto histórico em que o avanço divisão social do trabalho, mesmo que lento ou “intermitente” como aponta Oliveira (1977), dava o tom de uma dinâmica nova de acumulação de capitais no Brasil. Nesse sentido que a mobilização de imigrantes europeus para o trabalho constituía a primeira opção da indústria brasileira, apesar da abundante população brasileira liberada para o capital desde a Abolição ${ }^{24}$.

Com o fim da ordem escravocrata na República Velha (1899-1930), a passagem para o trabalho livre altera as condições e custos da produção do café. Esse processo coloca na mudança da 24 Aqui cabe uma consideração sobre uma insuficiência deste estudo, que também reflete uma escolha. Ao longo de nossa exposição nos aproximamos da ideia desenvolvida por Marx sobre superpopulação relativa sem explicitá-la nesses termos. É sabido que há uma vasta discussão acerca da população na Geografia, que vai desde a surrada teoria de Malthus e sua influência na demografia quantitativa a autores clássicos como, La Blache e a modo de vida, Max Sorre e a noção de mobilidade do ecúmeno, Raffestein e as Leis da migração, entre outros. Para uma boa revisão introdutória acerca dos estudos de população na Geografia, recomendamos a publicação de DAMIANI, 1992. 
forma de produção dos meios de subsistência a possibilidade de um modo de produção de mercadorias interno. Nesse movimento há uma diferenciação da divisão social do trabalho, pois nem as unidades agroexportadoras nem a chamada agricultura de "subsistência" vão produzir tais mercadorias. Esta mudança nas relações de produção e as contradições para a diferenciação da divisão social do trabalho colocaram a centralidade econômica na intermediação comercial e financeira feita pelo Estado. As divisas vêm da comercialização dos produtos da agroexportação que no câmbio em libras deixam à margem um sistema financeiro-monetário interno.

Emitindo dinheiro, o governo busca a desvalorização cambial, o que temporariamente reduz o custo do capital-dinheiro interno, possibilitando a realização do valor das mercadorias internas e o consequente aumento nos níveis de formação de capital interno. Resulta dessa política a elevação do preço dos produtos de importação.

Após esse momento, o governo inverte a política e retoma o financiamento quase que exclusivamente externo. Oliveira aponta para uma "estrutura contrapontística” em que se altera a política cambial e a intervenção financeira e comercial. Com isso, a formação interna de capital e o avanço da divisão social do trabalho se desenvolvem de forma intermitente. A diante da Revolução de 30, a valorização do café devido seu desenvolvimento a partir do financiamento externo permite o financiamento interno. Investimentos em infra-estrutura de ferrovias e portos se fazem com capital estrangeiro, aumentando substancialmente a composição da dívida externa e influindo na taxa de câmbio. A melhoria na condição dos transportes significou um aumento da produtividade agroexportadora, aprofundando a “vocação agrícola” tendo no café seu principal produto.

Mesmo com o aumento da massa de valor produzida em mercadorias havia um “descolamento” entre produção e realização do valor, gerando “extrema gravitação nas finanças governamentais”. As dívidas aumentam muito nesse período e as flutuações de oferta e demanda enfraquecem o poder de negociação do Estado ante seus credores externos. Mais dívidas são feitas e o Estado recorre à desvalorização dos mil-réis, ampliando a dívida interna com a emissão de papéis de dívida pública:

Nessas condições extremas, o Estado criava a intermediação financeira interna e abria o passo à concretização da diferenciação da divisão social do trabalho interno mediante um reforço à realização do valor das mercadorias internas (OLIVEIRA, 1977: 21-22).

A economia da Colônia alimentou a acumulação primitiva na Metrópole, mas seu efeito interno era o impedimento da diferenciação e avanço da divisão social do trabalho. Esse tipo de economia acumula riqueza (terra sem renda e escravos e sua subsistência como capital constante), mas não capital. Nesses termos, a divisão social do trabalho até o século XIX será insignificante e incapaz de transformar qualitativamente os padrões de acumulação e crescimento. 
Voltemos à passagem em que Abolição e o trabalho livre colocam a possibilidade de um modo de produção de mercadorias interno para dar conta da reprodução da força de trabalho. Nas cidades, a separação entre os produtores e os meios de produção cria e faz crescer "uma população para o capital”, reforçando o potencial de acumulação. Entretanto a modernização retardatária (Kurz, 1992) coloca alguns entraves a esse potencial. A ausência de capitalização anterior coloca um nível muito baixo das forças produtivas e a força de trabalho liberada "nada tem a transferir senão sua força muscular” (Oliveira, 1977: 26). Por esses e outros motivos que, a despeito da abundância de força de trabalho, a indústria brasileira até as primeiras décadas do século XX vai recorrer ao imigrante estrangeiro, “cuja predominância no total da classe operária ainda era absoluta em 1920.”

Dentre as muitas reconfigurações oriundas das novas relações de produção, que altera a relação campo-cidade, está o avanço da divisão social do trabalho nas cidades. Nesse ponto Oliveira aponta para uma simultaneidade entre industrialização e urbanização, as chamadas “cidades dentro das fábricas”. Porém, a acumulação pela indústria na República Velha é lenta e intermitente, repercutindo em um mercado regional e estanque; mercado nacional integrado somente na metade da década de 1950.

Estas condições farão com que o avanço da divisão social do trabalho pautada na indústria acompanhe, principalmente, a demanda da reprodução da força de trabalho. Para Oliveira o custo de reprodução do trabalhador manter-se-á baixo pelas relações de produção em expansão no campo e pelo “exército industrial de reserva”:

Os poucos itens não agrícolas da cesta de consumo dos assalariados imporão um caminho à
industrialização nascente: ela começará pelos bens não duráveis, tipo alimentos, calçados, têxteis,
e alguns bens intermediários para os quais a existência de recursos naturais no País, os altos custos
de transporte da importação e o consumo da mão-de-obra barata os tornarão competitivos
(principalmente no ramo de minerais não metálicos). O tamanho das empresas nesses ramos não
será insignificante, principalmente a têxtil, dada a dimensão do mercado constituída por uma
massa de valor (a folha de salários) de baixo nível, é certo, mas extremamente extensa. O sentido
geral da industrialização seguirá, de perto, pois, os níveis, a composição e as modificações no
custo de reprodução da força de trabalho; a demanda das classes médias, débeis tanto numérica
quanto qualitativamente, bem como da burguesia agrária e urbana, continuará sendo atendida pelas
importações (OLIVEIRA, 1977: 27, grifo nosso)

O lugar da produção de calçados como um bem não durável se faz importante para pensar a reprodução dos armênios nesse ramo da indústria, tanto pela demanda posta pela reprodução da força de trabalho que crescia em São Paulo quanto pela baixa composição orgânica de capital das pequenas fábricas de armênios e descendentes que conseguiram reproduzir ampliadamente a armenidade.

A segunda geração, ou filhos dos imigrantes que chegam nesse contexto da Primeira República, eram logo iniciados ao trabalho ligado à família. Esses teriam mais habilidade para lidar com clientes e especialmente com o Estado brasileiro ou mais especificamente o paulista, que 
aparece personificado na figura do fiscal. Introduzir os jovens nas lojas e fábricas era também um jeito de garantir a reprodução dos negócios, evitando que a segunda geração mudasse de ocupação. Para Grün, na terceira geração, as classes altas tornam-se referência.

A transmissão da chamada “especialização funcional” é alta entre as gerações, estruturando as formas de sociabilidade mais puras da colônia (ligadas à Igreja, Escola Armênia, etc.). Caminhando em busca de uma resposta o autor destaca, por meio de citação de entrevista, a iniciação precoce no ramo dos calçados como algo que reflete a estrutura familiar armênia, em que os jovens começam a freqüentar a loja, firma de calçados e as garotas após os estudos passam o dia ajudando a mãe em casa. As típicas relações do valor-dissociação (Scholz, 2016) se reproduzem com naturalidade no seio da família armênia imigrante calçadista. Para Grün (1992), os mecanismos de reprodução dessa especialização funcional são próprios aos grupos que encontram dificuldade de reproduzir suas particularidades em um contexto de mercado aberto (1992: 60).

Com a influência das ideias liberais que retornam ao cenário do pensamento políticoeconômico no final do século XX e a disputa pelo mais alto lugar na hierarquia econômico-social, o cenário de inserção comercial da terceira geração se altera:

(...) a figura do negociante intrépido é valorizada, não se trata simplesmente de inverter o sinal da antiga desconfiança que a sociedade depositava no comerciante, mas de um novo tipo de empreendedor ungido por um diploma superior, que faz da Administração uma arte nobre. Com a iniciação precoce, o período de turbulência do adolescente armênio acaba sendo "canalizado" no negócio (negando o ócio...). Mais do que isso, as formas de socialização que se desenvolveram nesse processo ajudam a atualizar as posições da família em relação à translação e evolução geral no campo econômico. (GRÜN, 1992 : 61)

Agora, esses jovens tendem a procurar uma clientela de alto nível social, passando do centro da cidade para os Jardins, ou mais especificamente aos shoppings centers; essa é mais uma diferença geracional que acompanhou as mudanças econômicas da cidade. O autor aborda como a “armenidade” fica comprometida ${ }^{25}$ quando os estudos universitários e casamentos inter-étnicos tornam-se mais comuns, juntamente ao fato de que o circuito calçadista não tinha mais como base as coalizões étnicas.

Pensando os mecanismos da reprodução étnica, Roberto Grün (1992) busca compreender na subjetividade dos jovens armênios quais são as motivações de sua inserção na "maioridade comercial” e aponta para o trinômio: dinheiro no bolso, carrão e loja no shopping.

25 Eduardo, um dos entrevistados, deteve-se bastante nas suas lembranças de infância e adolescência no Clube (SAMA). Ele afirma que na década de 1970 o clube era muito movimentado e hoje está vazio. Em um primeiro momento ele fala sobre essa diferença, atribuindo às mudanças na vida, turma da faculdade, filhos. Posteriormente fala sobre "panelinhas" no clube e que os jovens deveriam tentar reanimar o clube. Perguntado se ele conseguia apontar para um fator que explicasse essa diferença entre “a sua época” e o clube esvaziado hoje, Eduardo afirmou não ter uma resposta. 
Dentro do universo cultural em que o sapato e sua comercialização são referência na socialização (Escolas Armênias, Igrejas e Clube), dinheiro no bolso aparece como "tentação" ao jovem na medida em que o destaca diante dos outros jovens. Nesse ponto, alternativas carreiras universitárias deixam de ser uma possibilidade de inserção social e a posição do comerciante passa a ser exaltada, opondo-se a mentalidade do homem de ação que caracteriza simbolicamente o comerciante ao homem reflexivo referido às carreiras universitárias ou dessa ordem de formação.

Nosso entrevistado conta sobre essa mudança de carreira da segunda para a terceira geração, da fábrica de calçados para uma profissão liberal que exige formação superior, demonstrando que o trinômio citado por Grün é uma realidade relativa às famílias que já tinham a inserção no comércio do shopping:

(Artur) - E você decidiu ir pra outra carreira?

(Eduardo Zeronhian) - É, na realidade ele [pai] sempre falava que ele não queria aquilo pra nós, pros filhos. É um ramo difícil, é sacrificante, é complicado, você não sabe o que isso vai girar amanhã. É difícil, ele falava: "vão estudar, vão fazer outra coisa". Então cada um, na verdade o único que trabalhou na fábrica fui eu, meus irmãos, um foi na área da engenharia, outro em administração, sempre trabalhou em banco. Então quem ficava na fábrica, trabalhava mais lá era eu.

De acordo com outro informante da pesquisa, James Onnig Tamdjian, geógrafo que hoje integra a direção da Sociedade de Artística de Melodias Armênias (SAMA), conhecido como Clube Armênio: “a indústria calçadista armênia é um retrato fiel da descentralização industrial em São Paulo”, isso por conta da elevação dos salários (capital variável) na capital em relação com outros pólos calçadistas emergentes e também pelo aumento do capital constante por conta da elevação do preço dos aluguéis na cidade. De acordo com Tamdjian, a inserção dos refugiados tem uma característica piramidal, em que os recém-chegados ancoram-se nas famílias ricas que já estavam em São Paulo ao empregarem-se. No topo da pirâmide os armênios capitalistas que empregam os primeiros refugiados, estes formam o meio da pirâmide; na base a "massa", os imigrantes que chegaram entre as décadas 1920 e 1930. Nosso informante entende que a participação comunitária é maior na base dessa estrutura piramidal que ele se refere. Com essa informação o argumento ganha processo e movimento para se pensar o que coloca Grün (1992) sobre a inserção dessa "massa” na comunidade, sobre aprovação do “bom armênio” como reprodutor de identidades étnicas.

Acerca da ocupação profissional e sua relação de gênero dentro da típica reprodução da família armênia imigrante calçadista, diz o autor de Negócios e Famílias:

(...) entra no contexto a definição dos papéis sexuais, vinculando as condutas masculinas à loja, que significam a ação e o mundo exterior, enquanto o papel feminino se vincula às leis reflexivas, à domesticidade (enquanto a menina fica em casa estudando, o menino vai ajudar o pai...). Cria-se dessa forma um composto de significados vinculando a definição de homem completo à definição de empresário (GRÜN, 1992: 64) 
Expressão mais clara do trabalho abstrato como princípio masculino não poderia ser dita pelo autor ao caracterizar a "definição dos papéis sexuais”, separando a "esfera feminina e as qualidades imputadas às mulheres”, que “representam somente o outro lado da moeda do "trabalho abstrato' no patriarcado ligado à forma-valor”, como escreveu Roswitha Scholz (1996). A armenidade que aparece como cultura e tradição trans-histórica cai como uma luva na sociabilidade patriarcal capitalista. O que aparece como natureza da relação interna a essa comunidade não é outra coisa que a natureza da relação do valor-dissociação, apenas com cores culturais particulares a serviço da identidade dos participantes dessa sociabilidade comunitária particular.

Carrão é uma continuação da ideia de formação da maioridade que carrega simbolicamente uma imagem de riqueza, potência e independência, novamente somente ao homem enquanto sujeito do valor. Por fim, loja no shopping indica a permanência modernizada dos armênios no comércio, em que a elevação social se coloca com a necessidade de inserção em círculos de sociabilidade além da fronteira étnica. Nessa afirmação comercial que aparece como “gosto pelo negócio” em um momento de predomínio de ideias neoliberais, os “descendentes de imigrantes expandem-se para as classes médias e altas em geral, da mesma forma que se expandiram em outros tempos os elencos de qualidades necessárias ao 'bom funcionário'”(Grün, 1992: 66).

A investigação feita no item "suburbana armenidade” tentou apontar para contradições no esquema explicativo de Roberto Grün entre “vocação rural” e “vocação agrícola”, bem como para as personificações dos imigrantes armênios que vai além da ocupação calçadista. No entanto, podese dizer que o crivo de “ajuda-mútua” para "bons armênios” confere aos portadores dos capitais, os assim chamados beneméritos da comunidade - da mesma maneira aos armênios donos de capitais e empresas ou representantes sindicais que contavam com todo apoio das instituições da comunitárias - o lugar social do patriarca que dá crédito aos homens de valor. E a esfera privada da reprodução cabe às mulheres armênias com suas “virtudes femininas” (Kurz, 2000) dissociadas da produção de valor. Desta feita, a identidade cultural armênia - que esconde relações de dominação entre classes, tal qual esconde a dominação patriarcal do valor-dissociação - cabe tanto aos beneméritos quanto aos refugiados, mesmo que suas personificações e condições econômicas sejam completamente diferentes. Se o primeiro participa do elo cultural a partir de sua vantajosa rede de exploração de trabalho e concessão de crédito dentro da comunidade, o segundo prende-se nesse mesmo elo ao mobilizar sua força de trabalho para pagar o crédito e/ou para valorizar o capital dos beneméritos e empresários, os patriarcas da armenidade na metrópole paulistana. 


\section{6) Entrevista com Hampartsum Moumdjian}

\section{I) Sobre a América, giavour e como fazer amizade sem documentos}

(Hampartsum Moumdjian) Então vamos começar a falar do Senhor Manuel Gureguian. Era um jovem 18 anos quando, com 12 começou o massacre dos turcos lá na Cilícia e eles foram expulsos de suas casas. Mataram os familiares e ele se encontrou sozinho com as caravanas que saiam deportando. E chegou ao Líbano, lá esteve alguns anos, 2, 3 anos. Quando soube que tinham barcos para que saíam para América, América! Para eles América era outro mundo, era a salvação deles. Ele deixou, vamos chamar assim, a namorada, a noiva no orfanato do Líbano, orfanato de meninas, era um orfanato dirigido por americanos e que tinha escola industrial $e$ aprendeu fazer, ela, aprendeu fazer tapetes bordados. O Manuel pegou um barco: ' - onde vai?' Chegaram a Marselha, ele sabia francês ficou lá e o mais prático era trabalhar no porto, carregador. Até que um companheiro árabe xinga ele, dizendo: “você é giavour”. "Giavour”, para o árabe muçulmano é infiel. Então, para um armênio é um palavrão, isso que "você é giavour”. Ele disse: "eu tinha um gancho na mão que usava para levantar os fardos e rasguei a cara dele, brigamos e o patrão nos mandou para a rua. Perdi documento, perdi tudo e agora?” Então, (Manuel) tava morando lá no porto, passou outro barco: “- Onde vai? - Para América.”. Então procurou um casal, simpatizou por um casal que não tinha filhos. "Vocês me levam? Eu quero ir ao Brasil." (O casal respondeu) "Sim”. De dia ele descia na cabine e de noite eles (o casal) ocupavam a cabine e ele subia em cima do barco. Aí nas barcaças de salvamento ele se escondia. (Artur) Então ele veio ilegal?

(H) Ilegal. E agora, quando cruzam o Equador (a linha) fazem um reconto de passageiros. Em uma, deu no colo dele uma criança, ele passa o documento da criança. "Tem documento?” Quantos seriam? Duas mil pessoas? Então conseguiu passar. E na outra vez que fizeram também um levantamento de passageiros tinha falecido uma pessoa, eu não sei como ele consegue esse documento e passa com o documento. Quando chegam ao Rio, o casal que trouxe disse: "Bom, já estamos no Rio, estamos no Brasil você vai descer”. (Manuel): “Não, eu tenho medo”. Discutiram, conseguiu ficar no barco e chegou a Santos. Quando chegou a Santos, quem conta é a pessoa que trouxe ele, que eu conheci em Montevidéu. Disse: “eu peguei o chapéu de palha que ele tinha, joguei no cais. Olha vai, pega teu chapéu e te vira. Depois daqui temos Montevidéu e lá é mais severo o controle." Aí desceu, pegou o chapéu e subiu para São Paulo. A cá se encontrou com muitos armênios que também tinham vindo...isso aconteceu, que estou contando, em 1928 tá acontecendo isso. Agora não me lembro o nome do barco que trazia, mas que ele se lembrava tudo, 
dia tal, barco tal. Muito bom. Estando aqui em São Paulo, ele fazia mascate, comprava, vendia como todos os armênios fizeram aqui. Aí ouve que tem Buenos Aires, "lá tem mais armênios, na Argentina, porque não vai para lá, eu vou para lá?” Pega um trem vai para o sul. Em cada cidade que para ele desce, olha e quando chega a Porto Alegre se encontra com outras pessoas também assim como ele, sozinho e eram árabes, eram de Líbano. Então fez simpatia, amizade e ficou (em) Porto Alegre, gostou da cidade. Depois de dois anos ele voltava a São Paulo, manda dinheiro para a passagem para a noiva, vem a moça, casam em São Paulo e vão para Porto Alegre. Esqueceu Buenos Aires e ficou em Porto Alegre. O primeiro trabalho que ele fez, lá tem, tinha nos anos 1960, 1970...a única galeria em Porto Alegre era a galeria Chaves que corta um quarteirão, de Rua da Praia até Rua da Alfândega. Numa das portas ele pega uma banqueta, uma mesa e começa a vender pentes, barbatanas e coisas assim. Ele conta que ao pouco tempo outro pôs lá do outro lado da porta, a porta é larga da galeria, e aí ele brigou: “não, você não pode ficar aqui”. Brigaram e foram à polícia. Ele era uma pessoa muito simpática, cativava, conversava. Ele tinha documento, disse: armênio nascido em Yerevan. Como não tinha nada, fazendo amizade com pessoas que passavam continuamente por lá, pela galeria fez amizade com pessoas que tinham cargos públicos, deputados e coisas. E aí conseguiu por intermédio de amizade deter o documento novo e que indica que ele é armênio nascido em Yerevan, Armênia.

(A) Sim, mas não era...

(H) Lógico, mas para ele era o máximo. Porque naquele tempo, armênio ter documento e dizer: nasceu em Marash, Turquia era uma afronta, era uma coisa que ninguém queria. Tanto que no ano 1918 apareceu esse diplomático norueguês Frederik (o nome correto é Fridtjof) Nansen que o projeto dele é um passaporte Nansen para pessoas apátridas. Ele fez muitos benefícios com isso, pra muita gente até aqui. E você conversa com o professor Hagop Kechichian, ele diz: “eu tenho meu passaporte Nansen.”

(A) Ah é?

(H) Quer dizer que até aqui chegaram pessoas com o passaporte, assim, internacional para os que não tinham documentos.

(A) No caso do Manuel, ele não tinha o passaporte Nansen?

(H) Não. Ele depois, lógico, tirou carta cidadania brasileira, ele ficou em Porto Alegre. Depois ele, na galeria Chaves, não sei como foi, conseguiu um lateral, uns 10, 12 metros, fez um balcão e começou a vender bijuterias e coisas que se vendem em galerias. Perto do fim da linha do bonde que estava a Praça da Alfândega, o bonde vinha, dava a volta e seguia. E ele ganhou muito dinheiro. Era um homem que se virava. Teve cinco filhas e um filho, eu conheço ele porque eu casei com a filha maior. Depois ele alugou outro local no centro dessa mesma galeria, que tinha uma 
'rotonda', tinha salões, locais. Ele tinha aí a Casa Armênia, vendia roupa interior tanto homem, mulher, camisa e bijuterias. Ele conseguiu fazer o filho engenheiro, construíram dois prédios. Se você passa pela esquina na Praça: Edifício Armênia...(risos) ele era, tanto ele como filho, ele ensinou patriotismo aos filhos. E assim, depois lá no ano 1980 a esposa faleceu de câncer e ele já vendeu as lojas. E como eu, eu sou uruguaio. Porto Alegre é a primeira cidade, primeira capital de Estado em Brasil é Porto Alegre, então a gente ia sempre, era 800 quilômetros era fácil de ir de carro e aí conhecia a filha. E casamos depois de estar quinze anos em Montevidéu, decidimos de ir mudarmos para o Brasil. Então estive um ano em Porto Alegre, representando um curtume de Uruguai, vendendo couros e você conhece Jonig Semerjian?

(A) Não.

(H) Jonig, hoje presidente do clube.

(A) Não, não conheço pessoalmente não.

(H) O pai dele me viu, me encontrou numa feira de calçados, me disse: "bom, você não quer ir à São Paulo? Nos temos lugar para você na nossa fábrica." Então ele me trouxe para São Paulo e eu fiquei aqui. Depois veio a família, tudo junto

\section{II) Sobre calçados, massacres, território e propriedade}

(A) Trabalhando em calçado?

(H) Calçado. Em Montevidéu, nós tínhamos fábricas de formas de calçados, mas aqui você não precisa fábrica de formas...começando fazer 1 par, 2 pares por dia e aí graças a Deus foi...e assim foi. Armênios como o Manuel, a história se repete em cada armênio que veio. Se você vai contar na mão que armênios que vieram com dinheiro, os dedos sobram...sobram. Se você vai aqui, como eu conheci a camisaria Nasarian e falando com o dono, to falando no ano 1957, "vocês como vieram da Cilícia, da cidade de teu pai?” “Ah, meu pai era uma pessoa esclarecida, sabia que ia haver uma guerra, éramos cinco jovens nos mandaram para América”. Eles vieram, desceram em Montevidéu e a pé, fazendo mascate, comprando, vendendo mercadoria, compraram um cavalo, depois dois cavalos e depois seguiram a cavalo até chegar a Porto Alegre e depois a São Paulo. Está os Keutenedjian, têm quatro, cinco famílias conseguiram no ano 1895 mandaram os filhos.

(A) Fugidos do massacre?

(H) Não viram o massacre.

(A) O massacre do Sultão (Abdul Hamid II)...

(H) Massacre do 1915, porque... massacre dos armênios, a Turquia não quer reconhecer porque o termo genocídio foi, vamos dizer assim, foi aceito na ONU no ano 1948. Um trabalho realizado por 
um rapaz, um homem judeu austríaco, Raphael Lemkin que conseguiu na ONU o termo de genocídio para matança de povos. Como o termo genocídio envolve restituição de bens...

(A) Território...

(H) Propriedade... e é por isso que a Turquia não quer aceitar porque seria, hoje para eles, algo desastroso. Só para te dizer: 09 de junho de 1909 decidiram matar os armênios da cidade de Adana, trinta mil armênios. Tiraram quinhentos presos da penitenciária, entre turcos assassinos e curdos, e davam ordem: "você e você vai por essa rua mata os armênios, tira o documento e pede a conta bancária. Importante porque nós já limpamos a conta deles no banco e que amanhã não venham a reclamar de que 'o meu dinheiro que deixei no banco'. Então você tira o documento de identidade e conta bancária para limpar a história deles.” Em trinta dias mataram trinta mil armênios na cidade de Adana.

(A) Dizem que os armênios que estavam em Adana eram ricos, comerciantes...

(H) Sim.

(A) Na verdade quem tava naquela faixa da Cilícia eram armênios que a literatura chama de “prósperos”...

(H) Todos os armênios, de todas as cidades eram pessoas destacadas. O armênio sempre foi, sempre, a vida armênia, do armênio é Igreja, Escola. Igreja, Escola seja da Igreja Apostólica Armênia ou Evangélica Armênia, sempre Igreja e Escola. Então era muito importante a escola para os filhos e o que aconteceu lá pelos anos 1800 e tanto, o armênio que tava numa posição boa na Cilícia, nas cidades de população armênia na Turquia, mandavam seus filhos a estudar na Europa. E eles voltaram de lá... “mas, pai, você está fazendo assim, hoje não se ara mais assim. Hoje tem ferramentas.” Ao mesmo tempo voltaram politizados.

\section{III) Sobre slogans, nacionalismos e a sovietização}

(A) Da França, não é?

(H) Como? O preceito de Igualdade, Liberdade e Fraternidade. O slogan da França? Eles ficaram impressionados com aquilo e quando voltaram e vendo o que eram na Turquia, eles não podiam...e são esses jovens passaram para a Armênia e foram os que comandaram a primeira Independência da Armênia no ano 1918.

(A) 1918 a 1920, não é?

(H) É. Só que foi uma situação um pouco rara. Tinham três países Azerbaijão, Geórgia, Armênia. Se a Confederação de Estados Independentes. No ano 1917 Azerbaijão declarou sua 
independência, Geórgia declarou sua independência e os armênios ficando sós eram um pão fácil de comer para o turco. Os turcos avançaram e naquela batalha de Karabakh...

(A) Sim.

(H) Que foi a última batalha de armênios contra os turcos e que os armênios conseguiram expulsar os turcos. E passaram ao outro lado do Rio Araks. Perderam, lógico, os Estados de .... ${ }^{26}$., que eram muito mais que o território que ficou de Armênia, $30.000 \mathrm{~km} 2$. Eles se forçaram a declarar a independência para ficar com um Estado e não ficar um território sem quem dirija. Mas naquele tempo já estavam o exército soviético na Armênia. "Nós estamos aqui, quando vocês precisarem..." e depois de dois anos os turcos começaram a preparar-se para invadir a Armênia. Aí que o governo de Armênia, depois de uma ano e meio, dois anos de independência, pede auxílio à União Soviética, sovietiza o país, perde a independência porque quando entrou na URSS perdeu a sua individualidade, independência... mas tiveram 70 anos de paz e prosperidade. Nunca, sob nenhum regime, o armênio ia conseguir o que se conseguiu nos 70 anos e vou te dizer: os últimos anos da URSS, depois do ano 1985, 1986 começaram a declinar a URSS e no 1989 foi que caiu o regime e aí cada um se vira como pode. Esta história que te contei de Manuel é um símbolo do que o armênio é capaz de fazer. Sozinho no mundo, formando família mas nunca perdeu a sua identidade, sempre com a aquela ilusão que "um dia vou à Armênia." Manuel foi no ano 1981 com um grupo, eu fui no 1980 e ele foi no 1981. “Ah, eu quero ir ver” e lógico que o armênio que fica sonhando de uma Armênia, quando vai lá à Armênia é outra coisa, não é... porque a URSS mantém o povo, mas o conceito de individualismo é pavoroso. Sempre teve sistemas, como se chama? Abuso de poder, sempre tiveram isso. Eu acho que essa é a mesma situação dos 15, 16 países que formavam a URSS que arrebentaram com a URSS. Porque Moscou não aguentava mais. Contudo, o armênio deve ter sido o povo mais astuto, mais inteligente. No ano 1965 construíram o monumento de Tsitsernakaberd, do genocídio dentro da URSS. URSS se dava bem com Turquia.

(A) Só nessa altura, né? Historicamente nem tanto, né?

(H) Em negócios...

(A) Ah, sim...

(H) Problema de guerra. A Turquia se dava bem com tudo que tinha vantagem. O armênio que voltou de Europa influenciou todo mundo lá sobre as ideias e ao mesmo tempo os armênios tinham muitos jovens brigando no exército turco. Mas o turco sabia que também tinham armênios no exército soviético e se um dia a URSS invadisse a Turquia, os armênios iam passar todo pro lado, porque a Armênia tá dentro da URSS. Eles sabiam e eles algumas vezes falaram: "nós matamos os

26Em 1918 A Armênia proclama sua independência após vencer as batalhas de Sardarabad, Bach-Abaran e Karakiliná contra os turcos. 
armênios porque os armênios estavam com o lado do exército russo que estava querendo nos invadir." Mas tudo era a insegurança do turco, de si mesmo em capacidade, contra o armênio. No ano 1910 Komidas Vartabed formou um coral de quatro vozes, misto. (Era a) primeira vez misto em Istambul e dão um concerto num teatro, no qual estava toda a plana superior do governo turco, Talaat, Enver...e quando terminou o concerto alguém ouviu dizer a Talaat: “se esta turma deixamos em liberdade, em dez anos dominam Turquia.” (risos) O armênio tinha capacidade. Todo comércio, agricultura, todo estava na mão de armênios. Se te contam a história do Musa Dagh...é outra história fantástica

(A) Tem o romance (Os quarenta dias de Musa Dagh de Franz Werfel), né?

(H) Isso é outra história...(risos) outro dia. Mas vou te dizer...ontem estive com uma senhora Hajenti Varvarisa Nercessian, tem 84, 85 anos. Você se senta e fala: "escuta, me conta como foi a vida de vocês, o que aconteceu, como saíram de Hajin?” Te conta tudo até "era dia quinta-feira, estava chovendo, tinha sol". A mulher se lembra de tudo, te conta e cada vez são menos pessoas que ficam. Eu te posso contar, graças à Deus.

(A) Sim, sim...que bom!

\section{IV) Armênios, mascate e a montanha de Santana}

(H) Porque eu gosto de ler, faço tradução de armênio ao português e aí você tem para teu material de tese um armênio entre tantos. Os armênios que vieram a São Paulo ficavam primeiramente no ano 1926, 27, 28 até 1930 no Mercadão central. Na 25 (de março), rua Pajé, Barão de Duprat...

(A) “Mascateando”, fazendo mascate?

(H) Tudo. Prédios de quatro, cinco andares, todos armênios. E coisas lindas. Fora disso, Parsekian tinha um atacado de meias na (rua) Barão de Duprat, “arco-íris” (nome da loja), três irmãos, dois irmãos. Ele conta uma vez assim, em reunião: "no ano 1928, 1930 a carroça mais enfeitada era do Semerjian que levava do Mercado (central) mercadoria para Santana." Por quê o armênio foi à Santana?

(A) Eu ia te perguntar isso. 
(H) Já te contei. Você fica donde está a Igreja Armênia, o Monumento (dos mártires do genocídio na Avenida Santos Dumont) e olha, (avenida) Santos Dumont desce...você, não veja os prédios, imagine-se, quando no ano 1930 eles (os armênios) viam uma descida e uma subida. E Santana era um morrinho, se lembravam da terra deles que era muito montanhoso e iam todos a morar em lugar alto.

(A) Então até 1930 mais ou menos eles estavam mais no centro.

(H) É.

(A) Mas quem foi pra Santana se estabeleceu no calçado, não foi?

(H) Calçado. Por quê? Porque nos orfanatos também para os rapazes ensinavam sapato, que era fácil de aprender, fácil de fazer. Meu pai em Montevidéu, quando chegou no ano 1928, eles lá no Líbano, depois que saíram de Zeitun ${ }^{27}$, faziam tapetes, tear. Por quê? Porque as pessoas sentavam no chão e a cá, não, a cá sentam em cadeira. Então ele comprou uma tábua, começou a cortar e fez cadeiras para usar. O armênio sempre se ubiquou, se ambientou no âmbito em que eles estava, sempre conseguiu.

Eu gostaria que quando você terminasse esse trabalho, me desse uma cópia para ver como ficou.

(A) $\operatorname{Sim}$, sim

\section{V) A montanha de Moisés e a resistência recontada}

(H) Não sei se te contei, você conhece a história “quarenta dias de Musa Dagh”?

(A) Do Franz Werfel.

(H) Franz Werfel...esse foi o

(A) A resistência, né?

(H) Suíço, austríaco, norueguês, não sei o quê que ficou, pegou a história...

(A) Eu comecei a ler o romance, não cheguei a terminar mas eu estou na metade.

(H) Um jovem termina o seminário evangélico de Marash, casa, 22, 23 anos e mandam para Zeitun a dirigir uma igreja. Ele foi lá, em seguida conseguiu se encaixar na autodefesa de Zeitun. E era 27Os armênios que imigraram ao Uruguai estabeleceram a “União Compatriótica de Zeytun - Montevideo”. 
uma pessoa esclarecida sobre estratégia de guerra e isso de lutas. E quando se vislumbrava uma matança, falaram: “vamos o mandar a Musa Dagh.” E conseguiram dos turcos uma autorização para ele sair, ir até a terra dele. Musa Dagh fica, aqui ta o Mediterrâneo...

(A) Eu sei sim

(H) De lá e de cá é território e de lá, de fora é mar. Ele chega lá e vê que têm cinco vilas, quatro vilas. Cada uma 800, 1000 pessoas são quatro mil armênios. E aí se reúne com os chefes da autodefesa de Musa Dagh. "Dagh” em turco é montanha e Musa vem de Moisés, “a montanha de Moisés”. Então ele diz: “olha, se nós subirmos em cima da montanha é mais fácil nos defender contra os turcos porque nós estamos em vantagem de ver de cima quando estão vindo”. E ele sendo um eclesiástico, poucos soldados, poucas armas tinha. Era armamento antigo, antiquado. E ainda fizeram uma brincadeira com o Pastor: - "Pastor, atiramos?” Ele diz: “ - cuidem de não errar nenhum cartucho". Aí conseguem um lenço gigante, faz uma cruz vermelha e escreve em inglês e em francês "aqui armênios em perigo de vida” e põem do lado pro mar. O que eles esperavam, conseguem: um barco francês se aproxima, vê, vai e chama outros barcos, pegam os quatro mil armênios. Se você vê, para baixo fica Egito e, Port Said era o porto mais próximo dos armênios. Esses quatro mil armênios depois saem de lá e vão para o Líbano e formam a vila, o bairro, a cidade de Anjar. Eram todos de Musa Dagh que foram a morar...

\section{VI) Sobre Zeitun ou até que venha o dono reclamar você ocupa}

(H) No Líbano, Anjar que fica perto da capital ou do lado, não conheço. Então outro jovem, você conhece Ascen(difícil compreender). Tinha a Vimave, Vila Maria Veículos que vendia Volkswagen e agora está uma oficina lá na Oscar Freire: "Sevan”.

(A) Tem uma "Sevan" lá perto do metrô Tiradentes, uma oficina. Bom Retiro, tem uma mecânica lá também.

(H) Eu sei que tem uma lanchonete "Sevan". Agora, ele me pediu que fizesse uma tradução da história de Aintab [atual Gaziantep, cidade turca próxima da fronteira com a Síria]. Outro rapaz que gostava de militar, entrou no exército turco e chegou a ser secretário do, não sei, general alguma coisa, mas quando ele soube que os turcos queriam invadir Aintab, ele sai pede baixa do exército e vai e conversa com os dirigentes de Aintab: "olha, eu sou fulano de tal, meu pai é de Aintab, e eu posso ajudar. [Respondem] Muito bem, você comanda a autodefesa”. Então ele conseguiu em cruzamentos importantes, em cima dos prédios guaridas com o objetivo, para ver o 
exército quando vinha e eles vinham daqui ou de cá e tinham um meio de comunicar-se para dizer “já estão subindo por aqui, já está acabando aí, está subindo daquela rua”. Não conseguiram entrar em Aintab. Uma pessoa só conseguiu organizar, você não liga que é só, é pouco, o que eu vou fazer? Mas assim como na história você sabe de pessoas que fizeram o que fizeram, todos podemos fazer muita coisa, temos que ter fé, confiar em nós mesmos, pedir que Deus nos ajude e tirar no mercado o que for para poder fazer o que você tá querendo.

(A) Mas essa defesa que o senhor acabou de falar, de Aintab, foi na Primeira Guerra?

(H) Sim, tudo naquela época dos 1915, 16, 17. Você sabe que depois de 1918 quando terminou a guerra, Primeira Guerra, muitos...meu pai conta “nós voltamos a Zeitun”. Muitos voltaram à sua cidade: “oh, já tem paz”, mas era fictício, já não estavam mais aquelas coisas deles, já tinham turcos ocupando. Você conhece ou já ouviu falar do Mekhitarian?

(A) Não.

(H) Nichan Mekhitarian é médico tem três filhos ${ }^{28}$, os três são médicos, mas te quero dizer o avó deles no ano 1972 foi à Turquia, chegou a Marash e de Marash alugou um jipe com motorista e “vamos para Zeitun”. Fica uns 30, 40 quilômetros. Subir a montanha e na chegada de Zeitun tem um caminho que se junta, tem uma árvore no meio, uma árvore grande frondosa e ele diz "me deixa aqui que daqui pra lá eu sei”. Ele saiu com 18, 20 anos de Zeytun e lá conhecia tudo, vai à casa dos pais dele, bate a porta, entra, fica olhando assim...”efendí”, os turcos, não? "Olha, meu pai era dono dessa casa aqui". "Efendí, efendí”, fazendo reverência, "teu pai era um homem muito bom, ele deixou a casa para nós quando saíram”. Tô falando do ano 1972 na Turquia, no ano dois mil e pouco o nosso Arcebispo, um americano convida ele, mais outro daqui: "vamos para Turquia, eu quero ir na casa de meus avós”, sabia tudo, endereço tudo e ele foi lá bate a porta, olha para a casa, a mulher: "Efendí?” Efendí quer dizer senhor e ele fala turco [entrevistado fala em turco] "essa casa é tua ou é minha?" [A mulher responde] "ué, explica o que quer dizer isso" [o americano diz então] "não, porque essa casa é de meu pai, meu avó” e aí conversam e quando se vão despedir, daí a mulher pergunta [entrevistado fala em turco] "me diz essa casa é tua ou é minha?" e ele diz, o armênio diz "até que venha o dono reclamar você ocupa".

\section{VII) Sobre viajar de computador até Hrapetutyun Hraparak ${ }^{29}$ e a escrita de Hran Dink}

28Há um livro escrito por Nichan Mekhitarian sobre a resistência de Zeytun.

MIKHITARIAN, Nichan. Reino armênio da Cilícia, 1080-1375: história de Zeytun 1209-1921. Edições Inteligentes, São Paulo, 2005.

29 Praça da República situada no centro de Yerevan. 
(H) Você tem ouvido falar de Hran Dink, o periodista armênio que mataram já faz seis, sete anos. Você não usa facebook e a página ian da Argentina ${ }^{30}$ ?

(A) Não, não conheço.

(H) Procura, procura. Pergunta aos rapazes como consultar, sábado minha filha abriu, eu estava sentado aqui, e ela trouxe. 24 de abril em qualquer parte do mundo.

(H) Você usa computador?

(A) Sim, sim.

(H) Você conseguiu ir à Armênia?

(A) Só no computador (risos).

(H) Computador? Conseguiu? Olha, um dia com a minha filha começamos a "baixa mais, baixa mais, baixa mais” e então chegamos a praça central, Praça da República [em Yerevan]

(A) Ah, daquelas [fotos de satélite] do Google?

(H) Que você vê de cima, então, vamos a ver o Lago Sevan, vai caminha. Você vai, você tá aqui, mas você vai. Hoje em dia...procura, você vai ver coisas lindas... Então esse Hran Dink foi um órfão que nasceu na Turquia e o pai faleceu e a mãe leva a um orfanato da Igreja Evangélica [Armênia]. Ele estuda lá, chega a ser maestro (professor) para ensinar as crianças menores e aí entra no periodismo, mas no periodismo ele não escrevia abertamente "o turco matou o armênio", mas dava a entender nos artigos que ele escrevia, ele sabia de uma maneira expressar que os turcos, a polícia, o governo, ficaram preocupados de que "este vai influenciar o pensamento do povo" e pediram a algum louco que "vai e pega dois tiros". Agora, um turco matou um turco, a mulher falou "você nasceu nessa terra,você estudou nessa terra, você amava essa terra e não deixaram que você viva”, a mulher. Eu conheci ele no ano 1996 fomos a Istanbul e lá precisávamos conhecer esse homem, quem era, você via ele não dava nada, quieto, tranquilo, de pouco falar, pouco falar, mas o cara tinha capacidade para escrever.

\section{VIII) Sobre ser Garmir, negacionismo, reconhecimento do Genocídio em Montevidéu e patriotismo na escola.}

30https://www.facebook.com/ianamigosdearmenia/ e o site http://www.ian.am/ 
(A) Hoje continuam essas coisas, na Turquia o negacionismo é muito forte, né?

(H) É que, assim como hoje se fala, você sabe que em janeiro os judeus pediram uma reunião com os armênios e aqui um amigo meu, uma pessoa importante na colônia: "não, nós não falamos com os judeus”. A meu entender perdemos uma chance importante para cativar, nós não vamos mudar a ideia, o conceito do judeu que eles querem que o Holocausto seja único, que não haja outro similar, né? Porque aí prejudica, mas se você...na Argentina conseguiram ter um diálogo com o judeu para que o judeu procure, porque o judeu não é amigo do turco, mas nós temos que ter a capacidade que quando se fala com os turcos, quando faz dois anos, três anos, se falou aqui de se fazer uma que armênios e turcos se reuniram em Suíça, Genebra para chegar a fazer um acordo. Foi a Hillary, [Bill] Clinton foi também. Eu tenho um sobrinho que naquele tempo morava aqui em casa e um dia me mostra "olha tio, agora está tendo lugar uma reunião em Genebra entre os turcos, armênios e o americano". Na hora que tava acontecendo lá tava no computador e ele me mostra, aí pararam porque o armênio queria incluir a palavra genocídio e eles não aceitaram. Agora, por que não somos inteligentes e assim como esse judeu austríaco Raphael Lemkin que conseguiu, ele chegou a ser secretário da Embaixada Americana na ONU com sua capacidade, sua lábia para poder influenciar. Montevidéu, Uruguai foi o primeiro país que reconheceu o Genocído [Armênio] em 1965.

(A) O senhor tava envolvido nisso?

(H) Não, isso te conto eu porque eu vivi. Se você procura vai ver que em Montevidéu se formalizou a Mesa Coordenadora de Organizações Juvenis Armênias, tinha seis ou cinco entidades juvenis fortes na Armênia no ano 1962, 63 e chegaram ao ponto de que tinha concorrências às vezes desleais. Quando a UJA fazia uma festa, a Marash, a juventude fazia uma semana antes e uma semana depois e atrapalhava. Então eu era presidente da Liga e chamei o presidente da UJA que era muy amigo. Digo: "tô pensando assim, se fazemos uma mesa que coordena as atividades, cada mês uma entidade e secretaria. Então você é da UJA, vai fazer uma festa, liga. 'O José, em agosto que festa temos, que domingo, que sábado tá ocupado? Que festa tem?' Tal, tal e tal ou não tem. 'Tá, então marca para o dia para a minha entidade'”. Então chegamos a um convívio pacífico e bem, não tínhamos briga. Briga era no futebol (risos)... Agora, que aconteceu, chegou 1965 era cinquentenário do Genocídio e nós conseguimos fazer uma comemoração...faz de conta que fosse a Paulista entre sete, oito quadras. Tem a Praça Independência e aqui em cima a Praça Liberdade, caminhada mil pessoas, mais de mil pessoas conseguimos parar de tarde 14:00, caminhar e chegar a Praça Libertad e lá tinha um prédio Ateneu de Montevidéu. Ateneu era o local livre, para livre 
expressão, você pedia, ocupava e nós conseguimos ocupar isso, chamamos um historiador da Argentina, ele veio fez a palestra sobre o genocídio e a história que escreveram ficou tão boa impressão essa passeata pacífica, com cartazes que em novembro se conseguiu que o governo reconhecesse primeiramente o dia de recordação dos mortos armênios e depois isso se transformou em reconhecimento de genocídio. Agora, quem... assim, de graça não vem, aí depois que fez aquilo nós tínhamos na diretoria, na mesa um químico que tinha uma amizade com um político. “Ah, eu conheço essa família”, senador uruguaio sou muy amigo da mulher...28, 29, 30 de novembro, dia primeiro de dezembro começava as férias do Legislativo. Então se em 30 de novembro não conseguia assinatura de reconhecimento da data 24 de abril já ficava para o ano que vem, até meia noite na porta da secretaria um rapaz ficou lá esperando até que pouco antes da meia noite ele traz o papel assinado... eram cinco, seis pessoas e conseguimos um reconhecimento, algo que hoje (risos)...você para fazer... esse Azevedo, o embaixador que ganhou cargo na Organização Mundial de Comércio (OMC) , ele não tem apoio nem de EUA nem de Europa, mas conseguiu votos suficientes entre África e países em desenvolvimento. Onde estava o embaixador armênio em Brasília para dizer: "olha, meu país apoia você" ? Assim como hoje, os assessores desse embaixador estão indo visitar nos países que votaram nele de África para ver que estão precisando. Oh, (risos) penso que (pausa) isso é um cabeça. Não que o turco matou, não o turco não matou, o governo turco que matou. Se armênio, que cada vez são menos que podem contar a história do que eles passaram. "Olha fulano viveu porque um turco vizinho pegou e guardou na casa dele”, você sabe que, cê falou, não sei se ficou sabendo turcos que vão para a Alemanha a trabalhar de faxineiro, a Alemanha precisa faxineiro e os turcos foram lá e têm muitos turcos que eram armênios, que ficaram vivos porque o pai não era tão patriota armênio, trocou de sobrenome e ficou turco. Como é teu sobrenome?

(A) Attarian.

(H) Attarian, Attarian?

(A) Isso.

(H) Não, não, conheço.

(A) Na Argentina tem bastante dizem...

(H) Em Montevidéu tem também Attarian. Então o cara botava Ataroglü, né? Assim, turquificado.

(A) Attarian são de Urfa. 
(H) Não tenho conhecimento da história de Urfa. Os armênios outro dia, quando digo outro dia ano passado, um periodista, uma periodista foi a Armênia para pesquisar os armênios agora que estão na Alemanha estão voltando a trocar de sobrenome e usar o sobrenome armênio. Claro não tem perigo ${ }^{31}$. Tem duas igrejas apostólicas na Alemanha em Berlim, aqui vão os que vieram da Turquia e aqui vão os que vieram da Armênia. Então os que vieram da Turquia dissem: "nós não vamos querer juntar com vocês porque vocês um dia vão para a Armênia e nós nunca vamos voltar a Turquia... e o perigo do armênio, do jovem armênio que vive na Alemanha que é? Não casar com alemã, casar com turca porque sabe o idioma, não? (risos) E as turcas são lindas! (risos) Olha, você tem que ir um dia, não se deixe levar "turco”, não, não é turco é Turquia. Você, quando a Armênia era soviética, eu era comunista quando visitava a Armênia? Não. Meu pai me ensinou a amar a Armênia comunista em Montevidéu me chamam de Garmir, de comunista, de vermelho. “Vocês são comunistas”, [retrucando] “por que?” [outro responde] "Você vai na escola [armênia], quem dirigem eles?”. E o que eu aprendi de patriotismo foi nessa escola.

\section{IX) Como você sabe? E “isso aqui parece a ONU”.}

(A) O senhor estudou em escola armênia lá no Uruguai?

(H) Sete anos. De manhã na escola pública e de tarde a escola armênia, era dez quadras, mas te quero dizer, se você conversa com o pessoal da UJA “NO Turquia”. Não Turquia, não. Por que não vamos a procurar, entrar na Turquia e começar a arregimentar turcos que queiram conhecer ou que o governo de turco naquele ano que os Jovens Turcos assumiram o poder. Você sabe que em Adana depois que a matança...você vai dizer, quem contou isso? Como você sabe? Nessa época nesse mês teve o encontro de pastores evangélicos em Adana, trinta e tantos pastores e um chegou tarde.

(A) É, isso tem em uma reportagem do New York Times, né? Que é um relato desse pastor, não é? Na época...

(H) Ele chega lá e conta "eu sentei em frente da Igreja Armênia, queimada, a porta aberta escancarada e eu via a marca dos dedos das mulheres das pessoas desesperados queriam subir" $e$ ele falava muito bem turco, muito bem turco, então os armênios de Istanbul decidiram que ele fosse falar com a milícia, o governo turco que fez a matança dos armênios de Adana, conseguiu ir falar 31 Em 2015, simbólico ano do centenário do Genocídio Armênio, ocorreram tensões nas ruas de Berlim entre armênios e turcos. 
“amigos, nós somos amigos dos turcos que moravam lá em Adana, eramos vizinhos nos dávamos muito bem, nós pagamos nossos impostos, não somos contra o governo turco" e conseguiu uma... como se diz... uma recompensa do governo turco de 300 mil libras ouro para os armênios de Istanbul. Lógico só valeu por três meses, quer dizer que tinha pessoas que eram capacitadas de ir lá e discutir com ele, lógico que podiam alguém pegar um tiro e liquidá-lo. Você sabe que 1999 setembro teve o primeiro encontro armênio da diáspora em Yerevan.

(A) 1999?

(H) 1999, eu fui, eu fui, eram dois, três mil armênios do mundo, você via um ginásio. Eu quando entrei “puxa isso aqui parece a ONU”, bem organizado, com auriculares, você entrava te davam um aparelho para você ouvir russo, inglês, armênio e espanhol. Até esse ponto tinha chegado na Armênia para as pessoas que vão lá e... quantos armênios, depois que falou o presidente, o ministro de guerras, dois meses depois um louco invade o recinto do parlamento e mata cinco, seis armênios... o presidente da câmara dos deputados, o ministro de guerra, por que? Porque dizem que eram corruptos. 


\section{7) Relatos platinos}

\section{Nota introdutória a estes relatos de viagem}

E aonde que está a vida? Aonde que está a experiência? Já te entregam tudo pronto, sempre em nome da ciência, sempre em troca da vivência

“Tá na hora” por Raul Seixas

Em abril de 2016, dias depois do exame de qualificação, viajei em direção ao Uruguai e a capital argentina, Buenos Aires. A viagem foi feita grande parte sobre bicicletas e a ideia era fazer um trabalho de campo para procurar pessoas e informações sobre comunidade armênia no Uruguai e participar dos eventos que anualmente rememoram o Genocídio Armênio em Buenos Aires, na data mundial de 24 de abril.

Saindo da cidade fronteiriça de Chuy - RS no dia 09, chegamos à Montevideo depois de oito dias pedalando. Mas antes, por acaso, conhecemos Patrícia em Piriápolis, que nos deu o contato de sua amiga da capital e dos tempos de colégio, a descente de armênios de alcunha Kiki. Apesar de ter sido o único contato uruguaio em relação com o tema de estudo, nos trouxe reflexões importantes que repercutiram muito dali em diante e na segunda parte do texto isso fica evidente. Ainda antes de chegar na capital uruguaia, em Parque del Plata, recebi a notícia aprovando minha participação como voluntário na Armênia já para o segundo semestre de 2016, experiência que tentamos elaborar na segunda parte do texto.

Em Buenos Aires o contato armênio nos foi arranjado pelo colega de estudos Heitor Loureiro. Sua amiga Maria Florencía foi uma pessoa incrível que nos apresentou amplamente o contexto da importante comunidade armênia de Buenos Aires.

Estes relatos tratam de alguns momentos dessa viagem platina que também guarda lembranças sobre Porto Alegre dias antes de cairmos na estrada.

Punta del Diablo, 09 de Abril de 2016.

Foi necessário consultar um vendedor no Aeroporto Salgado Filho, que pesquisou através do Google maps de seu smartphone o caminho do Aeroporto até a casa do casal que gentilmente nos 
hospedou, Helô e Jack, amigos de uma querida amiga gaúcha residente em São Paulo. O caminho passava, especialmente em seu começo, por avenidas de ex-ocupação industrial. Avenida dos Estados, A. J. Renner, Av. Farrapos, Av. Goethe. Nalgumas dessas avenidas havia uma acampamento da moral verde-amarela com bandeiras onde se lia “In Moro we trust”. Pedala, pedala até, por meio de outras ruas menores, chegarmos à Rua Casimiro de Abreu. Os dois foram pessoas amáveis, logo no primeiro dia Helô fez um almoço muy rico com arroz, frango com molho e um creme à base de queijos; depois demos uma volta por Porto Alegre, pelo gasômetro, Muro da Vergonha, Lago Guaíba, Estádio Beira-Rio e a Zona Sul que tem algo de "rurbano", inclusive comentamos naquela hora sobre o termo como algo antigo, que pouco se utiliza nos atuais vocabulários das ciências sociais, antropologia, geografia, etc. Lembrei que, me parece que para Amélia no texto sobre a "urbanização crítica”, o "rurbano" é crise e crise que se expressa na necessidade de subsistência frente a uma cidade toda mediada por dinheiro e nesse ponto há de se ponderar, como foi ressaltado na conversa da banca de qualificação, que essa crise refere-se ao “rurbano” da conjuntura da 2004 e pensar Porto Alegre atualmente é interessante, mas difere das condições do “rurbano” da formação de Presidente Altino nos primeiras décadas do século XX.

Heloísa estuda a condição dos moradores em situação de rua na cidade de Porto Alegre e nos falou sobre os diferentes posicionamentos políticos entre as personificações envolvidas no debate que ocorreu na Universidade recentemente. Acadêmicos, classe trabalhadora representada pelos sindicatos e os próprias pessoas em situação de rua. Lá, como em São Paulo, o crack rola direto e é entendido como problema de saúde pública. Os números de cada envolvido na questão da gestão variam bastante, sejam eles oriundos do Estado, das OS, ONG's ou pesquisadores, mas as cifras ficam entre 1.800 a 4.000 pessoas em uma cidade de 1 milhão e meio de habitantes. Claro que é problema contar uma cifra alta para a administração pública, mas nota-se que o contar é muito impreciso (e quão tenebroso é lidar com gente como uma questão de metodologia estatística) por conta da mobilidade dessa parcela da população. Seriam os supérfluos os mais móveis na crise do trabalho? $?^{32}$

32 Max Sorre ao final de seu texto de 1955 sobre "migrações e mobilidade do ecúmeno”, texto já tematizado em uma nota páginas atrás acerca do debate sobre "habitat”, dedica um item aos "casos limites da mobilidade geográfica máxima”. O autor vai tipificando pejorativamente das mais variadas todos aqueles que representam os "incapazes de se fixar”, de maneira a certificar maior valor moral ao "sedendário”. Se o primeiro é "vagabundo”, "sem eira nem beira” e "tem horror ao trabalho", o segundo "desconfia desse homens da estrada, sem noção exata do meu e do teu, e se precavém contra seus pequenos furtos, sempre pronto a suspeitar de ações piores por parte deles” (Sorre, 1984: 131). Mas a caricatura dos errantes constantes vai adiante, demonstra que há um pressuposto do trabalho como mediação social abstrata generalizada que coloca a possibilidade dessa mobilidade, pensa também nos "homens de fronteira”. Mas é tipificando os ciganos de vagabundos desde muito antes da moderna relação capitalista e sem esquecer da perseguição nazista sofrida por esse grupo, que Maximilien Sorre os entende como “a imagem viva da mobilidade pura”. Os ciganos representam ao autor o “caso-limite de um instinto migratório coletivo”(idem: 134). 
Visitamos a Galeria Chaves, que aparece na trajetória de Manuel Gureguian narrada por nosso entrevistado, cem anos mais tarde e não havia mascates sentados em banquetas. Em Porto Alegre há bastante comércio ambulante e pessoas pedindo dinheiro. Pude notar enquanto almoçava no Mercado Público, mas também em todo o Centro e Cidade Baixa na noite anterior. De bicicleta conseguimos passar nesses bairros como também na Bela Vista, cercanias do Lago Guaíba e outras partes; o costume de pedalar em São Paulo faz as outras capitais parecerem pequenas, com bairros mais colados.

Buenos Aires, 24 de abril de 2016

Esse é o dia com maiores marchas e manifestações para os armênios e também para os armênios da Diáspora. Desde o Uruguai, na conversa com Kiki, o tema Diáspora é bem frequente e organizado. Cristina Nerguizian Demirdjian, a Kiki, contou que os bairros La Teja y Cierro, situados na periferia (será que naquele tempo foram subúrbios?) de Montevidéu, receberam imigrantes de todos os lados nas primeiras décadas do século passado e indicou o livro de Alberto Douredjian e Daniel Karamanoukian intitulado "La inmigración armênia em el Uruguay” que foi publicado em 1993. Disse também que os armênios que chegaram durante o entre guerras encontraram um país despovoado e cheio de imigrantes recém-chegados, um cenário muito diferente da imigração contemporânea que varre para lá e para cá a superpopulação transnacional do capital. São os supérfluos, os excedentes das guerras pela edificação de outras tantos monumentos à cultura e à barbárie, para lembrar Walter Benjamin, que viveu a ascensão do nazifascismo no entre guerras até o evento de sua morte em Portbou, Espanha, aos vinte e seis dias do nono mês de 1940.

A imigração que veio fazer a periferia sul-americana do capital começou com pouco e, nesse ponto, a personificação do imigrante armênio “com uma mão na frente e outra atrás” ganha ares gaúchos, uruguaios, argentinos e pode-se dizer da metrópole porteña (Montevidéu y Buenos Aires pensadas num mesmo processo) na memória da segunda e terceira geração dos sobreviventes do Genocídio.

Fato interessante de se notar, por outro lado, é a miséria dos assim chamados Direitos Humanos, esse clamor pela democracia e o tal Estado de direito pleno, aquele que não sofre constantes saques realizados pelo grande capital sobre a classe trabalhadora. Para muitos argentinos com quem conversei, Macri em suas políticas alinhadas com o neoliberalismo deste século representa esse saque. Humanidade, otra vez más, cola em quem é sujeito do valor, o eleitor registrado que paga imposto de renda... 
Os sírios que vem sendo varridos desde 2011 para toda parte, nos disse Kiki, não se adaptaram muito bem ainda ao Uruguai e o Uruguai, por sua vez, busca adaptar-se aos sírios por meio de sua política de incentivo a imigração desses refugiados que de uns tempos pra cá fogem também do Estado Islâmico (ISIS). Cem anos atrás, quando a juridificação era frouxa, quando ainda não se usava a palavra genocídio, mas que, ainda assim, a memória contada pelos descendentes daqueles imigrantes e que vem se perpetuando insiste em dizer que se ubiquar na e fazer a América, naquele tempo tão atrasada nos processos de acumulação do capital era más tranquilo e possível do que é hoje. Hoje se tornar sujeito do valor nas metrópoles periféricas é difícil até em territórios em que o Estado se esforça em fazer “políticas humanitárias”, como foi o Uruguai de Pepe Mujica.

Buenos Aires, 23 de abril de 2016

Otra vez más me atrasei, mas ao fim consegui chegar bem no momento do anúncio ao microfone feito pelo Presidente da Unión Cultural Armenia, Adrian Lomlomdjian, dizendo que o ato estava se iniciando.

Ato conjunto com a lucha de otros pueblos, quien cres que los derechos humanos hace de otra fuerma. O evento foi organizado pela União Cultural Armênia, uma organização de origem comunista que existe há mais de 80 anos. Fui ao evento convidado por Maria Florencía Di Matteo Demirdjian, amiga de Heitor Loureiro e que havia me apresentado na noite anterior todas as instituições da coletividade armênia de Buenos Aires situadas no bairro de Palermo - Calle Armenia em especial. Maria Florencía contou-me que no ano de 2015, quando os atos foram unificados por conta do centenário do ano mais sangrento dentre os tantos anos de massacres da modernização desesperada e em guerra da decadente Porta. Tal processo passa pela expropriação que reorganizou territórios e repovou utilizando sua superpopulação turquificada ${ }^{33}$. Em 2016 as manifestações foram divididas entre a comunidade armênia da cidade e, pelo pouco que foi possível captar, os "lados” eram compostos por, de um lado, a comunidade relativa ao Clube, Igreja e Teatro, mais conservadora, sediada no rico bairro de Palermo e que promoveu uma passeata no domingo, 24 de abril. De outro lado, a União Cultural Armênia que promoveu o evento na Praça Armênia no sábado, 23 de abril.

33 Na próxima parte tentamos apresentar uma problematização mais cuidadosa sobre a expropriação, deportação e repovoamento na formação do Estado nacional turco durante a guerra de 1914, na qual o Genocídio Armênio se insere. O conceito de superpopulação relativa desenvolvido por Marx ao falar da "Lei geral da acumulação capitalista” anda junto do processo de expropriação, que o autor expõe no capítulo seguinte “Assim chamada acumulação primitiva”. No caso particular estudado tentamos apontar para a ocorrência de uma centralização e acumulação de capitais que se desdobrou em massacres e homogenização populacional em larga escala, a assim chamada turquificação. 


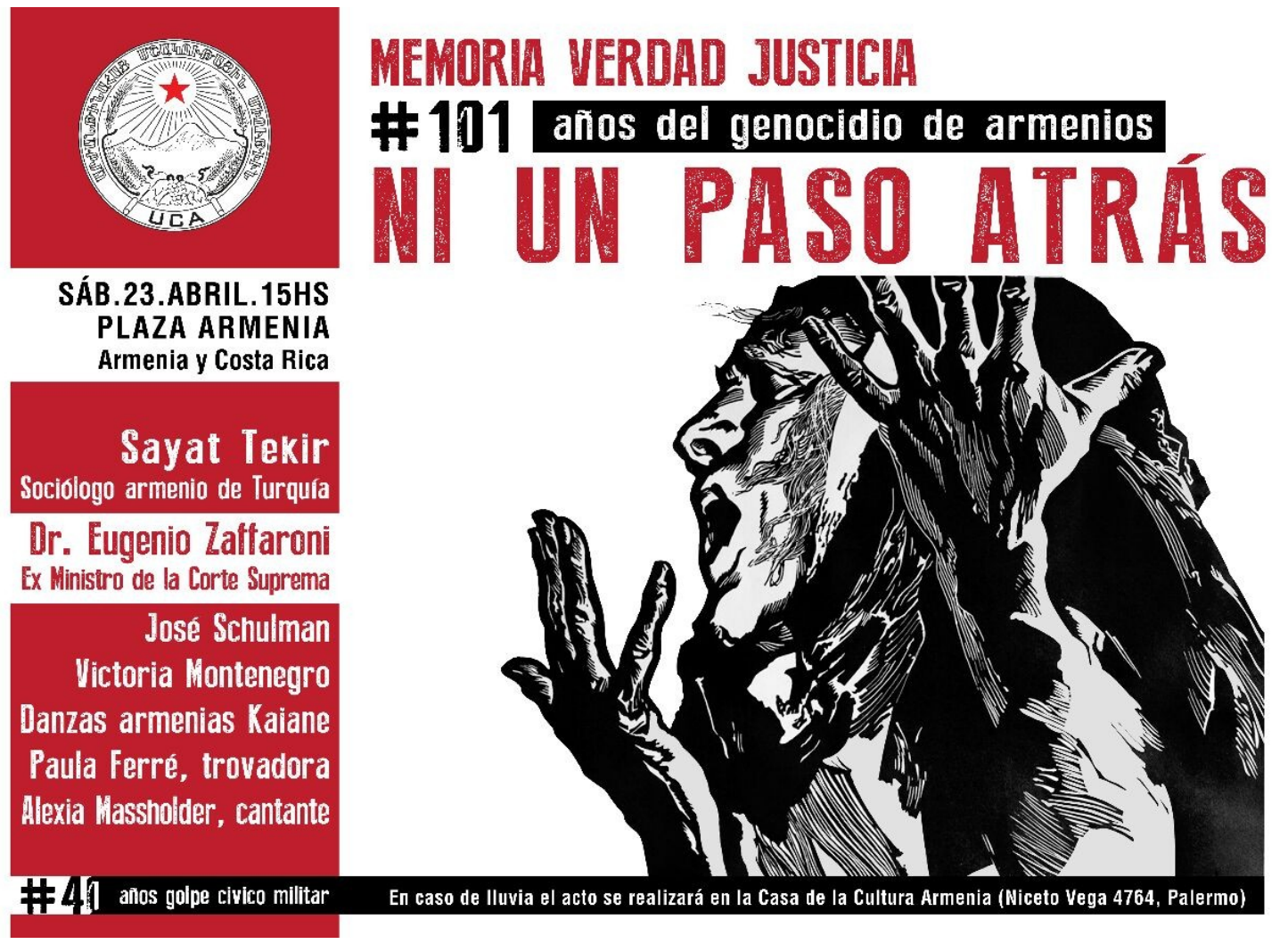

Figura 1 - Cartaz do evento organizado pela Unión Cultural Armenia de Buenos Aires (2016)

Estavam presentes o embaixador russo na Argentina e outros tantos notáveis. Durante todo o ato foi sendo pintado um grande quadro representando o Monte Ararat em um fim de tarde púrpura, esse quadro ficava atrás da mesa onde ocorriam falas, intervenções, informes, apresentações musicais e danças armênias do grupo Kaiane. O primeiro convidado a falar foi Jose Ernesto Schulman, Secretario Nacional de la Liga Argentina por los Derechos del Hombre. Foi uma fala bem ao modo do partidão, enfática, combativa ao governo Macri, que segundo Schulman "sonha com um novo genocídio”, e permeada de alardes sobre a conjuntura internacional imperialista e o genocídio como prática do Estado contemporâneo. Iniciou dizendo que há muitas maneiras de fazer memória e que o Legislativo argentino reconheceu o genocídio armênio em 2009, mas que um juiz, atuante durante os anos da ditadura (1976-83), abafou o caso dizendo que não houve genocídio contra os armênios. O secretário indagava: por quê e para quê? Seguindo na sua resposta "para poder por em marcha o Estado capitalista turco” e para promover a acumulação primitiva baseada na limpeza étnica. Alertou para o fato de a Turquia ser membro da Otan, representando uma “das bases mais importantes da direita” e recordou também que a promessa de Estado laico feita pelos Jovens Turcos deu em ossos no deserto. "El imperialismo és un problema de hoy” foi a provocação escolhida para encerrar a intervenção ao associar a ascensão do governo do Macri, a crise na 
Venezuela, o golpe no Brasil com políticas intervencionistas de Obama, o que ocorre, nos sugeria Schulman, é uma “operação contra-insurgente continental” que implicaria em uma espécie de continuação do Plano Condor. Além desta provocação, outras colocações interessantes foram postas: a memória como um problema ético, em outras palavras, o que fazer com a "verdade”? “Pretendem borrar la historia y nosotros resaltar la memória”.

Ao final, relembrou o lema da Revolução Mexicana que, como o genocídio perpetrado pelo Império Otomano sobre os armênios, já é mais que centenário: “Todo para todos”.

Sayat Tekir, armênio que vive na Turquia foi o segundo convidado a falar. Só sua posição no debate já é motivo de interesse: como é ser armênio na Turquia? Afirmou que estava acontecendo um “novo despertar”, ou seja, mais gente na Turquia tem se aproximado com os temas relativos a 1915. Dizia que “não nos aniquilaram e não vão poder” e que Erdogan quer um outro genocídio agora sobre os curdos. “Hoje um fantasma ronda a Turquia, o fantasma dos mártires de 1915”, disse Tekir ao fazer um desvio de Marx e Engels no Manifesto Comunista de 1848.

A Argentina, para ele, foi um exemplo de como tratar crimes públicos, ao se referir a todo o trabalho de pesquisa, documentação, julgamento, reparação e memória sobre os crimes e violência perpetrados pelo Estado argentino durante a ditadura.

Optamos por transcrever a fala do jurista Eugenio Zaffaroni no evento e em seguida comentar alguns pontos. A exposição completa da fala é uma escolha para que não se perca a interessante análise feita pelo jurista argentino, uma vez que os posteriores comentários não desdobram uma fala tão ampla e que articula habilmente temas do Direito internacional, memória e identidade, acumulação primitiva, colonização, crises políticas atuais e também a subjetividade contemporânea. É também um registro para se pensar quais ideias estão circulando nos debates sobre Genocídio Armênio.

Transcrição comentada da fala de Eugenio Zaffaroni em Buenos Aires, ato da Unión Cultural Arménia, dia 23 de abril de 2016.

[traduzido do áudio em espanhol do arquivo pessoal do tradutor]

Zaffaroni: Companheiras, companheiros, antes de tudo quero agradecer não só pelo convite, mas agradecer aos armênios, aos descendentes armênios e toda comunidade armênia. Agradecer pelo que fazem, agradecer-lhes pela memória, a memória de um genocídio, a memória de um crime 
tremendo, dos mais inqualificáveis dos crimes. Por fazer a memória porque é um crime contra a humanidade. Recordar de um genocídio é sempre é fazer algo pela humanidade, recordar a todos o potencial de malignidade que pode ter uma humanidade que se perdeu. Acordar, voltar a ter a corda, a etimologia parece dizer coisas. Em português acordar significa despertar. Todas as lembranças do passado têm que estar presentes e um genocídio aconteceu e pronto. Sempre que tem esta memória vai estar presente e sempre que esteja em nossa memória nos faz dar conta que isso pode repetir-se.

E quando despertamos a este presente, cuidado que se está repetindo, se está repetindo silenciosamente, se está repetindo de uma forma em que os meios massivos de comunicação monopolizados ao serviço das corporações transnacionais estão ocultando. Esta se repetindo nesta região, se está repetindo na América Latina. Lhes agradeço pela conservação da identidade, dos vínculos culturais. Somos os latino americanos, há quem diga que não somos nada porque somos uma mescla de tudo, tome cuidado, cuidado, olhemos a história, os originários submetidos, a colonização feita por marginais da Espanha, cristianizados a bordoadas (garrotazos)... um pouco antes o que chamaram desta maneira "A Reconquista”, não vejo nada de reconquista eu vejo recolonização e logo trouxeram os africanos escravizados e logo quando se terminou o tráfico escravista, escravizaram uns quantos orientais, os latinos, os do pacífico. Logo vieram todas as coisas que passaram pela Europa e vieram nossos avós, seus bisavós, tataravós. Deslocados (desplazados), deslocados da Europa por estarem atrasados em um processo de acumulação primitiva (original) de capital. Somos o resultado de todas as margens do poder planetário. Somos a síntese de todas as partes, viemos ao liquidificador desse resto planetário. Os grandes glorificadores, um Hegel que diz? O instinto foi avançando e deixando no caminho os orientais porque eram teocráticos, os arábes porque eram sensuais, aos judeus porque estavam ao serviço do absoluto e que os negros, vamos, eram mais próximos ao plano animal, nós não tínhamos história, recém eles nos tocaram e vão a ter história. Esse é o espírito ou isso é um fantasma? É algo, algo que vai destruindo à medida que avança em seu caminho e tudo que foi destruindo e marginalizando de alguma maneira veio dar na América Latina, onde mais ou menos nos comunicamos em idiomas parecidos e não no planeta outra região tão ampla onde tantos milhões de habitantes possamos inter-atuar, representando o que foi o resultado do negativo deste processo de dominação planetária que temos hoje com o nome de globalização, mas não é um capítulo a mais que o colonialismo.

Lhes agradeço a identidade e a recordação permanente. Não me chama a atenção, não me chama a atenção o encobrimento terrível que sofreu o genocídio armênio, porque não creiam vocês que a conferência sobre genocídio e a Declaração de Direitos Humanos e tudo isso saiu porque 
alguém se sentou a pensar-lo a fazer progressar a razão. Não lhes importou o que estava fazendo Leopoldo II da Bélgica no Congo, não lhes importou o genocídio armênio, não, não lhes importou o que fizeram os alemães com os hereros ${ }^{34}$, não, lhes importou quando a vítima foram eles que tinham a mesma cadência de melanina que os que dominavam. Recém, então, recém tiveram medo, lamentavelmente essas coisas avançam, por que? É um documento importante, sim, sem dúvida, etc. Não foi um simples impulso da razão, mas sim uma reação frente ao temor, frente a Deus [difícil compreensão de áudio nessa parte]...se não, não haveriam saído, se abrem fossam, se abrem tumbas e se abrem de todos os lados, se abriram aqui, se abrem em Colômbia, se abrem no México, mais tardiamente se abrem na Espanha, com resistência, porém se abre. Os mortos às vezes falam, têm que falar por mais que muitos queiram emudecer-los. Eu agradeço a vocês que façam falar seus mortos, que estejam presentes. Realmente creio que não importa o que pode acontecer em algum momento, o encobrimento terrível do genocídio armênio não há como ser mais hipócrita. As potências vencedoras da Primeira Guerra Mundial o reconhecem, mas logo adiante consertam: "o resto desapareceu” porque o que lhes interessou antes os lucros setoriais, quem recordar escreva. Que vamos fazer? Os armênios não têm poder, então o encobrimos e não olhamos. O que fizeram foi apagar a memória e graças a vocês a memória não lhes é apagada e não poderão apagar, como não poderão apagar a memória de nenhum genocídio e essa memória que dizia nesse momento, essa corda que se prende com o passado nos leva a este presente. Um presente que não é bom, um presente onde vemos de novo sobre nossa visão algo que já passou outras vezes, já passou fazem 60 anos, já passou com o suicídio de Vargas, passou na Guatemala, o bombardeio de nossa cidade, já passou fazem 20 anos depois com o Plano Condor e agora volta a acontecer (passar) com outra tática, agora nos entram, mas pelo monopólio midiático e pelos efeitos institucionais de nossos poderes judiciais, pelo menos no Brasil e na Argentina.

Realmente não tenho dúvidas, não tenho absolutamente nenhuma dúvida de que os povos se movem, nunca ficam quietos, a sociedade é dinâmica, mas olhemos para a nossa América e tentemos, acordemos, como diriam os brasileiros, despertemos. Despertemos e veremos não há só genocídios passados, estamos vivendo hoje um genocídio, incluso nesta região, por favor demos nos conta e não se trata só da parte violenta, não, é certo que temos índices mais altos de

34 Hereró ou herero é um povo banto que, junto ao povo namaqua foi brutalmente massacrado pelo Império Alemão no Sudoesta Africano Alemão, protetorado alemão desde 1884 onde hoje localiza-se a Namíbia. O evento é considerado para muitos como o primeiro genocídio do século XX, ocorrido entre 1904-07. Estima-se que mais da metade dos dois povos pereceram nos deserto Omahake, depois de terem sido derrotados pelas tropas do general Lothar von Trotha em agosto de 1904. Além de inanição no deserto, os alemães envenenaram poços utilizados pelos presos no deserto. 100 anos depois, em 2004, a então ministra do desenvolvimento pediu desculpas: Nós, alemães, aceitamos a nossa responsabilidade moral e histórica e a culpa pelos atos realizados pelos alemãe na época”. Nesse evento surge a imagem máxima do terror que foi colonialismo orientado da ideologia do darwinismo social, a medição craniana dos presos do protetorado como científica prova superioridade branca. 
homicídios do mundo, os 25 países que passam, América Latina e Caribe, só nos salvamos Uruguay, nós (argentinos) e Chile, o resto todo. E não é isso só, temos violência institucional, temos mentalidade policial, a amainaram em nosso país (Argentina), claro, mas nos anos 1980 quando renunciaram os fatos sistemáticos, não, eles se produzem. Há mortos, mas não é sistemático, mas olhem para o Brasil altíssimas cifras de violência institucioanal de qualidade policial e com um claro corte, perfil racista. Olhemos ao pobre México, como dizia o velho ditador Porfírio Diaz: “Os deixei para Deus e estão sempre com os Estados Unidos”. 120.000 mortos de violência, 130.000, 140.000 mais 20.000 desaparecidos. Olhemos para a centro América, olhemos Honduras. Honduras têm uma cidade que tem o índice mais alto de homicídio de todo o mundo e não só temos isso, somos campeões de coeficiente de Gini, o coeficiente que mede a desigualdade social. Temos o coeficiente de Gini mais alto que o da África, África é mais pobre, mas tem menos desigualdade, nós temos mais desigualdade e todo isso se marca na violação ao direito humano ao desenvolvimento, tenhamos-o claro que não somos essa violência manifesta, mas uma que gera muito mais mortos por deslocamento forçado de população, por deslocamento por razões econômicas, por concentração urbana e capacidade de emprego, por inadequação das vias de transportes a os veículos que temos, por falhas à atenção sanitária, por inseguridade laboral, é algo... se somássemos todos esses mortos de subdesenvolvimento nos aterraríamos com o número, mas não se trata só de uma questão de números, se trata também da uma questão qualitativa. Nunca um genocídio é uma questão contável, vocês o sabem bem. Alguma vez recebi uma carta de um embaixador turco que disse: "Não foram 1 milhão e meio" que parará que não sei quantos mil. Podem suspeitar que o contestei. Na verdade que estamos vivendo um genocídio por gotejamento, genocídio por gotejamento que as vezes se converte em genocídio em jorradas. De repente nós vemos algumas coisa, sim nos mostram algo que não podem ocultar, foram os 43 garotos de Ayotzinapa ${ }^{35}$ sim, mas isso realmente era algo que não podiam ocultar, o resto nos ocultam. Por isso acordemos, despertemos. Eu lhes agradeço, volto a agradecer, volto a agradecer a recordação, a memória, a identidade porque tudo isso nos ajuda a todos. Os genocídios são uma questão de toda a humanidade, não é uma questão de tal e qual grupo, sim há o grupo vitimizado, não há que

35 Em 26 e 27 de setembro de 2014 dois ataques ocorreram na cidade de Iguala, México, contra estudantes da Escola Rural de Ayotzinapa, pequena cidade do estado de Guerrero, resultaram em seis mortos - um dos quais brutalmente torturado: lhe arrancaram os olhos e a pele da face ainda em vida -, cerca de 20 feridos e 43 desaparecidos. Os atos de violência foram perpetrados pela polícia municipal (e segundo a midia o grupo paramilitar Guerreros Unidos) contra os estudantes que voltavam de um boteo, atividade de arrecadação de fundos, com o objetivo de financiar seu traslado à Cidade do México para a manifestação de 2 de outubro, em memória ao massacre de Tlatelolco. Essa ação parece ser de caráter estritamente político, como prevenção à organização de movimentos insurgentes contra a gestão neoliberal mexicana, mais uma crua manifestação do terrorismo de Estado, que segue sem maiores explicações até os dias atuais. Em 2016 alguns juízes federais mexicanos chegaram a afirmar que a hipótese de desaparecimento já é desacreditada e o fim mais provável dos 43 estudantes parece ter sido a execução sumária. 
discutir a vitimização, mas o genocídio é uma questão de humanidade e vivemos um mundo neste século particularmente complicado, um mundo que não reivindica em alguma medida com a humanidade pesem as injustiças e por que? Porque se pensamos que vivemos em um mundo em que a quarta parte da população do planeta gasta o que não necessita, que consome o que não necessita para viver e três quartas partes que carecem do que necessitam para viver com dignidade e uma parte, que esses nem sequer o necessário para sobreviver. Realmente temos que chegar à conclusão que nesse enorme poço de injustiça a violência é pouca. E então com os loucos assassinos? Realmente, só reivindica com a humanidade e me fazem pensar que tenho toda a certeza que nossos povos se movem, se movem todos os povos do mundo e a solução nós temos que buscar pela via do direito, pela via pela qual e em razão de nossos defeitos não são penetráveis, sim. Hoje não dão golpes de Estado tradicionais, hoje não rompem as instituições, bombardeiam cidades (isso segue dando dinheiro sim!), não. Hoje nos entram pelos dois efeitos institucionais, não logramos proibir o monopólio midiático e não logramos reconstruir uma estrutura racional de nosso poderes judiciais.

Creio que é chegada a hora de repensar aquela fórmula de Marx de que direito é o instrumento da classe hegemônica, sim, em seu tempo tinha a razão, mas creio que temos que eles querem que o direito não seja nada mais que o instrumento das classes hegemônicas que hoje são as corporações transnacionais. Temos que pelejar para converter o direito em um direito a serviço dos humildes, é difícil, já sei, é difícil. É conjuntural do direito, por isso devemos tentar-lo e creio que vamos a lograr, estou certo que há dificuldades e que pese que muitos de nossos juristas foram formados na escola de direito a serviço da classe hegemônica. Creio que vamos mudar a mentalidade política, temos que mudá-la, estamos obrigados a mudá-la porque se os povos lançam o direito longe porque chegam à conclusão de que não serve, uma ferramenta inútil, o que fica é a violência e a violência tem hoje três inconvenientes insalváveis: um, se ficar o potencial tecnológico de destruição perdemos; outro, é que ainda que ganhemos sempre podemos um maior número de cadáveres e o terceiro é que ficam feridas que tardam gerações para cicatrizar. O único caminho que nos fica é outro, é o caminho da racionalidade, um caminho de uma racionalidade em um mundo irracional, em um mundo raríssimo, estranho, em um mundo que como diria Galeano parece estar de patas para cima, é um mundo estranho. Que querem que lhes diga, um mundo no qual em que a palavra mais revolucionária é a do Papa, é insólito, um momento raríssimo, o que querem que haja? Por isso temos que nos adaptar e ter em conta que o mundo mudou muito rapidamente, não estamos no século XX, estamos no século XXI, estamos em um século que temos 
muitas ameaças, incluso a ameaça de destruir a habitabilidade humana nesse planeta, não planeta, por sorte o planeta não podemos destruir, mas sim podemos destruir o planeta como nossa casa. É uma civilização que já não é nem sequer o triângulo de [Robert] Merton que dizia que essa é a vitalidade entre o fim e os meios e então vai se fazendo um triângulo que chegam poucos, não, quando se sobe na ponta do triângulo encontram o nada, encontram que estão fabricando um ser, um homem consumista, um ser humano consumista nada mais que isso, que consome pensando que não há morte e ao apagar a morte, apaga a existência, apaga o limite. Estamos em um mundo que através dos meios massivos es está construindo um ser humano vazio, oco, incapaz de existência, incapaz de projeção e buscam qualquer coisa e como não vão ter horrores de conduta? Poucos, deveria haver mais, me assombra que há tão poucos. Creio que temos que refletir muito creio que isto que fazem vocês, isto de conservar identidade e memória, isto de permitir esse diálogo intercultural que temos em nossa América que tem uma riqueza cultural fantástica. História que um dia desde a América Latina, e não muito longe, nós vamos mandar uma mensagem civilizatória muito diferente a essa civilização planetária que nos produziu.

Breves comentários acerca da fala de Zaffaroni:

A memória de um crime tremendo, inclassificável. Recordar um genocídio é fazer algo pela humanidade. Fazer os mortos falarem. Está se repetindo... "Desplazados por estar atrasados en la acumlación original del Capital.” América: o lugar que reúne os marginais de todo o mundo. Primeira Guerra Mundial: potências reconhecem, mas encobrem porque a Armênia não é influente. A sociedade é dinâmica, acordemos! Muertos de subdesarollo, "genocidio por gotejamento que às vezes jorra!” Monopólio midiático e manobras no judiciário como a nova forma de se dar um golpe, em uma clara e manifesta alusão ao que estava ocorrendo no Brasil naqueles dias.

Marx dizia que o direito é instrumento das classes dirigentes. Hoje, para Zaffaroni, é das transnacionais. Parece-nos que o direito moderno, que vem se transformando ao longo dos anos e se alinha aos interesses mais novos da relação social do valor-dissociação (Scholz, 2016), é de partida uma antinomia patriarcal com falsa aparência de neutralidade jurídica na medida em que desde o Iluminismo a igualdade fetichista se pauta no homem enquanto sujeito do valor. Forma da mercadoria e forma do direito.

Violência, Racionalidade. Seria a violência uma necessidade da imposição da relação social que em momentos mais agudos de modernização intensifica a racionalização dos processos destrutivos e de morte com intuito de reorganizar, reconcentrar capitais? 
Borrar la muerte, borrar la existencia, disse Zaffaroni ao comentar sobre o vazio existencial de quem vive a vida se satisfazendo apenas pelo consumo de mercadorias, para onde vamos diante do hedonismo mercadológico virtual que parece atomizar ainda mais as pessoas?

Mais tarde, ao ler o breve texto “A realidade irreal” de Robert Kurz, quis pensar nessa provocação do jurista argentino sobre apagar a existência e apagar a morte. O pensador alemão aponta para a dúvida acerca da realidade da existência subjetiva como assunto popular da ficção científica e parte de perguntas como:

\begin{abstract}
Será que jazemos clinicamente mortos numa câmara refrigerada, e nosso cérebro pe manipulado por meio de estímulos eletrônicos que nos simulam a vida e a experiência? Ou será então que estamos sob o efeito de drogas que nos figuram um mundo repleto de vida, quando na verdade jazemos encolhidos em um canto fétido qualquer? A inquietante sensação de que a realidade pode ser interrompida a qualquer momento, como se alguém retirasse o plugue da tomada, penetrou abertamente até mesmo na consciência cotidiana. (Kurz, 1997ª 127)
\end{abstract}

O desenvolvimento do argumento que parte dessas perguntas vai juntando, pouco a pouco, relações cotidianas e a subjetividade "entre a existência e aparência, entre realidade e simulação” que se desdobram socialmente em lucros fictícios. Na tarefa de gestão civil do Estado em investimentos improdutivos, algo que ganha aparência de “custos operacionais”, a rentabilidade foi se tornando impossível historicamente. Para contornar o problema, o Estado carecia e carece de uma "simulação monetária e, por meio de crescente capital fictício do crédito governamental, sangrar seu imaginário futuro capitalista”. Porém, também esse mecanismo já demonstrou ser inviável ao longo da história quando o “encanto do 'milagre econômico’ foi quebrado pela revolução microeletrônica do final dos anos 70” abrindo novos caminhos em termos de racionalização produtiva. Tecnologia que cria abismos entre trabalho e moeda a mover relações sem substância nos termos do valor. A aumento da produtividade do trabalho por meio de renovação tecnológica implica em desemprego e redução de trabalho necessário e a tendencial queda da taxa de lucro ${ }^{36}$.

Nesse ponto que as ideias Zaffaroni e Kurz podem ter algo em comum, embora a formulação do primeiro não relacione esse vazio da existência tão diretamente à crise do sistema monetário e ao

36 Na segunda parte do texto trataremos sobre essa mudança histórica no sentido da acumulação de capital nos tempos atuais em diálogo com Scholz (2016), especialmente nos itens "Shushi, 10 outubro" e no item "Yerevan, 25 de novembro". 
momento histórico da moeda sem substância. Mas as ideias do jurista argentino apontam para a ausência de sentido que é a vida das pessoas mediada por coisas e voltada à finalidade, que não diz respeito às pessoas, de transformar um dinheiro em dois. Para Kurz:

\footnotetext{
Uma coisa é certa: os homens modernos de todas as classes sociais não querem admitir que, com o decorrer do tempo, uma economia totalmente monetária é inviável na prática. A despeito disso, a notável ‘cultura da simulação’ nos permite supor que a realidade capitalista tornou-se irreal. Talvez o indício mais forte do fim dessa realidade da aparência seja o fato de certos homens não se levaram a sério e nem mesmo saberem se realmente existem (Kurz, 1997a: 134).
}

Podemos ainda perguntar sobre qual papel jogam a existência enquanto aparência e a realidade enquanto simulação nas novas formas violentas de racionalização, nas novas formas de guerra virtual. Já não é ficção científica algum especialista sentado numa câmara refrigerada que controla remotamente drones a jogar bombas nos territórios em guerra. Apagar a morte real ao mesmo tempo que se apaga a existência virtual. E se a simulação é a trama cotidiana dos capitais fictícios, a moeda sem substância aparece como a mediação inexorável do capitalismo sem fim. Trataremos mais sobre esse problema e sobre a perspectiva teórica na parte seguinte do texto por outras entradas, ao pensar a acumulação de barbárie do decadente capitalismo atual.

Parece interessante ainda pensar armenidade hoje como simulação, seja em um evento em Buenos Aires, seja em qualquer outra cidade da diáspora ou até dentro da própria Armênia. Armênia e diáspora atualmente já consolidaram a separação e a simulação através do espetáculo, pensado aqui como “o capital a um tal grau de acumulação de que se torna imagem” (Debord, 1997).

Hoje não faltam eventos relativos às questões da armenidade e as abordagens variam desde a rememoração do Genocídio Armênio nas comunidades até eventos científicos, discussões sobre identidade, debates sobre a questão do direito, mas já não dizem respeito à sobrevivência ou à vivência entre pessoas com alguma identidade em comum.

A armenidade, como a vida sob o capitalismo contemporâneo, ganha contornos de uma irrealidade que se descolou da vida cotidiana para se afirmar no espetáculo das identidades. Esse movimento, aqui mais uma vez queremos nos posicionar criticamente em relação à ideia de (re)união através da cultura particularmente armênia, entrelaça os descendentes de armênios na assim chamada diáspora de todo o mundo e o país Armênia. Nesse ponto que as organizações internacionais armênias (UGAB, H.O.M., Fundo Armênia, são alguns exemplos disso) de cunho 
beneficente configuram algo como um clube internacional de crédito. A segunda parte do texto vai abordar esse problema também.

Assim, se a cultura segue parecendo genuína e se apresentando como totalidade da vida antes da modernidade, hoje a cultura não passa de uma mercadoria que produz discursos sobre a totalidade social, mais uma esfera autonomizada da modernidade. Debord usava uma ótima expressão para este mesmo problema ao dizer que a mercadoria produz seu monólogo laudatório. Uma mercadoria separada que produz discursos sobre a totalidade social da qual faz parte enquanto parte e não como todo.

Victoria Montenegro, filha de desaparecidos em 1976, fez uma fala apontando o tempo todo para a violência de Estado, a necessidade de memória, verdade e justica; e a possibilidade de se denominar os crimes pelo seu devido nome. Integrante das Mães da Praça de Maio que, em seu entendimento, converteram os espaços de morte em espaços de vida. Vítima dos sinistros sequestros perpetrados pela Ditadura Argentina, Victoria disse que estamos “luchando pelas mesmas consignas” ao referirse sobre os massacres genocidas planejados e executados pelo terrorismo do Estado moderno. Não vamos comentar a breve fala exposta a seguir. Optamos pelo registro da transcrição aqui também para dar um quadro mais amplo sobre quais ideias estão circulando nos debates sobre Genocídio Armênio.

Transcrição comentada da fala de Victoria Montenegro em Buenos Aires, ato da Unión Cultural Arménia, dia 23 de abril de 2016.

[traduzido do áudio em espanhol arquivo pessoal do autor/tradutor]

Victoria Montenegro: (...) em nosso país, se entendia, se dizia, tentava-se instalar a ideia de que havia havido uma guerra e que sabiam que era guerra para andar a paz e que havia de xx o passado, a história havia que avançar. Pensando que era possível haver uma reconciliação, sim ter essa possibilidade de justiça e podíamos chamar as coisas pelo seu nome e podíamos colocar uma (visagra) de respeito pela vida, porque esse são os direitos humanos, isso é direito pela vida e pudemos ver em muitíssimos casos aos entes queridos e fazermos claro porque estava a escutar com muita atenção a todos os companheiros que falaram antes de mim que são todos partes da mesma história e como todos tem a ver com tudo, nosso país e em toda América Latina houve um enorme genocídio com centos de mil desaparecidos, mas a América Latina teve a coragem graças a mulheres e a muitíssimos que lhes acompanharam nesses anos de nome civil que foi ser buscado essa força comum, desenterrar e por a cada uma dessas pessoas seu nome e devolver os restos, 
necessitamos desse lugar de onde recordar-los, mas sobretudo de reivindicar a aparição de cada uma de suas histórias e os sonhos de cada uma dessas pessoas porque os genocídios que atravessaram gerações e aquelas pessoas que desapareceram não somente uma cifra, o que hoje lamentavelmente nosso país tenta questionar novamente as cifras como se isso pudesse justificar a ausência, como se isso pudesse justificar semelhante atropelo à vida. Não se trata somente das cifras que são horríveis porque uma só pessoa desaparecida é horrível, porque um Estado que entende as pessoas como pessoas que merecem viver e pessoas que não merecem viver é horrível. Nós tivemos a possibilidade de recuperar a muitos companheiros e fizemos mudanças, desenterramos essas tumbas e recuperamos, además, o sonho da vida e da luta e nos fizemos por esses espaços que eram de horror por serem espaços de nossos companheiros nós convertemos em espaço de vida, como também nos recordamos com música, cultura, com presença e com a juventude involucrada e todavia com sua história porque é muito importante sobretudo nessas épocas difíceis para a Argentina e para o mundo também donde que parece que temos naturalizado ver como morrem milhões pessoas salvadas, como os matam quando fecham as fronteiras, como novamente uma humanidade pensa que há pessoas merecem viver ou não de acordo com seu tom de pele ou a sua raça ou a como pensam e é importante que nós, os povos nos unamos nisto reivindicar isto a vida, a luta, os sonhos, o que nos move que tem a ver com a possibilidade de construir um futuro melhor para nossos filhos. Nós argentinos temos o orgulho de ser um exemplo do mundo, temos muito orgulho de haver respondido a pior forma de violência, a desaparição, ao roubo de bebês com mulheres realmente incríveis, elas não gostam que diga que são incríveis, nós que tivemos a possibilidade de recuperar nossa vida, nosso nome, nossa história, porque também tentar nos e impor uma identidade que não era nossa, nos criaram outro nome com outra data de nascimento e com outra ideologia que nos fazia odiar nossas próprias raízes, que nos fazia depreciar tudo o que estivera relacionado com a militância política, acento porque 500 bebês, mas não somente é o que marcamos sempre sobretudo com os mais jovens que nasceram na democracia e naturalizaram muitíssimos direitos, não fizeram isso de desaparecer 30.000 pessoas e roubar 500 bebês porque nós os 500 bebês éramos especiais de alguma maneira, sim entendiam que éramos geneticamente subversivos e que havia que "encalçar-nos” para que fôssemos pessoas de bem para a sociedade, mas o fizeram para instalar um modelo de país que muito pouquinhos fiquem com tudo e o resto jamais se pense protagonista de sua própria vida, jamais projete, jamais tenha sonhos, jamais se sinta orgulhoso de ter pátria. Sempre olhando um espelho que venha de outro lado que nunca tenha nosso reflexo e acontecia a muitos netos que não tínhamos dúvidas sobre nossa identidade, éramos totalmente convencidos que éramos filhos de esses apropriadores, mas sim buscávamos um reflexo que se parecera, que o entendíamos, que se obteríamos, que somos 
outros, são reflexos que claramente nunca é verdade. No meu caso menos porque (nomes dos pais adotivos) foram alemães, o que nunca vai chegar esse reflexo e digo às vezes me passa que maravilhoso estes anos, não? Porque os nenês quando vou às escolas, o primeiro que me perguntam, a primeira perguntam que fazem sempre é se eu não tinha dúvidas, sobre mentira porque para eles é lógico que os bebês que nasceram em 1976 até 1980 e que podem ser filhos de militares tenham dúvidas sobre sua identidade. Lhes conto que quando chego nas escolas, não a tantíssimos anos, mas para os jovens é um montão de tempo...não se falava disso e se fecha isso, em minha escola ao menos se falava para reivindicar a Ditadura militar e esso que se construiu que é enorme, é lindo e que tem a ver com o direito de todos, com esse piso de dignidade que temos todos os argentinos independentemente de seu posicionamento político, que não tem a ver unicamente com as mães, as avós é somente ou mesmo dos direitos humanos e sim que tem a ver com todos nós, com a possibilidade de um país que se fez a cargo de sua história, que pela primeira vez chamou suas coisas pelo seu nome, que não havia possibilidade de ter memória, verdade e justiça, que não permitiu aqui e agora vamos lutar para que continue, poder comprovar a responsabilidade dos que se esconderam de trás dos uniformes, dos interesses econômicos que sempre são os que levam adiante estes genocídios e poder começar a recordar-los e que a sociedade saiba do que se tratou a história porque só aí vamos poder entender que tudo tem a ver com tudo, que os mesmos que se esconderam detrás dos uniformes e suas empresas e tinham a responsabilidade direta por ser seus delegados, seus sindicalistas e aos mil esses eram perigosos porque esses eram contagiosos, havia que desaparecer a subversão porque ela é contagiosa porque tem a capacidade de contagiar a outro e fazê-lo crer que valia a pena estar vivo e que valia a pena lutar por essa pátria e que valia a pena por ser um país livre e soberano e nós nesses anos voltamos a ser contagiosos porque temos uma juventude que novamente se contagiou desses mesmo ideais, por isso é importante que lutemos juntos, cuidando de nossos jovens, afirmando e mantendo bem viva a memória, a verdade e a justiça estando atentos a isso que surge agora de querer instalar novamente a teoria dos dois demônios, de não chamar as coisas pelo seu nome resulta que o 24 de março em nosso país é um momento de tolerância, um período de tolerância quando na verdade sabemos que houve um genocídio e tudo o que vai se sucedendo, voltam às cifras, enquanto há a ideia de que os garotos voltem a repetir e a perder tempo nessas discussões que faz perder tempo quando discutíamos se estava bem ou mal se alguém merecia viver ou não. Construímos ao menos um piso de respeito pela vida que tem que ser de todos nós, por isso é tão importante que estejamos juntos nessa data que lhes amarga tanto, apesar da distância e apesar dos anos porque seguimos lutando pelo mesmo, seguimos repetindo as mesmas (consignas) $e$ seguimos também totalmente convencidos de que esses ideais e essa vida e esse sonho de todos 
aqueles que morreram lutando por viver em um país soberano sigam vigentes mais do que nunca, apesar das mudanças que muitas vezes que iriam ser positivas vemos com muita tristeza, sinceramente, que não é assim, apesar disso temos e estamos convencidos de que construímos um país melhor para todos, sempre dizemos aos garotos "estamos de que meus filhos e os filhos dos meus filhos vão nascer melhor pessoa que nós" e que nos toca agora é defender muito forte a memória e seguir reivindicando o que tem que ver pela verdade de todos nós todos os dias e abraçar fortemente a política de direitos humanos e seguir totalmente convencidos de que, sobretudo as coisas é claro, vale a pena viver, vale a pena estar vivo e vale a pena sempre e é necessário sempre recordar a cada um que dos que nos arrebataram, seus nomes, não, sua ausência, sua morte, recordar sua vida, seus sonhos e transmitir-los dessa maneira, com música, com esta irmandade e com esse firme compromisso para que nunca, nunca, nunca mais para os que pensam que nós ficamos no tempo, por que buscamos, porque sempre queremos o plano desse passado e não queremos avançar ao futuro, tudo ao contrário. Este passado a todos nos move profundamente e aos filhos é mau, claro, mas aos filhos passa algo bastante difícil que nós já somos muito maiores do que nossos pais, meus filhos já são maiores que seus avós quando eles desapareceram e não voltam nossos pais, nos voltam nossos pais, mas uma dor, uma mescla de dor de mãe com dor de filha. O fazemos porque somos masoquistas? Claro (por supuesto) que não, porque amamos profundamente a vida, porque amamos profundamente as novas gerações $e$ queremos que nunca, nunca mais alguém tenha que passar por isso novamente, nós fazemos ademais, porque como dizem os companheiros: “nossa vingança é ser feliz”. Por felicidade vamos seguir sempre por memória, verdade e justiça na luta dos povos. 
Entrevista com Maria Rosa y Alberto em Buenos Aires, 23 de abril 2016. Pós ato político na Praça Armênia, bairro de Palermo - Buenos Aires, Argentina.

A conversa se deu na língua espanhola e aqui reproduziremos traduzida para o português.

Maria Rosa: Em caso nosso, a família Adjinian e a familia Karamanian. A família Adjinian vinda de Tomarza foi corrida e meus avós paternos vieram, passaran por Alepo, por Síria e aí tivieran um filho em cada lado e já em 1929 terminaram nos Estados Unidos, corridos pelo Genocídio com os dois filhos. Nos Estados Unidos não os deixaram ficar por un problema de saúde da vista de minha avó e depois os mandaram e chegaram ao Brasil, mas Brasil tampouco os deixou estar e chegar a Argentina. Mas já vinham sabendo que na Argentina havia conhecidos de nossos avós, então terminaram no bairro de Soldatti onde havia uma igreja e se juntavan um montão de armênios. E aí havia uma igleja onde havia um montão de armênios já chegados a partir de 1915, do Genocídio. Então foi em 1929 e aí tiveram cinco filhos mais, todos argentinos, eu sou da segunda geração de argentinos e se dedicaram primero a armazém, a pôr um armacén de bairro, vender comida e depois de 10, 15 anos, más, 20 [anos] se dedicaran a sapataria, a fabricar sapatos. Porque é quando se foi aos Estados Unidos se foi porque havia um parente nosso que foi e que ficou e, depois como minha avó ficou viúva, foi que ajudou a seus filhos que podiam estudar. Lhes mandava grana (plata) e esses cincos filhos logram armar uma fábrica, fabricavam sapatos $e$ durou 50 anos quase. Agora já não está essa fábrica, mas bom lograram manter-se deste modo e por minha materna, a família Karamanian, vindo pelo lado da Grécia, era armênia, mas minha avó passou pela Grécia, por um orfanato porque ficou sem sua mamãe e depois eles vieram diretamente à América do Sul e terminaram também no mesmo bairro, Soldatti. Mas eles já não foram empregados, a via materna não lograr, a dizer, independizar-se, ter um comércio. Bom, nesse bairro depois todos os avós que vieram como primeira geracão fundaram uma igreja, um colégio, se manteve o que é o idioma. Eu estudei aí e hoje colaboro com este colégio, meus filhos estudam aí, ou seja, a história dos imigrantes, os italianos, os armênios, os españoles, todos corridos pela imigração em Soldatti e no bairro Flores.

Alberto: De parte minha tenho meus avós paternos... ambos são de Tomarza ${ }^{37}$ que atualmente é Turquía e... de parte materna. Meu avó paterno sempre foi de ofício carpinteiro e esteve aqui sua fábrica com seus filhos, meu pai...esta fábrica durou até vinte anos atrás mais ou menos, donde mi padre ainda vive tem 88 anos, mas seus irmãos já faleceran. Asim que já sou segunda geração e de parte materna, meus avós eram muito humildes viviam tambem no bairro de Soldatti, vieram também, toda migración dela foi diretamente à Argentina trazidos por uma irmã maior de minha avó que, esse irmão maior sim teve uma empresa hoje muito importante aqui em Buenos Aires que 
é a Fija Botijian (checar) de maioristas...são os que têm os “kioscos”. Essa pela parte materna, digamos. Eu não conheci a minha bisavó paterna que o único que podia falar ela era o turco, não sabia o idioma armênio. Seus antepassados por estar vivendo em território históricamente armênio mas em uma parte turca nos obrigavam a falar em turco.

Artur: Em Cilíca?

Alberto: Em Cilícia, não em Cilícia. Tomarza onde era?

Rosa: Tomarza não era Cilícia, Cesaria. Porque se conhece os mapas aparece como Cesaria.

Alberto: Essa é uma provincia turca, atualmente. Entonces, eu conheci minha bisavó e me acordo no dia de hoje que ela não falava armênio, falava turco. Foram superando, somos a segunda generação, nossos filhos foram a colégios armênios. A primeira parte fizeram no bairro de Soldatti e a parte secundária fizeram em Palermo na Unión Cultural Arménia de Benificencia (UGAB/AGBU) que é outra instituição armênia que é mundial.

Rosa: Agora colaboramos com essa insituição...

Alberto: Estamos colaborando porque sempre nossos pais foram quase fundadores desta instituição que é Unión Cultural Arménia e tem já 80 anos e sua primeira sede no bairro de Flores e outra sede aqui no bairro de Palermo. Era toda gente trabalhadora, gente lutadora, gente que se fez por baixo, digamos, e que estão apoiando constantemente a coletividade e têm suas escolas, suas igrejas, suas instituições culturais...

Rosa: ...por isso essa mirada porque é uma mirada política. Como nós... a un bem estar coletivo, para todos, não mirar a um só e que o outro não tenha. Por isso Unión Cultural Arménia segue os mesmo princípios que tinhaa quando fundaram os pais nossos e se identificava com a Armênia Soviética. Bom, hoje não esta a Armênia Soviética, mas, bom, seguem tratando de mantener seus valores.

Alberto: Viajamos a Armênia e vimos o que é a Arménia atualmente e se ve a cidade que é Yerevan que está muito avançada na parte comercial, mas há muita diferença social, há muita imigração... Rosa: Se vais aos povoados...

Alberto: Há muita diferença e muita pobreza no interior, ou seja, no é só o que se vê em Yerevan, senão todo o que ve no interior e muita imigração que se teve que ir porque no se tinha trabalho, não se tinhaa como sobreviver e já se vão à Rússia, se vem à América, aos Estados Unidos, ou seja, o que sofreram nossos avós estam sofrendo estes armênios em sua pele própria por esse sistema político que estão vivendo, como que a história se repete. 
Fotos da manifestação e marcha pelo reconhecimento do Genocídio Armênio realizada no dia 25 de abril de 2016 em Buenos Aires

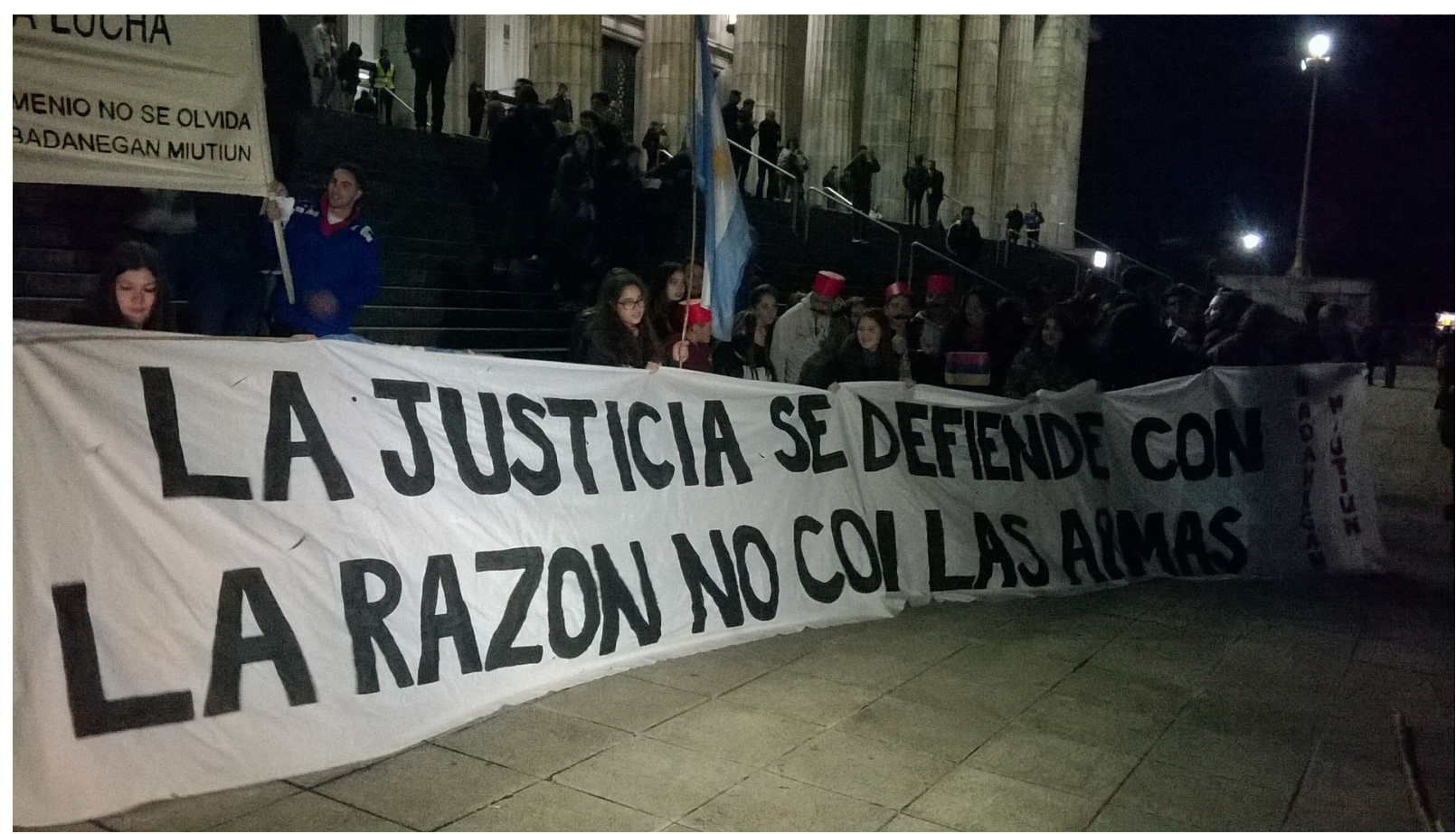

Foto 3 - Cartaz exposto em frente a Faculdade de Direito de Buenos Aires, Argentina no dia 25 de abril de 2016 na concentração para a marcha até o consulado turco. Artur A.C. Camarero.

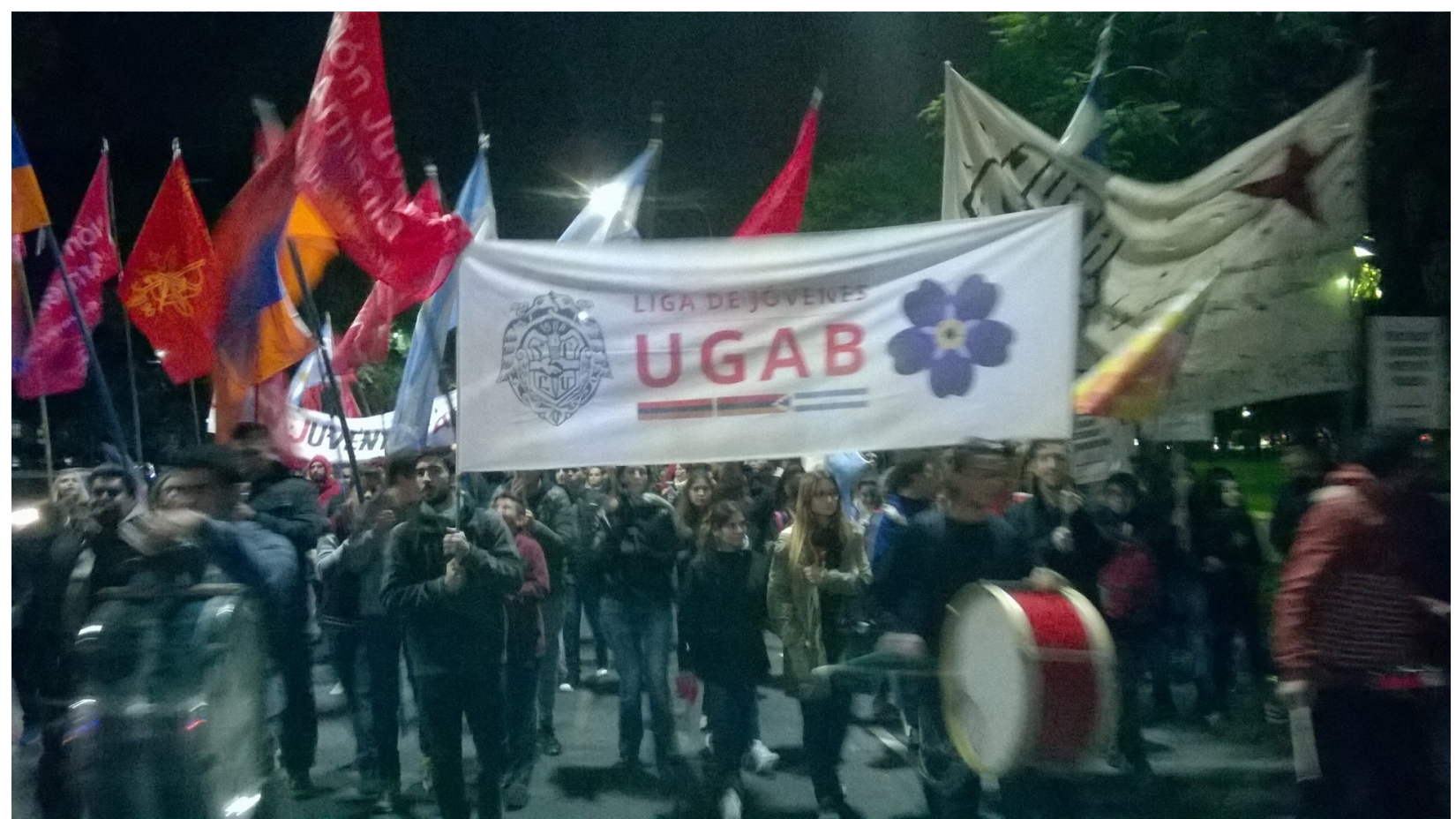

Foto 4 - Manifestação orientada por várias entidades da comunidade armênia de Buenos Aires, Argentina, que marchou da Faculdade de Direito até o consulado da Turquia da cidade onde foram proferidos protestos e provocações sobre vários problemas da conjuntura da Armênia, em especial a ofensiva de abril do Azerbaijão na região de Nagorno-Karabakh. Artur A.C. Camarero, 25 de abril de 2016 


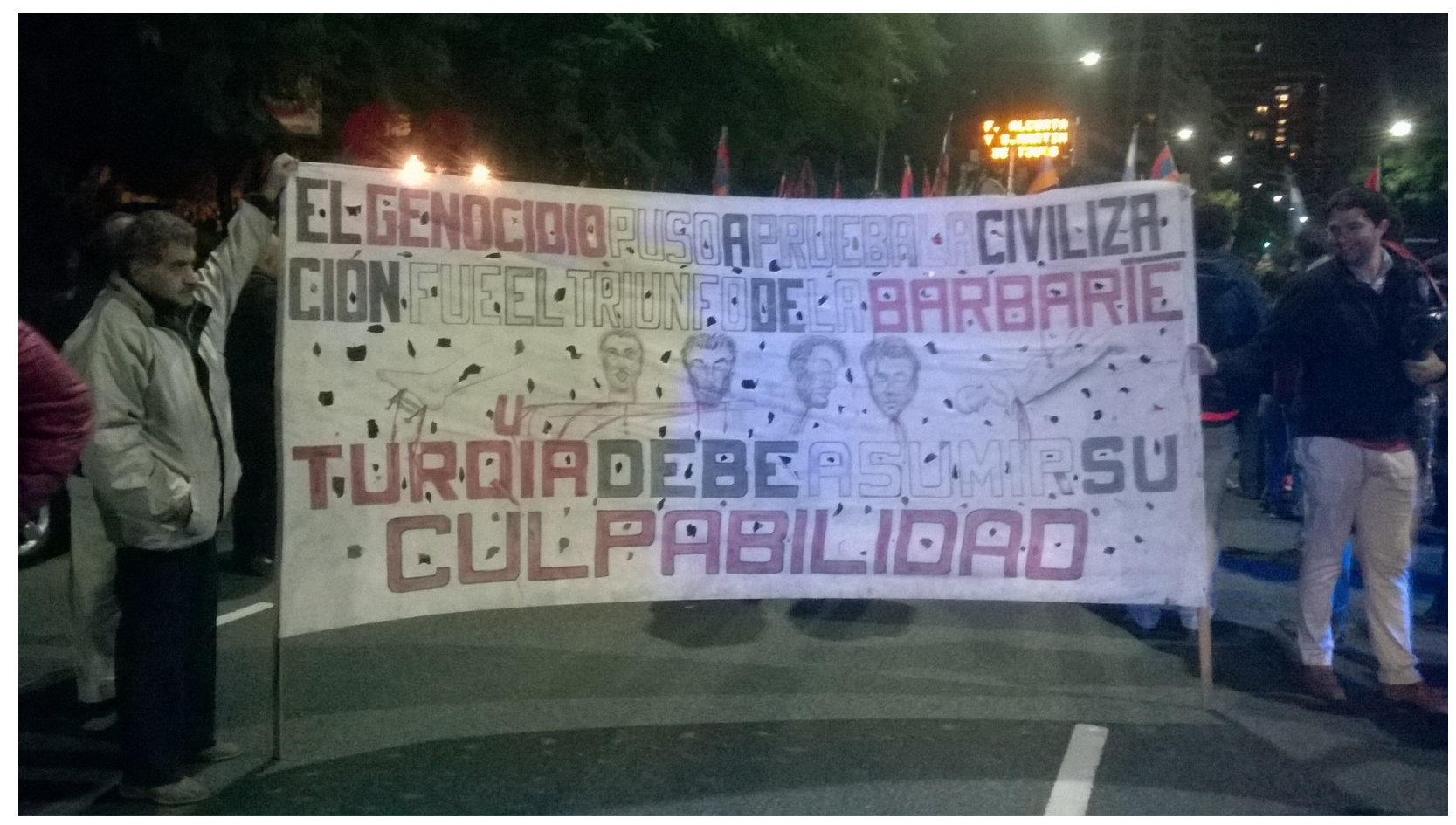

Foto 5 - Buenos Aires, Argentina. No cartaz se le em espanhol: "o genocídio pôs à prova a civilização foi o triunfo da barbárie. Turquia deve assumir sua culpabilidade”. Artur. A. C. Camarero 25/04/2016 
Buenos Aires, 28 de abril de 2016.

Ontem a tarde fui até a Fundación Luisa Hairabedian que fica próxima à Plaza de Mayo. Lá conheci Greta e Irina e a primeira havia reservado um tempo para nuestra charla, que foi bem boa, por sinal. Greta foi bastante atenciosa e me presenteou com o livro de Taner Akçam que a fundação traduziu e editou em 2010, um livro importante porque além de muito bem embasado, o autor é turco. Abordaremos o livro de Akçam na segunda parte do texto. Ganhei também um pôster calendário de 2013 com várias imagens de trabalhos escolares feitos em conjunto com a seção educativa da fundação, da qual Greta é coordenadora. São fotos e desenhos relativos à conscientização de temas duros da modernidade, entre eles: Genocídio (Armênia e Ruanda principalmente), violência contra a mulher, direitos humanos, desigualdade social, entre outros. Na conversa, logo no princípio, fui me apresentando já com minha “filiação teórica” junto Exit e o vínculo com Labur-USP. Tentei falar algo sobre quem foi Robert Kurz e quem é Roswitha Scholz, as publicações e ideias de cada um, falando da dissociação e da revisão do feminismo de Roswitha, da interpretação do Kurz no Colapso e a postura crítica de Kurz frente ao marxismo tradicional, mas ao mesmo tempo pelas categorias de Marx. Ela se demostrou interessada e disse que eu teria ótimos papos com Gregório Hairabedian, pai de Luisa e fundador da Fundación. Examinei a bibilioteca un rato e fui tirar cópias de dois livros de Brisa Varela ${ }^{38}$, que segundo Greta é o melhor que se tem sobre a imigração armênia para Buenos Aires. De lá fui até a Galeria Pacífico atrás da exposição dos imigrantes armênios no Centro Cultural Borges. Eram muitas fotos com legendas que, por isso, aqui dispensam maiores comentários. Optamos por algumas publicar algumas delas no intuito de compartilhar com outros pesquisadores da temática no anexo desta parte.

38 Há um artigo de 2007 bastante informativo e sintético de anos de pesquisa de Brisa Varela, em que a autora estabelece um estudo sobre imigração de mulheres armênias em comparação com a posição masculina, mostrando resultados a partir de três grandes séries de entrevistas, com gerações diferentes, sobre as diferenças e o papel da mulher armênia dentro da comunidade de Buenos Aires e, como em Grün analisa em São Paulo (1992) as estratégias de reprodução comunitária, casamento “engo-gâmico”, mas especialmente o lugar apagado da mulher na esfera cindida da reprodução da família. Além disso, vale dizer que há uma problematização entre a "autoidentificação” que prioriza a "etnicidade" sobre o gênero, o que a faz investigar sobre a "armenidade”. 


\section{Anexos PARTE UM}

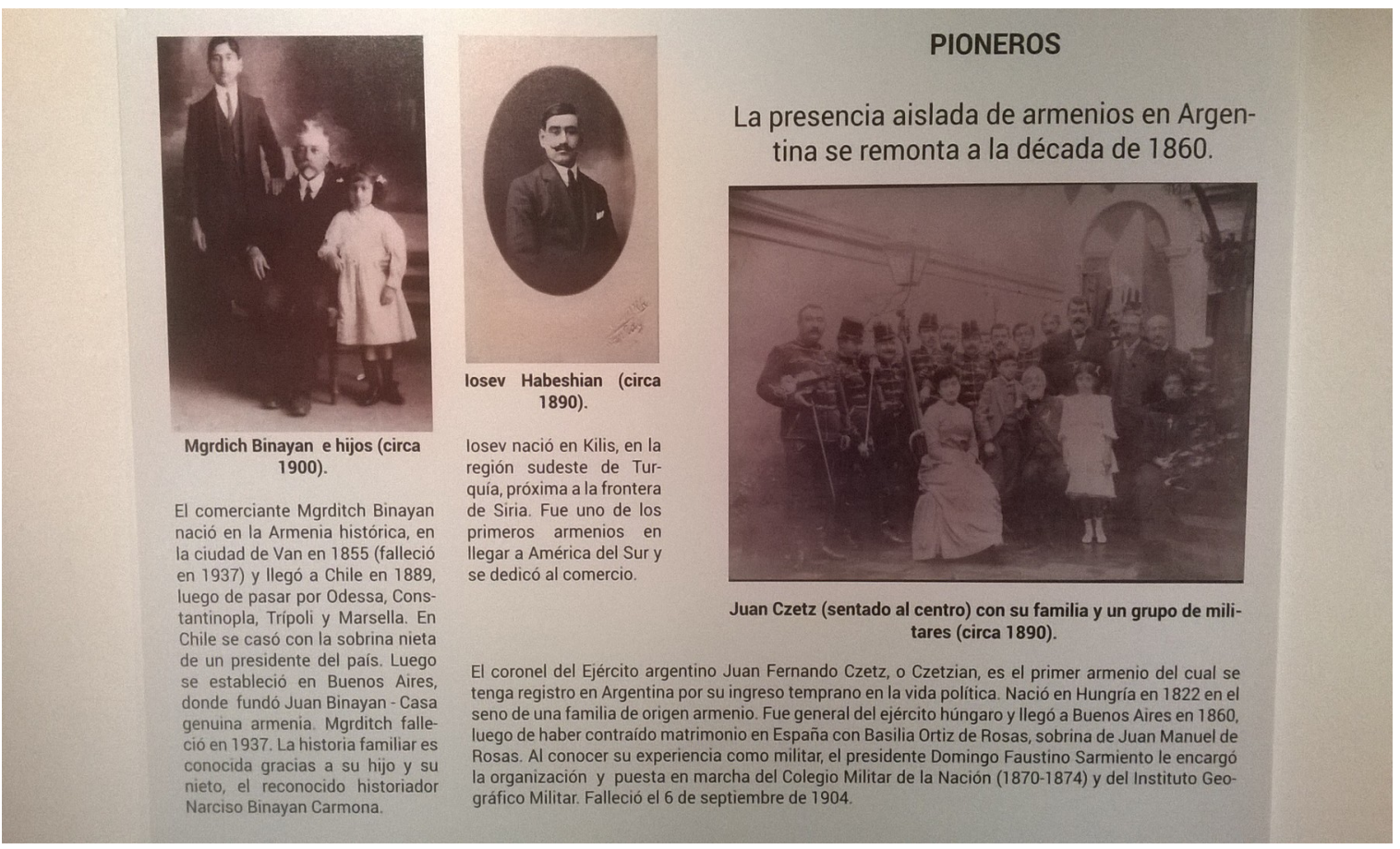

\section{$1^{\circ}$ OLEADA | DÉCADA 1910}

Un grupo limitado de armenios llegó a la Argentina en la década de 1910, en busca de mejores oportunidades de vida, probablemente huyendo a las persecuciones que precedieron al Genocidio.

Garabed Avdjian y su primo Jorge Bodorikian (circa 1913).

Garabed, originario de Rodosto (Tekirdag), llegó a Buenos Aires en 1911 e instaló una empresa de importación y venta de combustibles (carbón de piedra) denominada Barraca Agüero. Junto con su compatriota Jorge Patanian, dueño de Petrocar petróle y carbón y otros empresarios de -petróleo y carbon-, y otros empresarios del rubro, crearon la Corporación Argentina de Comerciantes de Combustibles.

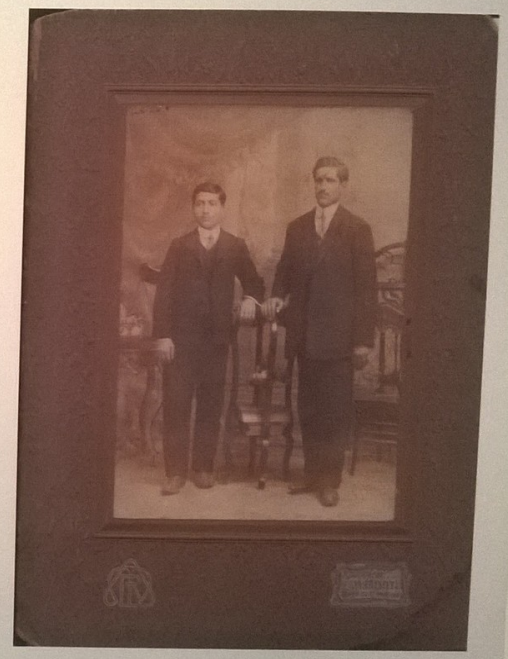


$2^{\circ}$ OLEADA | DECADA 1920-1930

Llegados al puerto de Buenos Aires, los sobrevivientes del Genocidio comenzaban a reconstruir sus vidas a partir de las oportunidades brindadas por el país receptor, una vez superados los controles sanitarios de la Dirección Nacional de Migraciones. Los que arribaron en estas décadas, encontraron una comunidad armenia que comenzaba a organizarse institucionalmente. En muchas ocasiones eran recibidos por sus compatriotas en el puerto de Buenos Aires, con la finalidad de ayudarlos a ubicarse y conseguir trabajo. Incluso, algunos eran conducidos a la calle San Juan 1537, donde se encontraba el Centro Colonial Armenio, antecesor del actual Centro Armenio, para recibir la ayuda necesaria.

Familia Markarian (Fotografia extraida del pasaporte emitido en Grecia para viajar a
Argentina) De pie, desde la izquierda: Zirair Markarian, Kohar Markarian y Bertz Marcarian. Sentados: Anni Tomburkdjian y Missak Markarian. La fa-

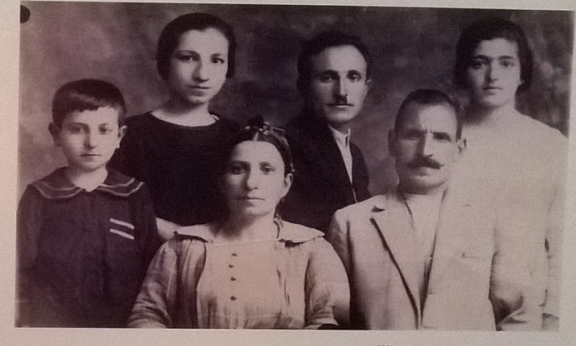

Familia Balassanian (1926)

Fotografía extraida del pasaporte antes de viajar a la Argentina.

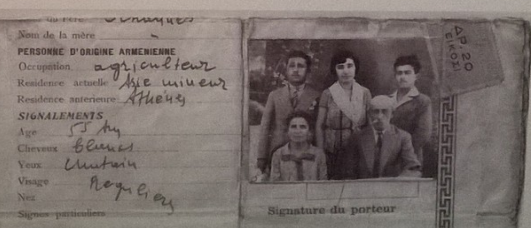

\section{$3^{\circ}$ OLEADA | DÉCADA 1940 - 1950}

Esta oleada esta constituida por armenios que no emigraron a la Argentina inmediatamente después del genocidio, sino que permanecieron en Turquía, más concretamente en Estambul, en Grecia, o bien en los países del bloque soviético. Algunos tomaron la decisión de emigrar poco antes de la segunda guerra mundial previendo los acontecimientos que se avecinaban. En el caso concreto de los armenios que se quedaron en Turquía, las políticas persecutorias continuaron pero tomaron otras formas. Una de sus expresiones fue la aplicación de impuestos elevados que los despojaron de sus bienes.

Integrantes de las familias Iskenderian y Sismanian, en Everek, circa 1928. (Foto de estudio).

De pie a la izquierda Satenik Iskenderian y a su lado su sposo Parsegh Sismanian Sentados de izquierda a derecha, Sultán Mghchian, la madre de Satenik, en el centro Bedig y Hagop, Ios hijos de Satenik y Parsegh (Yervant, el tercer hijo del matrimonio, aún no había nacido), y, a su lado Melcon Iskenderian, el padre de Satenik.

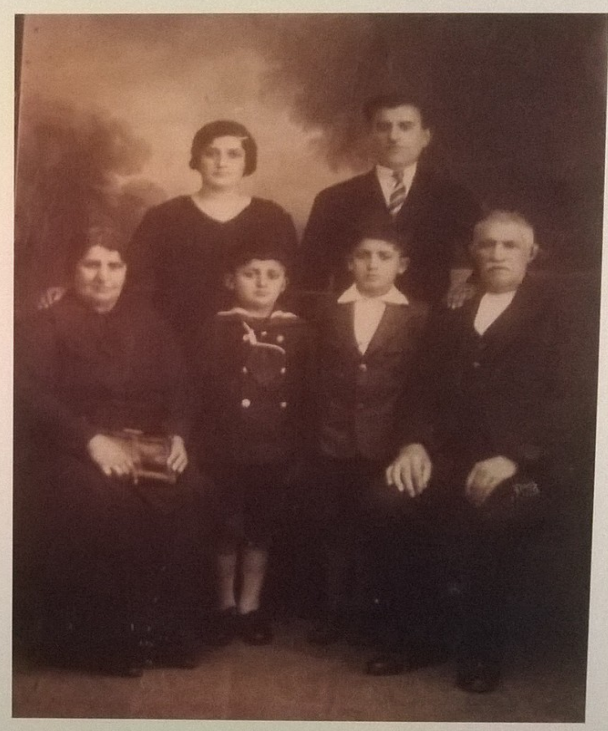




\section{$\underline{\text { ANEXO I }}$}

\section{HISTÓRICO DOS IMÓVEIS DA COMUNIDADE ARMÊNIA DE OSASCO}

HISTÓRICO DOS IMÓVEIS ONDE ESTA EDIFICADO A IGREJA APOSTÓLICA ARMÊNIA S.J.BATISTA, SALÃO SOCIAL, GINÁSIO, ESTACIONAMENTO E UMA CASA SEDE DA COMUNIDADE ARMÊNIA DE OSASCO CUJAS ESCRITURAS ESTÃO EM NOME DA IGREJA APOSTÓLICA ARMÊNIA DO BRASIL

\section{LOTES 56, 58 e 60 QUADRA 57 ÁREA 1.500,00M2}

Em 10.05.1935, a Igreja Nacional Armênia Apostólica de Presidente Altino, representados por:

SANASAR MARDIROS, AGOP GUZELIAN, PHILIPOS MAGDESIAN, JACOB MANUCHAQUIAN e KABRIEL SEFERIAN, adquiriram os lotes 56,58,60 da quadra 57, total de $1.500 \mathrm{~m} 2$ no bairro de Presidente Altino

Escritura lavrada no $3^{\circ}$. Tabelião de Notas de S.Paulo, livro 286, fls. 81-verso, transcrita sob n. 8.515 da $5^{a}$. Circunscrição e transcrição n. 4.660 da $9^{a}$. Circunscrição da Capital

Sobre o terreno foi edificado uma igreja e escola que recebeu o n. 498 da antiga Rua Erasmo Amaral, atual Rua Carlos da Costa Ramalho Jr. n. 502.

Em 12.07.1973, a Igreja Nacional Armênia Apostólica de Presidente Altino, representado por SANASAR MARDIROS, AGOP GUZELIAN, PHILIPOS MAGDESIAN, JACOB MANUCHAQUIAN e KAPRIEL SEFERIAN, através de escritura de venda e compra lavrada no $10^{\circ}$. Tabelião de Notas Nobre da Capital, livro 709, fls. 40, venderam o imóvel por Cr\$15.000,00 para COMUNIDADE DA IGREJA CATOLICA APOSTOLICA ARMENIA DO BRASIL, escritura transcrita sob n. 17.686 do $16^{\circ}$. Cartório de Registro de Imóveis de S.Paulo.

\section{LOTE 54 QUADRA 57 ÁREA 500,00M2}

Em 23.01.1962, RAPECA AZADIKIAN e CARAHIN AZADIKIAN, através de escritura lavrada no $3^{\circ}$. Tabelionato de Notas da Capital, livro 141, fls. 10, através do procurador SDEPAN BOYADJIAN venderam o lote referido para COMUNIDADE DA IGREJA CATOLICA APOSTOLICA ARMENIA DO BRASIL, escritura registrada na transcrição 25.613 do $16^{\circ}$. Cartório de Registro de Imóveis de S.Paulo.

Encontra-se edificado o ginásio de esporte e parte do jardim da igreja com frente para a Rua Carlos da Costa Ramalho Jr. 498 


\section{LOTE 52 QUADRA 57 ÁREA 500 M2}

Em 29.04.1968, RAPECA AZADIKIAN, através de Escritura de Cessão de Direitos de Meação e Herança, no valor de R $\$ 10.000,00$, NÃO LEVADA A REGISTRO, cedeu os direitos sobre o lote de terreno para o CONSELHO ADMINISTRATIVO CENTRAL DA IGREJA APOSTOLICA ARMENIA DO BRASIL.

Imóvel foi adquirido pelo cedente em 10.11.1949, esta registrado na transcrição 5.923 do $16^{\circ}$. Cartório de Registro de Imóveis da Capital.

Encontra-se edificado o ginásio de esporte e parte dos jardim da igreja com frente para a Rua Carlos da Costa Ramalho Jr. 498

\section{4. (parte) dos LOTES 31 e 33 DA QUADRA 57 ÁREA 400,00M2}

Em 25.09.1968, SARKIS GULUDJIAN e YEPRAKSY GULUDJIAN, venderam através de escritura de venda e compra lavrada no $1^{\circ}$. Tabelionato de Notas de Osasco, livro 96, fls. 3-B e retificada em 27.05.1970, livro 31 fls. 33 do mesmo Cartorio de Notas, parte dos lotes acima para a COMUNIDADE DA IGREJA CATOLICA APOSTOLICA ARMENIA DO BRASIL . Escritura registrada na Transcrição 4055 do $1^{\circ}$. Cartório de Registro de Imóveis de Osasco

Encontra-se edificado o ginásio de esportes com frente para a Rua Carlos da Costa Ramalho Jr. 498

05. (parte) dos LOTES 35 e 37 DA QUADRA 57 ÁREA 400,00M2

Em 26.11.1968, JEAN KURKDJIAN E SUA MULHER, venderam através de escritura de venda e compra lavrada no $1^{\circ}$. Cartório de Notas de Osasco, livro 15, fls. 79 e retificada em 25.05.1970, livro 31 fls. 33 do mesmo Cartório de Notas, parte dos lotes acima para a COMUNIDADE DA IGREJA CATOLICA APOSTOLICA ARMENIA DO BRASIL. Escritura registrada na transcrição 4054 do $1^{\circ}$. Cartório de Registro de Imóveis de Osasco.

Encontra-se edificado o ginásio de esporte com frente para Rua Carlos da Costa Ramalho Jr. 498

\section{LOTE 47 e METADE DO LOTE 49 DA QUADRA 57 ÁREA 750,00M2}

Em 22.11.1991, HAROUTIUN SEFERIAN, através de escritura de DOAÇÃO lavrada no $1^{\circ}$. Cartório de Notas de Osasco, livro 365, fls. 235, procedeu a doação do imóvel acima para a COMUNIDADE DA IGREJA APOSTOLICA ARMENIA DO BRASIL. Escritura registrada na matricula 7.830 do $2^{\circ}$. Cartório de Registro de Imóveis de Osasco.

Terreno do estacionamento com frente para a Rua Albino José Freixeda 


\section{LOTE 51 DA QUADRA 57 ÁREA 375,00 M2}

Em 25.05.1998. HAROUTIUN SEFERIAN através de escritura de venda e compra lavrada no $2^{\circ}$. Tabelionato de Osasco, livro 403 fls. 31, comprou e posteriormente vendeu pelo mesmo valor o referido imóvel para a COMUNIDADE DA IGREJA APOSTOLICA ARMENIA DO BRASIL. Escritura registrada na matricula 10.738 do $2^{\circ}$. Cartório de Registro de Imóveis de Osasco.

Sobre o terreno está edificada uma casa sob n. 437 da Rua Albino Jose Freixeda

Obs: Compra efetuada graças a recursos financeiros originários de doação recebida UNIÃO COMPATRIOTA DE SIS cujo dinheiro teve origem da venda de uma casa edificada sob terreno com 500m2 localizado na Rua Armenia que era de propriedade de União Compatriota de Sis.

\section{ÁREA TOTAL $\quad 4.425,00 \mathrm{M} 2$.}

Pesquisa efetuada por Dr. Missak Khachikian 


\title{
PARTE DOIS - No relógio 19:15, passados mais de 100 anos em guerra
}

\author{
"Cada um de nós devia contar algo \\ fantástico de sua própria vida, mas, \\ como a habilidade de narrar não é dada a \\ todos, não implicávamos com o aspecto \\ artístico da narrativa. Também não \\ exigíamos provas. Se o narrador dizia \\ que o fato narrado tinha realmente \\ acontecido com ele, acreditávamos ou, \\ pelo menos, fingíamos acreditar. Era essa \\ a etiqueta." \\ Águia Branca, \\ conto de \\ Nikolai Leskov
}




\section{1) Yerevan, 03 de outubro}

Depois de um final de semana agitado e dias longe da caneta, é tempo de retomar a escrita para não ser traído pela memória. Ontem, domingo, Marina e eu decidimos ir até o Lago Sevan de carona, pois ela ainda não tinha visitado suas águas azuis. Na noite anterior pesquisamos em qual avenida deveríamos nos posicionar para pedir carona. Na manhã seguinte, depois de um desjejum com iogurte, geléia, pão com manteiga e café preto, colei duas folhas de caderno e Marina escreveu Sevan Lidg (Lago Sevan em armênio transliterado).

Na estrada que também é caminho a Tbilisi e já quase no município de Abovyan, logo parou um homem que queria fazer o trajeto por dinheiro e na comunicação precária de meu hayeren (armênio) me fiz entender que queríamos carona e não serviço de táxi. Minutos depois uma van parou e iniciei uma conversa em armênio, mas logo o motorista nos disse, em inglês, para entrarmos, que não era um táxi e que poderíamos voltar com eles. Eles formam uma equipe de mergulhadores da “ArmDive”, dois homens nos bancos dianteiros e Lusine e Sona nos bancos traseiros. Conversamos na ida e na volta em inglês, as moças eram filhas do colapso, ou, da independência da Armênia em 25 de setembro de 1991. A equipe estava indo ao Lago para coletar lixo no fundo do corpo d'água. Não vimos o resultado final, mas nos disseram que há uma quantidade enorme e que o trabalho nunca acabará uma vez que as pessoas seguem jogando lixo no Lago. 


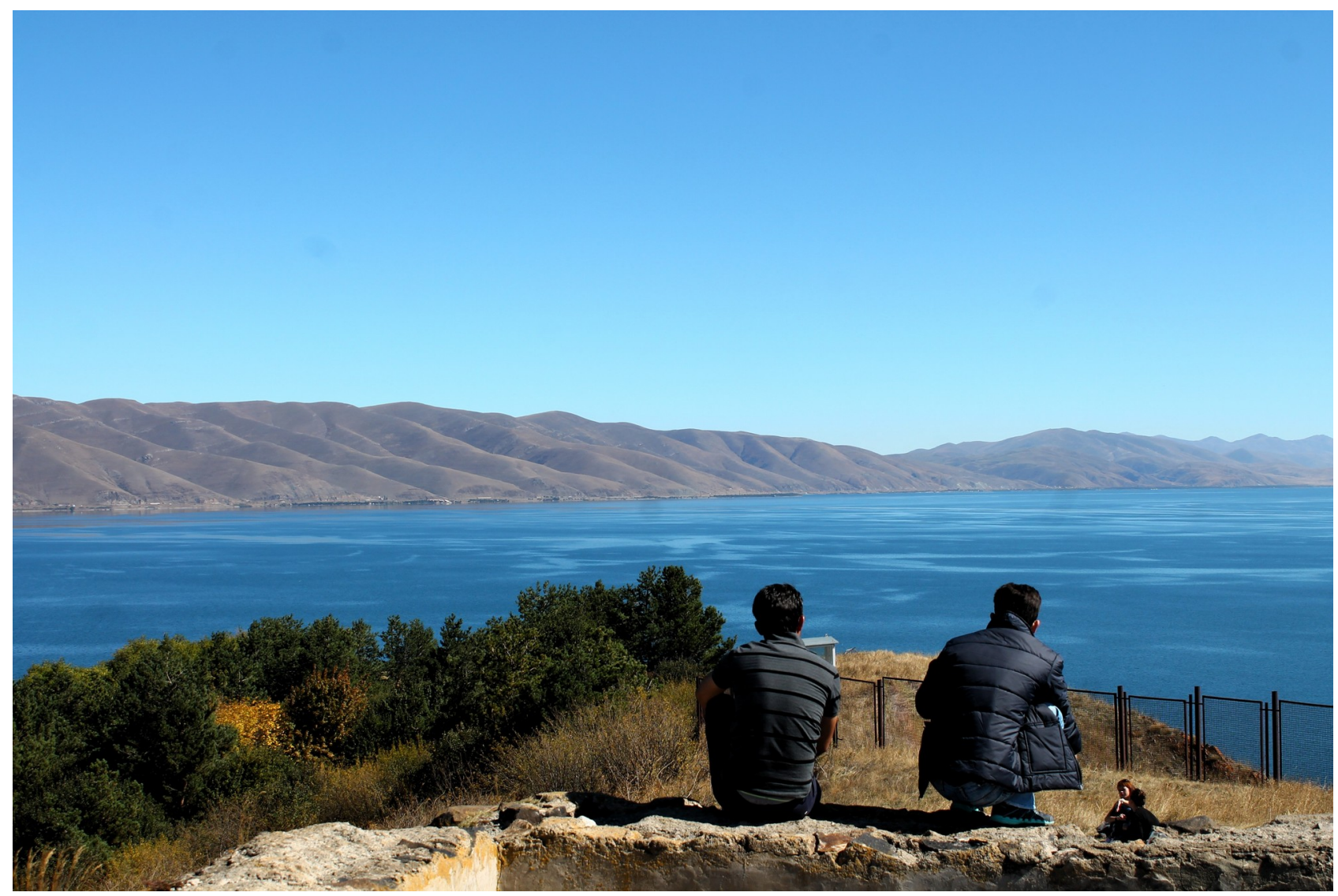

Foto 6 - As águas azuis do Lago Sevan, principal opção de verão na Armênia - país sem saída para o mar. Os reservatórios Spandarian e Kechut ao sul levam água ao Sevan por túneus e alimentam o lago que libera águas ao rio Hrazdan com seis hidrelétricas: Sevan, Hrazdan, Argel, Arzi, Kanaker e Yerevan. Marina Thaler Machado em 03/10/2016

Voltamos às 19:30 e encontramos com Charlie, nosso amigo britânico, para saborear algumas cervejas “artesanais” no chic Dargett, que se situa na rua Aram. Razmig, australiano amigo, mais tarde se juntou a nós, tomou uma cerveja e foi ao cinema. A cerveja sazonal de trigo com sabor de damasco é shat lav (muito boa)! A saideira foi na praça onde o rapper Kanye West nadou em sua visita à cidade acompanhando sua esposa, a socialite Kim Kardashian que é descendente de armênios e vive em Los Angeles. Com um litro de Kilikiana na garrafa plástica, a cerveja lager mais popular da Armênia, nos sentados no banco da praça que fica entre a Tashir ou Northen Avenue ${ }^{39}$ e a Ópera. Poucos minutos e Ana chegou até nós, uma armênia de meia idade que puxou conversa com o trio de estrangeiros perguntando justamente se não éramos armênios. Ela se apresentou, logo depois literalmente, como artista, poeta no idioma russo e cantora com um ritmo incomum. Conversa vai, conversa vem e não demorou para ela nos mostrar seus números musicais. Enquanto cantava estalava habilmente seus dedos em forma de acompanhamento rítmico. A primeira canção foi cantada em espanhol. Depois veio“Lullaby of birdland” cheia de scat singins que impressionaram e, por fim, Ana entoou uma canção egípcia que foi precedida por uma 39 Essa avenida é um calçadão de marcas chiques que liga a Praça da República com a Ópera, segundo alguns informantes a avenida foi toda "requalificada" nos últimos anos e grande parte dos capitais dessa "requalificação" vieram do Irã. 
descrição nada humilde de suas qualidades como cantora em diversas línguas, inclusive em árabe, mas também em inglês, espanhol, russo e armênio... Ana, que durante sua apresentação tomou uma dose de oghi (vodka caseira que muitas vezes passa os 70\% de gradação alcoólica), se dizia uma pessoa solitária nesse país, que precisava voltar à Rússia para lançar seus poemas no idioma local e surpreender o público. Quando perguntada sobre sua produção em armênio, nos disse que fazia poemas eróticos, mas não pornográficos, na sua língua de origem. Contou também de sua formação e convivência com gente de todo o mundo numa casa de estudantes em Moscou há vinte e tantos anos. O frio apertava e já era tarde. Decidimos ir para casa, mas antes Ana pediu trocados para mais uma vodka, não tínhamos moedas, mas Charlie, ligeiramente incomodado, cedeu uns trocados.

Situações cotidianas como essa foram vivenciadas ao longo dos três meses e alguns dias vividos como voluntário spyurqhay (armênio da diáspora) através do programa BirthRight Armenia $^{40}$, dedicado a descendentes de armênios em todo mundo abaixo dos 32 anos idade.

No sábado fizemos uma excursão para monastério de Khor Virap, a formosa vila de Areni e o monastério de Noravank entre seus cânions. Gancho para o relato das cavernas ocupadas por estudos arqueológicos na entrada do impressionante canyon de Noravank. Ali foi encontrado o assim anunciado "primeiro sapato” que se tem notícia e a narrativa armênia é orgulhosa pelo "fato” de o sapato "ser armênio”, mesmo que sua datação indique que ele possui mais de 5.500 anos. A caverna da armenidade pioneira não apenas detinha o primeiro sapato, mas também, e há quem se gabe do fato, do "primeiro vinho” que naturalmente é interpretado como armênio. Está sendo feito um trabalho de arqueologia na caverna e lá estão jarros milenares que dão “indícios” de uma produção de vinho por causa de sementes de uva que sobreviveram ao tempo depositadas no fundo dos grandes jarros

Verdade ou lenda, que importa? O verdadeiro é momento do falso na sociedade do espetáculo (Debord, 1997). A memória e a narração são feitas por escolhas e omissões, ressaltando o que quer ressaltar o narrador; tragédia ou heroísmo interessam mais do que o fetichismo cientificista da tal "verdade", pois como bem disse Walter Benjamin depois da guerra de 1914 “a arte de narrar está definhando porque a sabedoria - o lado épico da verdade - está em extinção” ${ }^{41}$. A posição social presente nos relatos, que dá relevo a situações banais do dia a dia, talvez mostre simplesmente a miséria da experiência e a dificuldade de narrá-la.

40 A “missão” do programa segundo o site oficial (traduzido do inglês): Nossa missão é fortalecer os laços entre a pátria e a juventude da diáspora, oferecendo-lhes a oportunidade de fazer parte do cotidiano da Armênia e contribuir para o desenvolvimento da Armênia através do trabalho, estudo e experiências de voluntariado, ao mesmo tempo que desenvolve laços pessoais duradouros e uma renovação do sentido da identidade armênia.

41 Benjamin, 1994b:201 


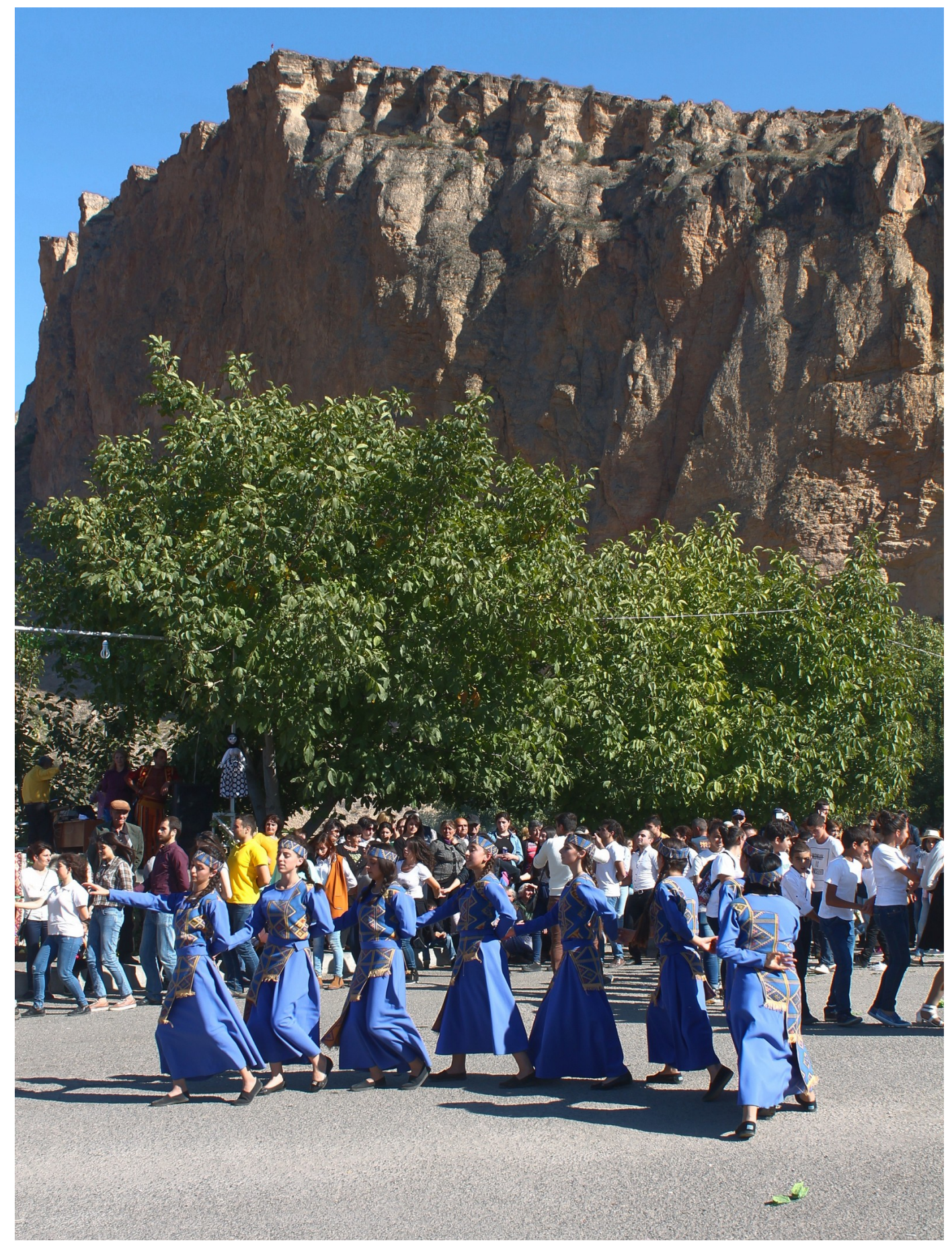

Foto 7 - Em Areni estava ocorrendo um festival para promover os vinhos regionais que acabou movimentando também o comércio de frutas, pães, mel, oghi (vodka caseira), khorovatz (churrasquinho) entre turistas e pessoas de todas as idades e no meio de toda essa festa grupos de danças tradicionais armênias. Tudo patrocinado por uma agência chamada "Global Credit". Aqui, como no Brasil, a cultura depende de excedentes do capital financeiro para se afirmar. Artur A. C. Camarero em $1^{\circ}$ de setembro de 2016. 
Novamente, as coisas tomam características dos processos de trabalho, características pessoais, mais ainda, características de uma imaginário nacional que vem sendo organizado para tais fins apenas durante o século XIX. A hipostasia do Estado nacional, da nacionalidade é ponto passivo para a coleção de elementos tidos como unicamente armênios e que formam essa nação imaginada antes até da era cristã. Vale dizer que os elementos de representação dos armênios nascidos na Armênia e da comunidade armênia em vários pontos do mundo, a assim chamada diáspora, nem sempre são coincidentes.

A literatura que trata da história da Armênia remonta a períodos anteriores à era cristã, de forma a encontrar nestes períodos pré-modernos os elementos constitutivos da armenidade ${ }^{42}$. Mais do que isso, a concepção de nação, Estado e povo armênio são hipostasiadas, tornando o que é relativo à relação-capital, à modernidade, um absoluto que atravessa o tempo. Esta literatura releva o que de certa forma pode ser compreendido como uma “formação armênia” a partir de dois momentos longínquos e que permitem uma leitura trans histórica, ainda que o segundo momento seja decorrente do primeiro. O primeiro diz respeito a uma espécie de história territorial. Tal interpretação parte do planalto armênio ou “Armênia Histórica” como habitat do povo armênio, território original e sempre ocupado pelos armênios. Como demonstra Porto ${ }^{43}$ :

A região da Armênia não possui limites claramente definidos, entre outras razões devido aos diferentes formatos que a nação, sempre que independente, assumiu ao longo da sua história. Convencionalmente, os armênios reivindicam como "Armênia Histórica" a área delimitada ao norte pelos Montes Cáucasos, a leste e o oeste pelos mares Cáspio e Negro e ao sul pela alta Mesopotâmia, entre o alto Rio Tigre e Rio Eufrates. Para tanto, utiliza-se como referência o relato do historiador grego Heródoto, do século $\mathrm{V}$ a.C., um testemunho ao qual a comunidade remete com orgulho tanto pelo reconhecimento que a fonte possui - inclusive dentro do meio acadêmico quanto por sua ancestralidade. (PORTO, 2011: 17)

Seguindo esta interpretação, o reino Urartu, que data por volta do século IX a.C., seria a origem do que veio a ser o povo armênio. A literatura que trata deste momento de formação lança mão de elementos culturais que vão desde a cerâmica milenar a uma suposta invenção do vinho atribuída aos ocupantes da “Armênia Histórica”. Posteriormente a região passa por domínios diversos, entre persas e romanos. Narrativas míticas apresentam o domínio de Dikran, o Grande, como o momento áureo da assim chamada nação armênia.

42 De acordo com PORTO: A “armenidade” - ou seja, os parâmetros a partir dos quais os indivíduos caracterizam a sua identidade armênia - varia de acordo com os sujeitos implicados e com o contexto no qual ela é empregada (PORTO, 2011: 6).

43 Vale dizer que Pedro Bogossian Porto em sua dissertação de Mestrado em Antropologia pela Universidade Federal Fluminense inicia a parte do texto dedicada à história dos armênios do Império Otomano dizendo: “Ao tratar da história dos armênios no Brasil é preciso evitar, sob risco de referendar um discurso que naturaliza a existência da nação armênia, a armadilha de retornar indefinidamente ao passado para tentar localizar as ‘verdadeiras raízes’ do grupo, como fazem seus principais relatos” (PORTO, 2011: 17). 
O segundo recorte transhistórico de formação da nação armênia se apoia nas características culturais específicas, a religião cristã e a língua armênia, diferenciando os armênios das demais etnias desde muito tempo. A adoção do cristianismo ocorreu durante a dinastia dos Arsácidas, sob o comando de Dertad III, no ano de 301 d.C. ${ }^{44}$ Assim, Armênia é entendida como o primeiro reino cristão do mundo e isso é significativo e significante do ponto de vista da construção de uma identidade nacional, uma vez que esse momento é bastante referenciado nos depoimentos e documentos produzidos pela comunidade (PORTO, 2011: 18). Outro pilar da formação da armenidade trans histórica é o alfabeto armênio que, segundo Porto, foi criado pelo monge Mesrob Mashdots que, por encomenda do rei Vramshabuh, formatou os caracteres da língua armênia a partir do ano de 406 d.C. O alfabeto, além de diferenciar os armênios junto aos demais povos da região, é entendido como um elemento fundamental para a identidade armênia, pois é responsável pela resistência e transmissão de uma cultura milenar (PORTO, 2011: 18).

A questão da identidade armênia é muito presente na literatura que trata da história da Armênia (ARLEM, 1978; FREITAS, 2001 e SAPESIAN, 1988 e 1997). Entretanto, nosso estudo entende que essa leitura naturaliza categorias que são próprias da forma de pensamento da modernidade, justamente pelo caráter abstrato da relação-capital, que enxerga e “encaixa” suas categorias de pensamento em formações sociais qualitativamente distintas.

Cotidiano e mito de formação da armenidade estão entremeados nos relatos justamente para mostrar como esses conteúdos foram presentes em nossa experiência e nos saltam à vista seja na personifcação de spyurqhay, voluntário, professor ou turista. Nosso acesso à Armênia deveu-se ao trabalho voluntário junto a uma organização que é bancada majoritariamente pelo capital estadunidense da assim chamada diáspora armênia. Será o trabalho voluntário mais uma expressão contemporânea da mobilização geral em uma sociedade do trabalho em ruínas?

44 Sapsezian descreve Gregório e seus feitos assim:

Gregório - sempre segundo as fontes tradicionais - seria o próprio filho de Anaque, assassino do rei armênio Khosrove. Criado e educado num meio cristão em Cesaréia, na Capadócia, Gregório retorna ao país e reintegra-se na corte do rei Dertade. Por causa de suas fortes convicções cristãs, porém, cai na desgraça do soberano e é encarcerado em uma gruta não longe da capital Ardashade. A intransigência de Dertade quanto aos adeptos da fé cristã transparece em outras tradições da época; por exemplo, toda uma comunidade de religiosas - entre as quais a abadessa Gaianê e a formosa Hripsemê - foi dizimada pela fúria real. Dertade é finalmente punido pelos céus e acometido de grave e humilhante enfermidade. Ocorre, a esta altura, a providencial intervenção de Gregório: resgatado da gruta onde penava há 15 anos, usa o poder do Evangelho para restaurar prodigiosamente a saúde do soberano. A cura de Dertade, seguida de sua conversão - e de sua corte -, constitui o marco daquela extraordinária virada que fez do cristianismo a religião do país. (Sapsezian, 1997: 24-25) 


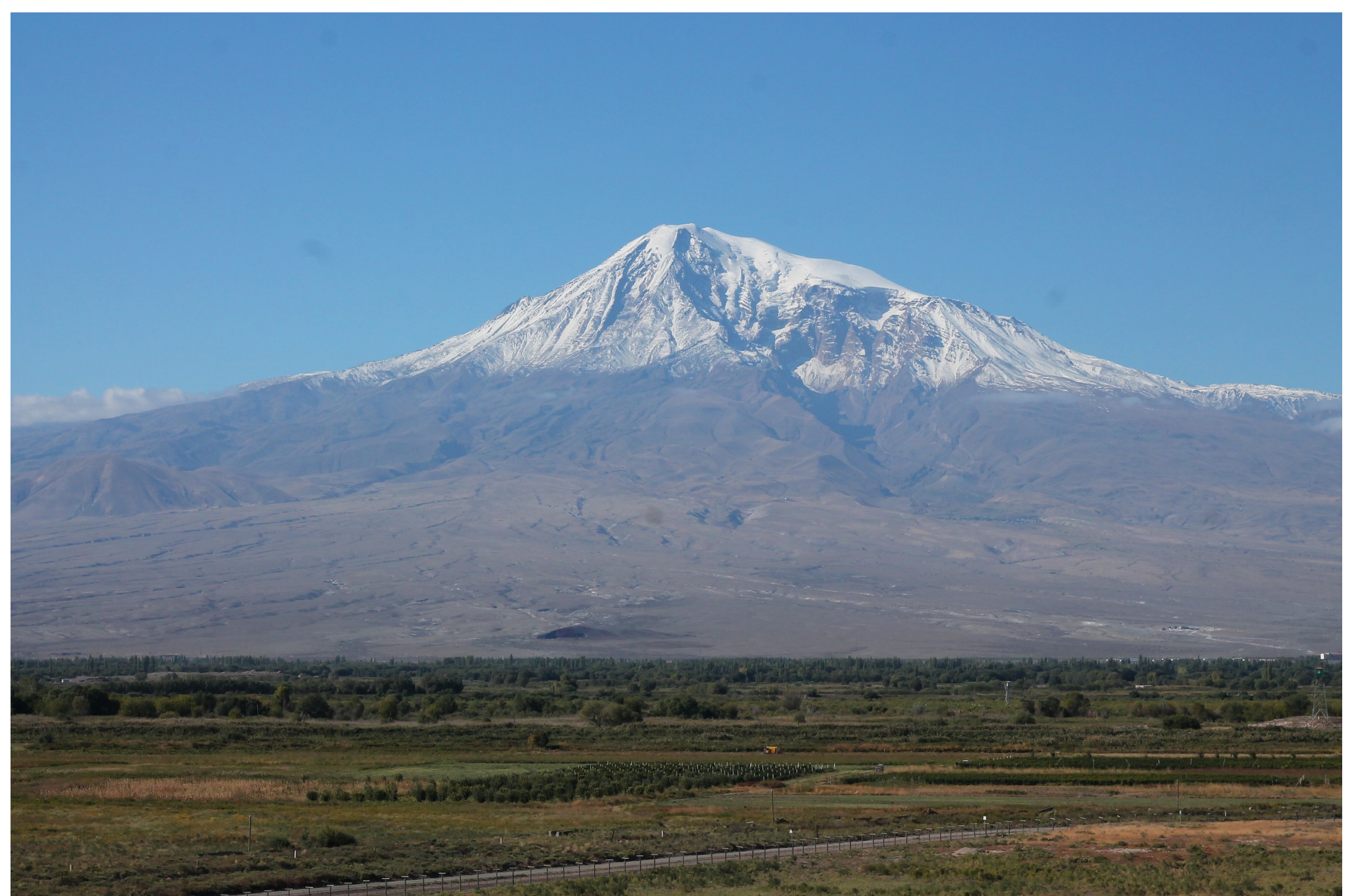

Foto 8 - Vale do rio Araks e o Monte Ararate e a turca cidade Aralik. Se de fato havia algo em comum entre os armênios, língua e religião costumam serem apontados como pilares da armenidade, parece também um fato consumado aos armênios que o cristianismo foi uma imposição do rei Dertrad III depois que Gregório, O Iluminador, foi retirado da gruta que fora seu cárcere durante 15 anos e operou o milagre de cura do rei Dertrad III. Marina T. Machado em 1² de outubro de 2016. 


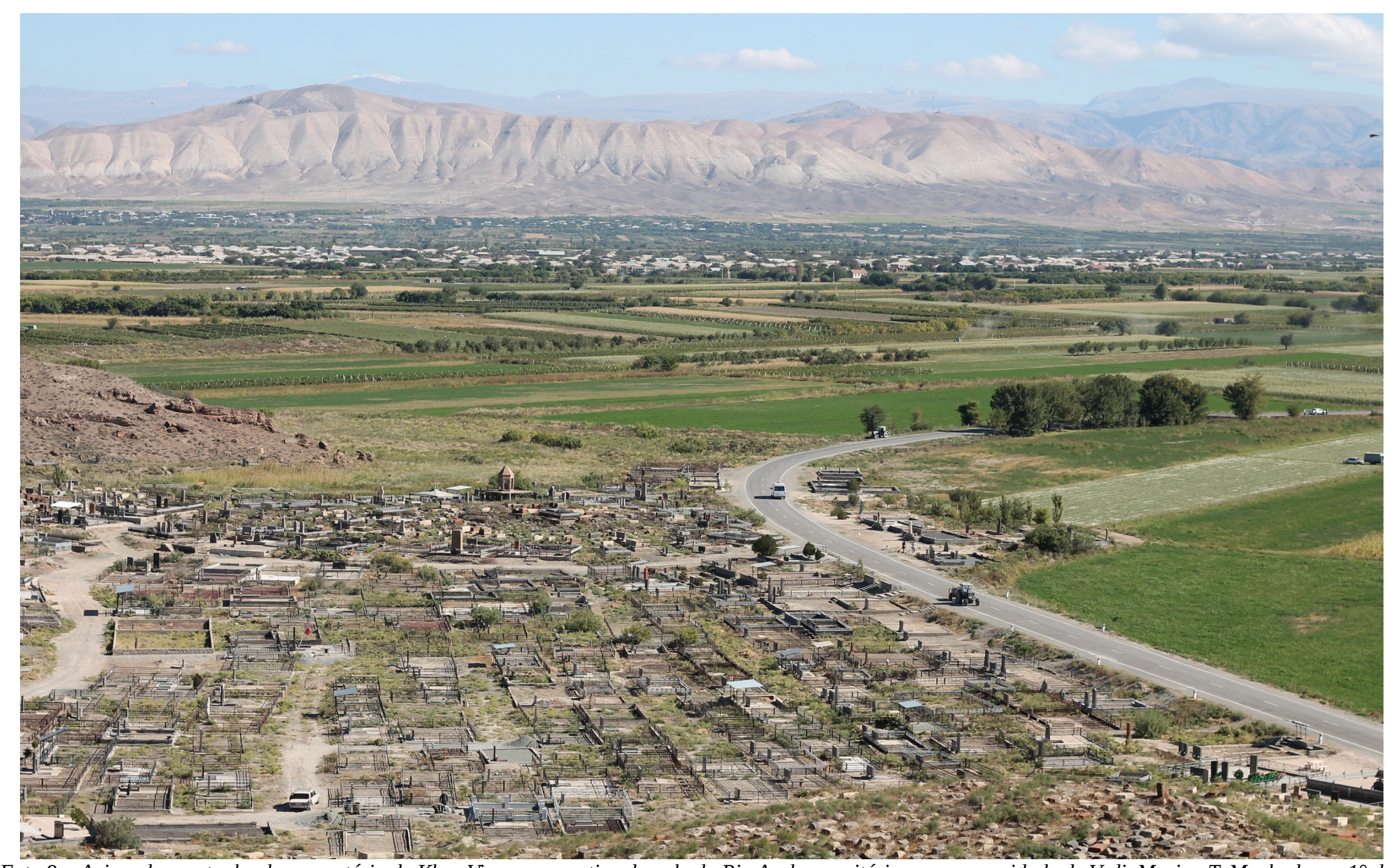

Foto 9 - Acima da montanha do monastério de Khor Virap perspectiva do vale do Rio Araks, cemitério e pequena cidade de Vedi. Marina T. Machado em $1^{\circ}$ de outubro 


\section{2) A paternidade histórica da Questão Armênia}

Parece-nos interessante traçar um paralelo entre o "momento decisivo" para o Brasil em Caio Prado Jr. (2008 [1942]: 9-13), nomeadamente, “o início do séc. XIX” e o mesmo período que também é tido como momento decisivo para a questão armênia dentro do Império Otomano, como apontam Bruneteau, Dadrian e em certa medida também a Akçam (2010). Ao autor brasileiro, além de uma internalização da Metrópole com a vinda da família real em 1808, o século XIX é evocado para salientar duas circunstâncias: o balanço final de três séculos de colonização, como uma síntese do período colonial, que, por outro lado "constitui uma chave, e chave preciosa e insubstituível para se acompanhar e interpretar o processo histórico posterior e a resultante dele, que é o Brasil de hoje” (Prado Jr. 2008:9). Assim, o período realçado, se coloca entre as heranças coloniais em sua longa liquidação do complexo colonial e a incipiente organização do trabalho livre, que para o autor na época da publicação ainda não havia se efetivado, bem como a persistência de uma "produção extensiva para o mercado exterior, e da falta de um largo mercado interno e solidamente alicerçado e organizado (ibidem:11)”. Esse é o momento da passagem, que nas palavras do autor em 1942 “não completamos ainda hoje a nossa evolução da economia colonial para a nacional (ibid.)”45.

Se Caio Prado Jr. entende o século XIX como decisivo ao Brasil por caracterizar historicamente o problema da formação nacional, os autores supracitados que abordam a questão armênia tentam delinear, por outro lado, o "nascimento” de tal questão de formação nacional nos moldes do Estado nacional dentro do Império Otomano. Para Bruneteau a questão armênia se configura como constitutiva do Oriente no último terço do século XIX e o termo “questão" para o historiador francês é uma maneira branda de designar uma situação de conflitos recorrentes entre o Estado otomano e as minorias (macedônia, grega, sérvia, albanesa ou armênia). Em um primeiro momento esses conflitos não configuravam, pelo menos no caso dos armênios, lutas de liberação nacional, mas ao final do século XIX, sobretudo a partir da criação dos partidos armênios ${ }^{46}$, a Questão Armênia passou a reivindicar a criação de um Estado armênio. O termo tornou-se bastante

45 Como visto na primeira parte essa consolidação de um mercado nacional para Oliveira (1977) ocorrerá a partir da década de 1950, momento que pode ser pensado também a partir da Giavarotti (2012) ao falar da "internalização da metrópole”.

46 Os partidos políticos armênios surgem em um contexto em que as potências europeias não conseguiram agir de acordo com suas preocupações diplomáticas em relação à questão dos armênios, o Tratado de Berlim ia de encontro com o governo hamidiano. Em 1887 cria-se o Partido Social Democrata, hintchakian, e em 1890 a Federação Revolucionária Armênia, conhecido como tashnag. Os partidos constituem o embrião de uma autodefesa frente ao subjugo hamidiano e são usados como justificação e incitamento de uma política de repressão contra o povo armênio, que adiante será classificado como potencial “traidor” (Bruneteu, 2008: 64). 
abrangente e hoje se confunde com a chamada Causa Armênia, que é relativa ao reconhecimento do genocídio de 1915.

O otomanismo do Tanzimat, para o autor francês, centralizou o poder em Constantinopla e visava promover a igualdade entre muçulmanos e não-muçulmanos dentro do Império, o que não ocorreu na medida em que a autonomia militar dada aos curdos para exercerem o jugo fiscal sobre armênios acabou por reforçar a diferenciação entre muçulmanos e não-muçulmanos. "Finalmente, cabia aos chefes religiosos manipularem a intolerância geral com fins econômicos, apelando à espoliação das terras arménias” (BRUNETEAU, 2008:63).

Lendo documentos, editoriais e livros como "História del genocídio armênio” de Vahakn Dadrian (2008), podemos notar que as primeiras ideias nacionais armênias datam da segunda metade do século XIX quando, depois do Tratado de Berlim de 1878, surgem as primeiras organizações e partidos armênios em reação ao autoritarismo e arbitrariedade sobre as minorias cristãs perpetradas durante o governo do Sultão Abdul Hamid II (1876-1908). Um famoso documento francês de 1883 é apontado por Dadrian como a origem da "Questão Armênia"47. O texto é um informe escrito pelo cônsul francês em Constantinopla na época, Paul Cambon ${ }^{48}$, e tem o flagrante título: “Exposé historique de la Question Arménienne”. No relato, Cambon afirma que os armênios encontraram melhor recepção em Londres do que em Paris para suas demandas, bem como relata falta de justiça aos gregos, albaneses e árabes. O francês entende a assim chamada “Questão” mais como uma reação do que uma provocação e aponta a Questão Armênia como uma expressão do antagonismo entre Inglaterra e Rússia, ou seja, como uma vácuo do intervencionismo das Potências na ocasião. Cambon se choca, com razão, com as declarações das autoridades otomanas que diziam que os "armênios não existiam” ou que estavam fazendo complôs e vai além ao afirmar: "La Puerta consagró un movimiento que cuenta ahora sus mártires; por su obstinación en mantener en Arménia un verdadero regimen de terror, arrestos, asesinatos, violaciones, etc.” (Dadrian, 2008: 48). Nesse sentido, as tentativas de aproximação política entre armênios especialmente com Inglaterra e Rússia, na busca de modernização e igualação de direitos, foi utilizada desde o período hamidiano (1876-1908) e aprofundada com o nacionalismo turco do Comitê União e Progresso já no século XX. O editorial do New York Tribune em 05 de dezembro de 1894 também faz alardes sobre a situação dos armênios sob o domínios do Império Otomano e indaga sobre a participação das potências supracitadas ${ }^{49}$.

47 Nesse mesmo livro há uma interessante e atual citação de Victor Hugo que diz: "Se um homem é morto em Paris, é um crime; se cortam os pescoços de 50.000 pessoas no Oriente é uma Questão”.

480 mesmo cônsul é citado por Akçam, pois segundo o historiador, Canbon relata que o então ministro das Relações Exteriores otomano admitiu que o governo participara dos massacres que posteriormente são denominados de hamidianos (Akçam, 2010: 68). 
Parece, no entando, que Taner Akçam é quem melhor faz o apanhado histórico ao longo do século XIX sobre as condições das populações não muçulmanas sob o domínio do Império Otomano. O autor demonstra as mudanças no significado do otomanismo que foram se desenrolando ao longo do século XIX, do Tanzimat (reorganização) de 1839 até o governo de Abdul Hamid II. Na perspectiva de Akçam, Abdul Hamid II, o “Sultão Vermelho” entendia o Tratado de Berlim como ingerência das potências: o Império Otomano se via forçado a promover uma política de igualdade entre as minorias, além das perdas terrritorias da guerra Russo-Turca. Frente a esta conjuntura, o "Sultão Vermelho" inverte o sinal da igualdade entre as populações de crenças diferentes nesse otomanismo da reorganização, exarcerbando, através do discurso do Estado, as diferenças entre as populações dentro do Império. A gestão hamidiana passa, então, a entender a manutenção do Império Otomano como um dever religioso pondo em prática uma gradativa política que demarcou cada vez mais as diferenças entre os súditos muçulmanos e não muçulmanos. Deste contexto formam-se representações da Europa e russas apoiando os cristãos otomanos e suas lutas nacionais em resposta às políticas de diferenciação.

Ao longo do importante e detalhado capítulo sobre "El Estado otomano y sus poblaciones no musulmanas”, Akçam aponta para as guerras entre otomanos e as potências europeias já no final do século XVIII em diante que "resultaran em tratados de paz que trajeran privilegios significativos a los súbditos cristianos otomanos, los cuales, a cambio, pavimentaron el camino para la eventual independencia de estas comunidades no musulmanas (2010: 45).” Ainda segundo esse autor, a revolta sérvia em 1804 é tida como o começo deste fenômeno a muitos autores. No entanto, sua estratégia de apresentação da “questão” não está diretamente preocupada com a "paternidade” ou com o "momento decisivo" para o surgimento da questão. Desta feita, o autor compreende mais como um longo processo histórico que é relativo à queda do Império Otomano, passando pela análise do estatuto jurídico de dhimme, que era inferior ao dos turcos, os Tratados de Edirne (1829), quando as comunidades cristãs passam a poder participar das administrações locais, o de Paris (1856) que dava às potências o direito de proteger a população cristã do Império, assim como o direito de intervir, a primeira constituição otomana de 1876 e, por fim, o Tratado de Berlim (1878) e seu famoso artigo $61^{50}$. Essas ações políticas advindas das potências européias foram seguidas de 49A Biblioteca Nacional Armênia situada em Yerevan tem um importantíssimo acervo digitalizado de editoriais de jornais europeus catalogado desde o final do século XIX, quando é possível perceber que o tema dos armênios subjugados à administração otomana tonar-se tema recorrente nos editoriais de jornais franceses, americanos e ingleses. Os materiais para consulta estão disponíveis no site da Biblioteca. Nota-se que o catálogo separou os anos dos massacres hamidianos (1894 e 1895) e também do período da guerra de 1914 e o Genocídio (1915 a 1918). http://greenstone.flib.sci.am/gsdl/cgi-bin/library.cgi?e=p-01000-00---off-0GENOCIDE100--00-1----0-10-0---0--0direct-10---4-------0-11--11-en-50---20-about---00-3-1-00-0--4--0--0-0-11-10-0utfZz-8-00\&a=d\&cl=CL5 50 Reproduzimos o que foi publicado, em espanhol, por Taner Akçam, 2010: 60: La Sublime Puerta se compromete a realizar, sin más demora, las mejorias y reformas que exigen las necesidades locales en las provinicias habitadas por armenios, y a garantizar su seguridad contra los circassianos y los kurdos. Hará conocer periódicamente las medidas 
mais pressões por reformas para "lograr autonomia”, mas o "Sultão Vermelho" se esquivou o quanto pode. O sultão tentou ainda chamar a atenção para a necessidade de incluir os curdos, como minoria que carecia de direitos, mas segundo Akçam isso não interessava aos europeus que entendiam estes últimos como "primitivos" e que, com isso, o governo queria desviar o foco das reformas, especialmente com os posteriores recuos em relação à direitos que encaminharam uma ideologia hamidiana de pan-islamismo ${ }^{51}$. Ao longo desse anos também ocorreu a reação a essa polarização fomentada pelo Estado já ao final do séc. XIX.

Os massacres direcionados às populações cristãs sofrem uma mudança de caráter depois da década de 1890, segundo o Akçam, que afirma ainda que os "muçulmanos haviam se unido em resposta aos massacres dos Bálcãs e aos assaltos das grandes potências” e que Abdul Hamid II considerava "as comunidades cristãs restantes como uma causa perdida”, dirigindo seus esforços para "uma vinculação mais estreita dos muçulmanos súditos com o trono" 52 . É nesse contexto de tensão e hostilidade que é criado, por decreto imperial em novembro de 1890, o regimento dos hamidyie:

Usando el pretexto de un incremento em la actividad de las organizaciones revolucionarias armenias, el gobierno otomano estabeleció fuerzas de caballería kurdas irregulares, los regimentos Hamidye. (...) Fueron formados com kurdos de regiones limítrofes del Cáucaso ruso, quienes habían permanecido leales a la Puerta. Aunque la historia oficial describe a estas unidades como habiendo sido constituidas para contrarrestar una merma en el personal militar y para promoveer la seguridad em la frontera rusa, un buen número de fuentes turcas afirmó que su objetivo real fueron los armenios (Akçam, 2010: 61-62).

Se até este momento as revoltas das províncias queriam mudanças sociais ou visavam independência nacional e separatismo, na última década do século XIX, a mudança de caráter é relativa ao esforço do Estado otomano "para lograr una especie de unidad nacional sobre la base de

tomadas a este efecto a las potencias, las que vigilarán su aplicación.

51 “(...) é claro que os massacres de 1894-96 foram planejados centralizadamente.

No inicio do ano de 1894 o governo de Abdul Hamid II encontrou uma "oportunidade" para dar exemplo de como seria sua postura frente a possíveis resistências. Os camponeses armênios da região de Sassoun se rejeitaram a pagar uma dupla carga de impostos cobrada de um lado pelo Estado e de outro pelas tribos curdos hamydie, apresentaram queixa formal em Istanbul alegando que o governador local incitava os muçulmanos locais contra os armênios. A revolta foi suprimida e a violência se agravou. O massacre em Sassoun vitimou entre quatro e seis mil armênios e iniciou um período de três anos (1894-96), conhecido como massacres hamidianos. Essas ações punitivas tinham um objetivo preciso de exterminar o "elemento armênio" e desencadearam uma onda de violência até então desconhecida. Ao longo desses três anos centenas de massacres se sucederam nas cidades das seis províncias orientais, onde os armênios muitas vezes eram maioria numérica. Nas palavras de Bruneteau: "Em três anos, foram contabilizados no total entre 200000 e 250000 vitimas, as quais tem que se acrescentar um milhão de pessoas saqueadas e despojadas dos seus bens e milhares de mulheres raptadas. Assim, ficaram em ruínas 2500 vilas e cidades, foram destruídas 645 igrejas, 328 transformadas em mesquitas e milhares de armênios foram islamizados á força (2008: 65)”.

Taner Akçam afirma que entre as diferentes fontes há diferentes as cifras de morte que variam entre $80.000 \mathrm{a}$ 300.000

Há uma discussão acerca da finalidade dos massacres hamidianos, se eles constituem ou não genocídio. Aqui não aprofundaremos esse debate, para isso ver Loureiro, 2013 e Almeida, 2012. Pode-se afirmar que os massacres hamidianos são um esboço para o genocídio em 1915, ou nas palavras de Bruneteau ao citar Dadrian, "prelúdio experimental”, uma vez que testaram métodos de destruição e abriram o precedente da impunidade aos massacres. 52 Idem: 61. 
una ideologia panislamista, em un intento de contener su proceso de declive y colapso.” Assim os armênios são convertidos em "bodes expiatórios” nessa "política de Estado consciente” de “exclusão social de um grupo nacional-religioso, preporandemente por um motivo religioso (e aos armênios em particular)" ${ }^{\text {53. }}$.

Para Bruneteau, o desenvolvimento social e econômico da comunidade armênia ao longo do século XIX, de certa forma, encaminhava este grupo para sua formação nacional e os massacres de 1894-96 já teriam sua justificativa a partir desse possível separatismo e serviram para reposicionar os armênios enquanto minoria subjugada a um governo muçulmano. Na versão de Akçam, ao início dos massacres que depois tomam a forma de repressão sangrenta dos massacres hamidianos, Rússia, França e Grã-Bretanha reagem e voltam a pedir por reformas em um memorando, com base em princípios do Patriarcado armênio, nas seis províncias orientais da Anatólia: Erzurum, Bitlis, Van, Sivas, Diyarbekir e Harput. Entre idas e vindas e reportes insatisfatórios especialmente aos britânicos, Abdul Hamid II tenta uma parceria sem resultados com os alemães para, em 11 de maio 1895, apresentar um pacote de reformas traçado em conjunto com as três potências. Todovia, o sultão julgou que as propostas violavam sua soberania, porém como a pressão por reformas aumentava, o próprio sultão sugeriu um pacote de reformas só aos armênios, de modo a incluí-los na polícia e gendarmeria e fazer mudanças no campo da administração, justiça e tributos. Promessas não faltavam, mas o fato é que este “assunto interno” continuaria sem resolução e para o historiador turco Taner Akçam (2010) "las diferentes intervenciones y acuerdos extranjeros tuvieron un efecto negativo, no produjeron reformas duraderas, y jugaran una parte significativa, tanto em las matanzas de 1894-96 como em el Genocidio Armenio de 1915.” Mais ainda, de acordo com o autor, mesmo com "lenguaje de intervención humanitaria, cada uno de los estados europeos estaba perseguiendo sus proprios intereses económicos y políticos”. Assim, “devido a la política hipócrita de Europa, el problema armenio continuó sin resolverse" 54 .

Outro aspecto importante a se ressaltar é a crise financeira e de arrecadação pela qual estava passando a Porta. No último quartel do século XIX a Porta declara falência do Estado e em 1881 constitui a administração da Dívida Pública ${ }^{55}$, passando a acumular impagáveis dívidas para com os bancos europeus e, para complicar ainda mais, muito longe de competir industrialmente com os grandes centros europeus. Curiosamente, alguns anos mais tarde, Lenin ${ }^{56}$ classificaria os otomanos (já como Turquia em 1916) enquanto uma semi-colônia dos capitais imperialistas. Ele apresenta dados “do economista burguês” A. Lansburgh que, embora sofram da desconfiança do autor, 
mostram um aumento de 92\%, entre 1889 e 1908, da exportação dos capitais alemães para o Estado otomano. O autor e líder da Revolução de Outubro diz que além dos empréstimos como exportação de capitais, é na aquisição de produtos fabricados pelos cartéis com esses mesmos empréstimos que se dão as “fraudulentas maquinações do capital financeiro" que assim “esfola o boi duas vezes” Guerras e perdas territoriais, dívidas enormes para com capitais estrangeiros, inflação e escassez de alimentos $^{58}$, bem como tensões de cunho racial e religioso, davam o tom da crise e eminente queda da Porta na passagem do século XIX para o século XX.

Já no início do século XX, um período de franca decadência do Império Otomano, ocorre uma das mais violentas transições de poder que se tem notícia. “O Sultão Vermelho”, Abdul Hamid II é derrubado pelo Comitê União e Progresso (CUP), cujo principal grupo político de sua composição é conhecido como “Jovens Turcos”. A Revolução Turca que data de 1908 não derruba o sultão de imediato, mas “propagam-se pela Anatólia ventos de esperança ${ }^{59 » . ~ O ~ C U P ~ a s s i n a l o u ~}$ restituir o que previa o Tratado de Berlim (1878), gerando grande empolgação entre os armênios e turcos, pois estes acreditavam que as tiranias propagadas pelo governo de Abdul Hamid II cessariam. O que ocorreu, no entanto, foi a disseminação de manifestações absolutamente violentas pautadas em discursos nacionalistas ${ }^{60}$. Quando ocorrem os massacres sobre a população armênia de Adana em 1909, a esperança de mudanças e igualdade se esvai e o partido Dashnak (Federação Revolucionária Armênia), que estava se reunindo com o CUP para tentar avançar na busca de mais liberdade política aos armênios sob domínio otomano, rompe com a gestão dos Jovens Turcos que já mostrava a radicalização de seu nacionalismo. No dia 23 de janeiro de 1913, os Jovens Turcos efetivamente tomam o poder, instaurando um triunvirato que era comandado por Talaat Paxá, ministro do Interior, Enver Paxá, ministro da Defesa e Djemal Paxá, ministro da Marinha. Esse novo comando prometia uma nova etapa para o Império que se encontrava enfraquecido e ameaçado territorialmente, após perder grande parte de sua extensão ocidental na Guerra dos Bálcãs (1912-13). Mais do que isso, o Comitê em pouco tempo retoma as políticas de assimilação forçada ao nacionalismo turco e chega a proibir, pelo artigo 4 da Lei de Associações em 16 de agosto de

57 Idem: 662.

58 Loureiro, 2013: 38.

59 Spinelli, 2011: 8

60 Para se ter uma ideia de como antes desse período as populações cristãs e muçulmanas conviviam de outras maneiras, nem sempre hostis, vale citar uma passagem do romance “Os quarenta dias de Musa Dagh” de Franz Werfel, que tematiza a boa relação entre a população turca e armênia em que há inclusive um recorte de classe no discurso (p. 178): “(...) a classe urbana altamente cultivada estava coesa com a política de Enver Paxá no que dizia respeito à questão armênia. O homem das ruas, o camponês ou o proletário, esse tinha outra opinião. Acontecia muitas vezes que um müdir (patente equivalente a um tenente) ao cavalgar por seu distrito, parava, surpreso, no meio da estrada para observar como turcos e armênios choravam juntos. Via, atordoado, como à porta de uma casa armênia os vizinhos turcos lamentavam os habitantes que, sem voltar os olhos para o antigo lar, se afastavam: 'Que Deus tenha piedade de vós!' Via também como os turcos enchiam de provisões para a viagem e lhes davam presentes dispendiosos, como cabras ou mesmo mulas.” 
1909, a formação de “organizaciones políticas sobre la base de la nacionalidad o la raza o usando el mismo nombre” (Akçam, 2010: 102). A estratégia era minar legalmente a oposição cristã e as milícias armadas armênias, gregas e búlgaras ${ }^{61}$. O nacionalismo turco logo tratou de educação como política pública - assunto tão caro à mobilização geral (Gaudemar, 1981) como veremos adiante - e ao longo dos anos pré-guerra de 1914 impôs a obrigatoriedade do ensino da língua turca e tentou supervisionar todas as escolas das minorias. O otomanismo do Tanzimat no papel tinha o intuito de promover igualdade entre os diferentes povos sob o domínio do Império, já o otomanismo idealizado e praticado através da doutrina do CUP permitia igualdade somente aos turcos e turquificados ${ }^{62}$.

Em meio à guerra de 1914, com o CUP consolidado no poder, inciam-se as práticas planejadas para dar cabo ao Genocídio Armênio, visando a nacionalização da econômia e a homogenização de um pretendido território turco. Nesse sentido, o histórico discurso de Lorde James Bryce proferido no dia 6 de outubro de 1915 ante a Câmara de Londres aponta para a forma que o massacre foi conduzido com fins de "homogeinizar" o território da Porta como um território turco:

Não havia em jogo exaltação muçulmana contra os cristãos armênios. Tudo foi feito pela vontade do governo e não por considerações de fanatismo religioso, mas simplesmente porque desejavam, por razões puramente políticas, desfazer-se de um elemento não muçulmano que contrariava a homogeneidade do império e constituía um elemento que não poderia sempre sujeitar-se à opressão. (BRYCE, 2003, p. 18)

Como vimos já no período do governo de Abdul Hamid II, desde aquela época o Estado fora protagonista para efetivar uma política de diferenciação entre a população do Império Otomano, de modo a demarcar fortemente o pertencimento religioso da população que habitava o Império.A tentativa de compreensão das etnias e a criação de suas respectivas teorias se deu especialmente no período que Hobsbawm entende como “eras dos impérios (1875-1914)”, com o expansionismo imperialista dos países europeus. O “apogeu do nacionalismo”, que vai do fim da Primeira Guerra Mundial e das primeiras conseqüências da Revolução Russa até 1950, foi acompanhado também por justificações pseudo-científicas como darwinismo social, racismo científico, eugenia e seus lamentáveis fins. Tal contexto histórico se faz importante para compreender os destinos dos grupos étnicos minoritários, como os armênios e outras minorias dentro do Império Otomano. A partir

61 Akçam, 2010: 102: El 14 de septiembre se dictó una ley temporal para estabelcer una unidad militar especial com el objeto de desarmar a las milicias armenias, griegas y búlgaras.

62 Idem: 103: Estas políticas, implementadas bajo el título de un “otomanismo” que se proponía conseguir una “unión de los pueblos” (Itthad-i anasir), fueron un esfuerzo por homogeinizar culturalmente a la población alrededor de la identidad islámica-turca. 
Primeira Guerra (1914-1918), o mapa do Velho continente fora redesenhado ${ }^{63}$, em particulares formas de expressão do nacionalismo.

A noção de nacionalismo territorial, em que os Estados nacionais em formação justificam teoricamente a necessidade de um Estado homogêneo do ponto de vista étnico-linguístico, ou por meio de outros critérios que aparecem como culturais, coloca-se, no caso do Estado turco, como legitimação de um discurso que também fora proferido na invenção de outros Estados europeus durante o século XIX ${ }^{64}$. A ideia de identidade turca ou, em um momento anterior, identidade com o Islã foi usada como pretexto para a diferenciação em relação às minorias cristãs em um momento de fragmentação do Império Otomano ${ }^{65}$. Os armênios são tidos como traidores dessa noção do panislamismo que vinha desde a ascensão de Abdul Hamid $\mathrm{II}^{66}$. Mais tarde, a polarização entre turquismo governante e minorias recrudece ainda mais e por meio de documentos relativos às reuniões do Ittihad ve Terakki (Comitê União e Progresso - CUP), e de declarações macabras do famigerado Dr. Nazim, se deflagra as interpretações ideológicas e genocidas acerca das ações armênias como traição ao Islã ou como "estratégia covarde” ao chamar a atenção em busca de intervenções das potências. Há nesse momento, portanto, uma disputa ideológica na formação de Estados nacionais em que a "homogeneidade" pauta os argumentos tanto aos cristãos quanto aos muçulmanos. O nacionalismo turco, forjado no século XX pelo CUP, tem profunda ligação com o darwinismo social tão em voga no positivismo europeu.

63 A implicação lógica de tentar criar um continente corretamente dividido em Estados territoriais coerentes, cada um habitado por uma população homogênea, separada étnica e linguisticamente, era a expulsão maciça ou a exterminação de minorias. Isso foi, e é, o criminoso reductio ad absurdum do nacionalismo na sua versão territorial, se bem que não tenha sido completamente demonstrado até 1940. Entretanto, a extinção em massa e até o genocídio começaram a surgir nas margens meridionais da Europa durante e depois da Primeira Guerra Mundial, quando os turcos levaram a cabo a eliminação em massa de armênios em 1915 (...) (HOBSBAWN, 1990: 161).

64 HOBSBAWN, 1990.

65 Akçam ao final do capítulo sobre as populações não muçulmanas subjugadas pelo Império Otomano em algumas passagens demonstra como essa identificação e diferenciação foi ganhando um aspecto de política oficial. 66 BRUNETEAU, 2008. 


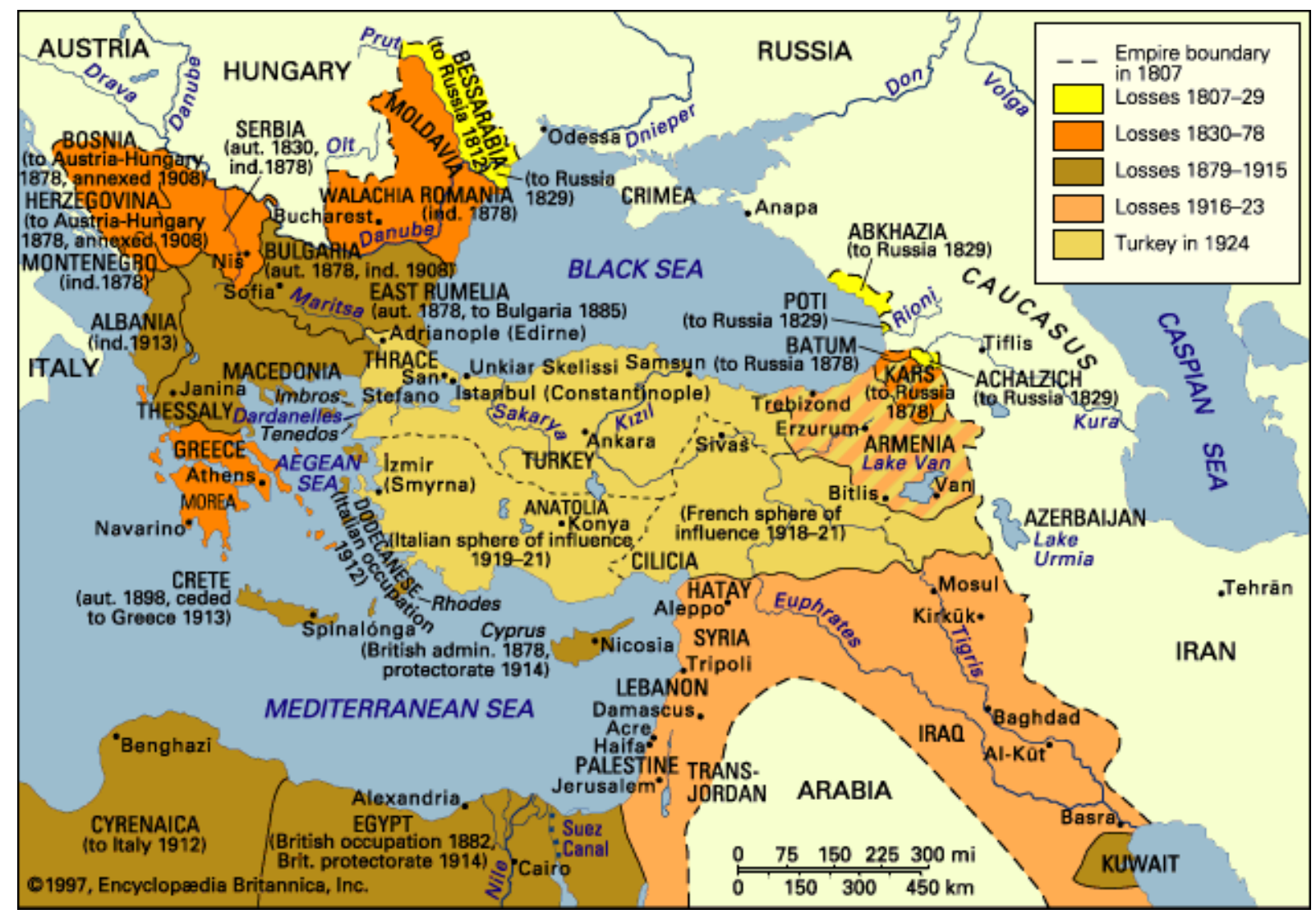

Mapa 1 - Declínio do Império Otomano. Enciclopédia Britânica, 1997.

A Porta, fora um Império territorial multiétnico diante de uma eminente fragmentação e que, nessas condições, teve como imposição da gestão de seu território a forma do nacionalismo territorial, sua via modernizadora diante da crise. Por esta via, se não a acumulação por extermínio ao menos a centralização de capitais através do extermínio teve grande importância na formação de uma Turquia homogênea aos moldes kemalistas depois da guerra de 1914. De outro lado, os armênios não chegaram a elaborar politicamente uma organização para criar um Estado nacional a ponto de travar uma guerra de liberação nacional. Estiveram sim, envolvidos em reações a massacres que vinham desde o final do século XIX que tinham por intuito formar a "Turquia para os turcos”. Exemplos mais conhecido como o daqueles armênios da banda oriental que se juntaram aos russos na humilhante derrota do exército turco em Sarikamis durante a guerra de 1914, ou ainda, alguns grupos que resistiram, como por exemplo, em Urfa, Zeitun, Van e o famoso caso de Musa Dagh, tematizada na entrevista com Hampartsum Moumdjian na primeira parte do texto.

Se o século XIX representa o “momento decisivo” para a formação dos Estados nacionais e dissolução de impérios, o início do século XX vai unir processos não-simultâneos de acumulação e, como refugiados de massacres no meio de uma guerra que fundou a mobilização geral, os armênios 
vão chegar ao Brasil e a outras partes do mundo mobilizados pelo trabalho, capital e terra. A assim chamada diáspora armênia que se desdobra desse momento histórico é expressão dessa trama de relações capitalistas que aparece como relações culturais. 


\section{3) Yerevan, 22 de setembro de 2016}

Nesta quinta-feira (hingshabti) vim para a escola AYB e, na sala dos professores, tive uma conversa com um deles sobre as famosas avós armênias em território turco, capturadas quando crianças por famílias turcas e curdas. Art'ak, um dos docentes de história da escola, contou-me a história de um homem que soube tardiamente que sua avó era armênia da região de Van e que depois disso foi atrás de suas raízes, visitou Yerevan e outros lugares. Eles, Art’ak e o homem, se conheceram quando o professor foi ao mercado em uma cidade próxima à Mush. Na primeira ida ao mercado, uma compra apenas, mas no retorno à banca daquele turco-armênio, que havia vendido algumas comidas ao professor, o comerciante iniciou uma conversa mais profunda chegando a dizer ao professor que via nele um armênio por causa dos seus olhos. Curiosamente, entre as características sempre ressaltadas do assim chamado olho armênio, isto é, o tamanho grande e o olhar triste, não pareceram a mim tão marcantes no par de redondos mirantes de íris negra do professor. Depois foram à casa do comerciante para um café e assim tornaram-se amigos. O comerciante então visitou Yerevan e Echimiazian, converteu-se ao cristianismo armênio e seguiu na busca de suas origens familiares agora com a ajuda de Art'ak e, depois de certo tempo eles conseguiram encontrar os descendentes de seus velhos parentes. Art'ak denomina essas pessoas que foram turquificadas e, por que não dizer que em alguns casos curdificadas, de "krypto armenians ${ }^{67}$ ”. Comentei sobre minha vontade de conhecer a Cilícia (Kilikia) e sobre os perigos atuais devido à fronteira síria e os conflitos entre o governo Erdogan e as milícias curdas. Ele concordou, mas acrescentou que os turcos respeitam muito os turistas estrangeiros que levam dólares ao país. A Turquia é o terceiro país que mais recebe turistas no mundo.

Os dois novos amigos então visitaram diversos lugares da chamada Armênia histórica. O professor mostrou-me fotos de construções na Turquia e vilas curdas em que é possível notar pedras tuf e/ou fragmentos de khach kars (pedras cruzes) nas paredes das casas, como muitas das fotografias de meu primo distante Norair Chahanian em "O poder do vazio” ${ }^{68}$. Mostrou-me também a impressionante Ani e suas igrejas destroçadas, embasbaquei-me com a yekeghetsi (igreja) cortada, literalmente, ao meio por um raio. Diz a lenda que Ani foi a capital da Armênia histórica sob a batuta do rei Ashot III no ano 961 a.C. que transferiu a capital de seu reino de Kars para a vizinha cidade a 45 quilômetros, cidade essa que parece ser hoje um museu a céu aberto dentro do território

67 “Armênios da cripta”, expressão para denominar o subjugo dos armênios que passam a ser identificados com seus opressores e que têm sua história familiar escondida ou apagada. Há muitíssima gente de origem armênia, na maioria dos casos mulheres, que foram incorporadas à famílias muçulmanas e mantidas em antigos territórios otomanos, atualmente Turquia.

68 CHAHINIAN, 2015. Para o assunto de Igrejas destruídas em território turco conferir o artigo “Genocide after genocide” de Karapetyan S. G. Disponível em http://www.fundamentalarmenology.am/datas/pdfs/90.pdf 
turco daquele período que os armênios entendem como um dos momentos mais prósperos e importantes para a construção da armenidade. Enfim, mais um lugar na lista para ser visitado. A essa altura acho que já tenho um olho treinado para distinguir a típica arquitetura armênia.

Sobre a polêmica se Mesrob Mashdots também foi o criador do alfabeto georgiano Art'ak disse que o alfabeto foi mudado três vezes, mas que a primeira versão se assemelha bastante ao alfabeto armênio e por isso a hipótese de que Mashdots também foi responsável pela organização das letras da Geórgia. Até aqui parece ser a melhor hipótese.

[O trecho seguinte foi escrito no mesmo dia e dialoga com relatos de Gyumri, ocorridos em agosto e que aqui estão expostos adiante embora temporalmente tenham ocorrido antes do que este relato escrito em Yerevan em 22 de setembro]

Na hora do almoço conversei com Vahran, professor de Geografia que tem me acompanhado, tendo perguntas geográficas na cabeça. Como é a distribuição da propriedade da terra, qual setor emprega mais, o que se produz no campo? Baseado nas minhas observações especialmente na região central e norte da Armênia foi possível perceber que as maiores propriedades estão voltadas para o cultivo de feno que, depois de colhido, é transformado em blocos e transportado por velhos caminhões aos mercados. Vahram disse-me que as grandes propriedades aqui tem seus latifundiários, mas que não são grandes o suficiente para necessitar e para bancar colheitadeiras gigantes e mais modernas. As pequenas propriedades parecem ser as principais produtoras de mirk (fruta) as vimos também por quilômetros à beira da estrada de ferro chegando em Yerevan, vindo de Gyumri. Um comentário interessante foi dito sobre a diferença entre a agricultura soviética e a capitalista. A primeira, de acordo com o professor de Geografia, foi responsável pelo alargamento da área cultivável do país, drenando pântanos e retirando as pedras em excesso no solo em determinadas áreas, principalmente no vale (dasht) Araratzian (as duas primeiras fotos desta segunda parte mostram esse vale). Para Vahran, a Armênia é a terra das pedras, sempre que se prepara o solo a um cultivo inicia-se retirando as pedras. A União Soviética também retirou bastante água subterrânea, o que resultou em uma salinização do solo. O território armênio nas áreas montanhosas é composto por um solo de origem vulcânica, o que faz dele fértil, porém pedregoso. Basalto, Limestone e Tuffa são as rochas mais comuns de serem encontradas por essas bandas. As áreas pouco férteis pertencem ao Estado, segundo nosso informante. O fato de não se utilizarem agrotóxicos nas produções de alimentos da Armênia gera a pergunta-hipótese sobre a agricultura entendida como orgânica ter a ver com os altos custos de insumos agrícolas que já no 
final da URSS eram escassos. Quanto aos empregos, ao que parece o principal mercado de trabalho e em ascensão é o de Tecnologia da Informação, pois possui os melhores salários, podendo chegar a US\$ 2.000. O salário mínimo hoje na Armênia está em 60.000 drams, que equivale a uns US\$ 120. Um aluguel no periférico bairro “Bangladesh” da capital sai por mais ou menos US\$ 150 para uma casa de 2 a 3 dormitórios. No centro ou no bairro de Arabkir boa parte começa a partir de US\$ 200. Aqui, como no Brasil, com um salário mínimo não se paga aluguel em grande cidade, a renda tem que ser composta por várias pessoas para que se possa ter condições razoáveis de moradia.

Outro ponto interessante abordado na conversa foi a imigração temporária/pendular dos armênios para a Rússia ${ }^{69}$. Vahran disse-me que os armênios fazem de tudo, construção, panificação, o que vier e a remuneração não raro é inferior à dos russos, restando, portanto, os dirty jobs, como adiante também será observado em relação ao imigrantes que partem de Gyumri. São nesses momentos que Gyumri torna-se uma cidade de maioria feminina, quando os homens vão atrás de algo para trabalhar na Rússia. Nesta última cidade o fenômeno é bastante mais intenso do que na capital, pois desde o colapso e o terrível terremoto do final dos oitenta a segunda maior cidade armênia peleja para ter uma situação econômica mais estável e a dependência reificada em relação à produção de mercadorias da indústria russa segue enorme. O colapso arrebentou com suas exRepúblicas e na Armênia, que é o caso que estamos em contato, persiste uma profunda ligação, influência e dependência, mas não em sentido dualista como se só os russos fossem capitalistas e as ex-Repúblicas um “outro” passível de nova rodada de acumulação primitiva. Não, talvez mais próximo à ideia de “oásis e desertos” da rentabilidade que nos faz pensar nas guerras de ordenamento mundial, migração e barbárie

\begin{abstract}
nos limites históricos do moderno sistema produtor de mercadorias. A migração global não pode mais tornar-se um movimento de emancipação na base do trabalho assalariado e da produção de mercadorias, porque já é consequência de uma desmobilização global de força de trabalho. O fato de uma parte cada vez maior da humanidade se encontrar em fuga já é, propriamente, uma expressão de que o sistema mundial de trabalho assalariado de produção de mercadorias está desabando e não pode mais ser politicamente regulado.

A luta necessária contra a discriminação não pode ser estabilizada no sentido do mero reconhecimento enquanto sujeitos da produção de mercadorias. Se as migrantes e os migrantes não quiserem outra coisa senão ganhar o seu pão pela valorização do capital, o seu barco só poderá ir a pique. O movimento das migrantes e dos migrantes não pode ser um novo movimento operário que não queira outra coisa senão o reconhecimento de seus interesses na ordem existente. Pelo contrário, também estão caindo fora do reconhecimento, total ou parcialmente, partes nãomigrantes da população "supérflua" (Kurz, 2005).
\end{abstract}

69 Na contramão histórica estão os movimentos migratórios de armênios ou descendentes à Armênia Soviética que, segundo Grigorian, podem ser divididos em três momentos de "repatriação": 1921-1939 contando com 42.000; 19461949 contando com 90.000 e entre 1962-1982, período com a menor das cifras 32.000. Esses dados foram-me apresentados pela professora Deize Crespim Pereira do DLO-FFLCH-USP em uma apresentação sobre a Armênia Soviética ocorrida na FFLCH-USP em 25 de maio de 2017.

Cf.: Grigorian, 1995. 
Aí residem questões interessantes. Foi a URSS e seu desastroso estatismo de sua economia de guerra uma espécie de imperialismo negativo ${ }^{70}$ A Rússia nos vorazes processos de reorganização de capitais nos anos que se desdobraram na década de 1990 aos poucos reafirmou, em outros termos é verdade, sua influência no Cáucaso e segue despejando sem dificuldades suas mercadorias nas prateleiras dos mercados armênios, bem como na venda de armas a azeris e armênios desde que o conflito Nagorno-Karabakh começou.

70 Há uma excelente passagem sobre esse problema em “O colapso da modernização”, de Robert Kurz, especificamente o item do terceiro capítulo entitulado “a qualidade capitalista da 'acumulação primitiva socialista', em que o autor alemão traz as declarações de Stálin sobre as possibilidades, morais inclusive, da União Soviética promover sua "acumulação interna de mais-valia" e a monetarização de seu território, mesmo sofrendo com embargos bancários dos países ocidentais e com o dilema da expansão colonial imperialista. Cf.: Kurz, 1992: 58-62, bem como item "a extinção da dinâmica capitalista no socialismo real” (páginas 83-90) que faz parte do capítulo seguinte e será tematizado neste estudo no item “da modernização retardatária ao pulo do sapo”. 


\section{4) O boom de 1914}

A guerra de 1914 é usualmente representada como uma disputa colonial entre as potências europeias consolidadas, França e Inglaterra, e as potências emergentes recém-unificadas, Alemanha e a Itália, que entra tardia no conflito. De fato, havia uma disputa dos mercados coloniais e seus recursos, atrelado a isso uma busca pelo domínio capitalista pautado na capacidade industrial. O que resultou disso foi uma sucessão de catástrofes sociais que inauguraram o século XX:

Na época das duas guerras mundiais industrializadas e da crise económica mundial do período entre elas e a elas ligado, os Estados-nações capitalistas europeus predadores digladiaram-se e saíram mortalmente esgotados do campo de batalha. O mercado mundial entrou em colapso; o comércio mundial recuou para um nível só comparável ao dos finais do século XIX. Surgiu com isso o perigo de se impedir a continuação do desenvolvimento capitalista nos mercados internos das economias nacionais e dos Estados fechados sobre si próprios. (KURZ, 2003: 9)

O que se viu posteriormente foi a passagem do poderio político-militar policêntrico para a disputa bipolar que caracterizou a Guerra Fria e em seguida à "Pax Americana”, quando os EUA tornaram-se a potência hegemônica que nunca se desgarrou do desenvolvimento armamentista, aliando sua presença militar global, a “economia de guerra permanente”, à manutenção de sua reprodução como centro capitalista inalcançável (KURZ, 2003).

$\mathrm{Na}$ época do antigo imperialismo policêntrico das potências industriais europeias (aproximadamente entre 1870 e 1945) tratava-se sobretudo da repartição territorial do mundo em colónias nacionais e "zonas de influência". Deste nacional-imperialismo europeu clássico estava enraizado no princípio territorial do Estado nacional burguês, tal como ele se tinha constituído em oposição ao princípio dinástico ou pessoal da sociedade agrária feudal. A expansão territorial dos Estados nacionais capitalistas, já iniciada no começo da Idade Moderna, prossegue em larga escala com base na industrialização; o seu objectivo era o alargamento do controlo territorial. Não era ainda um mercado mundial sem fronteiras que estava na base desta evolução, nem uma globalização transnacional do capital, mas, precisamente ao contrário, a formação do processo de acumulação, crescentemente baseada na economia estatal e nacionalmente centrada. A expansão do movimento económico assumiu por isso a forma de um esforço pela simples constituição de parciais e relativas "economias mundiais" (na pluralidade das nações), controladas pelos "grandes impérios" nacionais. (KURZ, 2003: 20) 71 $^{1}$

Essa discussão sobre o imperialismo é de grande influência nesse campo de debate histórico do final do século XIX e início do século XX. Esse período que representa o fim da era dos impérios territoriais com a fragmentação em Estados nacionais é momento em que se dá o entrelaçamento do capital financeiro com a produção de valor e que vai ressignificar essas novas fronteiras e relações territoriais da economia mundializada. $\mathrm{O}$ ensaio popular de Lenin “Imperialismo, fase superior do capitalismo”, um dos textos mais influentes do século XX, constitui

71 Em Kurz (2003) está exposto muito amplamente um macro argumento histórico e a ele escapam muitos eventos e processos, o desmembramento do Império Otomano e suas consequências, como o Genocídio Armênio, são um exemplo dessa redução. 
um interessante estudo de época, escrito em 1916, em meio ao turbilhão dos acontecimentos da guerra de 1914 e pouco antes da Revolução Russa, na qual a República Armênia se integrará ao final de 1920. Este foi um período de disputas teórico e práticas no qual Lenin fez suas críticas à esfera financeira. Para o autor, essa esfera financeira imperialista abre fronteiras na guerra, isto é, pacifica territórios e os incorpora à sua esfera de influência, em busca de mobilizar trabalho produtivo capaz de acumular e pagar juros. A centralização da produção e de capitais monopolistas para Lenin vai consolidar os cartéis e trusts no início do século XX e assim "o capitalismo transformou-se em imperialismo”, pois a internacionalização é uma necessidade da valorização do valor. Há nesse processo histórico o entendimento de que o imperialismo se constitui na guerra, na conquista de novos mercados quando da crise de superprodução em 1900 e a consequente exportação de capitais e maquinaria.

Expansão do capital é crise ou crise do capitalismo se desafoga com expansão de mercados? Essas são perguntas transversais deste estudo ${ }^{72}$. Essa pergunta se requalifica no momento do colapso da U.R.S.S. e as imposições concorrenciais oriundas da terceira revolução industrial. Tal discussão terá breve desdobramento no relato que trata da visita à cidade de Shushi.

Para Kurz (2003), Lenin entende o imperialismo “essencialmente como política de anexação territorial”, o que para o autor alemão "sua caracterização do imperialismo como política nacional policêntrica de anexação é largamente correspondente às formas reais do desenvolvimento capitalista mundial de então"73. Desta monta parece que para Lenin o imperialismo não se reduz unicamente expansão territorial, mas refere-se principalmente à dinamização da relação capitalista.

A guerra, problema político entrelaçado com a realização da produção e valorização do valor, “é a política por outros meios”, como bem dito pela máxima de Foucault. Contudo, na “lei geral de acumulação capitalista”, Marx já havia desdobrado a ideia de que força de trabalho reordenada pela guerra e política constitui em larga escala o problema da gestão da população para

72 Neste ponto há um grande debate entre as ideias de Lênin e as de Rosa Luxemburgo sobre a acumulação de capital. Aqui não teremos fôlego para dar conta desse debate, optamos por expor brevemente o ensaio de Lênin pensado pela sua forte influência, inclusive nos debates da Geografia.

73 Vale ressaltar também a influência das ideias de Lenin nas teorias sobre dependência, sobre a "não simultaneidade" nos termos de Robert Kurz, em outras palavras, que o imperialismo estava abocanhando áreas de produção "nãocapitalista” - e nesse caso específico há um grande debate em que o sociólogo José de Souza Martins se destaca, pois produziu bastante ao pensar as relações de produção do campo brasileiro - em busca de outros “oásis” de acumulação primitiva. A perspectiva adotada aqui parte da ideia de que - embora históricamente seja possível observar diferentes níveis de capacidade produtiva ao longo da história da modernidade capitalista em seus diferentes lugares, regiões ou países - a moderna sociedade produtora de mercadorias já impunha seu sentido de valorização do valor, o fim-em-si do dinheiro mesmo no Brasil enquanto colônia portuguesa. Caio Prado Júnior corrobora com esta ideia ao pensar que o sentido da colonização estava voltado à produção de mercadorias tropicais para exportação e consumo nos mercados europeus, entrelaçando trabalho escravo na colônia e consumo de mercadorias por parte dos trabalhadores livres do centro capitalista da Europa Ocidental. Desta forma, ainda com descompassos em relação ao nível médio de produtividade, a relação-capital há muito tempo é mundial e não há, portanto, a dualidade “capitalista” e “nãocapitalista”. 
o capital e o Estado. Para Lenin o desenvolvimento desigual pode desdobrar em guerra e é o locus do capital que busca expansão ${ }^{74}$.

Na expansão crítica pela via da guerra é que se pacificam fronteiras com bombas, controlam-se populações e o mercado flui como território do capital. Os lucros de monopólios, juros de monopólio e renda monopolista a fazer todo o gerenciamento que coincide entre bancos e empresas. Nesse movimento de tendência à concentração parece óbvio, no entanto, que o jogo pode ter mais um contralance de novos arranjos a partir de investimentos oriundos de capitais ociosos, de outras rendas de monopólio que carecem de rotação mais rápida. Novamente percebe-se o quanto controle e centralização (cap. 23, Tomo II, Livro Primeiro d'O capital de Marx) estão articulados com os capitais se expandindo e se reproduzindo além dos países ricos, na periferia do capital. Lenin foi muito hábil ao expor como determinados bancos têm mais poder e controle sobre determinados territórios do que os próprios Estados, na medida que a liquidez dessas relações é dada por esses capitais bancários. Mas o argumento vai além ao expor também que os grandes bancos aos poucos vão centralizando operações em volumes cada vez maiores de modo que mesmo os bancos menores, quando não vão à bancarrota, têm seus capitais subordinados ao capital dos grandes bancos. Tal processo nos coloca a pergunta sobre como os excedentes de capitais mobilizam a terra e suas rendas e as pessoas, reificadas enquanto força de trabalho, a intensificar a urbanização como padrão da sociedade pacificada consumidora de mercadorias e crédito. Na colônia, pacificada para isto, e sua exportação que almeja a produção ampliada de valor, há estreita relação entre monopólio bancário e industrial através do capital financeiro.

A partir do momento histórico da guerra de 1914, se intensifica a reprodução do capital financeiro que ganha ares de reprodução social ampliada e ficcionalizada do capital mundializado, transformando D-D’ sem produzir valor. Nesse momento a economia mundial consolida a ideia da competição pela alíquota da mais-valia global para sobrevivência concorrencial entre os capitais privados ou em cartéis e trustes. Robert Kurz (2003), entretanto, percebe que a interpretação de Lenin é fruto de seu tempo - diferente do tempo atual das “guerras de ordenamento mundial” - e que, por isso, "não via sob o aspecto de uma crise categorial das formas económicas, mas sobretudo como a queda da constelação até então em vigor do capitalismo mundial”.

74 A interpretação de Kurz (2003) realça que a expansão sobre territórios da Eurásia foi uma necessidade da Revolução de Outubro em sua 'modernização recuperadora': “O primeiro passo deste movimento de descolonização e de "modernização recuperadora", que atravessou todo o século XX, foi dado imediatamente a seguir à Primeira Guerra Mundial pela Revolução de Outubro na Rússia, sem dúvida a Revolução Francesa do Leste. É verdade que o Império dos czares fazia parte das potências europeias tradicionais e tinha ele próprio roubado um império colonial para si, embora não no Ultramar, mas como expansão para a massa continental da Eurásia. Mas, ao mesmo tempo, a Rússia era ela mesma também periferia, sem uma base industrial própria e, em muitos aspectos, estava em larga medida estruturalmente aparentada com as regiões coloniais e dependentes. Lenine viu a Revolução Russa sempre no duplo contexto de revolução colonial anti-europeia, por um lado, e, por outro, de "modernização recuperadora", como consciente "aprender com a Europa Ocidental". 
Robert Kurz (1997b) já havia feito outro importante contraponto às concepções de Lenin em "Pós-imperialismo”, aliando crítica teórica com os desdobramentos históricos do capitalismo ${ }^{75}$. Essa crítica de Kurz é de grande interesse ao nosso argumento e dá conta de diferenciar o fenômeno político do imperialismo do início do século XX para o seu final e início do século XXI. Se antes o fenômeno se caracterizava pela economia de guerra e pela mobilização geral, nos tempos recentes Kurz percebe a empresa transnacional flexível em crise de acumulação a substituir trabalho abstrato por inovações tecnológicas. Hoje tal fenômeno se demonstra frágil e cada dia mais suscetível aos abalos do capital fictício. O fenômeno político do imperialismo é completamente outro na guerra pelo mercado entre as empresas transnacionais, que querem influir através da flexibilidade, mas correm para longe do "gerir” territórios. Nesse contexto, Estado nacional colapsado pela situação de dissolução da economia interna também quer fugir das “áreas de influência e domínio imperial” e “o que eram vantagens fundamentais numa posição de supremacia mundial, a saber, o aproveitamento garantido de determinada capacitações da força de trabalho, matérias-primas e mercados consumidores, agora são desvantagens.” Tornar-se fixo é uma desvantagem, pois “o que hoje pode ser a vantagem de uma determinada região, amanhã pode se converter em desvantagem, e mesmo porque podem se abrir possibilidades mais atrativas em matéria de custo em outra região do mundo” de tal maneira que "os investimentos precisam ser fluidos, flexíveis e facilmente desviáveis e devem, ademais concorrer pelos melhores juros nos mercados financeiros globais”. A presença deve ser global e, ao mesmo tempo, a capacidade de retirada de regiões desinteressantes imediata e "sob essas condições, um império nacional ou multinacional parece algo antediluviano, seus custos de financiamento ultrapassam em muito seus rendimentos e ameaçam a se tornar ruinosos” (Kurz, 1994: 70).

Se Lenin mostrava Cecil Rhodes concernido quanto à fome como um problema do imperialismo, o que se vê nos dias atuais é a barbárie como produto da retirada estratégica dos capitais de localidades que não apresentam chance de remunerar juros. Pelo visto até o imperialismo perdeu sua "humanidade".

75 A oposição teórica à ideia de que o capitalismo sempre renova processos de acumulação primitiva, que é presente nas formulações de Kurz 1994 e 2003, será adiante confrontada por meio de outras entradas na temática. Tais críticas partem da reflexão acerca da realização da acumulação de capitais nos dias atuais, ou ainda, desde a terceira revolução industrial referente à microeletrônica na década de 1970. Desde esse período vem ocorrendo uma inversão da capacidade produtiva que a cada dia emprega mais tecnologia e menos trabalho humano abstrato; o problema da queda tendencial da taxa de lucro, como pretendemos discutir mais à frente com Roswitha Scholz (2016). 


\section{5) Mobilização geral e extermínio como acumulação de capital na formação nacional da Turquia}

“O Estado pela sua constituição e postura, ele deve adaptar-se às forças mágicas, que precisa mobilizar em tempos de guerra, e mostrar-se digno delas”

Walter Benjamin

O Império Otomano através da gestão militar do Comitê União Progresso (os unionistas) fez valer do monopólio da violência, e mais do que expropriar, exterminou os armênios e outras minorias não muçulmanas. "Não esqueçamos que as deportações de 1915 também representam uma expropriação em escala enorme, resultando numa autêntica “'nacionalização’ da economia” (BRUNETEAU, 2008: 80). A terra que era ocupada por armênios seria territorializada pelo capital turco nas suas pretensões de Estado nacional ao início da guerra de 1914. Os vazios (desapropriações) foram "repovoados" por turcos étnicos e curdos de confissão muçulmana (GRÜN, 1992: 16). Akçam vai além e refuta a mentirosa ideia de que o governo liderado pelos unionistas estava a fazer deportações como operação ou medida temporal de guerra: “(...) em algumas regiões, foram deportados todos os cristãos e as vezes inclusos os muçulmanos não turcos, a política de assentamento reforça a tese de que os unionistas aplicaram uma bem formulada política demográfica destinada a homogenização e turquificação da região” (AKÇAM, 2010: 250) ${ }^{76}$.

O historiador turco Taner Akçam (2010) aprofundou muito a compreensão de como se deram as operações de expropriação armênia e repovoamento muçulmano, ele entende que a questão da propriedade armênia evidencia as intenções genocidas das autoridades otomanas. O autor analise as comunicações telegráficas entre Ministério do Interior ${ }^{77}$, da Defesa, Exército, administrações locais e a Organização Especial, chefiada pelo civil Bahaettin Shakir, e que foi criada para a execução do plano do Genocídio Armênio. O historiador conseguiu demonstrar inclusive que Talaat, ministro do Interior, ludibriou as potências e seus embaixadores dentro da Anatólia ao expedir pedidos de cancelamento que eram desconsiderados após os primeiros pedidos de deportação para reassentamento dos armênios. Havia a promessa de Talaat relativa ao ressarcimento, ou ainda "que o governo proporcionaria, aos deportados, terra, suprimentos,

76 Sobre a crise balcânica já no século XX, com a perda dos territórios otomanos em 1912-13 e o deslocamento da população muçulmana para áreas habitadas pelos armênios do Império Otomano, Almeida entende que "o problema então foi assentar as centenas de milhares de muçulmanos que antes viviam nos países livres e foram deslocados para viver dentro do Império. A maior parte foi instalada ao longo das estradas ou em terras armênias, fazendo ressurgir o problema conhecido como "Questão Armênia” (ALMEIDA, 2012: 7).

77 Segundo o autor foi por meio da "Oficina para el assentamiento de Tribus y Refugiados del Ministério del Interior (IAMM)” que circulavam os telegramas. (Akçam, 2010: 259). 
equipamento agrícola, sementes (...) os deportados seriam indenizados pelos bens e objetos de valor que haviam deixado para trás” (2010: 256).

Akçam mostra que dinheiro e bens dos armênios foram destinados a "cinco preocupações essenciais”: 1) Engrandecer a burguesia muçulmana - venda ou transferência das propriedades armênias para a população “a um preço razoável”, bem como para transferir “mediante o uso de ações a ser adquiridas pelos empresários e agricultores”, ou ainda transferências dos “ estabelecimentos conectados com o artesanato e o comércio aos muçulmanos, as existências nos armazéns abandonados deverão ser vendidas a crédito a jovens honoráveis” ${ }^{78}$; 2) Prover a necessidade de novos imigrantes - aos governos regionais de Ancara, Adana, Alepo, Izmit, Urfa, Eskishehir, Ganik e outras ordens são assinaladas para que "se estabeleçam nas propriedades abandonadas, se dê provisões e empregos disponíveis” ${ }^{79}$; 3) Para satisfazer as necessidades dos militares, que também expropriou aos gregos na ocasião - confiscados bens, mercadorias em Kütahya, moenda e processador de cultivos “abandonados pelos armênios” em Urfa, no lado grego, em Çanakkalé e Dardanelos o exército queria as uvas dos vinhedos; 4) Para cobrir os gastos das deportações - os próprios armênios custearam suas deportações, dinheiro de venda de gado e de casas abandonadas foram destinados à Comissão para a Administração de Bens Abandonados em Alepo; 5) Para cobrir outras necessidades do Estado - tais como o uso edifícios armênios para cárcere em "Edirne, Adana, Ancara, Icel, Nigde”80.

Com o plano do Genocídio sendo executado pelo menos desde o final de maio de 1915, os armênios representavam e, materialmente muitas vezes eram, para além da figura do infiel ao Islã, os capitalistas que exploravam os muçulmanos. Na perspectiva do Estado otomano voltado à formação nacional turca, recaía sobre os armênios a personificação do capital que se expandia em outras mãos que não as turcas. Nesse ponto há mais uma proximidade em relação ao Holocausto, uma vez que o antissemitismo ${ }^{81}$ associou a ruína da Alemanha com a ascensão financeira dos judeus. Os armênios “assumem papel parecido com judeus na Europa Cristã, transformando-se em banqueiros, artesãos hábeis, burocratas e homens de negócio, alguns mesmo chegando ao papel de conselheiros dos sultões” (MIRAK apud GRÜN, 1992: 15).

78 Idem: 259.

79 Ibid.:260.

80 Idem.:260

81 Sobre a questão do antissemitismo, assunto importantíssimo para se pensar as dinâmicas de crise do capital e essa histórica pesonificação ideológica, mas que aqui não será tratado em detalhe. Para isso, ver entrevista de Moishe Postone entitulada "Sionismo, antisemitismo e a esquerda" disponível em: http://o-becopt.blogspot.com.br/2012/03/moishe-postone 2733.html . Outra interessante crítica de Robert Kurz sobre o assunto foi escrita sob o título de "Economia política do anti-semitismo" escrito em 1995 e disponível em: http://www.obecoonline.org/rkurz164.htm Ver também o quarto capítulo de Kurz (2003) com o nome de "O próximo Oriente e a síndrome do antisemitismo". Há uma discussão no segundo item sobre o sobre o antisemitismo como uma "ideologia de crise". 
Sobre a situação dos armênios e sua posição econômica na Porta, Freitas afirma em sua Tese “Falam os imigrantes: memória e diversidade cultural em São Paulo” que estes “chegaram a ter uma situação semelhante a dos judeus na Europa, que constituíam uma minoria religiosa, mas muito ativa economicamente” (FREITAS, 2001: 82; grifos nossos). ${ }^{82}$ Ainda sobre o lugar dos armênios na economia do Império, vale dizer que alguns autores afirmam que essa posição destacada não representava a maioria:

Construíram-se então grandes fortunas; comerciantes importantes e mesmo banqueiros do império
eram armênios, principalmente os que viviam nas maiores cidades - Constantinopla (Istambul) e
Esmirna (Izmir). Muitos eram profissionais liberais, médicos, artesãos, intérpretes do governo. A
maioria do povo armênio, entretanto, manteve-se como agricultor, vivendo em pequenas vilas,
principalmente na Anatólia Oriental. Nessa região, dividiam espaço com tribos curdas e
circassianas, na maioria nômades, e a relação entre esses povos tinha um delicado equilíbrio que se
manteve enquanto o Império era poderoso e bem administrado. Os armênios costumavam abrigar
os curdos nômades durante o inverno e pagar a eles por proteção. Quando o Estado Otomano
tornou-se decadente e a política corrupta, os impostos devidos ao governo se tornaram exagerados,
o que impedia os armênios de pagar, além disso, a taxa de proteção aos curdos (ALMEIDA, 2012:
4).

Ligia Almeida, autora do artigo “Genocídio Armênio: a história e a 'verdade oficial””, aponta para a relação entre os armênios e as outras populações dentro da administração otomana, que é de grande importância para se pensar também a expropriação e repovoamento das regiões onde armênios e outros cristãos foram deportados. No artigo intitulado “Genocídio Armênio (19151923): massacre, deportações, expropriação”, o argumento de Loureiro mostra duas formas de representação do povo armênio, de um lado agricultores das bandas orientais como maioria e do outro lado uma burguesia ativa no comércio. Este último grupo figura ao lado dos gregos e também judeus, personificando uma burguesia especialmente em Istanbul (2013: 37). Muitas vezes tal grupo foi apontado por cobrar preços injustos no interior da Anatólia, gerando revolta e diferenciação entre turcos camponeses que se sentiam exurpados pelo capital comercial cristão ${ }^{83}$.

Os problemas do direito do Estado otomano em não homogenizar seus súditos e minorias atravessa o século XIX e adentra o século XX. O estatuto de inferioridade, a aplicação não padronizada da lei (Sharia inclusa) são pequenas brechas do direito quando comparadas a uma política sistemática de extermínio consolidada a partir da guerra de 1914. As caravanas de deportação eram lideradas especialmente por três grupos: a Organização Especial, mas também

82“ Durante a existência do Império Otomano, os armênios tiveram uma coexistência pacífica com os turcos. Havia uma certa tolerância por parte do governo que lhes concedeu direitos religiosos e civis. Mas eles eram considerados uma espécie de cidadãos de segunda categoria. Não tinham os mesmos direitos dos turcos e estavam sujeitos ao pagamento de taxas frequentemente extorsivas. Os armênios prosperaram e muitos chegaram a ocupar posições de destaque como banqueiros, financistas, comerciantes. Chegaram a ter uma situação semelhante a dos judeus na Europa, que constituíam uma minoria religiosa, mas muito ativa economicamente (FREITAS, 2001: 82; grifos nossos). 83 De toda forma, antes da abstração que reduz as qualidades de pessoas tão diferentes como “cristão” simplesmente, dentro da próprio Ermeni Millet, famoso por sua fidelidade otomana (nação armênia sob administração otomana) havia a redução de três grupos armênios - apostólicos, católicos e protestantes - representados pelo patriarcado da Igreja Apostólica de Constantinopla que era indicado pela administração otomana. Ver Loureiro (2013: 33). 
foram convocados para participar os gendarmes (polícia do interior) e as tribos curdas, os Hamidiye $^{84}$, que haviam sido organizados por Abdul Hamid II na década de 1890:

Con el establecimento de los regimentos Hamidiye podemos ver que el mecanismo de la "recompensa" para tratar duramente com los armenios comenzó a ganar un carácter más sistemático. Los gastos para estas unidades fueron cobiertos por las ganancias acumuladas a través de la opressión, el robo y la muerte que ellos realizaron. Los miembros de estas unidades fueron exentos de impuestos, y el Estado, a menudo, dio tierras a sus tribus. Tanto estas recompensas como su institucionalización jugarían un papel crucial como factor exarcerbante em la matanza masiva por venir (Akçam, 2010: 70).

Em meio aos conflitos e derrotas para a Rússia durante a guerra de 1914, os unionistas deliberam um conjunto de medidas militares contra a população armênia sob o pretexto de “reestabelecer a ordem em zonas de guerra”, alegavam traição e conivência com o inimigo russo. Bruneteau afirma, no entanto, que essas justificativas de repressão eram frágeis e foram desmentidas por diversos testemunhos internacionais (o historiador Arnold Toynbee e Lord Bryce na Câmara de Londres em 06 de outubro de 1915, Pastor Johannes Lepsius, Embaixador americano na Turquia Henry Morgenthau, o jornalista alemão Harry Stuermer e o primeiro ministro britânico William Gladstone, são fontes em oposição à história oficial negacionista). Esses testemunhos de diplomatas, jornalistas, religiosos são importantes na medida em que reportam a fatos semelhantes ocorridos em regiões distintas dentro do Império Otomano, o que comprova a intenção genocida do governo (Bruneteau, 2008: 68-69).

As estratégias para a execução do Genocídio Armênio tem o fatídico dia 24 de Abril de 1915 como data simbólica. Por ordem do Ministério do Interior, todos os notáveis, intelectuais e dirigentes comunitários armênios foram presos por conta de uma suposta hostilidade relativa ao Estado e propensão à traição em meio aos conflitos. Ainda que o dia 24 de Abril seja o marco do Genocídio Armênio do ponto de vista político até os dias atuais, as práticas de extermínio se iniciaram já em 1914, quando “os armênios mobilizados no exército desde Novembro (...) eram desarmados, reagrupados e sumariamente massacrados em grupos enormes.” Outra forma de extermínio perpetrada durante a guerra consistia em mobilizar os jovens entre 15 e 20 anos e homens mais velhos, de 45 a 60 anos, para realizar trabalhos pesados e esgotantes e também para serem usados na manutenção rodoviária, antes de serem exterminados em massa (Bruneteau, 2008: 69). As operações de extermínio e deportação se deram de algumas maneiras:

Em certas províncias, não houve deportações, mas o massacre imediato. Noutras, foram deportadas pessoas, mas ocorreram massacres por etapas, uma vez que, por exemplo, as vítimas eram atiradas aos rios amarradas duas a duas. O Eufrates arrastou assim durante semanas cadáveres que se acumulavam nos bancos de areia, servindo de alimento aos cães e aos abutres.

84 Pude visitar em Yerevan o memorial Tsitsenakaberd e o Museu do Genocídio Armênio. Não relato isso em nenhuma parte, o museu é um bunker cruel e sinistro. Vale a lembrança de três momentos: as fotos dos hamidye, pois vê-los deu outra dimensão depois de ler sobre; a história que Komidas, grande compositor da música armênia, endoideceu depois de 1915; e as fotos das crianças em pele e osso nos orfanatos. De acordo com Akçam: "Los asesinatos fueron coordinados entre la gendarmería, la Organización Especial y las tribus kurdas.” (2010: 236) 
No entanto, na maior parte dos casos, a população fez-se à estrada em comboios escoltada por polícias, e, mesmo que não se verificassem massacres em massa, ela foi sendo gradualmente dizimada pela doença (tifo), pelo esgotamento (execução dos retardatários) e pelas privações (água racionada) (BRUNETAU, 2008: 70-71).

As descrições do horror da deportação são inúmeras, enquanto estratégia de extermínio, as marchas da morte reduziram a população armênia praticamente aos ossos que ainda hoje se encontram nos desertos da Síria e Mesopotâmia ${ }^{85}$ (há casos em que morreram 96\% dos armênios que iniciaram a marcha). Akçam, relata que "cuando las caravanas pasaban por una zona poblada, también eran atacadas y saqueadas. Los que estaban muy enfermos y exaustos para marchar, morían donde caían.” (2010: 248) ${ }^{86}$. Há ainda que se destacar que dentre os sobreviventes, muitos acabaram por se fundir entre a população turca quando foram islamizados, "turquificados" ${ }^{87}$, submetidos ao chamado genocídio branco.

Para Akçam (2010: 176), "las medidas antiarmenias ya habían comenzado com la declaración de movilización general el 2 de agosto de 1914” e diz ainda que neste mesmo dia o Comitê Central do CUP editou ordens para formar a Organização Especial na Anatólia Oriental, que passava então a armar grupos irregulares. Pode-se dizer ainda segundo Akçam, que a criação de tal organização tinha também como intuito não envolver o Exército - ainda que em certos momentos isso tenha acontecido, mas não de maneira decisiva para o planejamento e execução do Genocídio Armênio - de modo a evitar com que a execução dos massacres e deportações passasse pelo interior do Estado gerido pelo CUP e deixasse registros também militares. No entanto, os registros dos telégrafos desmascaram a intenção genocida mesmo que seus executores não estivessem oficialmente vinculados ao Estado ${ }^{88}$.

Recorremos novamente ao discurso de Bryce pela força de ser uma denúncia feita à época dos acontecimentos, quando da mobilização geral (Gaudemar, 1981) nas deportações em massa. Assim como em Toynbee, vê-se forte carga eurocêntrica, característica do pensamento de época que acaba por polarizar ocidentais e orientais:

(...) a maneira de proceder era extremamente sistemática. Todos os habitantes armênios de cada cidade ou aldeia eram expulsos de suas casas depois de buscas domiciliares e, uma vez na rua,

85 O filme Grandma’s Tatto de Suzanne Khardalian mostra - entre outras coisas, em especial a forma como as mulheres turquificadas eram violentadas sexualmente e tatuadas para marcar essa distinção - que ainda hoje existem ossos das vítimas do genocídio nos desertos da Síria.

86 Traduzido: “quando as caravanas passavam por uma zona povoada, também eram atacadas e saqueadas. Os que estavam muito enfermos e exaustos para marchar, morriam donde caíam.” (Akçam, 2010: 248)

87 Assunto abordado no relato Yerevan, 22 de setembro.

88 Sobre isso, nos diz Almeida (2012:10) que "uma vez que a Organização Especial não era reconhecida como um destacamento estatal e os criminosos contratados tampouco, o governo podia, com facilidade, esquivar-se das responsabilidades caso isso fosse verificado. De fato, a versão turca atual fala de 'situações fora do controle' e 'casos de vingança por parte dos locais'”. 
alguns dos homens eram lançados na prisão, onde eram executados, algumas vezes, depois de torturados; o resto dos homens com as mulheres e crianças eram mandados para fora da povoação. Depois de chegar a certa distância, separavam-se e os homens eram levados para qualquer lugar nas montanhas onde os soldados ou as tribos curdas, que tinham sido chamados para prestarem seu concurso nesta chacina, os exterminavam a tiro ou a baioneta. As mulheres, crianças e velhos eram mandados escoltados com soldados da mais baixa espécie, muitos deles acabados de sair das prisões, para seu longínquo destino, que era, às vezes, um dos distritos insalubres no centro da Ásia Menor, mas, com mais frequência, o grande deserto na província de Del-el-Zor, que se acha ao leste de Aleppo na direção do Eufrates. Dias e dias tinham que marchar impelidos pelos soldados, a pé, espancados ou abandonados à morte se não tinham já forças para acompanhar a caravana; muitos eram os que ficavam pelo caminho ou que morriam de fome. O governo turco não lhes fornecia provisão alguma e, pelo contrário, os espoliavam de tudo quanto possuíam. Não poucas das mulheres eram obrigadas a caminhar despidas debaixo de um sol ardente. Algumas mães enlouqueceram e abandonaram seus filhos, por já não terem força para carregá-los (BRYCE, 2003: 19).

Durante a guerra de 1914 alguns dispositivos de mobilização foram complexificados. A deportação em massa seguida de morte revolveu as areias do deserto de Del-El-Zor e tingiu de vermelho o rio Eufrates. Mas a mobilização de todos fez também vítimas nos campos de batalha, sendo alguns recrutados exterminados antes de ir para o front.

Houve ainda aqueles que trabalharam até a morte ou até serem executados à beira das estradas em manutenção que cruzavam a Anatólia. Kurz (1999 e 2003) aproxima-se da ideia desenvolvida por Gaudemar (1981) ao falar que a guerra instaura um nível de produtividade e acumulação ao qual a sociedade civil não poderá prescindir ao término dos conflitos ${ }^{89}$. “(...) La guerra, exterior o interior, se convierte em uma fuente de economias externas baseadas em este empleo de uma política violenta de movilidad; se deporta, se fuerza al trabajo.” ${ }^{0}$ Já não se trata de aprisionar unicamente forças de combate, forças da palavra, ou qualquer tipo de resistência, mas também forças de trabalho. A manutenção das estradas na Anatólia mostra como os planos dos Jovens Turcos tinham também na mobilização forçada ao trabalho (até a morte) mais uma das formas sanguinárias para se acumular capital, forma que a Alemanha nazista usou e abusou na Segunda Guerra. A noção de mobilidade perfeita encontra sua forma real de existência na guerra ${ }^{91}$, “a força político-militar do exército ou da polícia não são meios exclusivos de destruir o inimigo, externo ou interno, são também força produtora de trabalho” (Gaudemar, 1981:19).

A execução do Genocídio Armênio representa a mobilização geral não apenas aos deportados, expropriados ou recrutados, mas também a todo aparato envolvido pelo Estado, como

89 Tomamos a tarefa de traduzir a tradução que José Saavedra fez de Gaudemar em La molizacion general (1981), dupla traição: "As formas de mobilidade originadas pela guerra não apareceriam mais adiante como aberrações, mas que, ao contrário, constituiriam, realizariam uma norma a alcançar. A mobilidade geral não seria adiante um parêntesis doloroso na história de um povo, mas expressaria a tendência a longo prazo do complexo emprego das forças de trabalho exigido para o desenvolvimento capitalista...Como dizer que vida econômica continua a guerra através dos meios da sociedade civil. Guerra civil fria cujos lugares seriam a fábrica e o mercado de trabalho (Gaudemar, 1981: 2021)".

90 Gaudemar, 1981:19

91 Nesses termos que o autor coloca uma pergunta-hipótese: "por acaso a guerra não coloca um modelo de mobilidade perfeita dos homens?” 
demonstra a correspondência telegráfica, analisada por Akçam (2010). A guerra caracteriza-se como um momento radical de produção da força de trabalho, mais do que na fábrica, na sua contraposição pelos trabalhos forçados (campos de trabalho). O que apareceria como absurdo/abominável, mais adiante torna-se comum. Coloca-se em oposição um capitalismo que se desenvolve pacificamente e outro capitalismo, em guerra, como aberração histórica (pontual). Para Gaudemar no entanto, durante o século XX, tal oposição acaba deixa de existir e a mobilização geral passa a ser constante. Ambos são na verdade um a prolongação do outro. Os campos de trabalho como a forma mais desenvolvida do outro, o fenômeno geral, o trabalho industrial, que aparece como a forma mais exitosa e contraditória do capital acumular pela exploração do trabalho.

Essa forma de mobilização pela guerra ou mobilização geral é muito mais eficaz em comparação com o que o autor entende como "balbucios” que se constituíram as perseguições aos vagabundos e seu encarceramento. Desta perspectiva, considerar a guerra como um momento de exceção, inclusive do ponto de vista analítico, é um equívoco; pois o fazer da guerra tem um papel econômico e social considerável, que desenvolve os modos de organização, mobilidade para o trabalho e as mais adequadas formas de acumulação. A mobilização geral é um um movimento em conjunto. Não está restrita às forças de combate e se manifesta em todas as formas de mobilização do e para o trabalho: imigração, escola ${ }^{92}$, cursos, criminalização e encarceramento. Também pode-se pensar que ela rege, enquanto lógica do tempo abstrato e das necessidades da reprodução da força de trabalho, as esferas cindidas e apagadas da dupla socialização, a exemplo do cuidado das crianças, a comida do marido e, obviamente, a manutenção da casa que historicamente incidem sobre a mulher. Nesse sentido que a guerra de 1914 é um divisor de águas na modernidade, porque alçou as forças produtivas e os padrões de acumulação a um patamar em que se faz necessário a mobilização total da sociedade e a imagem das mulheres trabalhando na fábrica de armas expressa muito bem esse novo momento histórico alcançado pela relação-capital.

Uma periodização é feita por Gaudemar ao referir-se ao caso da modernização francesa que se estende de 1880 a 1914, ou até mesmo até 1945 - em relação às técnicas de mobilização “primitiva” e ao êxodo rural, momento coincidente àquele da alteração da imigração estrangeira. As pessoas oriundas do campo passam ocupar, além dos cargos relativos a indústria, todo tipo de trabalho requerido pela reprodução social do capital nos meios urbanos. O êxodo rural se torna o

92 A escola, que também passa por mudanças, começa a ser o principal centro das políticas econômicas e com a obrigatoriedade instituída iniciam-se debates e articulações entre educação e sistema produtivo (futuramente ensino técnico). Há estreita ligação no argumento do autor entre obrigatoriedade escolar e naturalização da reprodução social enquanto força de trabalho; uma vez que a mobilização escolar é parte constitutiva da mobilização geral, ela contribui para uma naturalização dessa condição de reprodução de força de trabalho com determinadas etapas de mobilização. Nesse movimento que Gaudemar entende que aos poucos vai se “esfumaçando”, “diluindo” a concepção da reprodução das forças de trabalho como exterioridade absoluta. 
“reclutador para el conjunto de la estructura productiva” (1981: 250). Por isso, rapidamente desaparece o tal caráter “exógeno”, no sentido de uma relação não-capitalista, com a penetração do capital em meios rurais, mais especificamente em ambientes agrícolas. Nesse ponto Gaudemar apresenta um argumento que reconhece duas lógicas operando em paralelo, modos de produção não-capitalistas e capitalistas, em que as relações do campo passam a ser açambarcadas pelas relações capitalistas $^{93}$. Talvez haja nesse entendimento uma associação implícita entre relações capitalistas como industriais e relações não-capitalistas enquanto produção no campo. A imigração estrangeira, por outro lado, toma o aspecto da exogeneidade ao se tornar fonte para a substituição da mão de obra industrial francesa. Antes ela significava apenas um "elemento da circulação internacional de trabalhadores”, no período pré-guerra de 1914, os imigrantes representam a forma predominante de recrutamento ao trabalho.

La imigración extranjera se incrementa de uma manera considerable y juega, vista la escasez de mano de obra francesa, um papel de alistamento muy importante; constituye, entonces, la base de las reservas de mano de obra. Su carácter exógeno se mantiene, aunque ya relativizado por una cierta internacionalización de la economia europea (1981: 251-2) ${ }^{94}$.

Além da saída à América, os armênios refugiados substituem mão de obra na França no entre guerras, como em Marselha, uma cidade onde muitos armênios conseguiram permanecer. Uma guerra de reordenamento mundial necessariamente reordena populações para o capital, as deporta, desloca, emprega, concede, ensina, entrega, explora, julga, encarcera, desemprega, extermina e sabota ${ }^{95}$.

Assim, pensando mobilização geral do Genocídio Armênio, é possível dizer que suas práticas acumularam, ou ao menos centralizaram capital pelo trabalho forçado, pelas casas (não havia propriedade privada da terra na Porta ${ }^{96}$ ), pelos bens espoliados e roubados, pela mão de obra

93 Podemos observar problema parecido na obra mais consagrada de Gaudemar sobre a mobilidade do trabalho (1977: 210), que faz uma leitura em que o trabalho sempre existiu, mas o que torna o capitalismo difente desse trabalho ontológico de “economia mercantil”, é sua transformação do trabalho em força de trabalho, a mercadoria que incorpora valor às mercadorias, além de sua qualidade em ser móvel, o que altera a qualidade das migrações como "determinação específica da economia capitalista”.

94 Ao retratar historicamente o que depois dessa periodização, o argumento de Gaudemar pensa haver maior dificuldade de recrutamento de trabalho através da imigração uma vez que os países de origem estão cada vez mais imersos em relações capitalistas, ao invés das relações exteriores, exógenas. Há, portanto, uma formação internacional de mercados de trabalho internos aos países no pós-guerra. Já nos anos 1960, o autor entende que há uma espécie de estabilização nas formas de recrutamento endógenas. (Gaudemar, 1981: capítulo 8).

95 A partir disso, porém, podemos tornar o argumento mais encorpado e crítico ao pensarmos a mobilização geral associada ao fenômeno cada vez mais abrangente da substituição do trabalho humano abstrato pela gestão financeira remota, que se realiza a partir dos microcomputadores, robôs e todo aparato técnico (como fibra ótica) aqui entendido como parte componente das forças produtivas médias do capital nesse mundo contemporâneo que julga esse aparato imprescindível e as pessoas, supérfluas. A história da humanidade como elogio e descrição da evolução técnica não vai além da ilusão do sujeito da fenomenologia que, sem perceber, é um apolegeta da concorrência.

96 Este é um tema que carece de mais estudos, bem como as posições sociais nas diversas partes do Império Otomano que aos poucos vão colando nas identificações de raça e religião, mas aqui podemos brevemente citar o que diz Loureiro ao dizer que "não havia propriedade privada de terra nos limites do Império, sendo todos os latifúndios - dos Bálcãs à Anatólia - pertencentes ao Sultão. Tal prática não permitia a criação de uma elite fundiária. Esta era de caráter 
dos sobreviventes turquificados e puderam, ainda, gozar da violência sexual relativa às mulheres que sobreviveram por serem hurí (belas donzelas). A eliminação física do armênio não bastou; o genocídio teve de acabar com a história, com a língua e normatizar tudo por um mediador nacional turco (dinheiro, cultura, língua, símbolos, história oficial).

essencialmente administrativa em que 'honra e riqueza confundiam-se com o Estado e a posição social derivava simplesmente de postos ocupados em seu seio’ (Anderson, 1989: 365). (Loureiro, 2013: 35). Ainda nesse sentido: “Como não havia propriedade privada da terra, a concessão do uso destas, bem como de cargos administrativos, eram as principais distinções aristocráticas otomanas. Destarte, torna-se compreensível o efeito devastador que o estancamento das fronteiras e a influência otomana teve sobre a sociedade” (idem: 37).

Para esse mesmo assunto de política agrária e administração otomana conferir a comunicação publicada nos anais do VIII Simpósio Nacional de Professores Universitários de História em 1976 por Yessai Ohannes Kerouzian e Beatriz Diniz e entitulado "Política agrária na Armênia ocidental sob o Império Otomano nos séculos XIX e XX (de 1850 a 1914). Kerouzian e Diniz, 1976. 


\section{6) Yerevan, 19 de setembro de 2016}

Estou de volta à capital da Armênia desde o dia 10. As atividades laborais agora estão distribuídas em dois locais: a escola Aybschool e a Biblioteca Nacional Armênia. No primeiro dia que visitei o lugar, terça-feira dia 13, fui guiado pelos cinco andares do prédio de trás da biblioteca, onde estão os documentos, jornais antigos, escritos em armênio, russo, francês e outras línguas. Para o russo há uma sala inteira reservada. É notável como a esmagadora maioria que trabalha nesse prédio é composta por mulheres, em cada pequena sala, departamento, corredor, praticamente só se vê mulheres a trabalhar. No primeiro dia adentrei no suntuoso prédio que dá para rua Teryan, o prédio com uma bonita sala de estudos aberta ao público com janelas viradas para rua. 


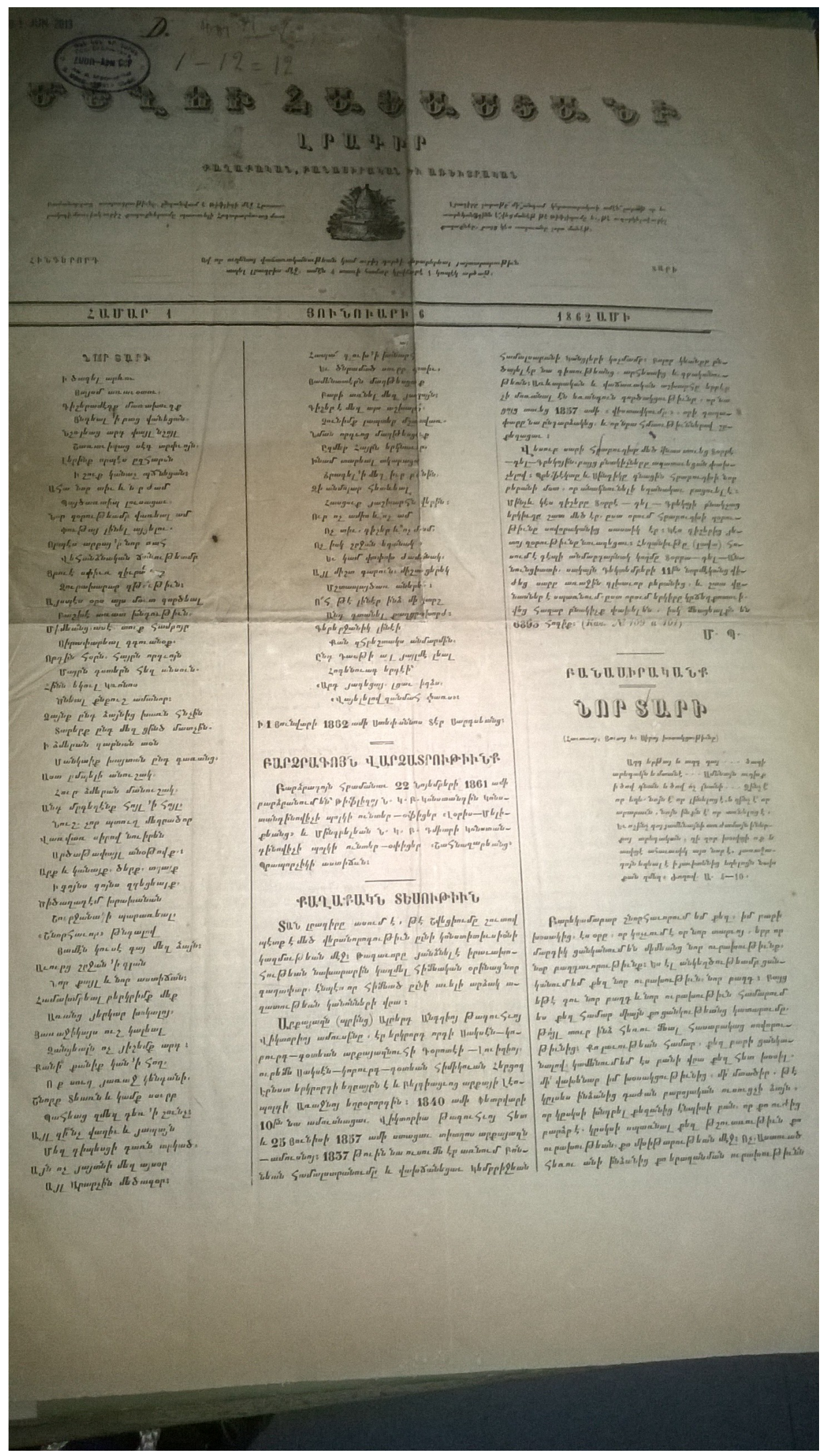

Foto 10 - Pude ver o primeiro jornal armênio dentro do Império Otomano que data de 1862, mas segundo o historiador Heitor Loureiro, existe um periódico ainda mais velho que fora publicado na Índia, ainda no século XVIII. 
Já na escola Ayb, tenho duas aulas na quinta-feira e apenas uma na sexta-feira. É uma escola particular daquelas exemplo e localiza-se na borda da cidade, perto de Abovyan, cidade colada à capital. Tudo funcionando perfeitamente, uma cantina cheia de equipamentos, estúdio musical, sala para fabricação de robôs e outras parafernalhas eletrônicas. Quando estava indo visitar pela primeira vez, indaguei Lusine se outras escolas não precisavam mais de mim do que aquela, mas parece que em Yerevan, ao contrário de Gyumri, o programa de voluntários não conta com tradutores inglêsarmênio e, como nas escolas públicas o inglês dos estudantes não é fluente, me mandaram para a escola dos abastados. No primeiro dia em que trabalhei, fui guiado, em inglês, por duas meninas de quinze anos que apresentaram toda a escola e especialmente uma delas era completamente deslumbrada com a instituição. À certa altura, quando esta mostrava um dos vários quadros situados nas paredes em que se pode escrever, mandar recados, etc., perguntei o que acontecia se escrevessem coisas inadequadas e ela disse que o estudante era chamado para conversar, ao que logo respondi: “escola não se trata apenas de aprendizado, mas também de coerção e disciplina” , ela deu um sorriso e seguiu seu trabalho.

Os primeiros encontros já aconteceram, em uma atividade acompanhada pelo professor de Geografia e quatro estudantes entre quinze e dezesseis anos de idade. No primeiro encontro, a pedido do professor Vahram, elaborei uma apresentação sobre minha relação com a Geografia e algumas questões. De início fui orientado a apresentar autores de Geografia econômica, Cristaller, foi um dos citados. Mas até aqui apresentei questões mais relacionadas à história do pensamento geográfico, sua institucionalização nas escolas e academias e a histórica e estreita relação entre a disciplina e o planejamento do Estado. Perguntei aos estudantes se para eles existia neutralidade na ciência. Um jovem que diz querer ser bussinesman afirmou que em certos momentos sim, quando, por exemplo, "se estudo a ação do vento, a ciência é neutra”. Outra estudante disse que sim e não e por aí foi a conversa. No segundo encontro, apresentei algo como Geografia dos assuntos do campo, abordando o conceito de "plantation" e suas remanescências na realidade atual do Brasil. Latifúndio, monocultura, amplo poder das corporações produtoras de OGM's e a maneira como o poder está atrelado entre latifúndio e a alta política na atualidade. Nessa semana assistiremos ao filme “O veneno está na mesa”, de Sílvio Tendler e vamos ver para onde vai o debate.

No último sábado estive presente na excursão em que caminhamos entre os monastérios que passaram de mil e quinhentos anos, Hovhanavank e Saghmosavank. Hoje são igrejas das mais tradicionais, poucas imagens, para que os fiéis fiquem em contato mais direto possível com seu Deus. Uma arquitetura incrível, a igreja tem um formato de cruz e ao fundo do altar há uma janela vertical que está alinhada com a chegada das três marias no céu da região, o que acontece mais ou menos em 10 de agosto e simboliza o ano novo para a Igreja Apostólica Armênia. Ao que consta, 
São Gregório, o Iluminador, esteve presente na construção de Hovhanavank, que presta homenagem à São João Batista. A capela, ao lado esquerdo que compõem a cruz, foi transformada e tem um aspecto mais próximo à Igreja Ortodoxa Russa, com mais cores, adornos e imagens.

A jovem Lilit, uma historiadora de 23 anos que estudou o peronismo no mestrado nos guiou nas duas visitas, com ela fui conversando em espanhol, que ela fala perfeitamente, boa parte do caminho sobre a história transhistórica da Armênia. Contou da dominação persa sobre a “Armênia do Leste” durante seis séculos até a passagem para a dominação russa no início do século XIX, e no lado otomano, dominação otomana que vem desde a tomada de Constantinopla em 1453. Prometi que vou entrevistá-la e a entrevista transcrita será mais interessante do que qualquer descrição de nossas conversas. Porém, algo digno de nota foi a opinião de Lilit acerca da retaliação ao Genocídio. A ela já não importa mais as terras perdidas, mas sim a luta para transformar a sociedade armênia atual e disse que isso é motivo de discussão com a geração mais antiga, como seu pai. Aqui, otra vez más, a fala de Kiki em Montevideo veio à tona, pois Lilit concorda que o Genocídio é um capítulo tão doloroso que é melhor pensar nos problemas da atualidade, algo muito distinto do “reinvindico e demando”, bandeira internacional da assim chamada diáspora armênia no que diz respeito ao Genocídio Armênio. A identidade que se busca forjar nessas bandas, pelo menos para alguns, aponta para outros lados que a memória que a diáspora tem trabalhado para construir. 


\section{7) Yerevan, 10 de outubro}

De repente quis dar minhas mãos a Drummond:

Mãos Dadas

Não serei o poeta de um mundo caduco.

Também não cantarei o mundo futuro.

Estou preso à vida e olho meus companheiros.

Estão taciturnos mas nutrem grandes esperanças.

Entre eles, considero a enorme realidade.

$O$ presente é tão grande, não nos afastemos.

Não nos afastemos muito, vamos de mãos dadas.

Não serei o cantor de uma mulher, de uma história, não direi os suspiros ao anoitecer, a paisagem vista da janela, não distribuirei entorpecentes ou cartas de suicida, não fugirei para as ilhas nem serei raptado por serafins.

o tempo é a minha matéria, do tempo presente, os homens presentes, a vida presente.

Carlos Drummond de Andrade

O presente é tão grande, como abarcar propriamente essa viagem toda? O presente é tão grande e nele estou sentado num boureau enquanto Varta, que é Rosa em armênio, trabalha duro a limpar o chão desse boureau que é uma seção no quinto andar da Biblioteca Nacional da Armênia onde cada um em frente ao seu mundo tela faz, assim como eu, trabalhos desimportantes ou em vias de serem extintos. E Rosa, perdão, Varta é um incessante chap chap com sua curta e molhada vassoura de palha sem cabo, tão comumente utilizada por essas bandas. Perdi o tempo, o timing de iniciar a conversa com o quase automático “Barev dzez”, que por muitas vezes é respondido na dor da indiferença: "Voch inch”.

Voch inch, é quase o "tanto faz" e em muitos casos carrega um pouco de cada trajetória pessoal e uma história sangrenta daquilo que se denomina Armênia; o que é a nação se não uma mentira compartilhada? Uma tradição, várias invenções. Mas é por isso mesmo, na particularidade 
de ser uma história como essa, mais uma narrativa dentre as que compõem outras tantas nações e nacionalismos, que ela expressa a rubra cor dos mares navegados pelos barcos imaginários do nacional.

Gostaria de não ser um estudioso de um mundo caduco condenado a morrer de tédio em frente a um computador, ser um computa-espectador das guerras que se acumulam e se banalizam pela rede mundial de computadores. O presente é tão grande, mas tão vazio quando só se escuta o monólogo da mercadoria e seus encantos.

Na sexta-feira uma apresentação sobre Karabakh por Richard Giragosian ${ }^{97}$ nos foi cedida como um havak, que são os encontros organizados com temas variados pelo BirthRight aos quais os voluntários devem comparecer em 50\% durante suas semanas de trabalho. A ideia era aprofundar o entendimento sobre o conflito entre Armênia e Azerbaijão antes de irmos visitar a região de Nagorno-Karabakh, ou território de Artsakh para alguns armênios. Seguem algumas das análises expostas pelo palestrante sobre tal conflito.

Em abril de 2016 ocorreram quatro dias de guerra ${ }^{98}$, entre 02 e 05 de abril, em uma ofensiva do Azerbaijão, ataques que fizeram parte de uma escalada no número de ataques que têm ocorrido nos últimos anos, sendo esses ataques de abril os mais intensos, dando ao Azerbaijão a primeira vitória desde 1994 que parece vir em bom momento ao governo de Aliyev filho, pois tem sido utilizada como uma espécie de distração política frente à crise econômica que o país enfrenta após a queda de preço do petróleo. Desde o armistício em 1994 os armênios eram e assim se entendiam como melhor preparados, mas os resultados de abril de 2016 criaram um alerta. Boys with toys. O palestrante insistia em dizer que hoje com novas armas e tecnologias as táticas também são outras, bem como nos disse que a Rússia não é esse parceiro todo que parte dos armênios entendem. As

97 O convite desse havak assim descreveu o palestrante: Richard Giragosian é o diretor fundador do Centro de Estudos Regionais (RSC), um "think tank" independente localizado em Yerevan, na Armênia. Ele também atua como Professor Visitante e como Especialista Sênior no Centro de Estudos Europeus (CES) da Universidade Estadual de Yerevan e é analista contribuidor da Oxford Analytica, uma empresa global de análise e consultoria em Londres.

Giragosian serviu anteriormente desde 2009-2011 como Diretor do Centro Armênio para Estudos Nacionais e Internacionais (ACNIS), outro grupo de pesquisa na Armênia. De 1999 a 2008, foi colaborador regular das publicações da Radio Free Europe / Radio Liberty (RFE / RL) e também atuou como analista contribuinte para o Jane's Information Group de 2003 a 2010, abrangendo política, economia e segurança Problemas no sul do Cáucaso, Ásia Central e região da Ásia-Pacífico. A partir de 2008-2010, foi colunista regular da edição internacional de língua turca da Newsweek e ainda atua como consultor e assessor de vários meios de comunicação turcos e publicações analíticas.

Durante nove anos, o Giragosian atuou como membro do pessoal profissional do Comitê Econômico Conjunto (JEC) do Congresso dos EUA.

98 Recentemente foi lançado pela Fundação Hran Dink um estudo comparativo sobre o discurso discriminatório da mídia na Armênia, Azerbaijão e Turquia sobre os quatro dias de abril. Disponível em:

http://hrantdink.org/attachments/article/770/FOUR\%20DAY\%20WAR\%20IN\%20NAGORNO-KARABAKH.pdf acesso em 10/07/2017. 
armas mostradas na parada militar no dia 25 de setembro, data da independência da Armênia póscolapso soviético, foram um recado de que a Armênia está bem equipada, inclusive com os aviões não-tripulados russos de alta precisão.

A posição de defesa armênia é vantajosa por sua "geografia”, mas também na ótica de que os armênios pensam a região em conflito como “our land” (nossa terra). O exército de Artsakh não está sob o comando da Armênia, mas depende das armas vindas de lá. Entretanto, do ponto de vista político, a Armênia segue tendo grande influência sobre Artsakh. Para Richard, não apenas a resolução está longe de ser alcançada com o Grupo Minsk, que conta com 11 países e é liderado pela França, Rússia e E.U.A., não é nem forte e nem comprometido suficientemente com o problema e o Azerbaijão continua firme em não abrir mão de buscar novos territórios e ocupá-los. Mais do que isso, o palestrante não acredita que Artsakh deva se tornar independente enquanto país, pois isso não seria viável nem econômicamente nem militarmente. Outro agravante para os armênios nesta perspectiva é a falta de informação que a Armênia detém sobre a realidade do seu vizinho que não é constituído apenas por xiitas, mas também por muçulmanos sunitas e wahabistas. Por outro lado, esta perspectiva vê futuro e possível normalização nas relações entre Armênia e Turquia e um fator que colabora para essa resolução específica nesse argumento se deu com as prisões de militares turcos pró-Azerbaijão após o fracassado golpe de Julho de 2016 na vizinha a oeste.

Se a população “é quem faz um país”, a autodeclarada República Nagorno-Karabakh, ou Artsakh aos armênios, é praticamente um vazio demográfico e hoje conta com pouco mais de 100.000 pessoas residentes. A colonização da região em conflito por armênios da diáspora parece ser bem precária, dotada de pouca infra estrutura e em grande parte voltada às áreas rurais. Os libaneses que se mudaram tinham "terra, ovelhas e só”. Ainda segundo o palestrante, os Princípios de Madrid ${ }^{99}$ são enganosos: "bullshit”.

O reconhecimento do genocído armênio é, segundo Giragossian, somente um ato político para se opor a Erdogan, pois França e Alemanha não estão realmente preocupados. Azeris jovens têm mais ódio que os mais velhos que sentem falta dos tempos em que tinham os armênios como vizinhos. Os armênios jovens, por sua vez, são mais moderados do que os mais velhos que viram e

99 Os princípios de Madrid foram acordados entre os países em conflito, mas não saíram do papel. São eles: Devolução dos sete distritos que rodeiam Nagorno-Karabakh; aprovoação do um status provisional que garantisse segurança e autogoverno da região; manutenção de um corredor que una fisicamente os territórios de Nagorno-Karabakh e Armênia pela localidade de Lachin; determinação no futuro, por meio de uma consulta juridicamente vinculante, o status definitivo do enclave; direito dos deslocados internos e refugiados a regressar a suas famílias; desdobramento de uma missão de paz internacional.

Cf.:http://www.ieee.es/Galerias/fichero/docs opinion/2014/DIEEEO04-2014 Nagorno-

Karabaj Fco.RuizGlez.pdf 
participaram do processo todo. Mas a rivalidade abestalhada não cessa de ser alimentada. Foi oferecida uma recompensa por parte do governo azeri a quem cortasse a orelha do mais famoso escritor pró-Armênia no conflito.

Por fim, sobre o isolado território de Nakhijevan restam poucas esperanças, parece ser um lugar único no mundo o exclave azeri e assim deve permanecer uma vez que esse território não possui grande influencia no conflito atualmente, além do curioso fato de que lá vigoram outras leis em relação às leis do Azerbaijão.

Sábado eliminatórias para a Copa do Mundo da Rússia em 2018. No Estádio Nacional cheio de pedra Tuffa (tuffstone) em Yerevan: Armênia 0 x 5 Romênia. Domingo aghi lidg (lago salgado) com Esteban, voluntário argentino assustado com o brain wash ${ }^{100}$ da armenidade propagado pelo BRArm. Conversamos com moleques no lago e eles pediram "pogh” (dinheiro). Para voltar, carona com taxista que queria ganhar a vida em São Paulo.

100 Lavagem cerebral. 


\section{8) Shushi, 14 de outubro de 2016}

Saída de Yerevan às 08:20 rumo à cidade de Shushi. Café na estrada provido pelo BRArmenia com água, salada, homus, lavash, lahmadjun normal, apimentado e com zatar. Havia búfalos e bois sendo conduzidos na beira da estrada onde havíamos parado. De volta à estrada, aclive por muitos quilômetros, passamos a entrada de Areni e seguimos sentido sul. Mais subidas, áridas montanhas acompanham em ambas janelas até começarem os cotovelos a $180^{\circ}$ nos fazem cortar as nuvens, entrávamos em Tatev e o frio pegava. Outra vegetação no topo e grande variação das cores de ashun (outono). Parada no monastério de Tatev que data do século IX e sua universidade de monges que foi ativa por cinco décadas no século XIV. Em Shushi chegamos tarde e diretamente a um hotel ter com mais jantar daqueles de grandes e variadas mesas, discursos e longas filas de banheiro. Fomos divididos em grupos ou de homem ou de mulher e comigo estavam dois estadunidenses e um argentino, com quem dividi o quarto por duas noites. Já na primeira noite dançamos até às três da matina com a filha de 10 anos de Liana, a mãe de mais duas meninas. $\mathrm{O}$ repertório da mocinha era um catadão do pop caucasiano e não faltaram os dois maiores hits: "Papito Chocolata” e “Eroina”, sugestão para trilha desta leitura. Liana nos encheu de doces, frutas e café. Chá só foi permitido a quem antes engolisse bons tragos de café. Dependíamos quase que totalmente da mediação da língua armênia de um voluntário estadunidense fluente.

Dia seguinte: café da manhã nada leve. Pão, salsicha, queijo, margarina, ovos, mel caseiro, geléia de figo, batata frita, café e chá preto. Saímos a caminhar na ex-cidade soviética ocupada por azeris até 1992 e logo na primeira avenida o prédio novinho da escola vocacional e da Universidade Nacional Armênia de Temas Agrários, contaram-nos que o partido Dashnak (Federação Revolucionária Armênia) doou dinheiro para a construção dos prédios e sob a perspectiva armênia de quem nos guiava, a cidade teve seu “pico” de importância cultural durante o século XI. A reconstrução da cidade tem acontecido gamatz gamatz (aos poucos), muitas casas eram povoadas por azeris já que estes foram maioria durante o período soviético. A arquitetura, entre destroços dessa longa guerra e do contínuo conflito de "baixa intensidade”, mistura conjuntos habitacionais no padrão soviético, novos prédios armênios e construções muçulmanas do século XIX. Há uma mesquita datada de 1883, que segundo nos disseram antes de ser utilizada pelos azeris foi construída e utilizada pelos persas, o que indica que a mesquita vem de antes da última guerra russo-persa em 1826-28. Houve um investimento de capitais, tido como doação uma vez que não se espera retorno e nem a ampliação do investimento, para a renovação do mercado central. 
Sob o domínio do Império Russo que tomou essas terras dos persas em 1828 ao final da Guerra russo-persa, Sushi era uma das três maiores cidades do sul do Cáucaso ao lado de Tiblisi e Baku, atualmente capitais de Geórgia e Azerbaijão, respectivamente. Durante o século XIX era tida como capital cultural, dotada de teatros e jornais locais, mas conta sua história daquele século com o episódio da invasão dos tártaros (povo da Ásia central tido como um dos povos que deram origem aos azeris e turcos) que incendiaram toda a cidade onde há vestígios ainda hoje. Esvaziada, a cidade hoje carece de estabilidade e busca atrair capital estrangeiro para se modernizar. Adentramos o Mercado em reconstrução, um jovem estadunidense estudante de economia me vira e diz: "So, there is nothing”. O primeiro hotel aberto na cidade é de 2001, o segundo de 2009, assim como o Mercado em renovação, investimento da diáspora, esse elemento que ganha ares de banco mundializado do capital armênio nessas horas.

- “E se renovássemos, o que poderia vir a ser”? A pergunta-convite feita pelo diretor do programa de voluntariado faz nos lembrar da relação entre oásis e desertos de rentabilidade desenvolvida por Kurz em “Barbárie, Migração e Guerra de ordenamento mundial ${ }^{101 ”}$. Seria Shushi em sua reconstrução um possível locus para a valorização ficctícia de capitais armênios vindos dos muitos destinos da diáspora? Admitir isso em parte seria acreditar em renda da terra e mercado de imóveis na ascendente numa cidade esquecida no meio de uma "guerra de baixa intensidade".

Fardados da polícia e do exército por toda parte. Na frente da mesquita fardados ajudavam nos reparos de uma das principais ruas da cidade. Seria isso um desdobramento da economia de guerra d'O colapso da modernização (Kurz, 1992) ou a expressão mais sintética da mobilização geral de Gaudemar (1981)?

Para David Harvey (2004) a crise local é global ao pensar o descolamento entre o capital fictício e o capital produtivo que apontam para crises cíclicas. Quais as conseqüências desse descolamento na reprodução do espaço, nas relações sociais de produção? Os capitais excedentes colocam a crise como inerente ao capitalismo, crise periódica paralisa setores produtivos e gera desemprego. A forma neoliberal de acumular está se esgotando, arrocho salarial e de direitos,

101 "Só uma parte das migrações pode ser explicada diretamente pela força de atração econômica coercitiva dos "oásis" de rentabilidade. A outra parte da migração é, todavia, também conseqüência dos processos socioeconômicos globais da crise, mas, antes, de uma forma indirecta. A mesma desertificação econômica que, de um lado, impulsiona grandes massas a procurar sua salvação nos "oásis" de rentabilidade, por outro lado, provoca, nas sociedades das zonas em colapso, guerras civis sem fim. Quem ainda possui um restinho de reserva e de energia, tem a escolha: ou enfrenta o caminho perigoso sobre montanhas, oceanos e fronteiras, para poder, em algum lugar, ainda vender a sua força de trabalho, ou pode juntar-se a um clã armado, um grupo de terror, um bando de saqueadores, uma milícia religiosa ou étnica. Essas duas opções parecem oferecer a única esperança para uma sobrevivência social. Migração socioeconômica e novas guerras civis são os dois lados da mesma moeda. E dessas guerras, nas quais Estados inteiros decaem, surgem infinitos fluxos de refugiados. Os refugiados do terror, do assassinato em massa, e dos saques são apenas uma continuidade da migração socioeconômica em nova qualidade. Ambos os fenômenos possuem a mesma raiz” (KURZ, 2005). 
bolsões de pobreza, grandes fluxos migratórios, crises locais podem transformar-se em crises globais. A produção do espaço aparece como possibilidade de desafogar a crise de acumulação. Será mesmo? O trabalho da produção do espaço, para Harvey (2004), é produtor de valor e, claro, de mercadorias e materialidades. Capital excedente produz espaço, diferenças geográficas movem trabalho para produzir espaço mesmo com dinheiro emprestado a juros altos. Enquanto uns crescem outros se endividam.

A passagem do capital financeiro ao fictício coloca o mercado à parte, como esfera descolada da valorização autonomizada do dinheiro (D-D’), da renda dos capitais creditícios. Nesse sentido, quais são as contra tendências no plano da reprodução social em relação com a queda tendencial da taxa de lucro no plano produtivo? Tragédia social...na produção de mercadorias, para David Harvey, há produção de valor, mas se não há realização do valor é outro problema. Há trabalho explorado a partir do capital fictício, mas essa relação consegue se reproduzir ampliadamente, remunerar esse dinheiro a juros? O salto da mercadoria pode ser mortal, como dizia Marx ao falar do dinheiro na primeira seção d’O capital. O crédito, enquanto venda do futuro é outra forma de supressão temporal - para além da melhoria técnica na circulação do capital e na realização de mercadorias - colocada na continuação dos ciclos, mesmo os deficitários.

O subprime, um crédito imobiliário de alto risco aliado às securitizações de dívidas estourou a bolha na crise de 2008, foi historicamente constituído durante o neoliberalismo do final da década de 1970 adentrando os anos 1980, na expansão do crédito até para pessoas sem condições de pagar. Não por acaso, Neil Smith entende esse período como a segunda fase da gentrificação, a fase de consolidação dessa prática que, para o autor, é tida como política de habitação em NY nesse período. A desregulamentação como característica neoliberal amplia a profusão de muitas espécies de derivativos como forma de transferir riscos, securitizar dívidas, repartir os riscos com sociedade a partir de um fundo de capitais particulares como garantia em um comércio de papéis que toma uma dimensão global, um castelo de cartas de difícil previsão.

O discurso ideológico do urbanismo proferido pelo Estado se inicia no contexto histórico do capitalismo industrial das cidades européias no século XIX através das primeiras Leis Sanitárias e vai se complexificando tanto como discurso como na composição dos capitais ao longo do século $\mathrm{XX}$, em que do urbanismo planejador estatal vai se mostrando um negócio interessante ao capitalismo financeiro, um negócio aparentemente mais seguro do que o capitalismo de cassino, ainda que o primeiro esteja ligado ao segundo inclusive como lastro, garantia, hipoteca, liquidez. Nesse movimento de capitais, a terceira revolução industrial, a microeletrônica, da década de 1970 aparece como um divisor de águas para a rentabilidade dos grandes capitais. Por outro lado, o imobiliário aparece como grande negócio e possibilidade de deslocamento das crises de 
acumulação. É o contexto de inicio do fenômeno da gentrificação que, nas décadas seguintes, tornou-se a política urbana do neoliberalismo e o oásis de acumulação em acirrada disputa entre as pretensas cidades globais dos mega-eventos ou ainda, em escala menor, dos urbanismos higienistas de fragmento. Funcionalidade e embelezamento como legado urbano, expropriação como legado social.

Henri Lefebvre ao tratar das lutas em torno das novas raridades (2008: 66-67) traz elementos para pensarmos a realidade da expansão urbana nas metrópoles brasileiras. Mas será mesmo que projetos de "revitalização" do urbanismo em meio a guerras de baixa intensidade, como em Shushi, podem também constituir novas raridades? O urbanismo reside nesse lugar, nessa encruzilhada de interesses no processo de reprodução do espaço urbano, nesses termos é que afirma o autor: "existe uma política do espaço, pois o espaço é político”.

Diante de seu bureau, portando uma caneta dotada de super poderes que recaem diretamente na vida população supérflua ao processo produtivo, o tecnoburocrata exerce sua qualidade de terrorista do Estado.

Outro autor que aponta para caminhos para se pensar o urbanismo é Jean Pierre Garnier (2011), contribuindo com sua análise crítica a partir da interpretação marxista sobre a apropriação da mais-valia na gestão técno-econômica do espaço. Esse tipo de gestão na qual o Estado tem um papel fundamental carrega a ideologia funcionalista (herança da arquitetura modernista) em que a noção de “desordem” é contraposta pelo bom planejamento, mas interessa ressaltar que para o autor a assim chamada “desordem” não é senão a ordem dos capitais em concorrência, que fragmentam a reprodução do espaço de acordo com seus privados interesses. Ao invés da concepção de desordem advinda da chamada espontaneidade do crescimento urbano sem planejamento, o autor de maneira acertada critica esse processo ao compreender que há certa ordem nessa desordem. A objetividade dos mandos e desmandos do capital nessa relação social de dominação das coisas sobre as pessoas que tem por finalidade a valorização do valor, ou seja, uma relação social fetichista em que a transformação de um dinheiro em dois é a ordem social. A relação social invertida entre os produtos do trabalho, como aponta Marx:

A igualdade dos trabalhos humanos assume a forma material de igual objetividade de valor dos produtos de trabalho, a medida do dispêndio de força de trabalho do homem, por meio de sua duração, assume a forma de grandeza de valor dos produtos do trabalho, finalmente, as relações entre os produtores, em que aquelas características sociais de seus trabalhos são ativadas, assumem a forma de uma relação social entre os produtos de trabalho (1983, vol. 1: 71)

Ainda de acordo com Garnier, a “desordem” do capital em suas formas urbanas “caóticas” tem como princípio, ao invés de sua aparência de mera casualidade, a segregação espacial. A 
planificação urbana, assim, se faz valer da aparência "anárquica” para justificar sua ideologia urbanizante, bradada em uníssono pelos tecnocratas do Estado, empreiteiras e o mercado financeiro vinculado ao imobiliário. O caráter ideológico que repousa sobre o discurso do planejamento urbano visa ordenar as relações de produção e a circulação do capital no espaço atendendo a determinadas classes da sociedade. Outro ponto importante pela perspectiva teórica abordada na interpretação de Garnier é o da urbanização enquanto um fenômeno social, dotado de relações entre classes em disputa e luta, ainda que essas representações de classe estejam colapsadas há algum tempo. Talvez haja aí uma divergência teórica entre o referido autor e Lefebvre, pois o autor francês reivindica uma espécie diversa do comum entendimento de “ciência do espaço”, ou seja, uma compreensão do espaço enquanto totalidade das relações sociais, não o espaço apolítico, neutro e objetivo do planejamento, espaço esse que seria carente de sua própria epistemologia urbanísitica. O espaço de Lefebvre teria o poder de uma categoria totalizante ao se contrapor ao entendimento do urbano como ideologia. Por outro lado, Garnier afirma que a compreensão do urbano como base dos problemas sociais leva a análises de seus problemas em termos de crises e não de contradição, condizendo com a perspectiva da resolução técnica da urbanização, o que esconde a qualidade contraditória das relações sociais de produção, para o autor, nos termos da luta de classes.

Ainda que espaço e urbanização não estejam no centro de seu argumento, o caminho de crítica exposto por Roswitha Scholz (2016) que move uma “contradição em processo” e baseia-se na crítica do valor-dissociação, interessa muito pela maneira com que se defronta com a discussão sobre a acumulação primitiva. Tal discussão foi revigorada após o crash financeiro mundial de 2008, como “dinâmica essencial do capitalismo”, tal qual uma infinita apropriação e exploração de um "exterior para continuar a existir”. Nesse acumular sobre um exterior, um out-group, ou uma minoria é que Scholz critica a visão ainda apegada à luta de classes ou a uma concepção "operaistafeminista”, visão que ao mesmo tempo negligencia as guerras civis mundias contemporâneas:

Trata-se de uma reestruturação no interior da socialização patriarcal capitalista que, após a fase
fordista do "mecanismo de compensação relativa”, anuncia agora o fim do capitalismo. Os actuais
movimentos de refugiados falam aqui uma linguagem clara. E assim o trabalhador subcontratado /
trabalhador migrante / refugiado, explorado de facto de uma maneira nova e precário, não é
porventura uma nova versão de trabalhador/proletário, mas a expressão do seu tornar-se obsoleto;
uma via de exploração de tipo novo, que a contradição em processo assume por agora na sua
forma de desenvolvimento, numa determinada fase da decadência do capitalismo.
(SCHOLZ,2016)

A resolução de acumulação através dessa “exploração de novo tipo” a Roswitha não desloca a crise para outros locais, como para Harvey ao pensar o ajuste espacial ou mesmo na "Geografia disso tudo" que entende a crise local como global, mas sim sinaliza o esgotamento do capitalismo. A desoneração do Estado em tempos de reorganização dos capitais (produtivos e financeiros), 
tempos de crise, faz com que os serviços voltados para a reprodução da população sofram precarização, assim, há uma espécie de repasse desses custos para a força de trabalho. Esse ponto é entendido como "novo impulso de acumulação", talvez nesse ponto exista similaridade entre Federici, criticada por Scholz, e a acumulação por expropriação/espoliação de Harvey. Nem mais produção de materialidade, nem “exploração de novo tipo" podem reverter a queda tendencial da taxa de lucro da decandência do capitalismo e o que se acumula é barbárie.

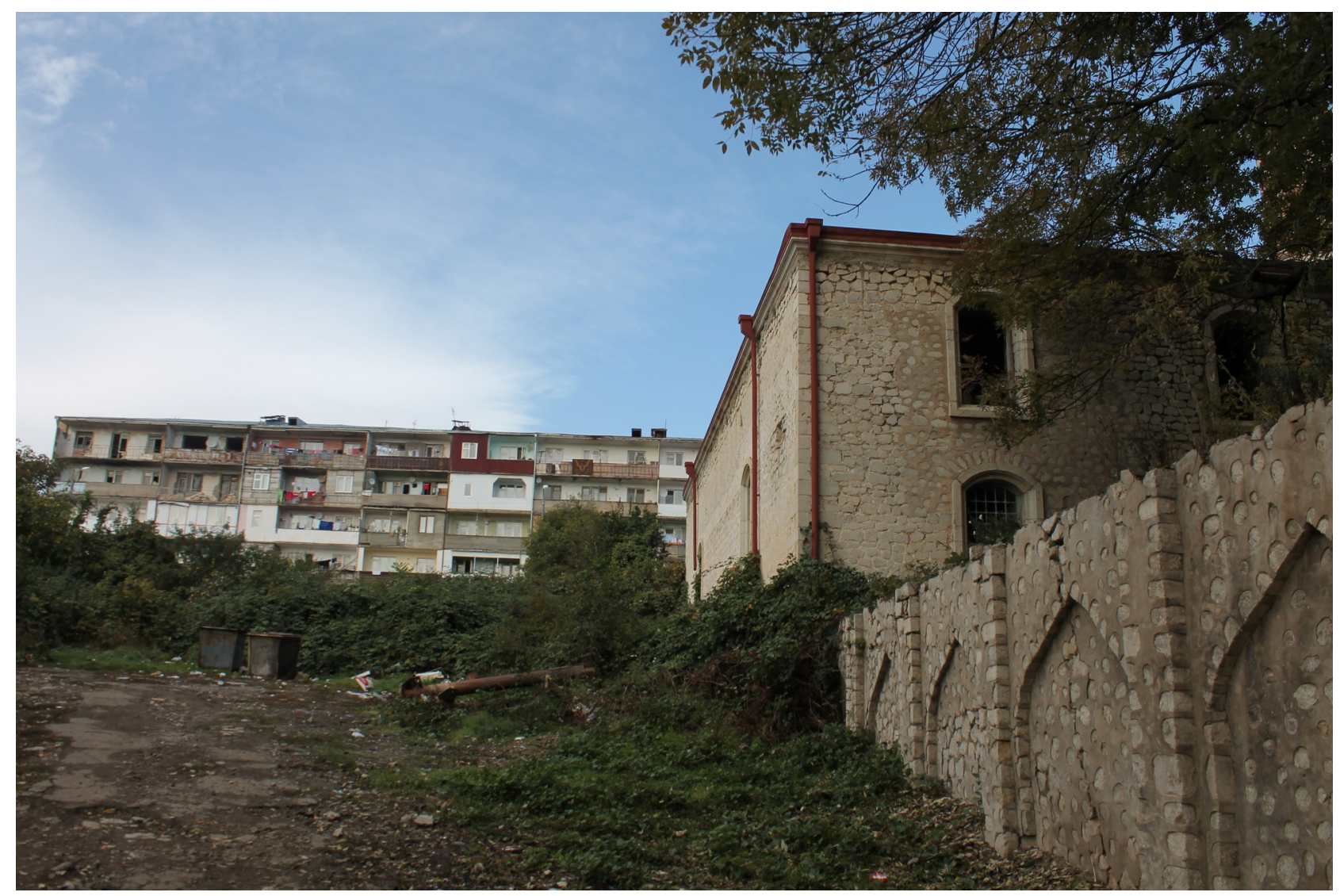

Foto 11 - Em Shushi conjunto habitacional do tempo soviético ao fundo e mesquita que fora utilizada por azeris hoje está desativada. Artur Attarian Cardoso Camarero em 14/10/2013

Fala do representante do Presidente de Artsakh em Stepanakert:

O país não é reconhecido e o fim da guerra não é pré-requisito para o “desenvolvimento econômico”. Mão-de-obra barata, país seguro, incentivos fiscais são os atrativos oferecido por um Estado querendo se estabelecer, bem como taxas de homicídio baixa (sem contar a guerra, é claro). Atualmente há companhias suíças, americanas, canadenses e russas trabalhando aqui com 
mineração. “Temos possibilidade de produzir produtos ecologicamente corretos”, nos disse o palestrante que admitiu a possível venda de água no futuro, especialmente ao Irã. "Se você pensar ninguém é independente, todos os países são interdependentes” para justificar a busca por não isolamento, mas com a ressalva de que interdependência, ao palestrante, não significa transformar Artsakh em uma colônia ${ }^{102}$.

As três primeiras fontes de capitais dentro da República de Nagorno-Karabakh, que é o território de Artsakh para os armênios, chegam, respectivamente, da Armênia, da diáspora como um todo e da diáspora americana. Hoje são auto-suficientes em energia elétrica e começam a exportar, “mas pensamos no futuro porque com maior população não seremos auto-suficientes”. Trouxe também à conversa a comparação com o Estado de Israel onde palestinos vivem em suas terras, mas sem seu Estado, para dizer que Nagorno-Karabakh foi também subjugada em “seu território”. O complexo de inferioridade dos armênios oriundo de 1915, uma identidade dada pela vitimização, para o representante do Presidente não era edificante. Vizinhos, envolvidos, ao redor, trancafiados entre uma região instável.

- É mais fácil viver na Argentina, Brasil, mas temos que viver aqui porque é nossa missão, disse em tom honrado o representante, ainda que faltasse dizer que a missão é “civilizadora”. O conflito não é produto da Guerra Fria, o conflito foi criado em Viena, Paris. É um conflito global. O conflito de Nagorno-Karabakh é entendido cria da “competição geopolítica”.

Foi necessária a contextualização histórica do período de declínio do Império Otomano em suas perdas territoriais ocorridas no auge da competição inter-imperialista com outros impérios (russo, britânico e francês) antes e durante a Primeira Guerra Mundial. Nesse momento, segundo o representante, a guerra de 1914 apareceu como uma “oportunidade” e o Panturquismo como o verniz ideológico necessário para o desenrolar dos massacres de pretensa homogeinização populacional muçulmana. No entanto, ao falar da rápida formação do Estado nacional do Azerbaijão em 1918 após a dissolução da República Democrática Federativa Transcaucasiana que continha Armênia, Geórgia e Azerbaijão e a consequente anexação à URSS, ficou implícita a falta de crítica do representante acerca dos massacres de homogeinização já que nos disse que as pessoas que formaram o Azerbaijão "não eram etnicamente azeris, havia de tudo”, entre eles turcos xiitas, iranianos e daguestaneses para assim “criar o Estado forçado pela situação geopolítica”. dependência completa de Artsakh para com a Armênia. 


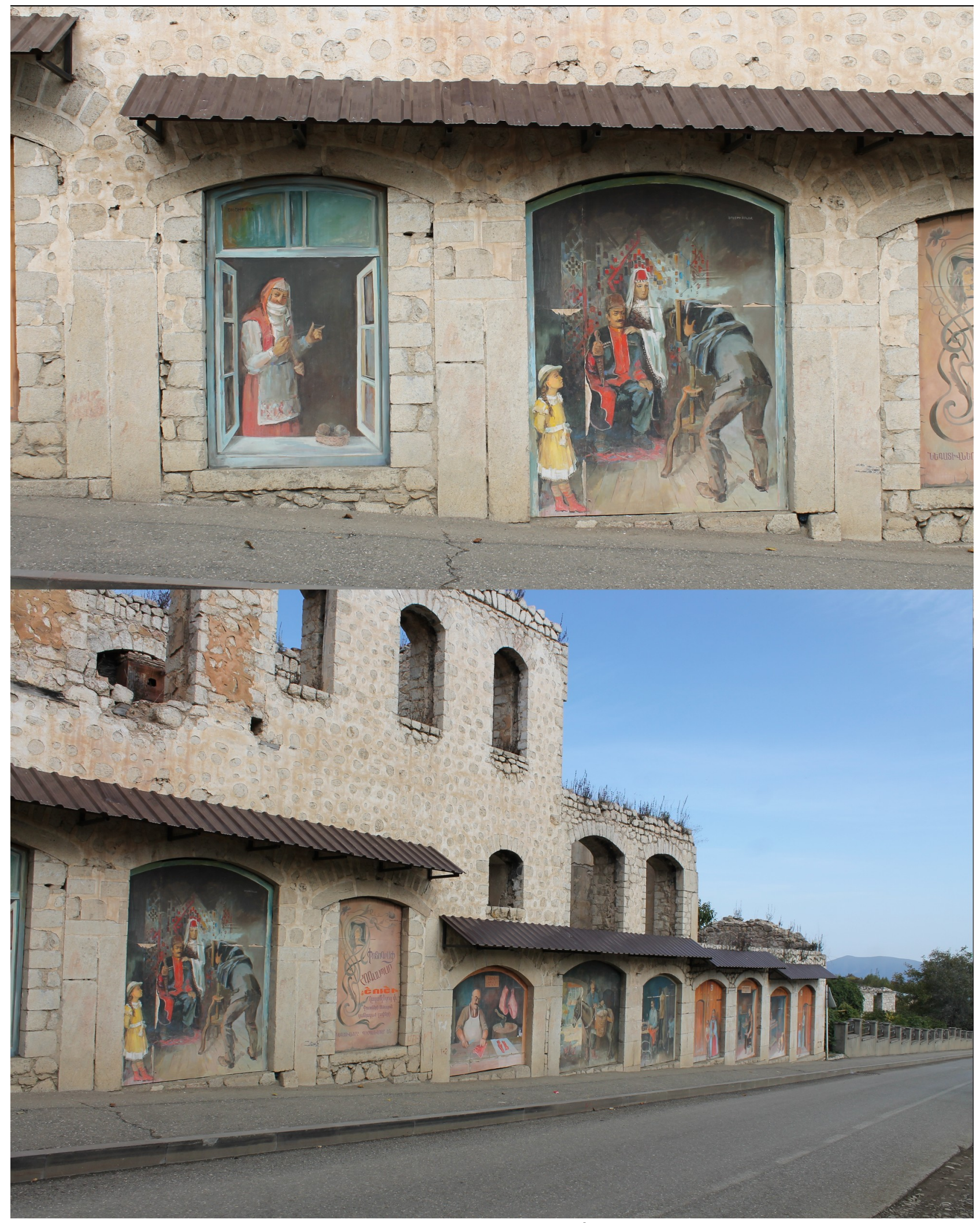

Fotos 12 - Shushi, Nagorno-Karabakh ou Rep. Artsakh ou ainda território do Azerbaijão. Na cidade ocorreu uma “ocupação artística” nos últimos anos com intuito de, por assim dizer, "reanimar" culturalmente a mesma. Pinturas em um prédio vazio e bombardeado mostram as profissões e cenas para representar a vida cotidiana de outrora. Artur Attarian Cardoso Camarero em 14/10/2016 
- Por que a guerra com ISIS segue? Indagou o representante do Presidente em tom retórico para em seguida emendar:

- Porque é lucrativo e muitos fecham os olhos para isso. Se criarmos as condições para que aqui seja assim (lucrativo) poderemos ser reconhecidos (enquanto país). Não é um problema no Ocidente reconhecer novos países, mas eles precisam ser rentáveis.

Depois dessa acertada afirmação sobre a rentabilidade veio a convocação para o nacional: “você precisa sentir algum reconhecimento para estar aqui, pagar por nossas vítimas, desenvolver nosso país e o sentimento de nacionalidade. Não é o paraíso, é a selva”.

Museu da guerra em Stepanakert

Adentramos o "Museu do Soldado Caído” por um estreito corredor preenchido de retratos de vítimas da guerra e outros tantos momentos de conflito, além de medalhas de honra e outros tantos objetos pessoais dos caídos, fomos guiados pela mãe de um soldado armênio falecido no conflito de Nagorno-Karabakh, uma das idealizadoras do local. Além da entrada havia outras duas salas igualmente decoradas com o horror e honra. Ao final da primeira sala uma bandeira do Azerbaijão em frangalhos junto às letras em cirílico que no tempo da ocupação azeri formavam Shushi. A bandeira chegou àquele estado por conta dos odiosos visitantes que ao longo de anos pisam sobre ela, provando sua armenidade. Muitos voluntários não tiveram dúvida e quiseram logo demonstrar seu simbólico apoio pisando e, sem notar, logo perpetraram mais sentimento de ódio alimentado por uma narrativa unilateral.

Nunca é demais lembrar da sétima tese sobre o conceito de história de Walter Benjamin a nos dizer que "nunca houve um monumento da cultura que não fosse também um monumento da barbárie. E, assim como a cultura não é isenta de barbárie, não o é tampouco, o processo de transmissão da cultura” (1994: 255). 


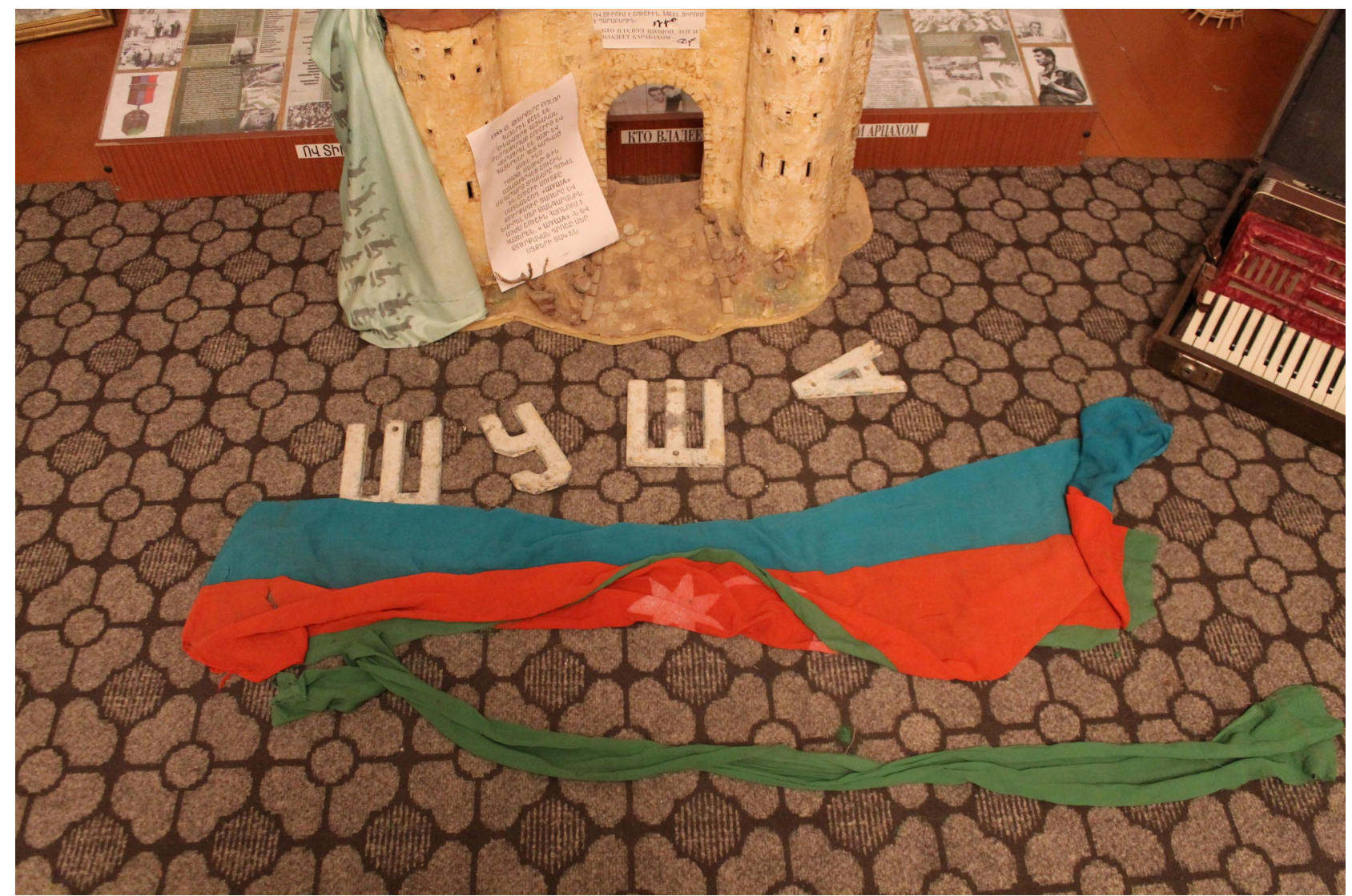

Foto 13 - Bandeira do Azerbaijão pisoteada no Museu do Soldado Caído em Stepanakert. Marina T. Machado em $14 / 10 / 2016$

15 de outubro

Amanhece chovendo em Shushi e não há água para nos banharmos nos banheiros. No caminho para Tigranakert vimos caminhões verdes da marca russa KAMAZ e poucos carros na outra direção, estávamos na borda de Artsakh, a terra nessas alturas é de um marrom escuro e avermelhado, parece e dizem ser fértil. Muitas casinhas de pedra destruídas pelo caminho. Na entrada de Tigranakert, um grande forte de pedras e um pequeno mercado. Encruzilhada da antiga Armênia, o forte foi construído por Tigran, o Grande, no século I a.C. e possuía quatro fortes. Aqui estamos para plantar árvores, coisa de voluntário. Um voluntário americano entre nós, daqueles mais orgulhosos da armenidade, carregava a bandeira Dashnak (F.R.A.) e deixava seu tocador de música portátil tocando o pop de e sobre Artsakh.

Almoçamos em uma Base Militar, tida como a melhor da região, que foi fundada em 1993 em um prédio com aparência de velho. Estávamos bem próximos da zona tampão e antes passamos por uma exibição conjuntural sobre as bases e a guerra em uma sala com um fardado que nos apresentou o complexo militar e que nos contou que em abril de 2016 o exército armênio derrubou dois tanques e capturaram outros. Estávamos em uma sala com mapa/croqui em relevo a mostrar a distribuição das vilas e geomorfologia da área que a base é responsável. O mapa, que nos deu a 
impressão de uma tecnologia analógica antiga, mostra a fronteira e há bastante representação do lado do Azerbaijão. No man’s land, trenches, buffer zone. A cidade de Ardan que é a maior do pedaço está em grande parte destruída. Nas montanhas ao norte fica a Brigada dos Antílopes onde se faz necessário um carregamento quinzenal.

O cessar-fogo foi violado há aproximadamente duas horas, dois dias atrás um soldado armênio morreu, desde abril já morreram ao menos 25 homens. Nos quatro dias de abril usaram armas mais pesadas, o que é considerado invasão. A maior parte do tempo é dedicada ao treinamento. Treino físico, café, três horas de treino, almoço, aula teórica, tempo livre, jantar e tempo livre. Há livros de registro em cada base para que sejam anotados os tiros, descargas e “só há respostas quando se sabe que o perigo vai além da simples provocação ou amedrontamento”. Como reiteraram outras pessoas e especialistas, a Armênia está em posição de defesa em Artsakh. Os homes que terminaram o serviço continuam como reservas até os 50 anos de idade e de tempos em tempos fazem exercícios para retomar o treinamento. Em caso de qualquer necessidade esses reservas são comunicados para realizar operações em lugares específicos. Se for armênio no exterior e voltar ao país até os 27 anos, o serviço de dois anos também é obrigatório.

As mulheres que trabalham nas bases são enfermeiras e algumas no serviço especial como atiradoras de elite, mas na fronteira em geral não há mulheres. Há três mulheres graduadas na posição de tenente nos últimos anos.

Perguntados sobre a origem do dinheiro e armas que abastecem o exército, os homens com sorriso de canto de boca desconversaram e disseram que este era um assunto do Ministério da Defesa. Após a compra de aviões não tripulados hi-tech russos por parte da Armênia que foram orgulhosamente exibidos na festa de independência da Armênia no centro de Yerevan em 25 de setembro, 25 anos pós-colapso da U.R.S.S, os azeris não divulgam mais e não fazem mais alarde sobre seus planos, materiais e estratégias de guerra. Caminhando em Yerevan vi paradas militares na semana de comemoração da Independência, mas o dia da cena política e do patriarcado na Hrapetutyun hraparak (Praça da República na capital) assisti na TV junto ao meu vizinho que serviu o exército ao norte e não no conflito de Karabakh. Ele estava esperançoso com a nova aquisição do exército armênio que deu o que falar e é comentado por Porto em um artigo de 2017.

Em Stepanakert os voluntários participaram de uma ação chamada winemob, o intuito era provar a hospitalidade do povo de Artsakh e sair de porta em porta, oferecer um vinho nas casas na expectativa de entrar e conversar com moradores. O grupo em que estava foi logo capturado por um senhor que nos levou ao apartamento de sua família, pessoas vindas de Baku. O pŕedio nos padrões 
soviéticos e sua área comum, elevador, escadas e corredores não conhece reformas há um bom tempo, mas o interior do apartamento que entramos está, como em muitos casos na Armênia, todo reformado e modernizado e aqui se inverte a popular expressão: “por dentro bela viola, por fora pão bolorento”. Nosso anfitrião é jornalista e nas primeiras conversas logo chamou sua esposa, que é professora, de chauvinista por não tolerar turcos. A filha do casal que já é mãe também “não passa pano” para turcos e azeris e diz que dali eles não sairão mesmo se os conflitos se intensificarem.

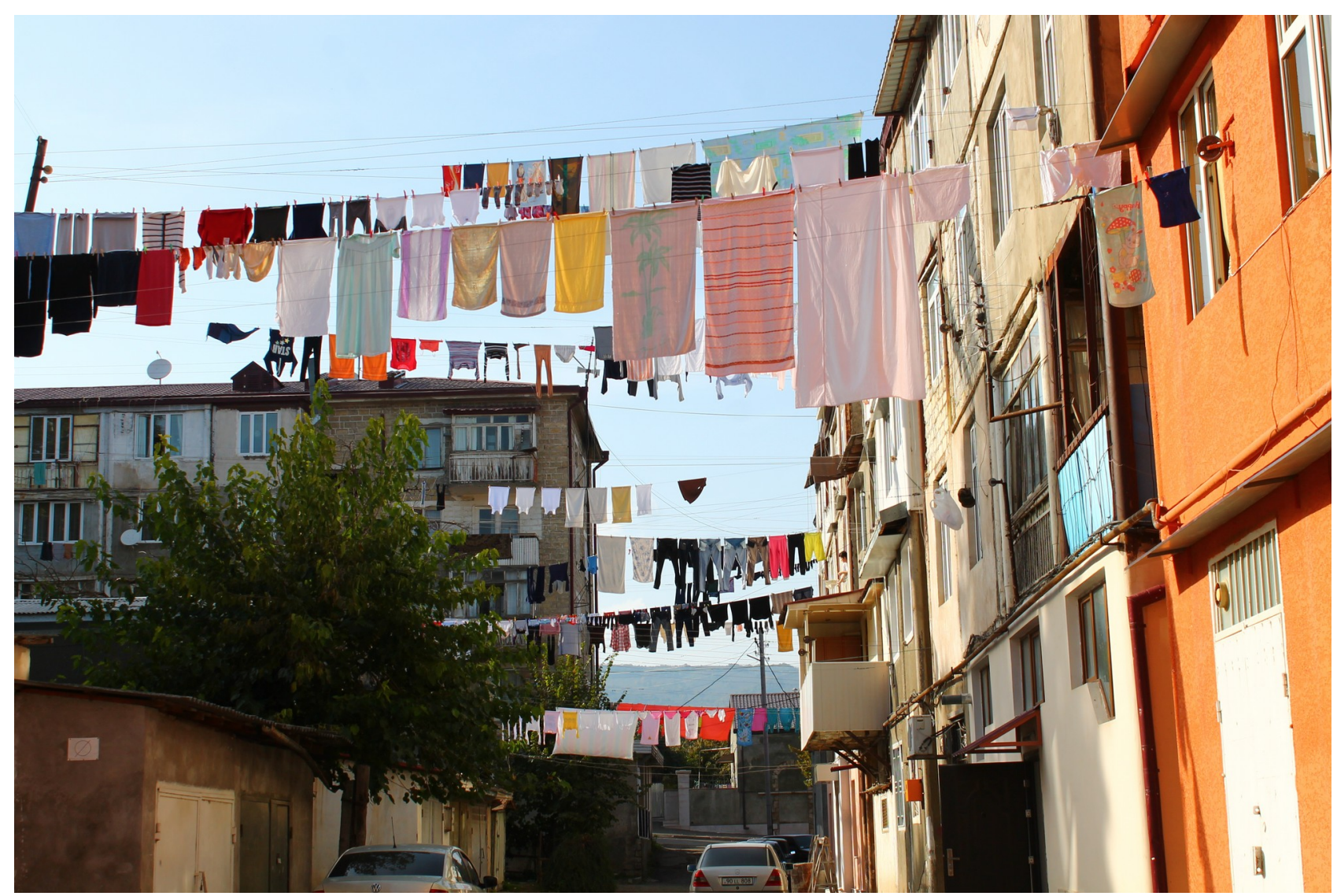

Foto 14 - Coloridos varais entre prédios em Stepanakert. Marina T. Machado em 15/10/2016. 


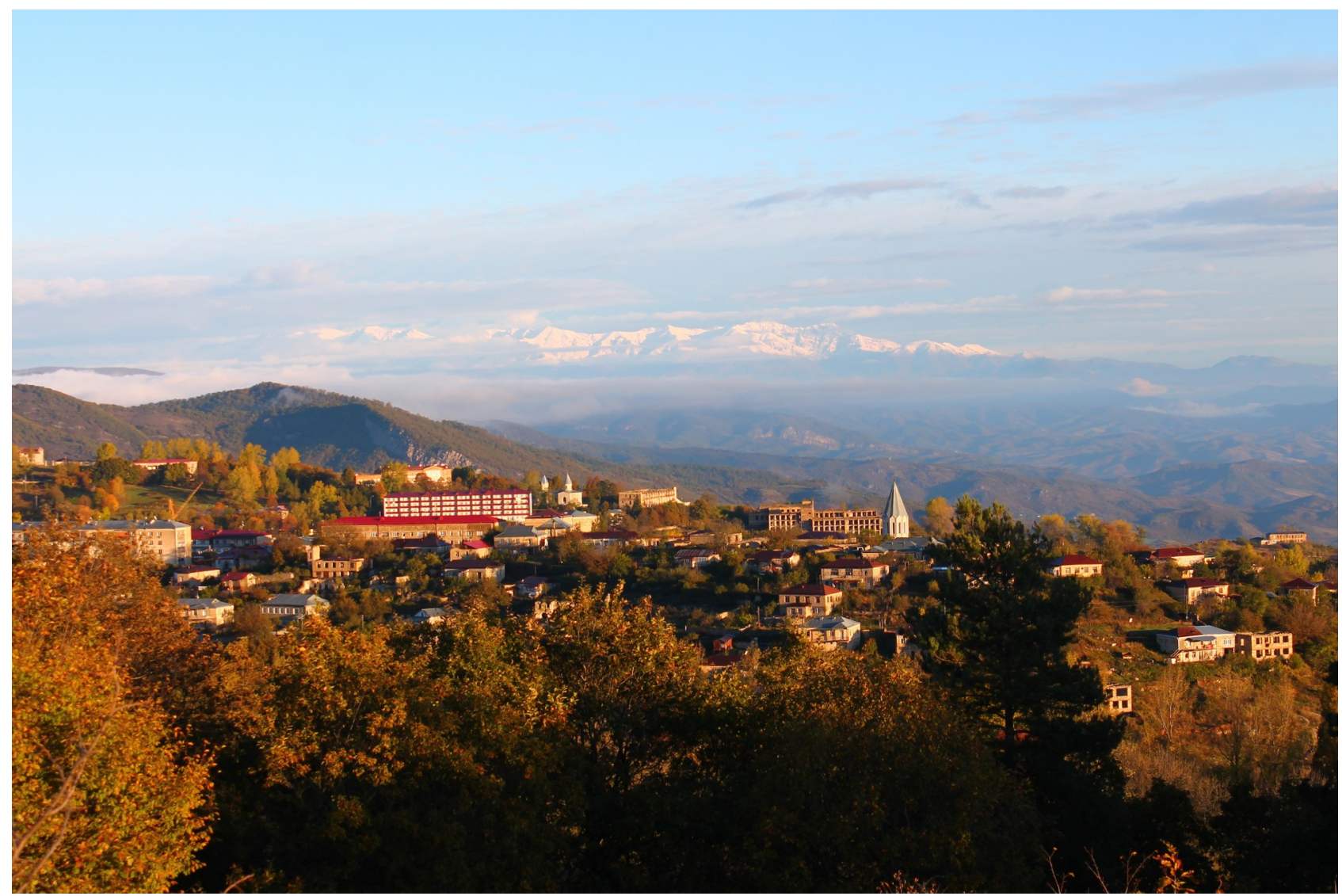

Foto 15 - Caminhada nas montanhas e a vista de Shushi. Foi por esse lado norte de Shushi a decisiva e surpreendente invasão, tomada e (re)ocupação também de Stepanakert em 1992. Artur A. C. Camarero em 16/10/2016.

Antes de pegarmos a estrada sentido Yerevan, fomos para dentro de um ramo de estrada que sai junto ao ponto de checagem na assim chamada fronteira entre Armênia e Artsakh - de fato há controle de passaportes nesta linha - para visitar a vila de Herik (com a ambiguidade da palavra significar 'suficiente') subimos montanhas até onde o ônibus aguentou. Na primeira parada conversamos com um casal de americanos, de origem armênia, captador de recursos que depois de formados em Los Angeles decidiram viver nessa remota porção do globo terrestre. Um mercadinho na estrada, pés de maconha que fingiam passar desapercebidos e de carona com uma espécie de kombi soviética, que serve de transporte e ambulância a quem vive montanha à cima, seguimos viagem. Cruzamos com uma ponte sendo construída, sinal de confiança a ponto de modernizar o território não reconhecido internacionalmente? Tração trazeira é só o que sobe ladeira e assim embarcaram vários viajantes voluntários na estrada de terra.

A vila tem sido aos poucos (re)ocupada recentemente, ali viviam azeris antes da guerra e armênios narrando, otra vez más, tempos imemoriais; mas durante a guerra de Nagorno-Karabakh, que acabou mas não terminou, Herik ficou vazia. Hoje vivem 62 pessoas ali e esse tal repovoamento após conflitos aparece na história toda de armênios, turcos, azeris, russos, persas, 
curdos, circassianos, assírios, gregos, albaneses, georgianos e tantas mais nacionalidades e nacionalismos. Por cima das ruínas da guerra são erguidos novos monumentos da cultura apagando a acumulação de barbárie. Nesse aparente recomeçar se entrelaçam capitais da diáspora fundando escola e distribuindo coisas, a duras penas territorializando a armenidade na mobilização de terra, trabalho, capital, teologia sacrificial cristã, cisão do patriarcado e um ethos da guerra tão fresco quanto o ar das altas montanhas.

Para Porto (2017), a Guerra do Karabakh é o renascimento de uma identidade cultural armênia, identidade essa que segue tendo o Genocídio como outro fio condutor de um sentimento de pertencimento a uma comunidade imaginada, especialmente à assim chamada diáspora; no entanto, vale a ressalva de que enquanto ocorrem os conflitos com o Azerbaijão, a exemplo dos quatro dias de abril de 2016, e as famílias e pessoas amigas vivem o cotidiano à espera da volta de seus homens, a diáspora segue focada em memória e reparação do Genocídio. O trabalho de Porto aponta para isso por alguns caminhos para pensar, a exemplo da perspectiva de Roland Barthes de que o mito se funda na natureza e suprime a dialética da história, “narrativa mítica” e o mito fundador da diáspora ser o Genocídio Armênio ${ }^{103}$, e nossas conversas aqui relatadas muitas vezes nos deparam com esse descompasso na representação de uma identidade nacional armênia dentro e fora da Armênia.

Visitamos uma igreja incrustrada na pedra, um voluntário americano achou ter visto inscrições pagãs, não parecia. Nas pedras vê-se também janelas e portas das casas vazias e casas repovoadas. Havia um mal-estar entre alguns de nós a visitar um lugar de vida tão dura ao mesmo tempo em que éramos tratados tão bem. Nos dividimos em alguns grupos para almoçar na casa dos habitantes da vila, estávamos entre russos, brasileiros, argentinos e ucranianos e adentramos uma casa de dois cômodos, chão de madeira e lareira entre o quarto de todos e a sala-cozinha onde estava posta uma mesa sem espaço para mais nada. Aquilo me fez lembrar do provocativo filme “Feios, sujos e malvados” de Ettore Scola. Eram pratos e mais pratos, sucos, refrigerante, doces e salgados, dolmá de repolho, arroz especial, carne de carneiro, coxas de frango, bolo de chocolate, bombons e balas. A mãe de sete esperando o oitavo cozinhou tudo, mas quem sentou à mesa foi o patriarca, naturalmente. O clima ficou estranho porque enquanto o russo era a língua oficial do almoço, entre os sulamericanos se falava um espanhol constrangidamente nervoso com aquela situação até que a certa altura fomos indagados, em inglês, por uma moça russa se estava tudo bem, se havia algum problema ou coisa parecida e, pisando em ovos, respodemos algo sobre a hospitalidade que era tão grande quando julgávamos-nos não merecedores. Mas era muito mais do

103 Assunto que já foi criticado na primeira parte deste texto através do conceito de mobilidade do trabalho (Gaudemar, 1977) pela concepção de que força de trabalho constitui a mobilidade no mercado mundial em guerras constantes e não a armenidade enquanto fenômeno cultural pura e simplesmente. 
que isso, naturalmente, e a moça russa a insistir para relaxarmos, pois ela nos dizia que isso era coisa de família armênia, “na sua família não é assim?” Ajudar a limpar a mesa nem pensar, naturalmente.

Mais tarde e antes de voltarmos rumo à capital, visitamos a primeira escola de Herik recém construída e que leva o nome de um jovem que ali vivia e foi morto aos 19 anos no front da Guerra de Karabakh. Salas novas, alguns computadores, dinheiro da diáspora e da Armênia, porém o que mais espantou foi a aula militar preparatória destinada a jovens desde os 14 anos. O professor da disciplina estava fardado e nos disse que orienta os alunos sobre como construir bunkers, estratégias e manuseio de armas, que ficam trancadas em uma sala ao lado de onde ocorrem as aulas.

No intuito de amenizar e integrar os voluntários internacionais com os habitantes da pequena vila foi organizada uma brincadeira que lembrava o tunel das quadrilhas da festa de São João, mas com a peculiaridade de que a pessoa que entra no túnel "rouba” um dos parceiros de quem forma a parte superior do túnel e assim, a pessoa sem parceiro vai pro fim da fila para entrar novamente no túnel reconfigurado e "roubar" alguma pessoa para ser seu par e tudo recomeçar. Por fim, depois dessa confraternização veio a volta e no meio do caminho até o asfalto tinha um rebanho de ovelhas sendo tocado por um morador local. Ao ver a cena, um funcionário do programa de voluntários fez o infeliz e, no mínimo chauvinista, comentário: “olhem, as tropas azeris” e muitos otários voluntários caíram na risada. Animalizar o inimigo historicamente tem sido usado como parte de agitação do ódio para a guerra, com o intuito de minorizar um outro, tornando-o passível de extermínio. Dr. Nazim, o médico ideólogo do panturquismo do Comitê União e Progresso, chamou os armênios de praga gangrenosa em uma convenção como vimos no artigo de Spinelli (2011). Mais adiante abordaremos como Adorno entende a comparação dos out-group a animais como um dos “dispositivos prediletos dos agitadores fascistas”. Dadrian aponta para os rótulos que foram empregados às minorias diante da dominação otomana que para além do infiel (giavur) eram utilizados para referir-se ao “inferior, desprezível e vulnerável status dos não-muçulmanos. Deve-se fazer referência a outro rótulo, um corolário de infiel, nomeadamente, raja, que deriva do termo gado” (2017 [1979]: 18). Para o autor, nas entrelinhas de rotulações como essas perpetradas por um grupo dominante sobre uma minoria pode-se cristalizar um status entre estes grupos ao ponto deste passar a ser entendido como natural, de maneira a desenvolver padrões nos quais os grupos antagonistas tornam-se aptos a "antecipar corretamente expectativas mútuas associadas ao respectivo status” (ibidem). O feitiço volta-se contra o feiticeiro, no passado vítima, no presente perpetrador. O ethos da guerra em seus rótulos animalizantes expõe tanto o horror quanto a honra como dois lados da mesma moeda nacional. 


\section{9) Kapan, 13 de novembro de 2016}

Em meio a uma excursão para a região de Syunik, ao sul da Armênia, próximo à fronteira com Irã, passamos a primeira noite e parte do dia de hoje em Meghri, cidade rodeada por montanhas e, como sempre, cheia de histórias. Por conta de sua proximidade com o território iraniano, a cidade esteve sob domínio persa até a Guerra russo-persa em 1827 quando os armênios da banda oriental do Cáucaso passaram a integrar o Império Russo, depois de quatro séculos de dominação persa. A cidade é um baita meio de caminho, integrando a famosa rota da seda que da Pérsia chegava até o Mar Negro. É meio de caminho também entre Turquia e Azerbaijão, pois é vizinha do exclave de Nakhijevan e da conflituosa região de Artsakh. Durante a guerra de NagarnoKarabakh (1988-94) foram rompidos, cortados, destruídos os trilhos de trem que ligavam o atual exclave de Nakhijevan com a cidade de Meghri e o território contíguo do Azerbaijão. Pudemos ver tudo isso.

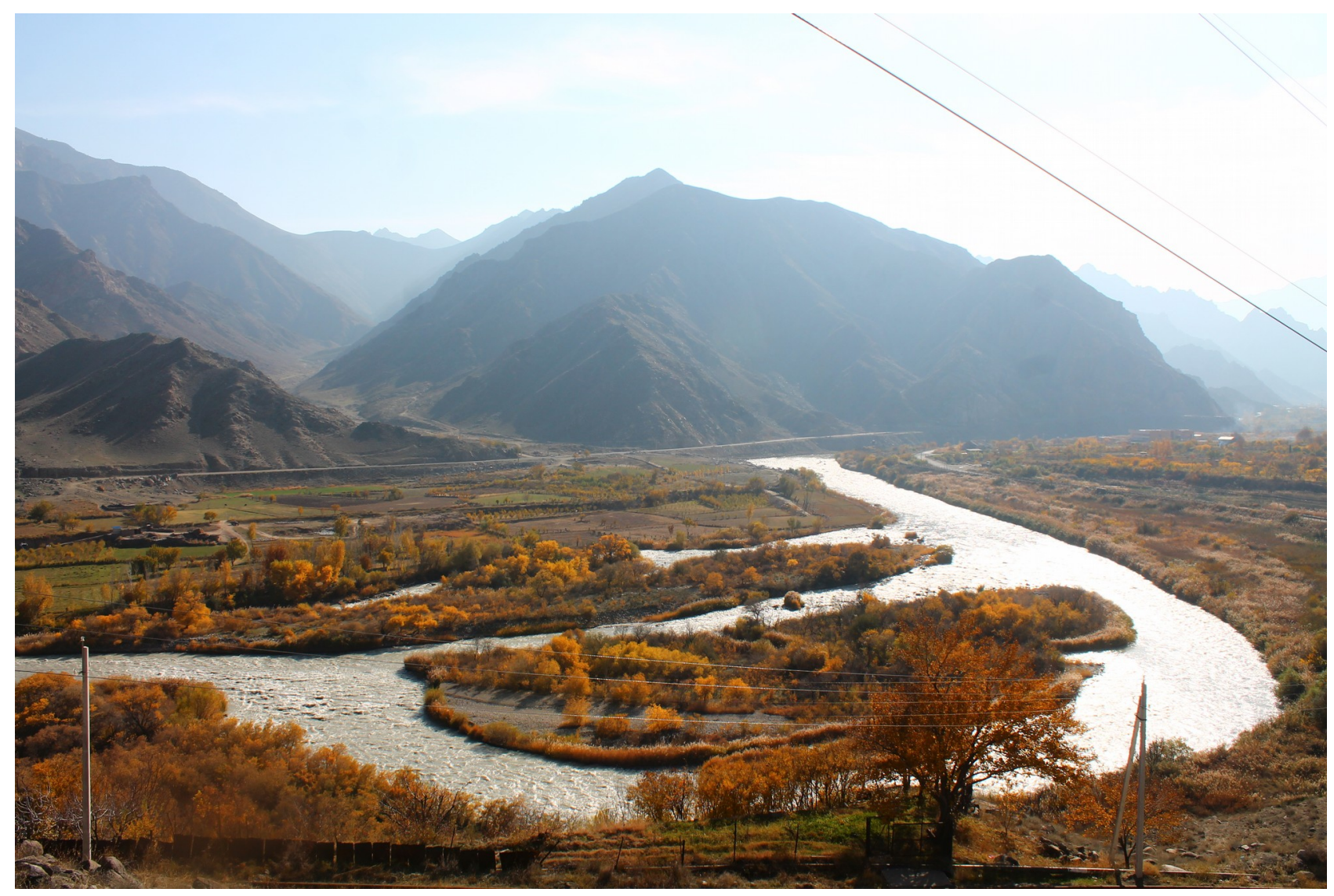

Foto 16 - À beira do Rio Araks que chega na fronteira já bastante assoreado, tendo sua água utilizada em território turco à montante. Do lado armênio da fronteira há atividade de mineração, criação de ovelhas, produção de frutas, do lado iraniano pouco se sabe. Artur A. C. Camarero em 13/11/2016 
Fato é que, dentre as quatro fronteiras armênias, só essa ao sul e a com a Geórgia ao norte seguem abertas. Houve uma tentativa de reabrir a fronteira entre Armênia e Turquia há pouco mais de nove anos atrás; ao que consta o acordo andou até o ponto em que a Turquia propôs a condicional de que a Armênia deveria reconhecer Nagorno-Karabakh, aos armênios Artsakh, como parte integrante do território azeri, o que obviamente não foi aceito pelo governo armênio na ocasião. No lado leste, a guerra de baixa intensidade mantém alta tensão.

A situação da Armênia em termos de trocas comerciais por terra, escoamento de mercadorias, dependência energética é tenebrosa e, por essas e outras, a relação com o Irã é vista como estratégia, ainda que complexa. A Armênia passou, nos últimos anos, a negociar gasolina e gás natural com o vizinho ao sul, o que chamou a atenção da velha parceira de tempos soviéticos, a Rússia, fazendo com que esta impusesse limites de volume a serem comercializados pelo tamanho do diâmetro do tubo de gás canalizado. Curiosamente, esse canal que entra pela fronteira sul é destinado à capital Yerevan e não há saídas para o abastecimento de outras cidades, inclusive Meghri que se localiza a oito quilômetros da fronteira. Essa fronteira era o limite territorial soviético e, por conta disso, segue delimitada por muros e arames farpados, embora o Irã seja o vizinho armênio com relações aparentemente mais amigáveis e em expansão; hoje as mercadorias armênias com maior presença no mercado iraniano são carnes: boi e ovelha. Na fronteira oposta, com a Geórgia, a situação é distinta. Se diz que no século XIX havia maioria armênia na capital Tblisi, muitos comércios, igrejas armênias e por aí vai. Mas hoje parece que essa influência não apenas é menor como desenvolveu-se, ao longo do século XX, um nacionalismo georgiano que em grande parte pauta-se em diferenciação frente ao nacionalismo armênio e seus símbolos, chegando ao ponto, inclusive, de haver manifestações anti-armênias. A versão aqui relatada baseia-se em um panorama conjuntural feito por descendente de armênios nascido em Los Angeles que reside há mais de dez anos em Yerevan. A versão armênia parece sempre enfatizar a vitimização de seu povo, ainda que o informante ao final de sua fala tenha ressaltado que a Armênia precisa parar de lamentar, expandir ao máximo seus parceiros comerciais para “andar com as próprias pernas”. O cenário é realmente difícil para a Armênia em suas fronteiras conflituosas, relações marcadas por racismo e diferenciação nacionalista por todos os lados, fato que se agrava no conflito religioso entre cristianismo pioneiro orgulhoso e os vizinhos xiitas azeris e turcos de maioria sunita.

Além do mais, o que se vê longe da capital é um território pouco habitado e dotado de tecnologia ultrapassada e infra estrutura sem renovação desde os tempos do colapso soviético, prova disso são os prédios daquela era. Desta vez podemos usar um ditado brasileiro invertido: “por dentro bela viola, por fora pão bolorento” devido às condições precárias sem ou com elevadores, alvenaria caindo, etc. Porém, no espaço privado do lar é possível ver apartamentos completamente 
reformados e dotados de eletrodomésticos de modelos recentíssimos. Aquilo que é sacrossanto aos patrimonialistas, isto é, a fachada dos prédios, na Armênia é mundano e passível de transformações a qualquer momento. Esse estado de coisas, por outro lado, pode vir a ser uma “oportunidade” para capitais ociosos, especialmente da diáspora estadunidense em busca de algo como um "ajuste espacial” (Harvey), ou uma busca de valorização pelo imobiliário através da tal "gentrificação” (Smith), mas o mercado interno não parece ter fome o bastante para que esse seja um negócio rentável para além do “oásis” da diáspora. Quando estávamos ouvindo Kevork, que nos guiou ao forte de Davit Bek em Meghri, falar sobre a história do lugar, sobre as dominações persa e russa, ouvimos também, ao final de sua fala, uma convocação aos jovens da diáspora para que venham à Armênia para ficar, fazer investimentos, negócios, se casar com locais, trazer familiares e colocar nomes armênios em seus filhos. Esse tipo de clamor é apoiado pelo programa de voluntariado e já havia ocorrido em outras oportunidades, mas ainda não havia assumido uma forma assim tão explícita.

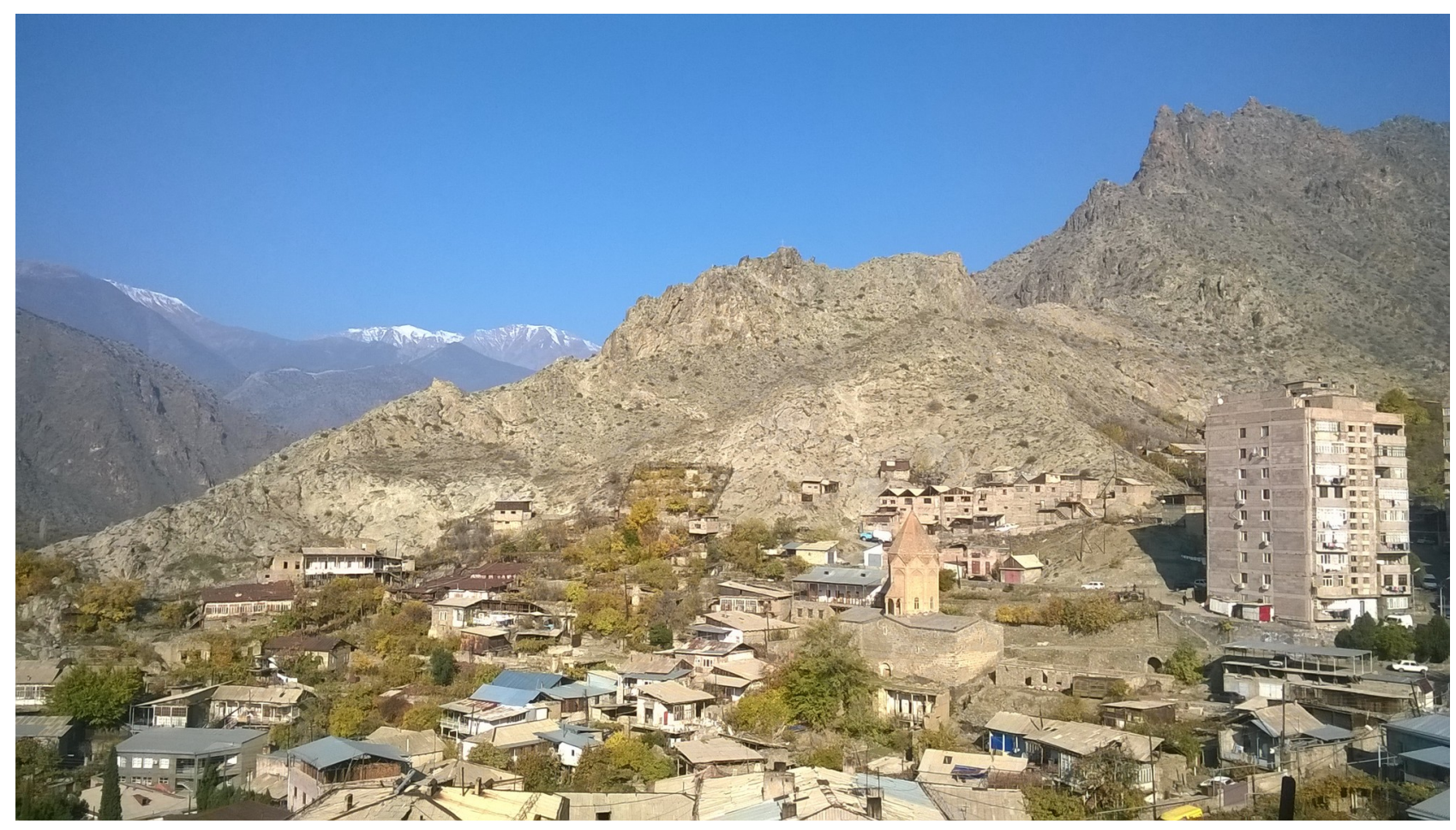

Foto 17 - Vista de Meghri a partir do forte Davit Bek, cidade-encruzilhada dos impérios russo e persa no passado e hoje barreira da comunicação entre o exclave azeri de Nakhijevan e o resto do território do Azerbaijão. Artur A. C. Camarero em 13/11/2016

Já em Kapan fomos recebidos e encaminhados para as respectivas casas de locais na sede do partido Dashnak, ou, Federação Revolucionária Armênia, o que soou um tanto estranho. Na parede a bandeira de Artsakh, do partido ao centro e da Armênia à direita. Vim junto com um voluntário alemão de Frankfurt, para a casa de um senhor que é membro do partido desde o colapso. Meu 
armênio é melhor do que o do jovem alemão e isso me obrigou a tentar fazer a ponte entre eles, ponte essa que funcionou melhor do que imaginava, mas, obviamente, não deu conta do vocabulário. Longe disso. Pouco antes de nos saudar com um "bahri gisher” (boa noite), o senhor nos mostrou um vídeo, que fora publicado dois dias antes, da juventude Dashnak em Los Angeles ocupando uma aula na Cal State University, Northridge. Os jovens que pertencem a três organizações armênias da Califórina: Associação de estudantes armênios, A sororidade armênia (Alpha Gamma Alpha) e A fraternidade armênia (Alpha Epsilon Ômega) fizeram um piquete sentados próximos à lousa paralisando a fala do professor convidado G. Gawrych sobre a história da moderna Turquia, mais especificmante Mustafá Kemal, o pai dos turcos. O grupo entrou na sala entoando "shame on you, Atatürk" e o tempo fechou, por pouco não saiu pancadaria até que os estudantes sentaram no chão e a aula foi interrompida. Depois disso, o grupo deixou vários panfletos que argumentavam pela continuidade do genocídio através da instituição da política de negacionismo durante a gestão de Kemal na década 1920 e 1930. 


\subsection{0) Massacre da modernização}

Adorno, em seu escrito sociológico denominado “Individuo y organización”, apresenta a ideia da organização como união local administrativa criada e dirigida, sendo, com isso, um fenômeno social. A noção de organização, além disso, é relativa à racionalidade orientada a certos fins: alcançar determinados resultados a partir do consumo mínimo de forças. Emergem dessa concepção noções advindas das ciências biológicas como órgão e noções mecânicas como ferramenta. O indivíduo frente à organização é uma das partes de um todo funcional mediatizado; uma peça, uma ferramenta, um órgão; e a organização, por sua vez, frente ao indivíduo também estabelece uma relação alheia, rígida, violentamente exterior, dotada de inescapável objetividade. A forma da organização, dessa maneira, confunde-se com seu conteúdo, nas palavras do autor: “en la organización las relaciones humanas están mediadas por el objetivo, no son inmediatas”104 . É certo que o argumento que Adorno persegue preocupa-se muito mais com as formas organizativas sob a égide do capital que, historicamente, se enrijeceram no seio do totalitarismo europeu; formas que alienaram e coisificaram os indivíduos que, enquanto partes, constituem organizações e instituições. A racionalidade objetiva da organização totalitária “devora todo lo que le resulta alcanzable, persiegue en ello la unificación técnica, pero también el próprio poder"105. Na arbitrariedade seletiva da organização totalitária não se admite o diferente de sua racionalidade objetiva, violência aterrorizante que regula e reduz à sua forma sob a aparência da neutralidade organizativa. O mundo administrado é o terror do mercado legalizado/juridificado pelo Estado.

As formas de autoconsciência de si ocorrem à pessoa que, ao passar por um processo de identificação, individualiza-se, mas, contraditoriamente, passa a integrar algum grupo em meio à sociedade de massas. É o out group e in group que forjam a identidade em tempos de conflito, através da diferença, pelo estranhamento, pela intolerância, pelo medo concorrencial: burguesa, reativa, violenta, uma força modernizadora apoiada em representações regredidas do arcaico e disposta a massacres de reorganização monopolista. Momentos de autonomização em que a tecnologia, o aparato, aplica-se na organização e no controle burocrático da sociedade, como foi na guerra inter-imperialista de 1914 que deu fim a certo tipo de impérios multi-étnicos contínuos territorialmente. A guerra é, nas entrelinhas da modernização, o momento de racionalização produtiva radical através da “mobilização geral”(Gaudemar, 1981).

104ADORNO, Theodor. Individuo y organización. In: Escritos sociológicos I - Obra completa, 8. Traducción: Agustín González Ruiz. p. 414.

105Ibid., p. 413. 
O fantoche vestido à turca que Benjamin evoca na abertura de suas teses sobre o conceito de história, pode ser interpretado como o sujeito automático do valor envolto em sua teologia.

Conhecemos a história de um autômato construído de tal modo que podia responder a cada lance de um jogador de xadrez com um contralance, que lhe assegurava a vitória. Um fantoche vestido à turca, com um narguilé na boca, sentava-se diante do tabuleiro, colocado numa grande mesa. Um sistema de espelhos criava a ilusão de que a mesa era totalmente visível, em todos os seus pormenores. Na realidade, um anão corcunda se escondia nela, um mestre no xadrez, que dirigia com cordéis a mão do fantoche. Podemos imaginar uma contrapartida filosófica desse mecanismo. O fantoche do "materialismo histórico" ganhará sempre. Ele pode enfrentar qualquer desafio, desde que tome a seu serviço a teologia. Hoje, ela é reconhecidamente pequena e feia e não ousa mostrar-se (Benjamin, 1985, p. 222).

Trabalho comandado e a dissociada reprodução se escondem por meio de um jogo (sistema) de espelhos que anima, dá vida e valor ou "valor à vida" a um autômato, um fantoche autosuficiente e tautologicamente sempre disposto a contralances em busca da vitória, a vitória do materialismo histórico para Benjamin. Essa é a vitória da modernização?

De posse dos serviços da teologia do fetichismo da mercadoria, interessa pensar o capitalismo como religião também proposto por Walter Benjamin; o cristianismo e a igualdade fetichista do valor no direito, a necessidade prática de que Marx fala em "sobre a questão judaica” e, para fechar o trio das religiões abrâamicas e as diretrizes religiosas da valorização, qual seriam as contribuições do ponto de vista da formação ético-moral do islamismo desde os estouros da modernidade no Império Otomano?

O argumento desenvolvido por Robert Kurz pode apontar caminhos a respeito do sacrifício invandindo a modernidade ao se transformar na forma reificada do dinheiro com fim-em-si em "O dinheiro sem valor”. Esse argumento se apoia na ideia de “capitalismo como religião” de Benjamin para tentar desdobrar esse “o sacrifício e regresso perverso do arcaico” também nas formas fetichistas de subjetivação contemporânea:

\begin{abstract}
Na realidade, o que agora está em causa é o regresso do arcaico sacrifício humano, mas justamente numa forma reificada. O sacrifício e o auto-sacrifício não só são permanentes e abrangentes, em vez de limitados aos dias de feriado como antes, mas também já não constituem um acto de expiação temporária e parcial, como Benjamin assinalou com perspicácia. Em vez disso, cada acto quoditiano de auto-sacrifício de energia vital abstracta constitui nova e adicional "dívida" até a eternidade, para permitir a acumulação desmedida de "riqueza abstracta" num patamar cada vez mais elevado (Kurz, 2012: 369)
\end{abstract}

A imagem de um anão corcunda escondido, comandando um fantoche à turca é de grande potência simbólica para se pensar as sujeições que a modernidade historicamente foi nos impondo, enquanto sujeitados a um processo voltado ao finalidade da valorização. Adorno nos indica que os 
homens foram convertidos em apêndices da maquinaria ${ }^{106}$ e, anteriormente, Karl Marx expõe brilhantemente esse processo na seção sobre a "produção de mais-valia relativa” d’O Capital. O indivíduo em relação com a sociedade capitalista não é independente; é sim, a mercadoria fantasmagórica que cria valor, que, sozinha, vai ao mercado e “faz esse mundo girar”. Mundo esse que nega ao indivíduo a posição de sujeito, transformando-o em sujeitado pela própria relaçãocapital, uma relação social mediada por objetos do trabalho. Esse mundo que também o nega caso ele não seja um indivíduo rentável, nega a ele aquilo que se diz ser seu por direito, “humano”. Nega e apaga a história da produção social "na luta pelas coisas brutas e materiais, sem as quais não existem as refinadas e espirituais" ${ }^{107}$.

Na guerra se explicita a falência de um dos pontos do programa do Iluminismo e seus esclarecimentos: o de imposição da igualdade pela forma jurídica, uma racionalidade de equiparação feita através do tempo de trabalho abstrato efetivado no momento da troca de mercadorias qualitativamente distintas. O discurso do esclarecimento em defesa da razão é o mesmo que vê a tecnologia como possibilidade de superação dos problemas sociais, mas que ao mesmo tempo, contraditoriamente, oculta a melhoria tecnológica enquanto fruto da concorrência entre capitais, garantindo poderes de dominação à técnica ou a quem a porta, uma dominação que se apresenta neutra e sem sujeitos implicados em um fenômeno social totalitário, de massas, e que dispensa a reflexão crítica. O apelo tão comum que solicita “um uso humano da técnica” representa a inversão social que é abstração real, pois reitera a dominação das coisas sobre os homens sem perceber que o faz. Por isso, é necessária a crítica à "história das técnicas”, a esse historicismo sem determinação ou rupturas que ignora as mediações sociais e que preenche o "vazio" da linearidade do tempo com “mudanças tecnológicas”. Para Herbert Marcuse, “o poder tecnológico tende à concentração do poder econômico ${ }^{108}$ ".

O fascismo evoca o medo no plano individual e social como estratégia de estabelecer e fortalecer vínculos na delimitação de quem é in de quem é out frente a momentos de crise econômica. O pertencimento aparece como elemento chave no processo de construção identitária fascista que pode recorrer a mitos de fundação de determinado grupo. É o chamado “arcaísmo tecnificado” de Debord (1997) cuja finalidade é a proteção e manutenção dos meios de produção nas mãos dos portadores de tal identidade. Nesse sentido, dominar a técnica, escolher, manipular e reiterar certo discurso compõe o campo da racionalidade organizativa do fascismo que deve lidar com seu par dialético na irracionalidade das massas. O espontâneo e o organizado na sociedade de massas. Quais mecanismos transformam um indivíduo identificado com as massas? Esses 
mecanismos são, até que ponto, racionalmente escolhidos pelo indivíduo que personifica a liderança?

Como demonstra Crochík ao falar do ensaio de Adorno sobre a propaganda fascista ${ }^{109}$, embora a psicanálise freudiana seja falha no que diz respeito à análise das "condições históricas objetivas”, ela “fornece um quadro teórico importante para entender os dispositivos psicológicos do fascismo ${ }^{110 ”}$. Adorno aponta caminhos para essas questões ao afirmar que a propaganda fascista “toma os homens como eles são - os verdadeiros filhos da cultura de massa estandardizada atual, amplamente despojados de autonomia e espontaneidade” e diz ainda que esse tipo de propaganda “tem apenas de reproduzir a mentalidade existente para seus próprios propósitos ${ }^{111 ” . ~ A ~ r e p e t i c ̧ a ̃ o ~}$ compulsiva de um conteúdo pouco político, mas ao mesmo tempo de exaltação patriota faz parte das técnicas de manipulação do inconsciente das massas, segundo Adorno. A sociedade do fascismo, que utiliza-se de sua própria psicologia de massas para a dominação, se apóia na atomização do indivíduo que como parte de uma totalidade - a propaganda fascista sabe que seu monólogo deve absorver e tentar representar a totalidade dos momentos sociais e substitui seu narcisismo individual que se relaciona com a xenofobia pela imagem construída do líder que, como o indivíduo atomizado é um “(grande) homem comum”; uma "regressão artificial” na interpretação adorniana de Freud. Desta feita, segundo o autor frankfurtiano, o fascismo perpetua a dependência do indivíduo através da expropriação de seu inconsciente que passa ser socialmente controlado.

Spinelli faz uma análise interessante acerca das concepções racistas, do darwinismo social e do positivismo como legitimação científica do discurso de formação nacional da Turquia, seguindo os passos da criação dos Estados nacionais europeus. As declarações do ideólogo do Comitê União e Progresso, Dr. Nazim Shavid, carregam todo esse cientifismo racista. Em reunião secreta do Partido realizada em Constantinopla, formou-se um grupo de ideólogos e dirigentes ligados ao partido a fim designar uma comissão executora do programa de extermínio.

\footnotetext{
Os armênios são como praga gangrenosa, uma doença maligna que parece uma pústula por fora, mas que matará o paciente, se não for extirpada pelo bisturi de um cirurgião. Se vamos fazer algo semelhante ao massacre de Adana de 1909, o resultado nos causará mais mal do que bem. Se o purgante não é geral e final, prevalecerá o prejuízo. O elemento armênio deve ser extirpado da raiz. Não devemos deixar um único armênio vivo em nosso país. Devemos matar o nome armênio. Estamos em guerra: não poderíamos encontrar oportunidade melhor. Não haverá intervenção das grandes potências, e o clamor da imprensa não será ouvido. Desta vez, proponho a execução decisiva da operação de extermínio. Devemos eliminá-los de forma que nem um armênio fique vivo. Alguns de vocês perguntarão: “é necessário chegar a tais atrocidades?” Rogo-lhes, efendís, para não caírem em tanta ternura. Trata-se de uma doença maligna. Pensem na guerra. Com exceção aos turcos, todos os outros elementos devem ser exterminados, qualquer que seja sua crença ou religião. Esse país deve ser purificado de elementos estranhos, e os turcos devem realizar dito expurgo. (ACASP apud SPINELLI, 2011, p. 9)
}

109CROCHÍK, 2006, p. 159-163.

110Ibid., p. 7.

111ADORNO, 2006, p.186 
A autora ressalta que Shavid faz uso de termos científicos para explicitar a necessidade de extermínio. Pela lógica de Shavid, segundo a exposição de Spinelli, os armênios são tidos como doença que deve ser exterminada de maneira análoga a uma intervenção médica, criando uma “relação de dependência entre sintoma e cura”. A contextualização do cenário anterior à guerra de 1914 é tida como uma alteração do cenário geopolítico em que um império multiétnico que ligava Europa, África e Ásia, reduz seu território à porção asiática onde restava apenas a minoria armênia a ser exterminada na formação nacional de uma Turquia homogênea ${ }^{112}$. A invenção da Turquia homogênea havia de fazer o expurgo como dizia Dr. Shavid.

(...) o congresso do Ittihad, de 1910, em Salónica já o formulara ao falar numa "total otomanização de todos os indivíduos turcos, um nivelamento à medida turca dos Árabes, Curdos e Arménios. Para Talaat e os seus a igualdade teórica entre os povos do império prometida pela constituição não podia, de facto, inscrever-se na realidade senão depois de um processo de homogeinização forçada, uma turquificação efectiva (BRUNETEAU, 2008: 78).

O nacionalismo racista e genocida é formulado por Zyia Gökalp e, de acordo com Bruneteau, tem, de um lado, influência de Durkheim, de onde ele imagina uma sociedade política orgânica e integrada; do outro lado o sociólogo baseia um determinante populista e cultural a partir de Herder e Fichte (Bruneteau, 2008: 78). Com a perda dos territórios europeus, uma ideologia que tenta assegurar um império oriental muçulmano. Shavid e Gökalp, ideólogos de um pretenso estado turco homogêneo contém em suas formulações aquilo que Adorno aponta como "dispositivos prediletos dos agitadores fascistas (...) - consiste em comparar out-groups, todos estrangeiros, e particularmente os refugiados e judeus, com animais baixos ou daninhos” ${ }^{113}$. O historicista do progresso que preenche linearmente as "gêneses sociais" em um tempo vazio e homogêneo ${ }^{114}$ provavelmente entraria em desacordo, mas devemos estar atentos, ao olhar para o passado, às transformações mais imperceptíveis para além dos despojos atribuídos ao vencedor, na vitória dos dominadores $^{115}$.

112 “Os armênios são vistos como um perigo mortal, não é por aquilo que fazem ou não. A percepção do perigo é gerada pela alteração do contexto geopolítico que, desde Outubro de 1908, três meses depois da chegada dos jovensturcos no poder, vê a Turquia ir de uma derrota a outra. Essas são sucessivamente a independência da Bulgária, a constituição da Bósnia-Herzegovina em protectorado austríaco, a perda da Tripoliânia para os Italianos, e, na sequência da guerra perdida em 1912 perante a coligação dos Búlgaros, dos Sérvios e dos Gregos, a evicção da península balcânica. Em poucos anos, o império perdeu 424000 quilómetros quadrados e cinco milhões de habitantes tornando doravante uma entidade asiática. Mais ainda, estes acontecimentos haviam destruído o caráter multinacional e multicultural do império otomano, deixando os Arménios, em 1913, numa situação de derradeira grande minoria nãomuçulmana com caráter nacional” (BRUNETEAU, 2008: 77).

113 Adorno, 2006:182-3.

114 Cf. Tese 13 e 14 de Benjamin (1994), p. 229. O autor critica a noção de progresso como prática social-democrata, de um historicismo linear que reduz o caráter das particularidades e das condições materiais no desenrolar da história sobre uma sucessão no tempo e espaço abstrato, na lógica do tempo de trabalho abstrato (Marx), e homogeinizados pelo processo social de valorização do valor. A crítica de Benjamin ao historicismo de procedimento aditivo segue até o final do texto e desenvolve-se também com o termo “continuum da história”, a norma histórica do progresso.

115Cf. tese 4 de Benjamin, 1994: 223-4. 
A entrada na chamada Tríplice Aliança na guerra de 1914 se coloca aos olhos dos Jovens Turcos como momento oportuno para extermínio dos armênios. Estes eram representados como traidores da "fibra guerreira turca”, do Islã e entendidos enquanto possibilidade de perda de importantes territórios na Anatólia e no planalto armênio, fronteira leste do Império, como de fato ocorreu ao término da guerra, ainda que os armênios tenham sido exterminados muito além do que se configurou o território da Armênia.

Com quantos genocídios se faz um Estado homogêneo?

Como vimos, os Jovens Turcos perderam, nos primeiros anos de seu governo, mais territórios na fronteira oeste, os Bálcãs ${ }^{116}$, do que fez Abdul Hamid II em trinta anos ${ }^{117}$. Em 1914, a Porta entra em guerra contra o Império Russo, fronteiriço na região do Cáucaso, portanto, no assim chamado planalto armênio. O Império sofre uma serie de derrotas para o Exército russo nas suas campanhas do Cáucaso, como em Sarikamis ${ }^{118}$. A Primeira Guerra, do ponto de vista da formação dos Estados nacionais, foi um momento de modernização agudo das relações sociais de produção na Europa, mas também nos Estados Unidos da América. Um período de disputa e transição das hegemonias do mercado mundial, em que a gestão territorial pela forma do nacionalismo territorial e seu "protótipo democrático" (Kurz, 1999) se impôs e fez cair vastos territórios da decadente Sublime Porta.

A “mobilização geral” (Gaudemar, 1981), certo modelo de mobilidade perfeita da força de trabalho encontra suas experiências inaugurais na guerra de 1914, nem que para isso a mobilização seja fundada na expropriação e massacre; mas ao final da Grande Guerra é que o campo histórico do “totalitarismo econômico" (Kurz, 1999) está devidamente fundado no “mercado total”, seja ele liberal, misto, ou aparentemente apenas político-estatal.

Estudar guerra, matéria tensa nos coloca frente ao horror da destruição em escalas gigantescas. Não sem motivo Walter Benjamin em “Teorias do fascismo alemão” e também Marcuse em “Algumas implicações sociais da tecnologia moderna” tematizam a técnica ${ }^{119}$ e a

116“Em outubro de 1908, a Bulgária proclama sua independência. Ao mesmo tempo, Creta volta a pertencer à Grécia e a Áustria conquista as minorias cristãs adquiridas pelos militares designados a lutar nas fronteiras contra os separatistas dos Bálcãs são um dos principais motivos que farão o Ittihad a adotar, posteriormente, medidas drásticas contra a população armênia. Esse ódio é compartilhado por milhares de turcos que se vêem obrigados a deixar suas casas na região balcânica, em 1912, após a derrota otomana na região, e migrar para a Anatólia - região tradicionalmente habitada por armênios.(SUMMA, 2007: 19).

117 Talaat, o Ministro do Interior do Partido Ittihad, inverte a proporção da violência não por acaso: "Em três meses eu realizei o que o Sultão Hamid não conseguira em 30 anos” (KEMIRIAN, 1998)

118 Almeida, 2012: 9.

119 Diria Brecht, pela boca da personagem Ziffel, um físico refugiado em Helsinque durante a Segunda Guerra, em "Conversa de refugiados": “Apenas agindo com rigor ilimitado é que darão conta do recado. Com rigor podem transformar um covarde num monstro. Em princípio, você pode bombardear e arrasar a maior cidade do mundo empregando apenas funcionários subalternos, que tremem de medo quando se dirigem ao chefe da subseção. Trata-se de 
tecnologia para a guerra na subjetivação dos sujeitados dessas milhares de guerras formando uma imensa coleção de traumas. O choque da experiência ao não conseguir lidar com a memória e o silêncio na narrativa são temas caros a Benjamin em suas considerações sobre a obra de Nicolai Leskov, autor que se afasta de nós à medida em que sabe narrar experiências cotidianas com a exigida “distância” e “ângulo de observação”. Em tempos que a experiência está em baixa e deve desaparecer, pois “com a guerra mundial tornou-se manifesto um processo que continua até hoje. No final da guerra, observou-se que os combatentes voltavam mudos dos campos de batalha não mais ricos, e sim mais pobres em experiência comunicável”. A guerra de 1914, como Gaudemar escreveu, é uma guerra fundadora e para Benjamin o silêncio não era anormal, pois eram inéditas “as experiências mais radicalmente desmoralizadas que a experiência é a guerra de trincheiras, a experiência econômica pela inflação, a experiência do corpo pela guerra material e a experiência ética pelos governantes"; essa guerra funda o processo de extinção da "experiência que passa de pessoa é a fonte a que recorrem todos os narradores” (Benjamin, 1994:198). A narrativa de Leskov encanta Benjamin porque “ela não está interessada em transmitir o "puro-em-si” da coisa narrada como uma informação ou relatório. Ela mergulha a coisa na vida do narrador para em seguida retirá-la dele” (idem: 205) e assim, a narrativa gera interpretações múltiplas, pois ela é não é autoexplicativa. Embora não consideremos nossos relatos como narrativa, acreditamos que a potência de expor tais relatos esteja na possibilidade de gerar interpretações múltiplas.

Contudo, a situação de guerra em toda sua negatividade e explicitação da barbárie em nome da reorganização dos capitais, territórios e populações (a cada dia cresce o número de não-rentáveis) exige do estudante da guerra a tarefa de aprofundar a crítica da dominação impessoal do capital, pois ao se debruçar sobre a guerra, desvela-se a impossível narração do extremo absurdo; a relação social capitalista de racionalização das forças destrutivas em conflitos incessantes. A guerra constante não é mais exceção, aqui estamos de acordo com Gaudemar (1981). A imposição da mobilização de todos na crise da sociedade do trabalho a se arrastar sobre bases ficcionais do capitalismo, sempre a jogar com a possibilidade de transformar dinheiro em mais dinheiro, mas esse jogo de bolhas financeiras e oásis da rentabilidade não se faz sem violência extra-econômica.

Parece ser a guerra que, na autonomização dos soldados consumidores de outras mercadorias fez o dinheiro sair da margem das relações pessoais para destruir fortalezas e barreiras e aos poucos tomar o globo em nome do seu movimento de valorização do valor, a mesma guerra fundadora é hoje guerra destruidora na crise da acumulação da sociedade cadavérica do trabalho. A cada novo deserto de rentabilidade, mais acumulação de barbárie.

problemas técnicos. (Brecht, 2017 [1961]: 127)”. 


\subsection{1) Gyumri, três momentos}

Gyumri, 11 de agosto de 2016

Aqui a Armênia pra inglês ver acaba, aquela imagem dos cartões postais e o cenário ocidental da capital dão lugar a uma síntese do colapso: muitas fábricas fechadas há décadas, vestígios do terremoto e uma lgbtfobia atroz. Hoje, quando estava indo conhecer o American Corner, um local público com diversas atividades em parceria com o BirthRight, um homem velho me deu um leve soco no braço. Ele estava com uma cara de fechada e fez o que fez, segundo minha parceira de voluntariado, a armêno-russa Laura, por causa do meu brinco na orelha esquerda. Como quem diz: “aqui não, não me venha com essas viadagens”. Laura, nascida em Gyumri em 1995 e com uma peculiar história de imigração familiar, vive hoje em Frankfurt a estudar TI na universidade e contou-me que por essas bandas há uma "piada” mais ou menos assim... certo dia chega o filho do típico patriarca armênio em casa com um brinco na orelha. O pai de imediato o interroga dizendo: “das duas uma, ou você é maricas ou pirata. Vou olhar na janela do seu quarto para ver se há um barco parado logo ali, caso contrário...”.

Logicamente que há muito mais do que isso, mas, o conservadorismo dos cidadãos da segunda maior cidade da Armênia já me foi alertado algumas vezes. Felizmente, desde o dia 09, em Yerevan, quando recebemos as primeiras orientações do programa de voluntários, fiz amizade com Laura que é quase local, embora tenha permanecido pouco tempo aqui, pois sua família logo moveu-se para Rússia atrás de trabalho; atualmente vive na Alemanha. Tem sido uma ótima conversa, disposta a ajudar a quebrar as barreiras línguistas, além de saber muito sobre a história local. 


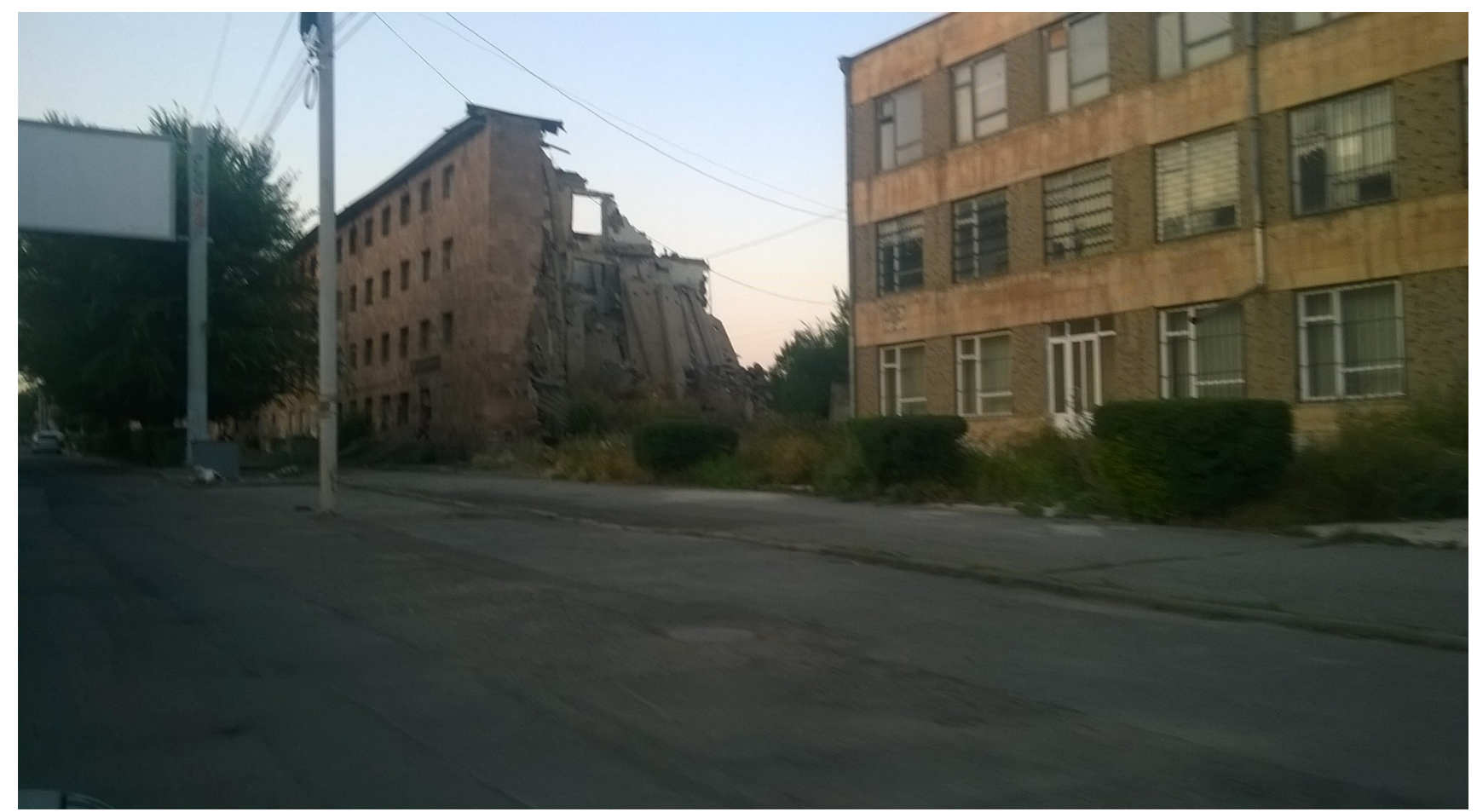

Foto 18 - Em Gyumri a primeira coisa que impressionou foi o prédio quase caído desde 1988 onde seguem vivendo várias pessoas.

Estou hospedado no apartamento de Lilia Podosyan e de suas filhas Anahit, Evelina Grigoryan, além do irmão que trabalha durante a semana em Yerevan, Vardan. A mãe não fala inglês e por isso o tempo todo dependo da mediação de suas filhas que, por sinal, falam inglês muito bem e isso porque de uns tempos para cá é necessário proficiência em angleren para ingressar nas universidades armênias. O apartamento está situado do distrito de Ani ou distrito 58, que foi construído após o terremoto pela simbólica combinação entre a gestão de reabertura de Gorbachev e a Cruz Vermelha Americana; no distrito também há prédios que contaram com a colaboração da Ucrânia e Bielorrússia. São vários conjuntos de prédios em um bairro todo planificado, com horta comunitária, quadras e arruamentos com pedras, mas nem sempre com asfalto. Apenas 15 minutos de ônibus do centro da cidade. Há muito o que investigar nesse mês que passarei por aqui, mas em apenas dois dias muita informação já apareceu. A base militar russa e seu respectivo bairro russo, as reformas há anos esperadas que foram aceleradas para a visita do Papa Francisco em junho deste ano, as viúvas que vestem apenas roupas pretas, a doação de Charles Aznavour para a reconstrução pós-terremoto que foi desviada não se sabe para quais bolsos e a forte imigração masculina para os dirty jobs na Rússia desde o colapso soviético, que tornou a cidade machista num lugar onde as mulheres são maioria, mas que até pouco tempo atrás não iam sozinhas aos cafés do centro. Evitemos pré-julgamentos e evitemos ainda mais relativismos culturais pós-modernos, mas há um clima tenso de violência no ar... 
Gyumri, 21 de agosto de 2016

Quem trabalha é quem tem razão

Ciro Monteiro

Dez dias depois e já acostumado com o horário local, com os colegas do programa de voluntariado, as coordenadoras, depois da primeira semana real de trabalho e das primeiras aulas de armênio, começo a captar algumas palavras soltas nas conversas alheias. Para uma voluntária egípcia que vive no Canadá, capaz de compreender cinco idiomas, e com quem tive uma rápida conversa em inglês e espanhol, o armênio e o árabe são as línguas mais difíceis. Nada animador. Yes sirum em sovorel lezuner (eu gosto de aprender línguas), mas nesse caso não tem sido nada fácil, pois o vocabulário, a pronuncia e os sons não batem em nada com o português.

Nas atividades laborais a coisa anda um pouco devagar, sempre necessitando de minha fiel tradutora, Valya, uma moça de 21 anos que me acompanha nas aulas de geografia no Endanik Center, uma entidade vinculada ao governo federal que oferece diversas atividades extracurriculares para o público infanto-juventil: xadrez, tear, línguas, oficinas de rádio e elétrica, etc. Essas aulas acontecem nas terças-feiras e quintas-feiras (yerekshabti e hingshabti, respectivamente) e atualmente estou lecionando temas relativos ao campo brasileiro para meninas de onze a treze anos. Nas segundas (yerkushabti) gasto meu tempo na preparação e na exposição de temas da assim chamada cultura brasileira, mas tenho que atender a demanda do público de um centro empresarialtecnológico e o resultado até aqui passa muito por um interesse estereotipado sobre música, comidas típicas, etc. Na sexta-feira (urbat) acontece o chamado serviço comunitário, em que os voluntários trabalham juntos e no momento estamos confeccionando um mural que imita um desenho de tapete armênio a partir de tampinhas de garrafas de vidro. Um encontro mais interessante tem ocorrido às quartas (chorekshabti) quando exibo filmes com temáticas políticas sobre a América Latina no American Corner, uma instiuição estadunidense que tem sede em algumas cidades armênias e visa promover a cultura estadunidense nestes rincões do Cáucaso. O primeiro documentário exibido foi “Notícias de uma guerra particular”, de Kátia Lund e João Moreira Salles, que trata da questão do tráfico de drogas no Rio de Janeiro, em especial no Morro de Santa Marta, o mesmo morro do filme de Eduardo Coutinho, com a diferença que este foi rodado dez anos antes, no ano de 1987. A sessão gerou um debate em que os mais jovenzinhos ficaram calados e a conversa desenrolou mais com um homem e um rapaz de 19 anos. Todos os três com dificuldade com o inglês, estou incluso nessa é claro, mas com vontade de trocar alguma ideia. Tentei, entre muitos comentários sobre o filme, fazer paralelos com a situação de Artsakh e fazê-los 
falaram algo sobre esse conflito; o homem mais velho disse que com mais tempo podemos conversar sobre. Um ponto interessante foi o momento em que eles afirmaram que estamos em uma guerra generalizada, no mundo todo. Saindo da esquina estadunidense, fui conversando com o rapaz que está para prestar seus dois anos obrigatórios e quer ficar na fronteira com o enclave azeri de Nakhchivan. Ele dizia que todo aquele território é armênio, bem como partes da Turquia e que existem muitas provas, como as khach kars (pedras cruz, símbolo do cristianismo armênio; para a língua portuguesa o som correspondente aproximadamente seria “ratch cars”).

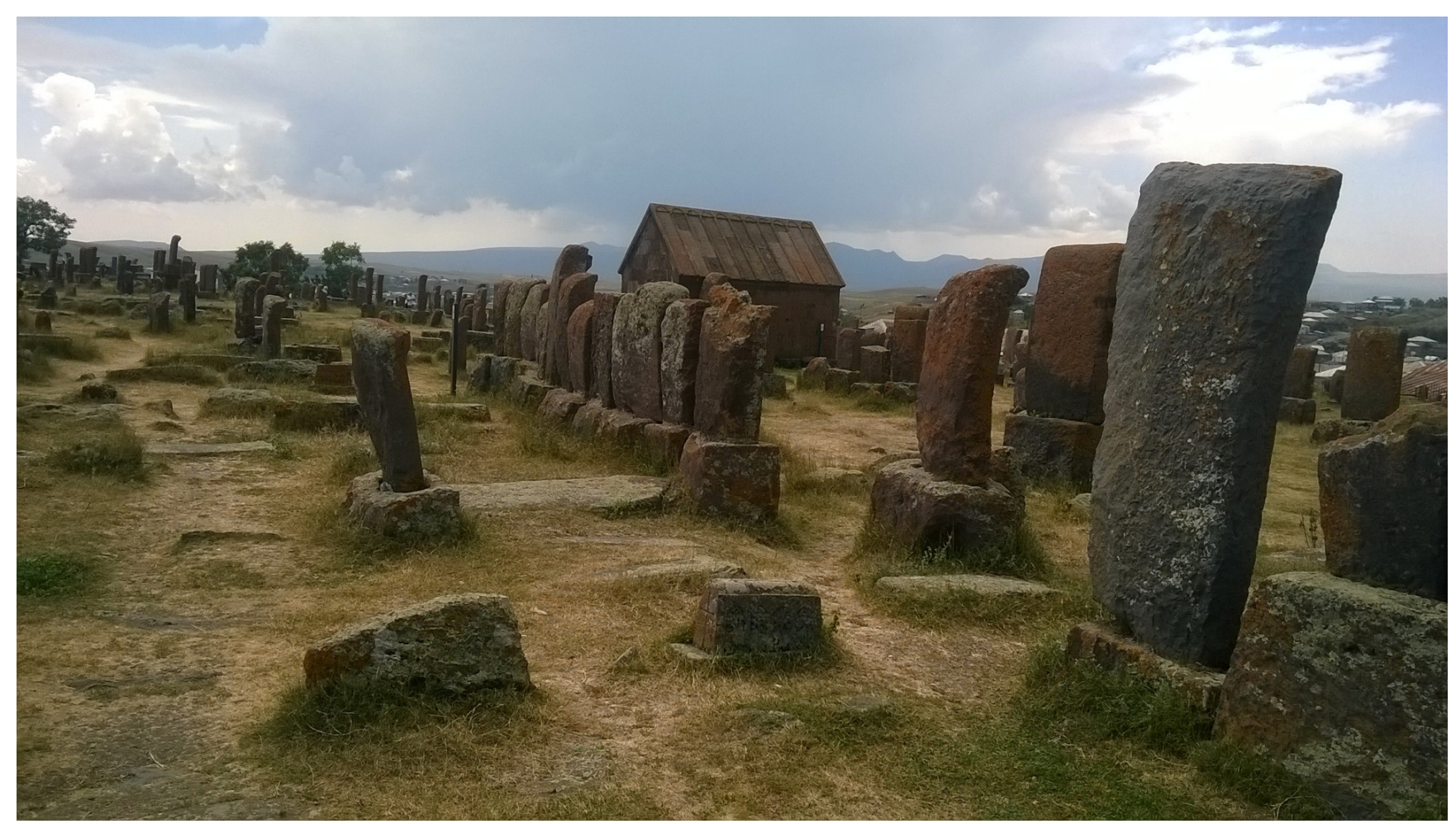

Foto 19 - Cemitério Norat, proximidades do Lago Sevan, algumas das khach kars lapidadas datam do século V d.C. Artur A. C. Camarero em 20/08/2016.

Otra vez más tive que bolar uma conversa tática para lidar com o patriotismo exacerbado, coisa que voltou a acontecer muitas vezes nos dias que sucederam a essa quarta-feira, mas as táticas nem sempre foram as mesmas. Isso tem sido, no mínimo, um grande exercício para meu inglês, mas mais do que isso, um confronto ideológico anti-nacionalista. Houve quem se indignasse com o fato de que uns tempos pra cá os azeris reivindicam para si a origem da flauta Duduk e o instrumento percussivo D’hol. O perigo do mal entendimento é constante, uma vez que a língua inglesa não me é tão confortável e o assunto tampouco. Dentre as tentativas de comunicação, proferi, no improviso, algumas vezes que "the nationalism is the step before the fascism" e surtiu algum efeito, pareceu que os interlocutores ficaram com uma pulga atrás da orelha. Guerra, (in)tolerância, cultura e religião eram palavras que soavam mais abstratas em São Paulo do que aqui. 
Hoje foi um dia agitado, que começou depois da madrugada papeando via Skype com gente querida no Brasil, seguido de serviço comunitário ao longo do dia e uma divertida aula de $D^{\prime} h o l$ no final da tarde. Antes de retornar à casa onde estou hospedado fui encontrar com algumas voluntárias e Razmig para nos despedirmos da canadense Tamar. Estávamos sentados num bar na avenida principal, Paruyr Sevak, do distrito de Ani. Nossa mesa estava composta por seis mulheres mais dois homens e na mesa ao nosso lado estavam alguns rapazes no visual "playboy armênio". Lá pelas tantas, as moças mais fluentes na língua perceberam que elas eram o alvo da playbozada do Toyota SUV, não paravam de encarar "as gringas gatas”, fazendo contas acerca da proporção macho-fêmea entre as mesas. O clima era horrível e, ao mesmo tempo, ridículo, tamanha a infantilidade dos rapazes. Algumas das garotas foram para casa antes, bem como o outro homem da nossa mesa. A essa altura, já visualizava que minha presença tinha algo a ver com a "segurança” das três jovens mulheres restantes, outra vez constrangidas pela situação ridícula. Mas esse era apenas o começo.

Os machistinhas saíram antes de nós quatro, mas montaram no carrão, meteram um pop daqueles péssimos no talo e ficaram as encarando, eu era só um detalhe para eles. Andamos em direção à praça da Igreja e os jovens iam e voltavam na avenida, fazendo conversões de $180^{\circ}$ para se reaproximar e encarar, rir e ameaçar. Quando chegamos na praça, eles imediatamente estacionaram o carrão. Tamar, que mora noutra direção, “se beneficiou” do fato de não representar o padrão de beleza que os “caçadores” perseguiam, e, literalmente perseguiram. Misoginia e machismo andando lado a lado, simultaneamente e, neste caso, eram partes da mesma coisa. Saímos andando em direção aos apartamentos onde as duas últimas “presas” estão hospedadas. Ali não sabia muito qual papel representar, mas sentia que minha presença de alguma maneira os distanciava. Conseguimos tirar uns metros de distância e logo que viramos à direita, saindo do campo de visão dos “caçadores” sugeri a elas, para que eles não descobrissem onde estão hospedadas, que corressem e elas o fizeram. O ridículo nos atingia mais uma vez, mas agora com ares de perigo. Felizmente hoje foi "dia da caça” e os caçadores sequer visualizaram a moita por onde “as presas” escaparam. Logo de cara, na primeira rua que virei em direção à casa onde estou hospedado, trombei com quatro dos caçadores que, com sorrisos de canto de boca, me perguntaram coisas em armênio, dei de ombros e segui andando. Ignorar a língua dessa vez ajudou. 


\subsection{2) Tripla Entrevista: anos escuros e frios}

Yerevan, 20 de outubro

Pensei em filmar entrevistas com Michael Baghasaryan (21/03/1982), Anna Hovhannisyan (11/01/1985) e Naira Melkhonyan (04/03/1961), meus colegas de quinto andar da Biblioteca Nacional da Armênia em Yerevan. Um esforço nada fácil, dado que além da situação constrangedora que uma câmera representa, a entrevista dependia de constantes traduções do armênio para o inglês feitas por Michael nos diálogos com Naira. A ideia era que os três abordassem a experiência da Armênia soviética e as diferenças pós-colapso, se foi possível perceber que a U.S. ia ruir ao longo dos anos 1980, se eles preferem hoje ou antes e o que mais que a conversa fosse trazendo.

Primeiro Anna não se sentiu à vontade de ser filmada, Michael que havia aceitado recuou no último momento. Até aí tudo normal, compreensível inclusive. Difícil não ser invasivo hora dessas. Depois veio a ideia de fazer uma entrevista coletiva, com isso quero dizer, entrevistar as três pessoas ao mesmo tempo. Aceitei tudo porque já percebia o desconforto que a situação estava causando e, ademais, situações inesperadas tendem a trazer resultados também inesperados. Por fim, já sentados à mesa com o pequeno e fantasmagórico capturador de vozes diante de nós, os possíveis entrevistados declinaram e sugeriram que fizéssemos na próxima segunda-feira (yerkushabti), 24 de outubro para que tivessem mais tempo para se preparar. Na espera, sigo aceitando.

Yerevan, 24 de outubro

Por conta da dificuldade de tradução do armênio para o inglês feita por Michael e desta língua para o português aqui escrito, a entrevista foi um tanto truncada, mas trouxe lembranças interessantes sobre o colapso da Armênia soviética e outros temas. Transcritos aqui os trechos mais pertinentes.

Naira: Nascida em Yerevan, sua avó do lado materno veio da cidade Van, atual território turco. Sua avó do lado materno veio de Bayazit ${ }^{120}$ (hoje Dogubeyazit, munícipio turco na fronteira com a Armênia). No passaporte de sua mãe está escrito Turquia 1915, muito interessante para a família que não sabia sobre isso. Eles não sabiam nada e foi a avó que os contou que a família foi 
transportada para Echimiadzin. A avó perdeu seus pais e todos os parentes. Crianças pequenas cresceram sem seus pais dentro dos orfanatos.

Artur: Diferenças entre o auge soviético, o colapso e a década de 1990.

Naira: Havia coisas boas em ambos períodos. No período soviético havia boas coisas socialmente, como por exemplo, não era um problema encontrar um bom trabalho e depois do colapso da União Soviética, muitas portas foram abertas e as pessoas se tornaram mais livres. A vida se tronou melhor em muitos outros aspectos, por exemplo, liberdade e relações com outros países e na União Soviética nós éramos limitados ao intercâmbio. As pessoas não eram autorizadas para ir ao exterior.

Artur: Gostaria de saber mais sobre o momento do colapso e se ela percebeu na época que o colapso ia acontecer?

[Michael sugere que ele e Anna contem sobre suas lembranças de infância e o colapso soviético].

Anna: Suas lembranças são de depois do colapso da União Soviética, pois ela era pequena naquela época. Lembranças do começo dos anos 1990. Nos chamamos de “anos escuros e frios" aquele período em que não havia eletricidade, nós não tínhamos gás e não havia nada para aquecer as casas. Acendiam velas.

Naira: Começou a melhorar no ano de 1995, passamos a ter luz elétrica e nós sobrevivemos a esses anos terríveis.

Michael: Talvez eu possa dizer algumas coisas sobre esses anos de minha infância nos últimos anos da União Soviética, o colapso e depois. Como aconteceu com Anna, não consigo lembrar exatamente do período até o colapso. Eu também era uma criança e posso lembrar da situação política no país, não havia produtos nas lojas e mercados. Era difícil encontrar até o básico, produtos a exemplo de pão que nos davam por meio de cupons e era limitado. A cada pessoa tais e tais quantidades de pão, nem um pouco a mais. Assim foram esses anos terríveis. Eu me lembro das Paradas de Gala desse período que ocorriam antes do colapso da U.R.S.S. Nós éramos crianças e nossos pais nos levavam às Paradas onde havia muitos balões e coisas assim no período soviético. Essas são minhas lembranças daquele tempo e me lembro, depois do colapso, posso dizer alguma coisa. Eu era uma criança e não entendi, era o ano de 1992, que não havia mais U.R.S.S. e me lembro que minha irmã mais velha me disse isso que a U.R.S.S. não existia mais. Não entendi e não me interessei muito porque como criança pensava se a Armênia se tornaria independente e se tornaria como um país europeu, como a América. Um país desenvolvido como eles e nós não entendemos que aquele era apenas o começo de um tempo difícil e de um difícil caminho. Depois disso vieram os anos difíceis de escuridão sem eletricidade, como te disse. Eu me lembro mais daquele período depois do colapso porque eu já era mais crescido. Anos escuros, como 
costumamos chamá-los e ainda agora chamamos, as crianças armênias relembram daquele tempo como “anos escuros e frios” (Tsurt Mut'yev ts'urt tariner). Os primeiros anos dos 1990, de 1992 a 1995.

Artur: Você se lembra quais eram as estratégias para aquecer a casa, para ter luz?

Michael: Para ter luz, como te disse, nós tínhamos as velas. Para aquecer as casas usávamos o fogão e queimávamos madeira lá, trabalhávamos com madeira. Isso era muito desconfortável, você entende. Havia muita fumaça e todas as paredes das casas ficavam com marcas da fumaça do fogão. Depois disso, a vida passou a ter mais brilho, literalmente.

Artur: Você quer falar mais sobre a história de seus parentes refugiados? Do período depois da Primeira Guerra...

Michael: Eu posso dizer que muitos armênios, muitos conhecidos, pessoas que conhecemos, naquele tempo fugiram do país, não sei é certo dizer. Saíram do país para os EUA e outros países para viver uma vida mais confortável que aquele período duro. Muitas pessoas chegaram, eles chegaram para sua terra nativa, terra natal (homeland).

Artur: Sobre seus parentes, você tem memória das histórias deles? De qual cidade eles fugiram, qual caminho fizeram para chegar na Armênia?

Michael: A maior parte dos refugiados, penso que fugiram para Los Angeles - EUA, França talvez sim. A maior parte para os EUA, até onde eu sei, naqueles anos o governo dos EUA estava deixando pessoas chegarem, não de todos os países...

Eu nasci em Yerevan, meus país também. Nasci e creci em Yerevan, vivi minha vida aqui, estudei e trabalho aqui.

Artur: Seus avós maternos e paternos vieram de regiões diferentes?

Michael: Meus parentes do lado materno vieram de Tigranakert, Armênia do oeste.

Artur: Hoje em dia Nagorno-Karabakh?

Michael: Não, não. Tigranakert é da Armênia do oeste, não Stepanakert.

Artur: Mas Tigranakert está dentro de Nagorno-Karabakh, sim? O forte...

Michael: O forte pode ser, mas há uma cidade que agora é parte da Turquia [que era denominada]

Tigranakert $^{121}$. Daquela parte, quero dizer.

121 Há mais de uma cidade com esse nome, que significa feita por Tigran, em algumas localidades entre Turquia e Armênia. Provavelmente a cidade a que se refere o entrevistado esteja localizada na atual cidade turca de Silvan a leste de Diyarbakir. 


\subsection{3) Yerevan, 02 de novembro - empreendedorismo social, o capitalismo de bom coração}

Essas são anotações sobre o havak (encontro) oferecido pelo BirthRight Armenia sobre empreendedorismo social na Armênia apresentado por Artak Melkonyan. Tentaremos usar as ladainhas que foram expostas nesse havak para pensar a situação do colapso e pós-colapso soviético no próximo item.

Uma a cada quatro start-up's da Europa são orientadas ao “empreendedorismo social”. Baseado na apologia da divisão social do trabalho para o conforto e a riqueza. Puro Adam Smith. Benefício próprio e mão invisível.

A citação que dava sustentação a tudo isso vinha da “teoria dos sentimentos morais” de Adam Smith, texto publicado em 1759, para explicar a natureza humana e suas propensões egoístas.

Companias Sustentáveis, Lógica de controle, proteção de IP, maximizar lucros.

Interesse próprio

Maximização dos lucros

Empresa firme/sólida

Capturar valor
Interesse no outro

X Maximização dos impactos

Solução sustentável

Criar valor

(Mudança positivamente sistêmica no

Ecossistema, Código aberto e compartilhado)

Business + caridade $=$ empreendedorismo social

Como não separar, como juntar altruísmo com lucros?

Atingir problemas sociais negligenciados desafiando o conhecimento tradicional através de modelos de negócios inovadores que empoderem o povo para entregar soluções sustentáveis atingindo múltiplo impacto na vida das pessoas.

"Solução social” / "Inovações sociais”

Problema: minas (bomba)

Resultado: campos minados (remover \$1.000, produzir \$ 3) 
Solução: treinar mulheres para “desminar” Karabakh. Inserção econômica dessas mulheres, fato comemorado pelo palestrantes mesmo com o explosivo perigo do ofício, mas com a ressalva de que os ratos “desminadores” na Tanzânia são uma opção mais fácil, rápida e barata (faltou dizer mais descartável).

Outros exemplos: sal colorido, colher comestível, pague quanto quiser, “Cola life”, Odon device bomba para partos em sacola plástica.

O intuito é colocar as chamadas o "business social e a responsabilidade" dentro das grandes firmas Política pública deve estimular o ecossistema (aqui a mão invisível pede uma ajudinha constante ao Estado).

Mais eficiência com a dupla/tripla linha de reportes sobre problemas técnicos dos procedimentos. Governo se torna um comprador dessas empresas (a mão invisível agora é a mão que garante que o dinheiro chegue a esses “negócios sociais”)

O foco dos esforços da diáspora é a filantropia; (outra vez más armenidade aparece como clube internacional de crédito). Esforços da diáspora “implementaram com êxito projetos de empreendimentos sociais sustentáveis de vários milhões”.

60\% das receitas do país vem de fora da Armênia. Diaspora AID, Ong's internacionais. Atualmente estão expandindo as start-up's junto com a emergência de ações relacionadas à ecossistemas de incubadoras e aceleradores.

O pulo do sapo: Armênia tão atrasada na concorrência pode ver o que deu errado no caso de outros países para pular etapas (Leapfrogging - conceito de Schumpeter)

Finanças, Logística de escritório que para o expositor pulam etapas do atraso: máquinas de voice mail, phone books, máquinas de pintura eletrônica, impressoras 3D.

Professões: milkman, ice man, lift operator. (a mesma crença velha de que serviços e trabalho improdutivo podem além de ocupar as mentes vazias, gerar valor).

Contraditóriamente de um lado, diminuição de postos de trabalho com o pulo do sapo (leapfrogging) e a pulverização do microempreendedorismo que, ao falhar, se deprime na subjetividade falida de quem não realizou o que deveria, a ilusão do sujeito e o problema de ser sujeitado. 


\subsection{4) Da modernização retardatária ao pulo do sapo}

A esperança da “inclusão social” pelo trabalho, essa lenda rarefeita que se arrasta desde a terceira revolução industrial, renova ilusórias esperanças ao sujeitado sujeito em conceitos cadavéricos da sociedade produtora de mercadorias tais quais o nacionalismo, o racismo, a fé no pleno emprego e um ethos do trabalho da economia de guerra retardatária do socialismo que "tinha que ser mais absolutista que o absolutismo e ter uma economia de guerra mais acentuada que na própria situação de guerra” (Kurz, 1992:62). A manutenção da guerra pós-colapso da póscatastrófica região de Nagorno-Karabakh - hoje território de Artsakh com apoio militar armênio, a língua na rua e os drams (moeda armênia) na mediação social do dinheiro para uma pequena população que depois do conflito tornou-se "homogênea" - se alimenta e movimenta a indústria russa de armamentos.

Enquanto os direitos humanos clamam pelo valor ético-moral cristão da tolerância, o que se tolera realmente são os massacres das populações, em especial as populações não-rentáveis, “naturalmente” para e na reorganização de capitais nos desertos da rentabilidade que se tornaram miragens 25 anos pós-colapso soviético. A esperança na sociedade do trabalho em crise tem, por outro lado, tolerância indiferente à violência extra-econômica que recai sobre os não-rentáveis. Dá de ombros e diz:

- Não é comigo mesmo.

E sai como em um “pulo de sapo”, pois afinal, “bandido bom é bandido morto”.

$\mathrm{Na}$ sociedade acumuladora de barbárie, o espetáculo e seu monólogo laudatório da mercadoria ${ }^{122}$ dão voz à auto-promoção nas redes sociais, à imensa legião virtual de empresários da própria miséria, sua imagem e semelhança. Tal posição virtual do sujeito com suas "máscaras de caráter” caminha sobre a esteira em movimento da fé cega na sociedade do trabalho em crise como mera “questão de mérito” até o dia que a água bate na bunda... e aí, se não se incorporou, adaptou, flexibilizou ou morreu, o sujeito sujeitado carece de ter paciência para, quem sabe na próxima rodada de capital fictício, tentar se agarrar numa ponta de corda e sair, com créditos que aparentam méritos, do fundo do poço.

A modernização retardatária das regiões abarcadas pelo socialismo real apoiou-se na ideologia do trabalho à medida que

limitou-se a contrapor determinadas categorias reais burguesas a seu pólo complementar: o "trabalho" ao "capital", o elemento estatista ao monetarista do princípio concorrente. Mas essa ideologia tinha seu firme fundamento material nas próprias circunstancias, e também sua 122DEBORD, Guy. A sociedade do espetáculo. Trad. Estela dos Santos Abreu. Rio de Janeiro: Contraponto, 1997. 
imposição real em regiões relativamente pouco desenvolvidas da socialização mundial capitalista nascente não foi nenhum "erro", mas sim resultado dessas próprias circunstâncias (Kurz, 1992: 83).

O princípio da concorrência no seio da economia de comando stalinista teve que abolir a concorrência "por causa da concorrência” (idem) para que essas regiões internas à U.R.S.S. não fossem sugadas pela economias ocidentais de modo a reverter "internamente" as massas de maisvalia no sentido de uma acumulação interna voltada, forçadamente, às indústrias básicas e de infraestrutura. Até o momento em que essa fase representava um crescimento extensivo do sistema produtor de mercadorias soviético espalhou "uma espécie de euforia de desenvolvimento”. O Estado socialista, assim, tentou controlar princípios fetichistas da concorrência em sua realização da produção no mercado interno através do controle e planejamento burocrático, mas o mesmo estatismo que alavancou o mercado mundial destruído no pós-guerra mostrou-se insuficiente na corrida pela riqueza abstrata e a economia de guerra mostrou-se sua obsolescência e o planejamento da mais-valia se reverteu em estagnação e escassez de mercadorias. Essa gestão soviética deflagra que o caminho trilhado em sua modernização não era outra coisa que uma "missão civilizatória do capital, na máscara socialista da economia de guerra estatista” (ibidem: 84). Para Kurz, determinada “literatura edificante socialista” que andou junto com essa “acumulação primitiva recuperadora” se transformou em propaganda estatal, mas que tinha seu revés na "grande mentira na periferia ocidental da União Soviética”, onde a Armênia e outras ex-repúblicas soviéticas se encontram. “Ali a imposição de uma economia de guerra estatista jamais teve nenhuma justificativa histórica, nem sequer relativa, nas condições do desenvolvimento" (op.cit.:85). No entanto, pensando na particularidade do caso da Armênia que entre 1918 e 1920 formou sua primeira República territorialmente, vivendo durante esses anos com ataques dos turcos sob a batuta de Mustafá Kemal “Ataturk” e que se rendeu aos bolcheviques em dezembro de 1920 para ser incorporada - em conjunto com Geórgia e Azerbaijão - à Federação Repúblicas Soviéticas da Transcaucásia até $1936^{123}$, dali até o colapso cada uma destas repúblicas passou, individualmente, a figurar as Repúblicas Socialistas Soviéticas. A imposição de uma economia de guerra foi questão de sobrevivência em um momento saído da guerra de 1914, ou seja, a mobilização de todos no processo social fetichista de produção da riqueza nacional abstrata vem se manifestando nos últimos 100 anos como guerra, conflitos armados, massacres, economias estatistas baseadas em guerra e a guerra da concorrência nos mercados pacificados "sob a égide da Pax Americana” quando o auge fordista se libertou da economia de guerra e crise. O contexto da década de 1970 do capitalismo

123 Para aprofundar nesse assunto conferir o capítulo segundo da Dissertação de Mestrado de Loureiro, 2012. Em especial o item “A República de 1918” na página 71. Neste capítulo o autor comenta a criação de cada uma das instituições beneficentes, partidos políticos, Igreja e escolas em São Paulo, mas atento à sua correlação com Armênia e outros destinos assim da chamada "diáspora”. 
ocidental liderado pelos EUA no desenvolvimento das forças produtivas que açambarcou, just in time, a micro-eletrônica com as ciências e fez da intensificação da produção (mais-valia relativa) o novo recado da "coação muda" da concorrência e é nesse ponto que a economia de comando soviética, presa ao aumento da produtividade pela extensão da jornada (mais-valia absoluta), vai sofrer sua “petrificação”. E como “a vida castiga aquele que se atrasou” 124 não bastou a vontade dos sujeitos burocráticos a planejar demandas e encadeamento entre os setores da produção, falsos balancetes das empresas repassadas ao Estado ou propaganda moral ao trabalhador pela honra do trabalho improdutivo. A impessoalidade e a "coação muda” da concorrência ocidental deflagaram como o planejamento burocrático do socialismo real foi sendo ultrapassado na corrida mundial da produção de mercadorias. Se, de um lado, a incorporação dos micro-computadores abriu a rota de auto-destruição tendo como horizonte lógico-histórico a supressão do trabalho e a crítica queda tendencial das taxas de mais-valia e lucro no Ocidente; por outro lado, o estatismo da economia de guerra soviética ao conservar o dispêndio de trabalho perdeu o fôlego e "extingui-se, portanto, abaixo da sua 'massa crítica'”. A crise e o colapso do bloco soviético se desdobrou desse momento em que a economia desenvolveu-se em escala mundial, mobilizando a todos na busca cega atrás de seu quinhão da mais-valia global ${ }^{125}$.

A crise é expansão e a expansão gera crise? A Armênia de hoje, passados 25 anos do colapso, além de alimentar com seus imigrantes um mercado sazonal da Rússia, alimenta também o sonho do mercado de trabalho de seus jovens através da promessa representada na carreira de Tecnologia da Informação, a profissão que melhor expressa a contradição atual da sociedade do trabalho em crise: programar máquinas substituidoras de trabalho. Sob as ruínas deixadas pelo colapso há quem possa ver vantagens no atraso e não um “castigo” da vida que é o capital, uma vez que de trás se pode ver os atalhos e "saltar como um sapo" (leapfrogging) as “etapas desnecessárias ou não-sustentáveis ecologicamente” da modernização e assim alcançar a ponta da corrida da concorrência. Mas, “o exame isolado da crise final do socialismo” e a espera da salvação e retorno à rentabilidade e valorização do valor, a crença que um dia a corda apareça no fundo de algum poço “deixa de reconhecer a lógica do princípio da concorrência, a qual, como emancipação negativa, se descarregará em futuros surtos de crise da produção mundial de mercadorias” (Kurz, 1992: 90).

124 Frase de Mikhail Gorbachev que Kurz retoma ao final do capítulo "Concorrência e emancipação" no livro "O colapso da modernização".

125 Na casa onde fiquei hospedado em Gyumri recebemos a visita de Tatev e sua mãe Rasmik, com quem conversei mediado pela tradução de Evelina, a filha mais velha da família que me hospedou. A senhora estava interessada em saber sobre as semelhanças entre Brasil e Armênia, sobre o sistema educacional brasileiro, já que é professora e diretora de escolas na Armênia. Por outro lado, perguntei sobre o período soviético e, entre muitas opiniões, Razmik disse que naquele tempo era "melhor, todos viviam bem, sem diferença entre ricos e pobres. As pessoas trabalhavam em suas respectivas áreas, mas hoje um especialista vira lojista e agora tudo é pago". Sobre Stálin disse-me que "ele era esperto e muito rude”. Quando perguntei sobre o colapso da URSS veio a maior surpresa: sua tese de que Gorbachev tinha um acordo com os Estados Unidos para colapsar a URSS! No mínimo interessante... 
Numa grande percentagem, a economia actual corre em transacções no mercado financeiro e em cadeias transnacionais de criação de valor, isto é, de investimentos de racionalização, explorando a redução de custos. É justamente uma riqueza mercantil superficial que por maioria de razão exige aqui tal exploração exaustiva e que ocorram deslocalizações do investimento para outras partes do mundo condicionadas pela racionalização, nas quais depois é exercida uma exploração maciça da força de trabalho, sendo que no seu conjunto baixa a massa de valor e o trabalho abstracto na sua "substância material abstracta”(Scholz, 2016).

Ainda junto à Roswitha Scholz na trilha da crítica da acumulação primitiva infinita, as relações de exploração já constituídas mundialmente "são sobretudo mediadas pelo crédito e não em último lugar financiadas no contexto de um circuito de deficit”. Para que mais? 


\subsection{5) Yerevan, 25 de novembro}

Com quantos quilos de medo se faz uma tradição?

Tom Zé

Para Marina ${ }^{126}$

A um dia de partir rumo à Geórgia e outros destinos, a experiência armênia parece herik (suficiente em armênio). Foram quase quatro meses trabalhando, conversando, viajando e me ambientando nesse pequeno país tão orgulhoso de suas tradições e tão pouco crítico em relação aos processos violentos de invenção e aceitação de qualquer tradição. Nesses últimos dias a cegueira do nacionalismo apareceu algumas vezes, a mercadoria mais valiosa daqui é a tradição que vende e orienta discursos e representações intensamente. Tradição que (p)reserva posições e afazeres bem marcadas para os gêneros e suas personificações.

Junto a isso está atada a antinomia do direito patriarcal que, por exemplo, favorece assassinos e agressores, fazendo-os ter a guarda de seus filhos por meio de um resguardo judicial dado eles e dispensado às mães. Igual, cega ou cinicamente seguimos a fazer vistas grossas quanto a diferença de possibilidades de trabalho entre homens e mulheres. Logicamente não cabe a defesa fetichista da igualdade de gênero pautada na igualação como um todo e em especial das condições do trabalho abstrato. Historicamente essa igualação resultou em mais sobreposição de esferas dissociadas às mulheres em nome de maior "respeitabilidade" frente ao mercado de trabalho ao engatar mais ainda esferas dissociadas do processo de reprodução de quem trabalha e constitui família. A tal “questão da mulher” na Armênia engatinha, “mas tudo bem, sempre foi assim” e assim seguem as tradições do patriarcado armênio, que é parte de um todo. Hoje o país ocupa o segundo lugar no campeonato mundial de aborto seletivo, aqueles que acontecem porque prefere-se o varão a menina, atrás somente da China. A mulher armênia, bem como todas as mulheres que vivem sob o signo do patriarcado na modernidade, enfrenta todos os dias um mundo dominado pelo valor do homem. Apesar de serem quase metade da população da capital, apenas duas mulheres compõem o parlamento e nenhuma está a frente de prefeituras. Mais da metade das mulheres do

126 Marina Thaler Machado foi uma brava companheira de todas essas viagens, dos relatos platinos à Armênia e todas as andanças e caronas até Lisboa quando regressei ao Brasil para escrever. Ela ainda trabalhou como voluntária nas ONG's Woman Resourch Center e Woman Support Center em Yerevan entre setembro e novembro de 2016 e muito me informou sobre a "questão da mulher" especificamente armênia. Como a escrita imita a vida, a mulher informa o homem sobre a dissociação, recolando os termos do valor-dissociação. Ainda que a autoria fique em meu nome, muitas ideias e observações de Marina estão neste relato. 
país estão desempregadas e seus salários, em geral, correspondem a 64\% dos salários masculinos. As (des)afortunadas que encontram um lugar no mercado de trabalho ocupam em sua maioria lugares secundários (além de enfrentarem uma dupla socialização, e não “dupla jornada de trabalho" como usualmente as correntes feministas interpretam), ainda que o acesso ao ensino superior seja uma realidade na capital. O lugar relegado à mulher na sociedade armênia fica então evidente: no invólucro do lar, isso é, a casa e todo o conjunto de atribuições e 'virtudes' a ela relacionada ${ }^{127}$. Eis então que, em casa, confinadas à segurança familiar que só um verdadeiro lar patriarcal e heteronormativo pode prover, a mulher armênia se vê frente a frente com o seu maior temor: a violência doméstica acumpliciada pelo Estado. Por aqui, não há nenhuma lei que criminalize a violência contra a mulher, que distinga o feminicídio de um homicídio. Os números não são menos impressionantes: 59,6\% das mulheres relataram já terem sofrido violência doméstica ${ }^{128}$; em outra pesquisa, $9 \%$ responderam que já sofreram violência doméstica sob forma física, 25\% sofreram intimidações psicológicas, 61\% tiveram seus comportamentos controlados e 3,3\% sofreram violência sexual ${ }^{129}$. O código penal armênio classifica diversos crimes referentes à violência doméstica [art. 109/110] como “casos de acusação particular”, o que sustenta o fato de que a violência doméstica seja considerada um problema privado e familiar.

Em 2013, o governo armênio rejeitou um projeto de lei referente à violência doméstica coelaborado por cerca de 5 anos por ONGs e alguns representantes políticos. O projeto previa medidas de proteção civil, assistência para as vítimas e penalidades para os acusados. Entretanto, nos últimos anos o governo armênio, ansioso e aspirante por ser reconhecido e quem sabe introduzido à União Européia (e enfim ficar de uma vez por todas livre do gigantesco fantasma russo-soviético) cedeu a algumas pressões internacionais quando o assunto foi disparidade de gênero. Em 2004, anexou o artigo 22 ao código trabalhista enquadrando a violação da igualdade de direito entre homens e mulheres e/ou o assédio sexual entre funcionários, subordinados e beneficiários, como uma violência grave à disciplina do trabalho (afinal, o que importa mesmo é que todos sigam produzindo). Cinco anos mais tarde, em 2009, o governo assinou um plano de ação estratégica para o combate da violência de gênero, curiosamente contraditório, então, com o rejeitado projeto de lei elaborado em 2013. Pois bem, coube as mulheres mais uma vez se organizarem para serem ouvidas: emergindo das brechas do Estado (e recebendo esmolas do capital

127 Vale ressaltar os relatos de mulheres que foram hostilizadas por fumarem na rua, enquanto os homens mascam cigarros, bem como os "conselhos” que mulheres mais velhas dão às garotas estrangeiras que, superficialmente, já se livraram de algumas amarras machistas: 'volte para casa antes de 22:00 horas, a rua não é um bom lugar para mulheres depois dessa hora'. Em Gyumri, mais de uma garota nos disse que seus familiares não as deixam sair sem a companhia de algum homem, seja irmão, pai, tio ou namorado.

128 Dados da Proactive Action de 2011. Disponível em: http://www.stopvaw.org/armenia

129 Dados da United Nations Population Fund (UNPF) de 2010. 
estrangeiro), sete ONG's reunidas em uma grande coalizão (Coalision to stop violence against women) tomaram para si alguns dos deveres do Estado, como 'igualdade, solidariedade, justiça social; não discriminação, tolerância a todos os grupos da sociedade; propagação de direitos humanos e valores democráticos; formação e promoção da sociedade civil sem violência’. O que se enfrenta são casos sinistros dessa justiça que segue nos trilhos da antinomia do direito patriarcal ${ }^{130}$.

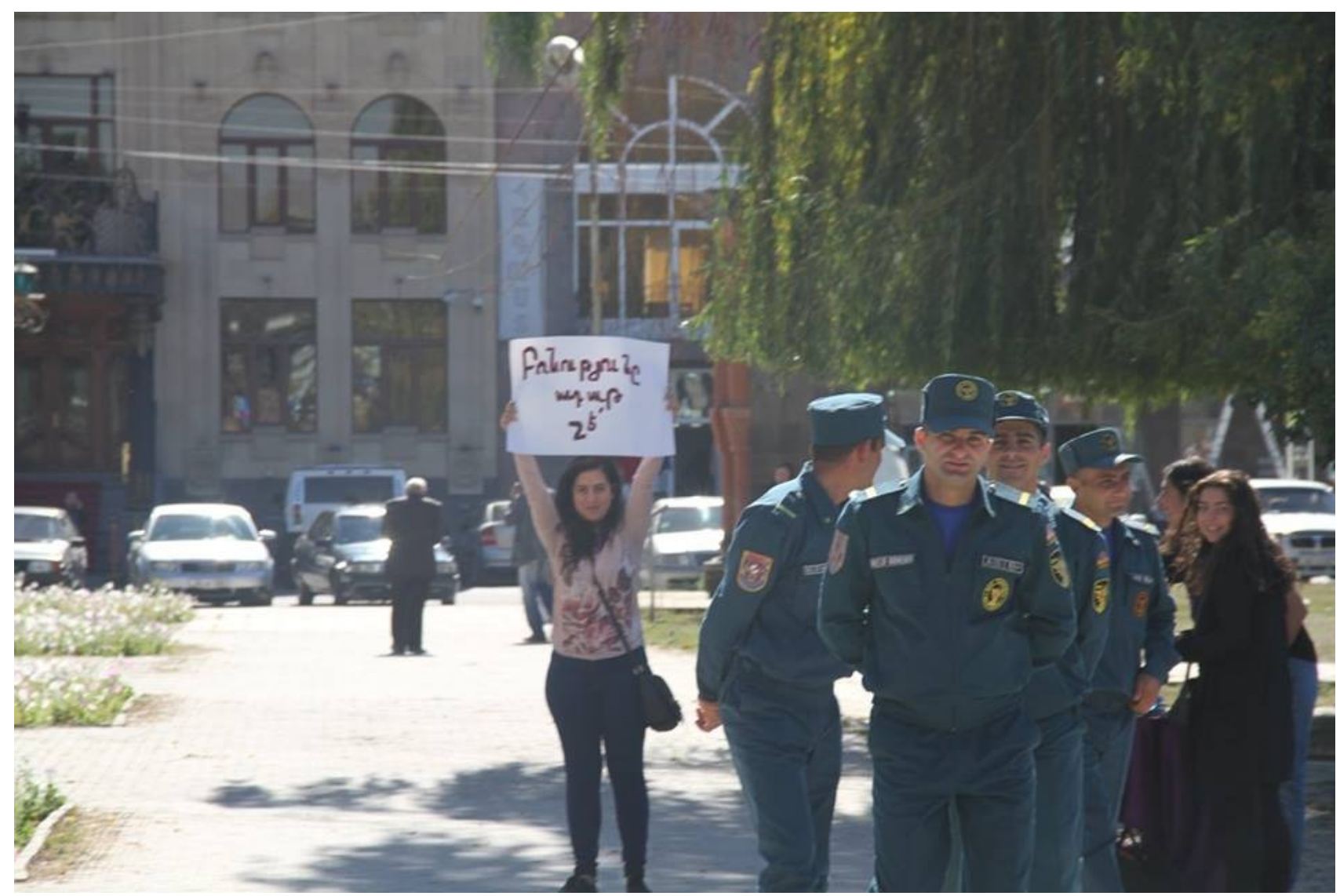

Foto 20 - Em Gyumri o cartaz segurado pela militante próxima aos policiais diz em armênio que "violência não é tradição”. Marina Thaler Machado em 09/10/2016.

Dispensada aqui qualquer apologia do Estado na sua forma de gestão de crise, em seus deveres e "nossos" direitos de sujeitos iludidos dentro de qualquer território de "riqueza nacional abstrata” (Kurz, 1992), assim como da posição de urubu do rentismo “social” exercida pelas ONG's. Cabe deixar evidente que o cerne do problema está na própria forma social capitalista através do Estado, sendo essa uma forma que privilegia e sustenta o valor do homem em detrimento do valor da mulher, uma forma do fetichismo moribundo que quer dar mais um contralance na busca da vitória pela pseudo acumulação, mas para que mais? Concretamente, o valor-dissociação 130 Há diversos casos em andamento, como o da guarda do bebê que segue com um pai que a machadas matou os sogros e golpeu sua mulher na cabeça, que felizmente já está recuperada e que luta para ter de volta a guarda de seu filho, no entanto, a decisão foi favorável ao pai que alegou estar em estado mental alterado ou coisa parecida. Peleja-se também em relação a um bebê sequestrado na maternidade que a mãe decidiu ter e era encomendado a outro casal que hoje tem a guarda da criança contra a vontade da mãe; por fim, dentre tantos relatos de minha companheira de trabalho de campo e tantas viagens de pesquisa, há o caso da trompa arrancada dentro do hospital para tráfego de órgãos. 
toma forma de antinomia do direito (Marx) que tende sempre ao homem e relega à mulher armênia o surrado e sem valor das atividades dissociadas da esfera pública que, ainda que na visão de algumas vertentes feministas devesse ter o seu valor equiparado ao trabalho abstrato, o que não acaba com a forma de dominação patriarcal no capitalismo.

A igualação da mulher ao homem na sociedade moderna, no que se refere aos aspectos relativos a oportunidades de trabalho, remuneração e direitos, pode sim trazer mudanças para a vida cotidiana dessa mulher, isto é, a mulher que alcançar a sua independência econômica no “totalitarismo econômico” (Kurz, 1999) e também alcançar outras (in)dependências reificadas a mais, como a simples possibilidade material de divorciar-se ou não. Assustador é ver que estamos ainda atrás do reformismo social-democrata do início do século XX. É inegável que, nesse aspecto, o alargamento dos direitos pela via do trabalho pode sim constituir uma das vias de "emancipação da mulher”, mas essa emancipação é volátil e mistificada. A incorporação das mulheres ao universo do trabalho abstrato - que em grande medida as correntes feministas contrapõem ao trabalho doméstico - não garante nenhuma mudança no seu estigma social, pelo contrário, parece reforçar ainda mais um estigma já antes difícil de ser carregado: mais do que boa esposa e boa mãe, agora ela também deve ser uma boa trabalhadora.

No pós-fordismo, com a revolução microelectrónica, dissolvem-se as instituições da família e do trabalho remunerado, na sequência dos processos da globalização, que eles próprios resultam do processo da dissociação-valor; as relações de género tradicionais desfazem-se sem que desapareçam as hierarquias de género. As relações entre os sexos no patriarcado capitalista asselvajam-se mesmo. O homem como ganha-pão da família e a mulher como dona de casa tornam-se obsoletos; as relações de género são agora aparentemente individualizadas, as mulheres são “duplamente socializadas” (Regina Becker-Schmidt), isto é, são igualmente responsáveis pela família e pela profissão, mesmo se agora são liquidados os trabalhos de reprodução cada vez mais profissionalizados, por sua vez também por mulheres. (Scholz, 2016)

O que vimos na Armênia parece ser antes um alargamento da esfera pública (mercado) ainda que de forma bastante arbitrária e descaradamente exploratória, mesmo que essa exploração não necessariamente acumule capitais, ou melhor, não abocanhe seu quinhão de mais-valia global e se sim, para que mais?

É esse o processo que Marx designou como transição histórica da subsunção 'formal' para a subsunção 'real' da actividade produtiva sob o capital. No seu decurso, as técnicas, disposições dos meios de produção, organizações de processos, etc., são adaptadas, ou seja, alienadas da sua finalidade ligada à satisfação de necessidades no sentido da produção de bens de uso" (ibidem, 289 [259]). Isto significa concretamente: "A inovação dos processos refere-se a ramos produtivos já existentes ou transformados pelo capital. Na medida em que são submetidos à 'subsunção real', ou seja, as suas técnicas tradicionais pré-existentes são substituídas por técnicas capitalistas, também o seu procedimento de fabrico é afectado pelas inovações permanentes; e não só a técnica propriamente dita, como também os processos de organização ou comunicação. Se, nas industrializações de base do século XIX, a ênfase incidia ainda no aumento do recurso às máquinas mecânicas, no século XX, a partir da segunda revolução industrial ('taylorismo', 'fordismo'), a inovação deslocou-se crescentemente para o afiamento dos processos produtivos; não só pela famosa linha de montagem e pelas técnicas de organização do trabalho, que começaram a transformar os seres humanos em robôs, mas também com recurso a máquinas- 
ferramentas e logo, também, a técnicas de comando, etc. Esta chamada 'racionalização' causou um surto de produtividade monstruoso” (ibidem, 290 [260]). Este mecanismo compensatório da “expansão interna” do capital consiste, portanto, na "poupança maciça de dispêndio de trabalho ou de energia do trabalho humano por produto". Isto "também atingia ramos produtivos que, até então, tinham estado organizados na sua estrutura interna de um modo essencialmente artesanal, mesmo que já fossem objecto de uma concentração semelhante à de uma fábrica” (ibidem, 291 [260]), o que se mostrou claramente na produção em massa de automóveis, frigoríficos e outras coisas. (Scholz, 2016)

Aqui as teorias do imperialismo e os possíveis oásis de acumulação primitiva, como não simultâneos à valorização do valor desse tempo vivido, mostram-se já defasadas com a subsunção formal realizada na empresa transnacional capitalista. O “ajuste espacial” não mais como fronteira ou como limite fetichista do salário natural, aquele em que o trabalhador idealmente pode escolher entre vender sua força de trabalho ou virar produtor. A selva contemporânea é outra e já não se trata de desbravá-la, mas sim da corrida pela sobrevivência através de crédito, oásis em meio a tantos desertos de rentabilidade. A materialidade ou valor de uso podem muito bem ficar às traças, os helicópteros que jogam alimentos aos subsaarianos subnitridos pode não arrumar financiamento, mas os grãos continuarão a existir e de sobra ${ }^{131}$. Nesse ponto de crise de acumulação e pseudo resolução por ajustes espaciais é que entra a ideia de sociedade acumuladora de barbárie. Situada no contemporâneo momento de crise e queda absoluta de massa social de mais-valia, a sociedade passa a acumular barbárie através da mobilização de todos pelo fim-em-si do dinheiro sem substância de valor atrelado a um castelo de cartas do capital dos “créditos incobráveis” e “dívidas estatais incumpríveis”, de acordo com Scholz logo abaixo. Ponto importante de ressaltar é o papel da indústria de armamentos, negócio que mais movimenta dinheiro no capitalismo mundial, como a esperança da valorização ao custo da guerra civil mundial que a cada dia acumula novas barbáries.

O capitalismo atinge o seu clímax quando a expansão interna é atingida e ultrapassada pelo desenvolvimento das forças produtivas. Então a queda relativa da taxa de lucro transforma-se numa queda absoluta da massa social de mais-valia e portanto de lucro, esbarrando assim a valorização do valor supostamente eterna na sua desvalorização histórica. (...)

A acumulação alimenta-se desde então cada vez menos da substância de trabalho real passado e cada vez mais da antecipação de trabalho imaginário futuro. Investimentos e empregos sem qualquer base real são financiados por uma dívida global sem precedentes e pelas bolhas financeiras daí resultantes. ... Todavia, apesar das aparências temporárias, aqui não se acumula capital, como se viu na indústria de construção de muitos países após o estouro das bolhas imobiliárias. ... Após um encadeamento cerrado de crises financeiras, que nos últimos trinta anos abalaram países e sectores económicos isolados, o crash financeiro de 2008 assumiu pela primeira vez uma dimensão global. O rompimento das cadeias de crédito coloca na ordem do dia o grande surto da desvalorização. Foram os Estados, já por si altamente endividados, que impediram o

131 “Embora todos os recursos humanos e materiais estejam disponíveis, partes crescentes da população mundial vêem cerceadas e negadas as condições de vida mais elementares. Até os magros e vergonhosos fornecimentos de ajuda material a zonas de fome e de catástrofe têm de passar pelo buraco da agulha da 'financiabilidade' e fracassar nesse empreendimento, por não alcançarem volume necessário. (...) A administração democrática das pessoas converte-se numa burocracia de morte e decide sobre o 'valor da vida' do material humano, de acordo com a sua utilidade ou inutilidade prática pra o moribundo fetiche do capital.” (Kurz, 2012: 370) 
início da avalanche, por meio de injecção maciça de crédito adicional e emissão monetária ... As dívidas estatais incumpríveis somam-se aos créditos incobráveis dos mercados financeiros; aproxima-se a fusão nuclear do sistema de crédito. O futuro capitalista já consumido tornou-se presente. (Scholz, 2016, grifos nossos)

Nesse presente futuro, entre os tantos saltos mortais da mercadoria, se apresenta a acumulação de barbárie baseada na pseudo acumulação sobre o “outsider” - como se a mobilização geral não tivesse coberto o globo por inteiro. Para além de cobrir o globo com empregos e estágios, essa mobilização o faz também por meio de atividades dissociadas do valor tidas como "virtudes femininas” (Kurz), como também por meio de educação, de programas estatais e bolsas sociais, de encarceramento em massa, de ongueirismo ou ainda de prestação de serviços. Assim, embora todos os esforços estejam voltados à mobilização de todos para a valorização do valor, a concorrência do capitalismo atual recoloca as mais modernas inovações tecnológicas com vistas à ampliação produtiva que, contraditoriamente, incorrem na diminuição do valor produzido por unidade de mercadoria (fenômeno associado à queda tendencial da taxa de lucro). Restam às pessoas descartáveis ao processo de produção, a cada dia mais trocadas por máquinas e robôs, vagar entre turistas e guerras, entre oásis e desertos de rentabilidade (Kurz, 2005). As atuais hipóteses de colonização topam com guerras e fronteiras territoriais onde morrem e se violentam populações em lugares não-rentáveis mesmo com a indústria bélica dos top 10 da Otan envolvida; ou aqui nos lados das Terras Indígenas contra as commodities agrícolas, o mercado de futuro se territorializando no campo brasileiro do capital internacional do agrobussiness a martirizar populações indígenas. Um outro colonizável - como que por alguma mágica se pudesse fazer D-D' - aparece como sustentação moral da barbárie em suas acumulações. Para que mais?

O lastro do dinheiro há tempos é a bala, a bomba, como dizia Kurz e parece que já no tempo das revoluções militares que romperam com os feudos da Europa ocidental ${ }^{132}$ ou em na situação da Primeira Guerra Mundial quando se suspendeu o lastro-ouro das moedas européias. São momentos da acumulação de capitais pela expansão do financiamento em que se consolida em uma ficção, se cria liquidez, dinheiro em circulação, mas sem substância de valor produzida pelas exploração do trabalho nos desertos de rentabilidade. Desse modo, em ocasião de crise financeira todos querem resgatar seu capital na forma do dinheiro para mais uma rodada canibal de reordenamento dos capitais e mercados, quando os desertos da rentabilidade ficam sem liquidez, os Estados compram mais dólares para abaixar o câmbio e conseguir ter alimento para a população supérflua em nome de maiores e impagáveis dívidas. Somos o sujeito automático que insiste em dar crédito para a sociedade do trabalho em ruínas e sem substância.

132 Robert Kurz aborda esse assunto em detalhes em seu último livro "O dinheiro sem valor” e de maneira bastante mais curta em “O estouro da modernidade: com tostões e canhões”. 
Roswitha Scholz (2016) afirma que "as hipóteses de colonização são assim em Dörre transportadas para as mulheres, migrantes e outros “outsiders” de modo de facto forçado, já quase um pouco relutante, sendo que se pretende que a oposição de classes continue a ser sempre o verdadeiramente decisivo". Haja visto que a mulher galgou seu espaço em postos públicos, prestação de serviço e outros trabalhos de menor prestígio social, mas seguem minoria em postos de comando e/ou liderança ao mesmo tempo em que ocorre alargamento das atribuições relativas à esfera privada e do trabalho doméstico, que ainda segue sendo uma atribuição 'natural' das “virtudes femininas” (Kurz, 2000). Parece que a renovação ideológica da modernização retardatária 133 hoje se mostra no ilusório "pulo do sapo" que o empreendedorismo social prega como se a modernização pudesse usar atalhos e evitar "etapas” do desenvolvimento da economia da "riqueza nacional abstrata” (Kurz, 1992: 70) na contemporaneidade pós-catastrófica. Esse processo de subjetivação fetichista retardatário que pode ser acompanhado a par e passo na Armênia não garantiu nenhum espaço menos hostil às mulheres, pelo contrário, parece até reforçá-lo. Não é nada fácil, e mesmo conversando, vivendo três breves meses (cheios de visitas às igrejas do país) não conseguimos dimensionar ainda uma reflexão razoável sobre a importância da Igreja Apostólica Armênia no âmbito dessa questão social da relação do valor-dissociação em suas particularidades armênias.

133 Como foi mostrado pelas anotações sobre a palestra baseada em Schumpeter pela concepção de leapfrogging, mas também pela teoria dos sentimentos morais de Adam Smith! 


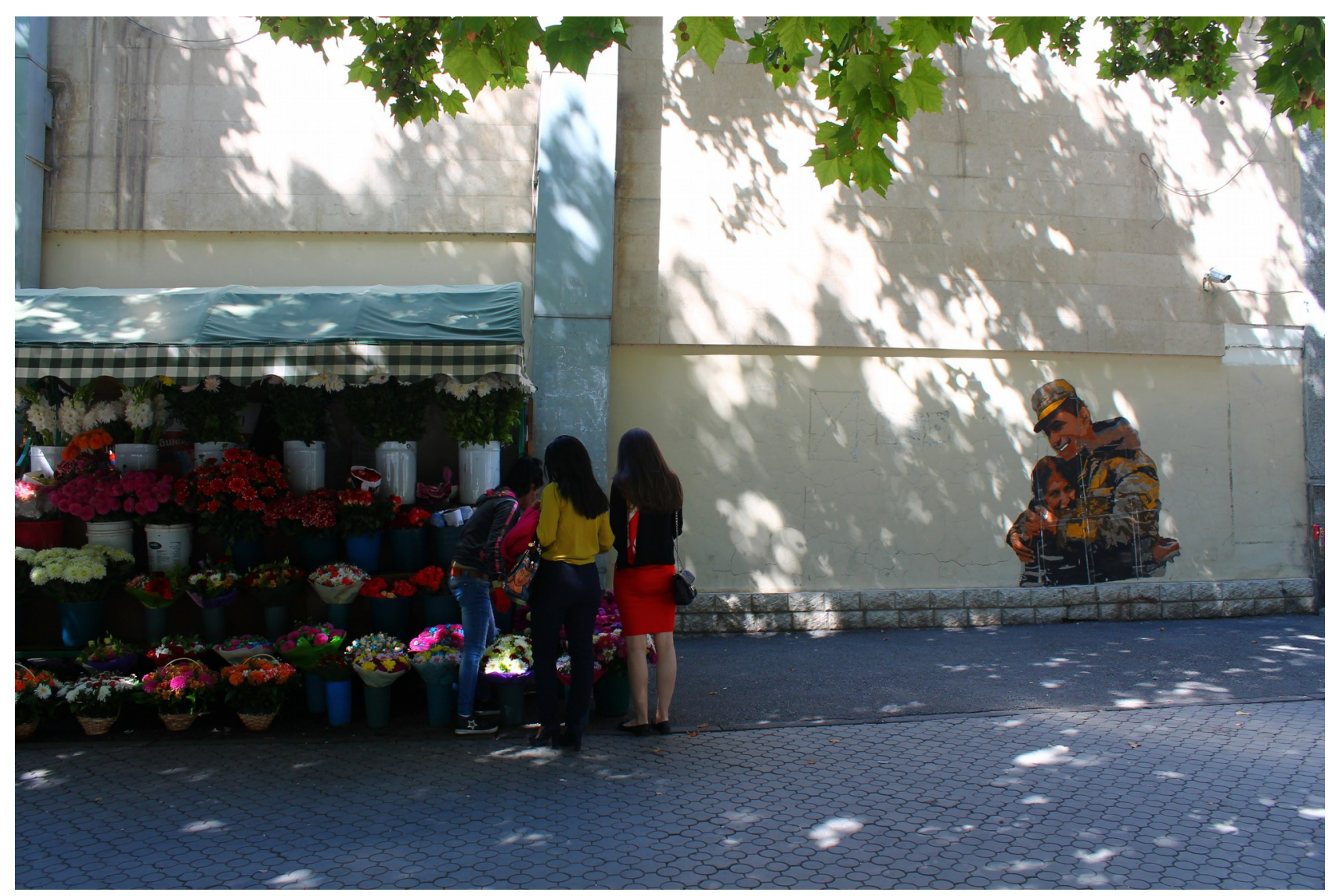

Foto 21 - Na capital Yerevan representações da guerra estão em toda parte. Atual Avenida Mesrob Mashdots, rebatizada depois do colapso soviético quando então ganhava o nome de Avenida Lenin. Marina T. Machado em 26/09/2016.

O espesso caldo da tradição é engrossado por diversos ingredientes conectados entre si: um ressentimento consciente de quem foi vítima de um genocídio não reconhecido pelos seus próprios vizinhos, uma retidão moral ancorada pelo orgulho religioso de ser a primeira nação cristã do mundo, uma modernização lenta e morosa que ainda engatinha e é própria das ex-repúblicas soviéticas e, por fim, um ethos de guerra constantemente reforçado pelo atual conflito em Nargorno-Karabakh. A somatória desses elementos garante e reverte-se em prática sociais androcêntricas particularmente armênias.

Algo que soa muito estranho é esse ethos de guerra que aqui é alimentado das mais diversas maneiras; desde os clipes musicais voltados ao conflito de Nagorno-Karabakh, passando obviamente pelo serviço militar obrigatório de dois anos, o ódio racial e religioso contra turcos e azeris (tido muitas vezes somente como turcos), que também é fomentado dos lados de lá da fronteira azeri ao que parece. A guerra move e evoca os sentimentos mais lamentáveis na sociedade do valor-dissociação: racismo, intolerância, dogmas, soberba, soberania. Não raro encontrar com uma pessoa hayastantsi (nascida na Armênia) que entende que tudo que é haykagan (coisas produzidas na Armênia) é melhor, mesmo que não tenham ultrapassado as fronteiras uma só vez; 
noutros casos, conhecem mas não se convencem do contrário. Muitos se ofendem com crítica tais e rebatem: "mas todos os países têm problemas”. A ideia de identidade vinculada à diferenciação aqui ganhou cores ainda mais fortes. Laranja, ou tsiranaguin (cor de damasco), como preferem os mais orgulhosos, o vermelho sangue encarnado em dinheiro e guerra, o azul da trégua impossível do terror que é o totalitarismo econômico (Kurz, 1999) instaurado pela guerra de 1914. Seriam essas as cores dos “jovens coloridos” que a próxima entrevistada nos contará?

Há dois dias tive uma conversa com um rapaz nascido na Jordânia, de família armênia, que estuda algo como desenho gráfico na Yerevan State University desde 2014. Ele se demonstrou inconformado com o "brain wash” do nacionalismo armênio e foi bastante lúcido ao retratar os velhos problemas do orientalismo e a forma como xiitas e sunitas são, ao mesmo tempo, mal interpretados pelo Ocidente, mas também usados como massa de manobra para que se mantenha instável a situação na Síria, Iraque e Golfo Pérsico. Falou também que a criação do Estado de Israel pode ser comparada a um hóspede hostil que se apodera da casa e rechaça o hospedeiro ao invés de conviver. Hostile with the host. 


\subsection{6) Entrevista com Lilit}

Entrevista com Lilit Gizhlaryan, historiadora armênia de 23 anos, realizada no dia 25 de novembro em Yerevan, no local de trabalho da entrevistada. A conversa foi feita em espanhol e aqui está transcrita e traduzida ao português com o intuito de preservar as expressões mais próximas ao que foi dito originalmente. Praticamente toda a entrevista traz referências ao que foi relatado ou teorizado ao longo dessa segunda parte. Por isso optamos, como no caso das duas longas entrevistas da primeira parte do texto, por expô-la inteiramente, somente dando títulos nas divisões para salientar temas, como Brecht em "Conversas de refugiados”, e algumas notas comentando ou contextualizando o que nos diz a pessoa entrevistada. Esta entrevista ao final da segunda parte não deixa de conter também certa fé de que para quem seguiu linearmente até aqui o percurso da exposição é possível interpretar e relacionar o que foi dito pela entrevistada com o que foi exposto anteriormente. Mais cor e contradição ao argumento.

\section{I) Identidade aqui não é problema/ Os medos da diáspora/ Pura armenidade spyurqhay vs. Sovietização hayastantsi}

Lilit: Bom quero começar primeiro que aqui na Armênia creio que, por que temos sim um país, temos a Independência e tudo isso e sabemos sim somos armênios não temos o problema de identidade de ser armênio. Não está como na diáspora que não buscamos de onde viemos, as raízes e tudo isso porque dizemos que somos armênios e já está, não? O problema é um pouco diferente aqui e por isso não... faz alguns anos que comecei a ver de minha família. Porque antes, quando perguntava a meu pai, (ele) dizia: “e por que queres saber?” Assim que eu nasci em um povoado muito, muito pequeno próximo da fronteira do Azerbaijão e eu sabia que não somos dali porque o cemitério de meus bisavós não estava ali. ${ }^{134}$ Meu avó sim, sabia que estava enterrado aí, mas não meu bisavô e sempre tinha a pergunta: De onde vêm? Mas ninguém sabia, ninguém. Tinha uma história geral do povoado de onde vieram, mas não especificavam, assim que comecei a perguntar às pessoas, aos mais velhos que sabem em geral de onde vêm e encontrei que vieram de NagornoKarabakh, então não era esta zona, era zona de Nagorno-Karabakh e as rotas eram mais que Nagorno. Eles haviam chegado da Pérsia e antes de Pérsia estavam no que é agora Armênia do oeste ou Turquia, não? Assim que não sei muito e ninguém sabe exactamente de onde e porque

134 Sobre isso Gagnebin nos recorda que túmulo e signo são em grego a mesma palavra, o que para ela "é um indício evidente de que todo o trabalho de pesquisa simbólica e de criação de significação é um trabalho de luto. E que as inscrições funerárias estejam entre os primeiros rastros de signos escritos confirma-nos, igualmente, quão inseparáveis são memória, escrita e morte” (Gagnebin, 2006: 45). 
decidiram a Pérsia e depois a Nagorno-Karabakh e depois vir ao que é hoje em dia Armênia, norte de Armênia. No se sabe muito, sei que meu avô da parte de meu pai foi um "smith", como se diz...? Artur: Ferreiro.

Lilit: Sim e minha avó muitas vezes me disse que, bom, vieram de Kars ${ }^{135}$ porque se lembra de como sua mãe sempre falava de sua bisavó que vivia em Kars, assim que vêm desde lá, mas de novo lamentavelmente a gente não busca essa identidade. Já se esqueceram sobre isto e eu quero dizer lamentavelmente. As histórias de hoje e do Genocídio eu conheci de minha vizinha que agora tem 103 anos e ela sempre falava de como mataram a seus pais e ela tinha que chegar aqui à Armênia despois teve que casar-se aos 10 anos, a menina, assim que, bom, já isto é sobre a família e o Genocídio, de onde vêm as famílias.

Artur: Esta señora de 103 (anos) é parte de sua família ou uma conhecida?

Lilit: Não, para mim não, é conhecida, minha vizinha no povoado.

Artur: Se casou com 10 anos?

Lilit: Sim.

Artur: Com?

Lilit: Com alguém do povoado que não era da Armênia do oeste, não era sobrevivente do Genocídio, mas alguém local.

Artur: (...) outra pergunta relacionada com isto que são as diferenças em termos ideológicos e de identidade entre os "hayastantsi" e a diáspora?

Lilit: É diferente. Bom primeiro falei que...e muitas vezes sempre notamos que aqui em Armênia temos, por exemplo, algumas coisas na cozinha que em Hayastan nós sabemos como fazê-lo, mas a gente da diáspora o sabe melhor, por exemplo, essa sopa, não sei...essa canção, tal e qual. Porque creio que aqui não tivemos este medo de que podemos perder-nos ou o medo de perder a identidade e a pátria, não sei. Mas na diáspora sempre tiveram esse medo. Por isso puderam conservar melhor em alguns aspectos que aqui em Armênia e creio que isso também surge a diferença entre a mentalidade porque o desenvolvimento foi diferente e já depois do Genocídio em desenvolvimento tivemos a União Soviética que, eu creio que para muita gente da diáspora não se entende, não

135 O romance "Neve" de Orhan Pamuk tem como o foco narrativo a vida de um turco de nome Ka que viveu em Frankfurt por alguns anos e volta à Turquia, mas não para a cidade natal Istanbul, mas sim para a quase fronteiriça cidade de Kars, que para os armênios é uma espécie de patrimônio histórico da Igreja Apostólica Armênia pois a 40 km desta cidade estão as ruínas de Ani, “a cidade das mil igrejas” que fora capital de uma das muitas transhistóricas armenidades. A neve, tema que vai e vem nas desventuras da personagem Ka em Kars, foi para nós um impeditivo de por Kars e Ani passar em nossa viagem pelo norte da Turquia dias depois dessa entrevista. A decadente Kars do romance, muitas vezes descrita sob neve por Pamuk, vive tempos sombrios envolta em uma onda de suicídio de jovens mulheres que à primeira vista tem relação com a polêmica sobre o uso de hijab (manto sobre os cabelos) como uma espécie de conflito frente a “ocidentalização da Turquia”, mas vai para muito além, o pêndulo kemalista, militar e islâmico que move as personificações políticas na sociedade turca é habilmente costurado na trama e seus conflitos da personagem que nos é apresentada como um amigo pessoal do autor. As casas vazias armênias são abordadas algumas vezes no romance. 
entendem porque de as coisas que fazemos aqui e a maior parte é porque aqui tivemos a União Soviética que mudou muitas coisas na mentalidade e eu creio que a diáspora está sempre um pouco mais crítica, não sobre os armênios, os "hayastantsi" que estamos aqui, da língua que usamos muitas palavras em russo que queremos as fronteiras abertas com Azerbaidjão ou com Turquia, por exemplo. Encontrei a uma senhora no ano passado do Uruguai que dizia: "não foram teus avós que foram mortos no Genocídio, claro que queres a fronteira aberta”, mas como pode é algo tão vergonhoso, não?, para eles o que queremos aqui. Eu lhe disse: "senhora, não é você que vive aqui em Armênia”. Eu noto cada vez que seria melhor para a economia e tudo isto. Assim creio que está aqui e surge a diferença e que aqui em Armênia temos muitos outros problemas que cremos que são mais urgentes e mais importantes para a gente que vive aqui que, por exemplo, se vai Obama dizer a palavra genocídio ou não, ou vai o mundo reconhecer o genocídio ou não. Eu creio que aqui especialmente aos mais jovens, para os mais velhos não posso dizer isso porque a geração de meus avós e de meus pais também é para eles importantíssimo e cada vez, pelas tevês e tudo isso, escutamos a ver o que diz Angela Merkel ou não sei, se dizem a palavra ou não, mas creio que para os jovens isso não é a parte mais importante. Nós sabemos que o Genocídio sim há ocorrido, mas não nos importa se alguém de elite política do mundo vai reconhecer-lho ou não porque, enfim, sabemos que eles também o sabem, é uma coisa política e sabemos que as forças que necessitamos agora são para outras coisas, desenvolvimento do país em geral e eu creio que aqui temos esta ideia que se somos os sobreviventes por isso queremos criar um país mais desenvolvido e melhor que nossos antepassados falecidos, bom, que lhes mataram, eles não tiveram e cremos que para a memória deles temos que fazer mais isto que é tomar as bandeiras armênias e queimar as bandeiras turcas.

Quero acrescentar algo sobre isto porque temos também outro aspecto da União Soviética. Quando queriam matar a identidade da gente em geral porque não eram armênios, não eram russos, com sua cultura com sua história e tudo, mas era uma gente soviética que não teve nada da cultura e da história sua e creio que por isso a geração de nossos pais, todavia, tem este aspecto, por exemplo, quando queremos ir a uma igreja ou não sei, conhecer esta cova que é a quinta maior do mundo e está em Armênia, meu pai sempre me diz "por que te interessa, por que queres ir?" Eles não entendem, para nós é importante conhecer a cultura, a história e os monastérios também é uma parte de nossa identidade e eu creio que os jovens e eu creio que tu também, não sei se foste aos bailes em Naregatsi ${ }^{136}$ [Art Institut], os bailes armênios. Isto foi um movimento incrível, antes não sabíamos nada dos bailes porque durante a U.S. ninguém, não os importava tinham algumas coisas que eram para a gente soviética, os bailes não, que eram como no Quirguistão e na 136 http://www.naregatsi.org/index.php?section=0\& 
Armênia, ninguém tinha algo cultural específico e agora há gente que quer de novo tomar os elementos da história e mostrar-nos que sim, nós temos e eu creio que uma dessas coisas foram os bailes que temos uma pessoa que foi na guerra de Nagorno-Karabakh, bom, ele estava aí também e depois chegou e trouxe os bailes e agora os jovens encontram um ao outro e que fazemos? Vamos a bailar no metro, nos ônibus, nas ruas, sempre temos "flashmobs". Eu creio que é algo muito importante também de ideologia e identidade.

\section{II) Os jovens coloridos/ A palavra nacional/ Sobre queimar bandeiras}

Artur: Então, o ponto de vista político-estratégico, a geração mais jovem tem outro olhar?

Lilit: Seguramente, eu creio que a geração que temos, é só minha opinião, mas creio que muitos dos jovens vão a estar de acordo comigo que dizemos a geração de Bagramian, de Eletric Yerevan. Ano passado que tivemos os protestos de Eletric Yerevan eu creio que algo mais surgiu aí e foram os jovens muito, em Armênia dizemos, "coloridos”, "os jovens coloridos” que são crianças e jovens muito inteligentes e muito bons, muito maduros que já sabem o que querem fazer com esse país. Têm a ideia que é respeitar a constituição, que respeitam seu país e a independência que tem conseguido ter depois de tantos séculos, creio que sabem do valor da independência e é mais importante que nossos pais que tem a experiência, mas...

Artur: Por outro lado não acha que isso traz um sentimento nacional muito forte e que há aí também um pouco de perigo, não sei...

Lilit: Agora estou lendo um livro sobre Nagorno-Karabakh, “The Black Garden” que escreveram, bom o autor é ingles britânico e é muito neutro, não quer entender porque estão em NagornoKarabakh, porque temos esse conflicto e porque os armênios não querem ceder e tampouco o querem os azerís e uma coisa que notei aí é o uso da palavra nacional porque a usa de modo muito mal e eu não entendo porque a palavra nacional tem que ter esse sentido. Eu creio que a palavra nacional, nacionalista, de outro modo não é a palavra fascista, são diferentes. De fato eu creio que é algo muito bom e creio que as diferenças são muito boas, assim que é só uma coisa de respeitar as diferenças que devemos alcançar, mas nacional eu creio que é algo muito bom, me encanta Armênia, claro e eu creio que é lógico que goste mais do que, por exemplo, Geórgia o Azerbaijão. Não porque são melhores ou piores porque isso é ser meu e eu creio que, igual é logico que os azerís, os georgianos, os brasileiros lhes goste mais Brasil ou não sei, eu creio que é lógico e creio que algo que devemos com isto ter o respeito. Não dizer que se é Armenia é melhor, temos tais coisas, monastérios, etc., mas também respeitar que, se tu és brasileiro, a ti te gosta Brasil é 
melhor porque é teu. E eu o respeito, mas eu também tenho isso e estou orgulhosa por coisas que temos aqui... entendes o que quero dizer?

Artur: Sim, sim, sim, mas muitas vezes parece que chega a, não você, mas às pessoas que conhecemos, não só jovens... um sentimento muito forte que muitas vezes se mescla com ódio com outro que a identidade está marcada pela diferença... "porque sou armênio, não sou azerí, não sou isso ou aquilo".

Lilit: Sim, sim, entendo o que queres dizer, mas creio que é outra coisa. Não são esses jovens que digo que são tão bons e maduros, que queren saber mais de sua cultura, não, eles tambén viajam, também sabem de outras culturas. Isso que queres dizer tu, eu creio que é a gente que tem sempre queimado as bandeiras, porque isto é un exemplo não específico de queimar as bandeiras no dia 24 de abril quando marchamos. Isto é do partido dos Dashnaks (Federação Revolucionária Armênia) que tem estado aí por dois séculos, não são os jovens da geracão de Independência, são os Dashnaks. Eu creio que isto é diferente e a geração de Independência, a geração que eu creio que vão a fazer algo nesse país são os que não têm partidos, não são parte dos Dashnaks nem dos Republicanos, não são nem pró-Europa nem pró-Rússia. São "temos este país, queremos este país e queremos converter em um lugar bom para todos" para que todos, bom, os direitos humanos $e$ tudo estejam em boas condições para os armênios, para os azeris que vivem aqui, os gregos, para todos. Eu creio que é outro aspecto esse nacionalismo.

Artur: Sim, em outra perspectiva os Dashnaks são uma forma de nacionalismo muito latente.

Lilit: Sim, eu creio que a geração de Independência estas crianças, estes garotos, os jovens não têm nada que ver com isso, eu creio que são distintos níveis de nacionalismos e como o entendem.

\section{III) Russo sai, armênio fica e a sensação de poder através de protestos}

Artur: Falaste de Eletric Yerevan, não sei o que é isso, podes falar?

Lilit: Eletric Yerevan era no ano passado, aquí temos “nuclear power plant”, não? Para a eletricidade nuclear como se diz e isto pertencia a uma companhia russa que estava em dívidas por corrupção e tudo e queria elevar os preços de electricidade para os armênios e nós temos 100\% da rede de electricidade, temos aqui em Armênia e aqui é mais caro que na Geórgia e nós o vendemos à Geoógia. As pessoas não entendiam porque isto deve ser assim, claro, pelas dívidas, pela corrupção e tudo. Assim que quando queriam elevar os preços as pessoas saíram nas rua $e$ disseram que não queriam isto. Era um protesto pacífico e eu também estava aí no primeiro dia, estávamos no asfalto, nos sentamos e às 02:00 am eu me fui, mas a gente todavia ficou aí em [Avenida Marshall] Bagramian, na rua Bagramian e às quatro, cinco da manhã chegou a polícia com (canhões de água) e, bom, atiraram nos ativistas e depois, no dia seguinte, toda gente saiu nas 
ruas. Tivemos mais de 10.000 pessoas na rua, mais pela injustiça da polícia, também claro pelos preços, mas nos deu raiva como era um protesto pacífico e veio a polícia e faz com a gente, aos jovens que estavam aí e era algo insuportável. Por duas semanas toda a rua estava fechada pela gente, mais de 10.000 nas ruas lutando aí também e o resultado que, bom, venderam esta companhia e agora ao menos pertenence a um armênio. Dizemos “não se mudou muito”, se vês os resultados nada...é um armênio, pertence a ele já não é a companhia russa que estava em corrupção e tudo, é armênio. Para os números não, é mais ou menos igual, mas era mais importante para a mentalidade que era a Armênia que desejamos viver, de igualdade que todos, bom, muito humanos, muito bons...

\section{IV) Identidade e lugar/ Hayastan e diáspora/ Ethos de guerra e a pós-castrófica região de Nagorno-Karabakh}

Artur: Podes falar um poquinho mais sobre o que querem os "jovens coloridos" e, por exemplo, a representação muito marcada de Genocidio na diáspora...o que elegem os jovens, o que está sempre sendo repetido na diáspora Genocídio... “Remember and Demand”...

Lilit: Bom, esse "Remember and Demand” a ninguém na Armênia, Hayastan, não nos gostou a ideia nem como fizeram algo tão comercial como isso aqui, mas como vejo em diáspora isso era algo como "nossa flor" e tal qual. Aqui não era assim, mas eu creio que outra coisa que começa a diferença da mentalidade dos jovens em diáspora e em Armênia é o caso de Nagorno-Karabakh porque agora para nós é o que vemos cada dia, que há disparos na fronteira, que a gente morre. Assim que, para nós é algo mais importante que o Genocídio, bom, não mais importante mas que vivemos. Presente, sim, mas presente e que são nossos amigos e tudo e que o Genocídio que passou a não sei, um século. Por isso eu creio que é uma coisa que distrai nossa atenção o Genocídio enquanto que a gente de diáspora, eu creio, que ainda não entendem a realidade, o que está passando aqui, o conflito, e por isso para eles ainda o Genocídio. Além disso, claro que foram eles, sues antepassados que tinham que mudar o lugar, mas para nós, os armênios do leste, que dizemos aqui nunca tivemos este problema de mudar o país, perderam as casas e tudo. Assim que eu creio que é logico mas é diferente, diferença de mentalidades que temos. Como é dito: aqui não temos medo de perder a identidade porque todos sabemos, vivemos em Armênia, somos armênios, temos o passaporte armênio, enquanto que na diáspora tu vais a uma escola, e eu creio que a língua é a coisa mais importante para a identidade ${ }^{137}$, tu vais a uma escola não falam em sua língua, em que os pais dos antepassados haviam falado, assim que medo é mais não é o perigo de perder a 
identidade. Por isso aqui em Armênia estamos mais tranquilos e podemos concentrar-nos em coisas que são, que creemos que são mais importantes como o governo e as coisas internas, enquanto que para diáspora não sei, não conheço a muitos que falem o que queram falar sobre as coisas que estão passando aqui no governo porque creem que não é algo bom falar sobre isso ou do dinheiro que há...ontem foi o dia do telemarathon, não? E os armênios...

Artur: Para onde foi esse dinheiro?

Lilit: A Karabakh deve ir todo o dinheiro 15 milhões de dólares ou euros não sei, a NagornoKarabakh e hoje já notei meus amigos por Facebook todos diziam em inglês "por favor que não enviem mais dinheiro ao governo" enquanto que os diásporas que vejo e leio seus status todos estão tão orgulhosos de haver podido ajudar ao menos um pouco ao país, enquanto que aquí dizemos que não, não há...

Artur: Não se sabe onde vai ficar?

Lilit: Sim, exato. Eu creio que é uma das diferenças também ou o que passou em julho com o protesto. Não sei, todos aqui sabemos o que queremos, mas não houve nenhum tipo de nem anúncios nem nada de diáspora, mas estou segura que se houve algo sobre Genocìdio todos haviam ido pelas ruas de Los Angeles, de não sei que com a bandera mais larga de Armênia e aí enquanto quando é algo de aqui...não quero dizer não lhes importa, mas creio que não entendem que está passando.

Artur: Eu vi a diáspora do Brasil, de São Paulo, tem uma cobertura bastante, creio relativamente ampla e que passou também notícias dos protestos de julho agora, mas há notícias mas não muito detalhadas e se podes dizer que passou, quem eram as forças políticas que estavam pelejando...?

Lilit: Antes de começar isto quero acrescentar algo, não é que a cobertura é má. Agora estou orgulhosa de dizer-lo que temos alguns periódicos aqui em Armênia que são muito livres que sempre falam o "hetq”, a "libertad”, “civilnet ${ }^{138 ”}$ que dizem o que está passando no país e mais bem é algo eu creio que a gente de diáspora tem esta imagem idealizada do país, da Armênia, da pátria que muitas vezes lhes custa saber que coisas que não estão tão ideais, que não é tão boa, que há problemas também, tal e qual. Por isso não quero não querem escutar, não querem ouvir, não é que não há cobertura, mas muitas vezes, bom, eles não gostam de ouvir e entendo também, é lógico porque por muitas vezes sempre tem falado desta Armênia que querem, que é tão bonita, que tem o damasco (apricot) que é melhor do mundo e alguém vem e diz: sabes os direitos humanos, que tens prisioneiros no cárcer, prisioneiros políticos em cárceres tudo que não são coisas boas para querer ouvir. O que passou em julho nós ainda não entendemos o que era, mas era algo que

138 Os três sítios eletrônicos: http://hetq.am/eng/ ; https://www.azatutyun.am/; http://www.civilnet.am/ . 
mostrou para a gente que assim não se pode continuar, que o governo, que estamos em uma situação que o governo não faz nada, mas tomar o dinheiro, só tomar dinheiro da gente pelos impostos e tudo realmente não funciona como um governo. O que fez isto claro, não teve resultados, ainda [resultados] tão marcados que podemos dizer como o Eletric Yerevan de Bagramian, mas creio que joga com a mentalidade da gente porque todavia estamos em maioria da gente estão no nível soviético, não? Assim que são coisas muito pequenas, mas eu creio que é o início de levantar algo na mentalidade da gente para dizer que algo mudou.

Artur: As pessoas que estavam no protesto tinham uma organização ou foi algo mais espontâneo? Lilit: Não, tinha sua organização e dizem que, bom, é bastante grande, tem gente de diáspora que lhes ajuda, mas são só rumores não posso dizer nada concreto, mas eles que estavam aqui era o grupo, os veteranos que estavam na guerra de Nagorno-Karabakh faz vinte e mais anos, então, são gente inteligente, são gente que tem estado em posições também, depois da independência de Armênia, em posicões muito altas como o ministério de Defesa, Varujan?, não me lembro seu nome, mas depois se necessitas posso marcar. Varujan Avetisian, sim. Assim que é inteligentíssimo, ele quando fala e sabes que tem meta, que é lógico o que esta dizendo era um dos veteranos em Nagorno-Karabakh, assim que são gente que não, que são gente especial. Não sei, o fizeram por seu amigo [o general Vardán] Eguiazarian ${ }^{139}$ que agora é um prisioneiro político e tudo isso, queriam liberá-lo, bom, a ideia era liberá-lo, mas depois se converteu em algo mais que queriam também o renúncio do Presidente, o governo em geral, mas começou como algo para Eguizarian. Artur: Ao mesmo tempo o Presidente era combatente de Karabakh...

Lilit: Ah...não, quando perguntas à gente quem realmente, por exemplo, perdeu seus "legs or arms" 140 ...quando lhes pergunta a eles dizen: “é diferente”. Temos agora generais em Armênia que dizem que combateram na terra de Nagorno-Karabakh, mas quando lhes fala, eles já são gente que não, quiçá estavam aí, mas fizeram nada para este país, que são tontos, terríveis, terríveis e agora estão governando ${ }^{141}$.

Artur: Se utilizam da imagem de Karabakh...

139 Outro militar veterano de Karabakh e ativista opositor ao governo atual, Jirair Sefilian, foi preso em junho de 2016 por posse ilegal de armas. Em 17 de julho de 2016 manifestantes tomaram um posto policial de assalto e um policial foi morto e dezenas de manifestantes foram detidos na ocasião.

140 Pernas ou braços

141 Porto (2017) fala sobre essa passagem histórica: “em primeiro lugar, a independência da República do Karabakh foi declarada em 1994, mas a classe política que controlaria a região desenvolvera a sua trajetória precisamente na República da Armênia - o exemplo mais claro disso é o caso do primeiro presidente do Karabakh, Robert Khocharyan, que, imediatamente após o seu mandato, seria eleito para a presidência da Armênia. Esse tipo de trânsito dos homens políticos entre Estados independentes produz uma situação um tanto anômala e serve de fundamento para a argumentação de que os armênios não estariam sendo sinceros em sua luta por um Karabakh autônomo (Porto, 2007: 175-6). 
Lilit: Sim, sim, sim, assim que realmente Karabakh é outra coisa, não? Todavia não entendes como, porque, mas a gente, a gente ordinária, teve uma parte grandíssima na vitória...

Artur: Apoiaram, estiveram em conjunto com o exército, a tomada de Shushi...

Lilit: Sim, porque não tivemos nosso exército armênio, não tivemos nada porque era justo antes que Armênia saia da U. Soviética. Assim que não tivemos nada armênio, era a gente e meu tio e meu pai também. Meu pai no exército que todavia tinha só un ano, podes imaginar que estava passando em um exército de um ano? Meu tio foi como um voluntário e dizem que, bom, era a gente que o fazia, os russos e a gente nas posições altas, as pessoas...

\section{V) No future/ Imposto de guerra, guerra imposta}

Artur: Já que estamos falando desse conflito, podes dizer algo sobre a conjuntura atual, se há perspectivas para a resolução? Que papel que tem o Grupo Minsk, se ajuda ou não ajuda? Quais são as perspectivas para o futuro?

Lilit: Quando olha ao nivel da gente eu tenho muitos amigos que são azeris, eu nasci em um povoado que estava justo à fronteira e sempre podíamos ver de minha casa, se podia ver as casas dos azeris como tão justo, tão perto e sempre ouvindo as estórias de como os turcos, porque em armênio não usamos a palavra azeri, chamamos os turcos à gente de Turquia e do Azerbaijão e sempre ouvia as estórias dos turcos que cruzavam, chegavam em nosso povoado que ficavam para a noite na casa de meu avô, então, eu cresci em uma atmosfera que gente é gente em todos os lugares e eu creio isto; quando falas no nível da gente todos queremos a solução pacífica e ninguém deles querem disparos nem soldados que morrem aos 18 años é terrível, mas ao nível político não sei, todavia creio que a resolução não vai a estar na mesma posição como agora e eu espero que a gente entenda que é algo, é um absurdo e que pode coexistir, mas creio que não sei, não tenho muita esperança para o futuro próximo...eu sei que algum dia, seguro que algum dia espero, mas para o futuro não porque o conflito se usa por gente, por governos mais altos, por gente mais alta que estão em posições mais altas para seu dinhero, para suas armas e não vão querer renunciar...

Artur: Inclusive, muito interessante a Rússia que vende armas para dois lados...

Lilit: Sim, sim, claro e é algo, bom agora que, não sei se ouvistes dos 1.000 drams [aproximadamente dois dólares americanos] que é algo mandatório e os cidadãos de Armênia cada mês têm que pagar 1.000 drams para o exército, assim que é dinheiro é muitíssimo dinheiro se conta ao final do ano não sabemos aonde vai porque estes anos eu pago trinta porcento de meu salário aos impostos que dizem que vão ao exército e agora chegam e me dizem: "sabes, esse 
dinheiro não é suficiente" e temos que pagar 1.000 drams extra e, bom, não se questiona nada, têm off shores e tudo isso e quando querem por a atenção da gente em outra coisa sempre metem aos outros, à gente o conflito que nós façamos algo aí, que pelejemos e eles fazem suas coisas.

\section{VI) Sobre influência e dependência russa}

Artur: Agora creio que é bom pensarmos um pouco com Rússia depois do colapso soviético, a relação que há hoje e a influência que segue se é só influência se é dependência também. Como estas olhando para isso?

Lilit: Aqui também é muito importante e notável a diferença das gerações, eu falo com meus pais, a geração de meus pais eles muito... e também com sua cultura, a escola durante a U.R.R.S., durante os anos melhores, os anos de ouro da U.R.R.S. 1960 a 1970, assim que claro eles todavia querem que nos entendemos muito e a realidade quanto a economia nós dependemos muitíssimo de Rússia, mas depois há a mentalidade dos jovens o que passou com o pacto de gás. Agora não temos direito de comprar gás de nenhum país ainda que seja mais barato só podemos, devemos comprar de Gazprom $^{142}$. Ah, que temos Irã ao lado que diz que nos vai vender muito mais barato que a Rússia, então, somos esta geração que vemos esta parte de Rússia e não o que foi a U.RS.S., vemos a parte, bom, do exército russo que esta aqui agora a base russa que está em Gyumri, vemos que soldados ali e matam e, bom, claro que não todos o fazem, mas há esteriótipos que surgem e eu creio que nós já somos esta geração e o que se refere à influência, não? Disseste influência, especialmente cultural eu creio que a geração de Independência já não tem, nem o nível de língua e fazem alguns dias que, eu creio que era alguém da embaixada da Rússia aqui em Armênia ou era alguém do governo russo, que digo que todos os países pós-soviéticos devem ter como língua oficial russo também e isto era algo incrível aqui em Armênia, quiçá no [ano] 2.000 a gente diria "sim, por que não?” e a maioria da gente também estava bilíngue, mas agora dizem que "não, temos nosso país, é Arménia e a língua deve ser armênia”. Assim que o nível da língua até, não sei, música, a parte cultural que a influência já não têm.

Artur: Está ficando mais fraca?

142 A Gazprom é a segunda maior produtora de petróleo do mundo (8,3 milhões de barris/dia), imediatamente na frente da Cia Nacional de Petróleo do Irã (6 milhões de barris/dia). A empresa saudita Saudi Aramco aparece como a mais produtiva com 12 milhões de barris/dia. Atualmente a Rússia é o maior país produtor de petróleo do mundo e desde o final de 2016 os principais produtores de petróleo têm restringido os fornecimentos na tentativa de combater a pior queda de preço da commodity nas últimas décadas. A Organização dos Países Exportadores de Petróleo (OPEP) decidiu cortar 1,2 milhões de barris/dia durante seis meses iniciados em $1^{\circ}$ de janeiro de 2017, mesmo fora desta organização, a Rússia se comprometeu a fazer cortes. Fonte: Consultoria WoodMackenzie disponível em:

https://oglobo.globo.com/economia/os-reis-do-petroleo-veja-os-maiores-produtores-da-commodity-no-mundo-

20955478 acesso 07/07/2017. 
Lilit: Sim, eu creio que agora já vemos mais, ninguém, bom, meus pais sim, a geração de meus pais todavia seguem jornal russo, as notícias em russo e sempre também é algo um meio de lavar a mente da gente, não? Mas os jovens já não, já têm outros recursos para ver que está passando no mundo e não seguir as notícias russas, por exemplo, quando alguém põe que Putin isso que é tão bom e tudo...não, analisar e ver outros recursos e ver que há.

Artur: Bom, diferente para nós porque tínhamos esta imagem de que Rússia, depois que passou o colapso da União Soviética, não tinha tanta força, mas segue tendo, não sei como é em Verastán (Geórgia), vou ver um poquinho agora, mas...

Lilit: Verastán não, Verastán que vais a ver, notar é muito diferente.

Artur: Por causa da guerra...

Lilit: Sim, depois de 2008, essas são coisas que a gente diz, dizem "olha que passou com Ucrânia e com Geórgia que agora são mais pró-europeus, “western”, mas mudaram seus territórios é uma das coisas que dizem “Karabakh, não queremos perder Karabakh” e antes não temos que estar tão fiéis todavia à Rússia e se olhas de novo ao nível político-econômico todavia estamos muito, muito muito dependentes deles e esta mentalidade que é diferente.

\section{VII) Memórias de menina em tempos de escassez/ Orgulho e independência/ Igualmente pobres no comunismo das coisas}

Lilit: Eu tenho o privilégio de ser geração da independência e estou muito orgulhosa de dizer-lo, mas sempre, claro nos acompanham as estórias de nossos pais, de nossos avós sobre os anos da U.R.S.S. e claro para eles foi melhor. Se falas a qualquer pessoa que tem mais de trinta anos ou trinta e cinco anos ou quarenta anos te vão dizer que eram anos melhores, os anos da U.R.S.S. $e$ nós não os entendemos, não entendemos como alguém pudera viver sem independência sem ter algo seu, mas creio que quiseram porque a situação que agora temos aos oligarcas, que temos esse “rich” que cada dia é mais e mais, se comparas dizemos os anos da U.R.S.S. todos eram iguais, igualmente pobres e agora que não, não são iguais, há gente que sim são ricos, têm tudo e depois temos os pobres. Eu creio que é algo por isso, não têm essa sensação de igualdade, que em Arménia de hoje não temos. Igualdade e oportunidades também, por isso eles prefeririam que a U.R.S.S. se continuara, não sei. Depois vieram os anos obscuros que, como dizemos, e frios, sim, sim...eu não lembro muitas coisas desses anos porque eu nasci en 1993, bom, não me lembro muito só são estórias dos pais, como tão difícil era crescer, gerar. Me lembro só do pão, que era para nós tão importante porque não tínhamos muito e quando faziam o pão era como "ah, hoje é dia de pão”, nos reuníamos. O sorvete, noutro dia falei com meus pais e lembramos os anos que o sorvete 
era algo tão importante e tão, não sei, o podíamos comer quiçá só uma vez ao mês...e tínhamos essa vizinha que fazia sua vodka e sempre nos comprava sorvete com [o dinheiro da vodka] a vodka porque a gente não tinha dinheiro, não havia dinheiro e a avó mais pobrinha dos meninos do bairro, não? Claro que era muito, muito difícil, também a fila do pão que tinha gente que tinha dinheiro mas não havia nada de comprar e a fila as vezes, não sei, eram cinco horas para comprar 100 gramas de pão e nada mais porque não havia mais e também não podemos esquecer o terremoto que tivemos, assim que creio que eram anos muito difíceis. Era o colapso da U.R.S.S., era terremoto que matou quase 30.000 gente, eram 24.000 número oficial e chega a 27.000 mais ou menos. Isso e depois a guerra e toda a Independencia começou assim e eu creio que isso que temos agora és algo de estar orgullosa e também com o Presidente de Armênia que foi o primeiro Presidente depois da U.S., Levon Der Petrossian, falam coisas...não o conheço muito, não vivi quando ele era o Presidente, não me lembro muito dele, mas creio que era algo realmente muito bom, importante, não? Estar em uma posição tal quando não tem nada, nem tens um país e tem que começar tudo do zero ainda não do zero de nível menos de zero com o terremoto e tudo. Ruínas, tem que reconstruir um país em ruínas.

\section{VIII) Diferenças entre jovens do resgate cultural e os nacionalistas/ Oligarcas e suas marcas}

Lilit: Antes que comece vou te dizer há este grupo dos bailes que digo que os jovens ainda, não sei se têm um condutor, mas se reunem e bailam e para saber um pouco desta, para entender o que digo que a gente, os jovens de agora e os nacionalistas que temos tido são coisas diferentes podes ver aí porque aí, só sei se há respeito para outra gente porque essa gente nunca vai a queimar nada, não são como eles, mas ao mesmo tempo, estão orgulhosos do que têm e isso é que digo que não é mal.

Artur: Como resgate cultural...

Lilit: Sim, assim que se queres podes ir a Naregatsi [Art Institut] está perto do Vernissage.

Artur: Eu vi muitas vezes [as danças] em Gyumri e aqui também no dia 25 [de setembro, data da comemoração da Independencia da U. Soviética] havia uma roda de dança muito grande e com pessoas muito animadas, alegres e outras vezes coisas espontâneas dos jovens, dançando a dança tradicional e [a dança] pré-guerra para concentrar-se. Em Gyumri há grupos também que fazem reuniões semanais e tudo isso. Pessoas que aquí vieram por voluntários se juntaram. Porque agora creemos que são importantes essas coisas, que não podes ser armênio sem saber e tem a piada, dizem “não podes ser armênio ao bailar 'Kinka' dos georgianos ou 'Kinka' durante as bodas”. 
Agora não, tu não sabes bailar em armênio, não sabes o Kochari ou este ou tal? Agora não, deves saber-lo e eu não o vejo mal...o elemento melhor ao mundo.

Artur: Preserva algo muito antigo, muito interessante...agora me lembrei que nós temos um pouco de notícia, um pouco de história sobre o que passou em Rússia depois do colapso, em respeito da concentração de capitais que são os oligarcas russos, sim? E queria saber de você se passou algo semelhante aqui, se passaram os oligarcas russos dentro da Armênia se são oligarcas armênios? A concentração foi muito feroz, muito rápida na Rússia, como foi no caso armênio? Também escutamos nos 1990 do caso da máfia, de mercado negro...se passou algo como na Rússia?

Lilit: Bom, durante a U.R.S.S. e agora também Armênia é um os países pós-sovieticos mais homogêneos que temos, assim que, se refere aos russos aqui em Armênia ou se passou o mesmo aqui?

Artur: Se passou o mesmo em geral ou se também ocorreu de ter oligarcas russos em Armênia ou se são oligarcas armênios?

Lilit: Russos não diria que aqui temos, mas bem são os oligarcas armênios ${ }^{143}$ que temos, não me lembro de nenhum, bom, se houve alguém tão importante, mas não me recordo de ninguém tão importante, mas sim que temos nossos oligarcas armênios que tivemos também...bom eram a gente também no poder, não sei isto é algo muito pessoal, minha opinião sobre isto não posso dizer, mas quando ves os oligarcas de agora durante a U.R.S.S. e os ultimos anos da U.R.S.S. eram a gente que estavam os líderes dos movimentos, então não se fizeram como oligarcas ou como máfia e quando já lhes deram ou tomaran o poder, depois já e converterem pouco a pouco em oligarcas. Entendes o que quero dizer? Mas já estavam, já se converteram em oligarcas em seus lugares, em seus postos.

Artur: Tinham primeiro o poder pela grana e depois ocuparam as cadeiras de poder. Porque o que passou em Rússia, sei muito pouco, mas que escutei e li que compraram as companhias estatais a um preço muito baixo e começou a privatização que foi um bom negócio para eles.

Lilit: Sim, aqui também, aqui roubaram muito de, por exemplo, cobre, aqui em Yerevan houve o "tramway" aqui também tivemos até 1980/90, não? Mas chegaram e dizem que era Galoust [Sahakyan] que agora está presidente de parlamento ${ }^{144}$, que era ele que nos roubou e vendido depois e fez uma carreira disso. Assim que aqui também, claro, tem passado coisas porque era uma situação caótica, não pertencia a ninguém, mas ao mesmo tempo pertencia a todos, assim que

143 Entre os oligarcas destaca-se o Partido Armênia Próspera, liderado por Gagik Tsarukian, que forma o maior grupo de oposição ao Presidente Sargsian, filiado ao Partido Republicano da Armênia.

144 Sahakyan, filiado ao Partido Republicano da Armênia é o ex-presidente da Assembléia Nacional Armênia encerrou em 18 de maio de 2017 seu mandato iniciado em 29 de abril de 2014. Atualmente o cargo é ocupado por Ara Babloyan, filiado ao mesmo partido de seu antecessor. 
todos queriam tomar tudo que podiam e quem tinha a seu amigo ou alguém dos parentes em lugares, nos postos importantes, podiam sacar mais, todavia funcionava essa coisa a corrupção $e$ tudo que nos sobrou dos anos da U.R.S.S.

\section{IX) Entre os impérios persa e russo e sobre posição geográfica}

Artur: A Armênia do leste que esteve sob domínio persa durante quatro séculos, mais de quatro séculos y depois a Guerra russo-persa $1826-27^{145}$. Podes dar um panorâma sobre isso e depois as herenças do período persa e as herenças de Império Russo?

Lilit: Sempre tinha esta pergunta porque quando vemos os autores, cantantores, no sei a gente importante que temos que chamamos armênios, em geral a cultura sempre há estado mais desenvolvida na Armênia do oeste, hoje em dia Turquia. Sempre, aí temos mais monastérios, aí temos mais e sempre falávamos com meu professor sobre isso e me disse "sabes porque aí houve o mar” e o mar em general para desenvolvimento das civilizações é uma coisa muito importante. Assim que Armênia do leste, hoje Hayastan, nunca esteve em uma posição tão boa, tão desenvolvida, tão... nunca, especialmente Yerevan. Yerevan dizemos que é uma cidade de quase 3.000 años, uma das cidades mais antigas, mas não temos nada aqui, tal como vemos agora só começou em 1920, não? Quando chegaran os bolcheviques e é um dos argumentos da gente, que todavia permaneceu nos anos da U.R.S.S., que diz "e o que era Yerevan antes dos bolcheviques e o que temos agora tal como uma cidade”. Quando ves as fotos, por exemplo, de 1915 ou durante o Genocidio aquí não tínhamos nada, Yerevan era povoado, uma província nada mais. No século XIX já passou aos russos e ainda era a influência persa que em Arménia no século XIX tivemos

145 Escrevendo sobre a “Guerra contra a Pérsia” para o jornal New York Daily Tribune em 27 de janeiro de 1857, Karl Marx traça um breve histórico das relações entre Rússia e Pérsia, mas também sobre interesses britânicos e russos na nessas porções de território da Ásia, assim como das diferenças entre persas e afegãos. Marx mostra que a guerra de 1826-27 é apenas um momento dessa histórica rivalidade entre russos e persas e que trazia para perto a "Inglaterra como aliado natural”; as áreas de influência das Grandes Potências em disputa, seja no Cáucaso ou em outras partes, remonta a uma história bem anterior ao boom de 1914 . Diz o autor de "O capital":

"A despeito desse antagonismo intenso e universal, existia um ponto de contato entre persas e afegãos - sua hostilidade comum contra a Rússia. A Rússia invadiu a Pérsia pela primeira vez sob Pedro o Grande, mas sem grande vantagem. Alexandre I, mais afortunado, pelo tratado de Gulistan privou a Pérsia de doze províncias, a maior parte ao sul do Cáucaso. Nicolau, pela guerra de 1826-1827, que chegou a o fim pelo tratado de Tourkmantchai, expropriou a Pérsia de vários outros distritos e proibiu-lhe a navegação ao largo de suas próprias costas do Mar Cáspio. A memória das expoliações passadas, as restrições presentes que ela tem que sofrer e o temor de novas restrições, são incitações que concorrem para por a Pérsia em oposição mortal à Rússia. Os afegãos, por seu lado, se bem que não estando jamais implicados em verdadeiros conflitos com a Rússia, estão habituados a considerá-la como o inimigo eterno de sua religião e um gigante pronto a engolir a Ásia. Vendo na Rússia seu inimigo hereditário, persas e afegãos foram levados a considerar a Inglaterra como seu aliado natural. Assim, para manter sua supremacia, a Inglaterra só teria que desempenhar a função do mediador benévolo entre a Pérsia e o Afganistão e mostrar-se o adversário resoluto das restrições russas. Uma demonstração de amizade de uma parte e uma firme resolução de resistência de outra: não era necessário mais nada." Disponível em: https://www.marxists.org/portugues/marx/1857/01/27.htm acesso em 03/07/2017 
mais mesquitas que igrejas, assim que a influência é muitíssima, na língua, na cozinha, em arquitetura também. Bom, agora nosso governo não quer preservar, mas se vais, por exemplo, a Kond que é o barrio antigo se pode ver o estilo persa, as cores, como fazem, como se chama esta parte das mesquitas? Aí se pode ver muito bem. 


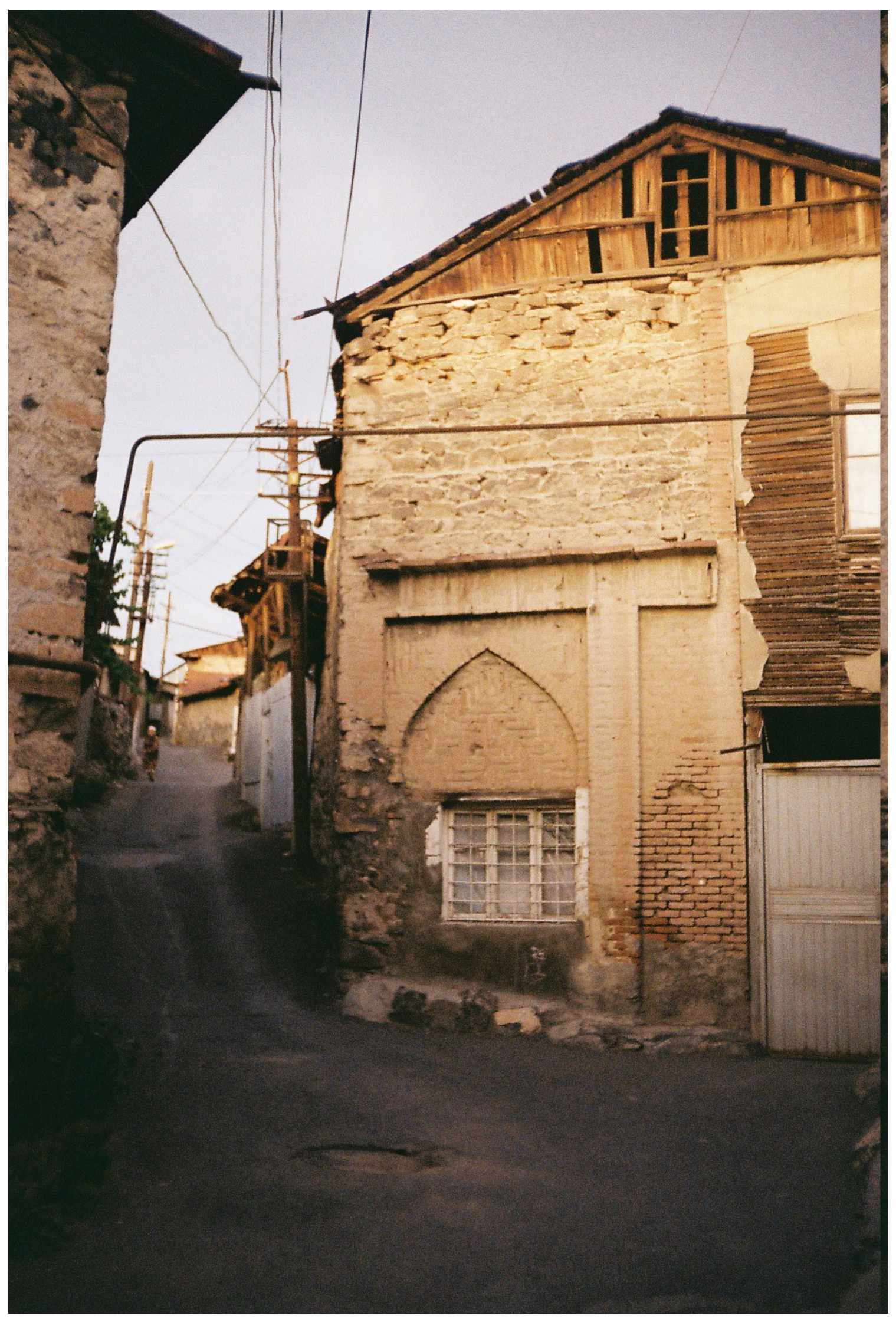

Foto 22 - Casa no bairro de Kond, em Yerevan, com notável influência da arquitetura islâmica. Artur A. C. Camarero em novembro/2016 
Lilit: Os russos quando chegaram, claro, também era como os últimos anos do czarismo, não? Os primeros 50 anos quando chegaram não sabiam, todavia que não fizeram muito na Arménia e depois a onda de influência que podiam influir eram os últimos anos dos romanos que era a dinastia em Rússia, assim creio que não, a influencia persa todavia fica aqui em Armênia, os rusos czaristas me refiro não fizeram muito e ainda há é a história quando chegaran aqui os generais e os soldados, os armênios estavam ajudando os russos que chegavan aqui porque não queriam estar em um país muçulmano, de outra religião em geral justo digo e estávamos lutando por leste, dizem: "broken jar", chamamos Yerevan "broken jar” porque todos eles estavam falando de Yerevan e quando chegou não houve nada, só a fortaleza de Yerevan.

Artur: Então da união aos czaristas passou muito para ter um pouco mais de libertade religiosa? Lilit: Sim, para os russos porque temos Khachatur Abovyan que é o autor armênio que começou a escrever em armênio “slang” (gíria) porque armênio já no século XVIII e XIX não detinha a situação do latim no ano do Renascimento, porque todos estavam escrevendo em Grabar ${ }^{146}$, que é o armênio antígo, mas as pessoas já falava outra língua. Assim que Abovyan foi o primeiro que iniciou a escrever em armênio que se falava e ele tem seu livro "Verk Hayastani”, "Ferida da Armênia” se pode traduzir e diz, a primeira oração é: "que seja bem dito o momento quando os russos entraram em Armênia". Então, para os armênios era algo tão importante depois de sete séculos ter esta liberdade de religião, que também podiam exercer sua religião livremente, era algo muito importante a chegada dos russos.

\section{X) Feminismo de calças curtas}

Lilit: Eu creio que há diferença, mas eu cresci em uma família que não tem desigualdade de gênero, meu pai sempre lavava, varria. Bom, então isto era para mim algo normal, eu creio que toda Armênia é assim, é normal. Mas agora que estamos falando com a gente que veio, que viu a violência que se sucede aqui na Armênia, como em todo o mundo. Me dá muita pena e sim há, existe, não sei, todavia para mim que nunca tive um problema com isso, nas ruas talvez alguém te olhe, os meninos, acontece na Itália, em Portugal, é algo normal, não normal, mas algo que sucede em todos os lugares, não é algo caucásico, não? Eu tenho minha avó que sempre me diz: “por que não te casas? Já está com 23 [anos]...” mas nunca tive a pressão e agora eu olho mais como uma piada, falamos com minha avó e até passou, eu sei que ela toma muito seriamente, mas para mim não, não é uma pressão eu sei que as gerações são diferentes, mas também sei que ninguém pode

146 Grabar é estudado até hoje, inclusive no Departamento de Letras Orientais da FFLCH-USP, e possui uma complexa organização gramatical. 
me fazer, nem minha família, não o fazem, mas se também algum dia lhes passava pela mente querer casar-me, por exemplo, nunca poderiam fazer porque eu não os deixaria, não os deixaria. Eu creio que é algo que poderá dar as mulheres porque têm muitos casos, há mulheres que, porque sempre dizem "os homens fazem isso”, mas não vemos a outra parte e para as mulheres também têm os esteriótipos que são muito fortes e para eles também, sabem que se vão a trabalhar com “este homem” tem que ter outros serviços, por exemplo, não só ser uma secretária, mas também outros serviços e eles estão bem com isso, para eles é totalmente “ok”. Assim que não é só o homem que lhes faz fazer isso, mas também eu creio que é um pouco isso passa também, é algo de empoderar as mulheres, romper os esteriótipos e dizer-lhes que “não, não é assim”.

Artur: E que outros serviços seriam esses?

Lilit: Bom, por exemplo... preparar café, não? Isto é o menor que é preparar café que te diga seu chefe que prepares e tens que preparar.

Artur: Como coisas extras que não são pagas...

Lilit: Sim, sim e ademais é a coisa que "tu é mulher e eu sou seu chefe, eu sou o chefe", então tu tens que fazer, estas coisas, mas de novo não posso dizer nada objetivo sobre isso... e meus amigos me dizem "tu és assim, não toda Armênia", não significa que toda a Armênia, mas se me perguntas, se me fizesse essa pergunta há três anos te diria que aqui na Armênia não temos problemas. Porque eu não tenho realmente, eu vou a casa a qualquer hora, às três, uma e não tenho o medo que vão dizer algo porque sou uma mulher, ponho as calças mais curtas que posso levar e está bem... tenho muitas amigas que dizem “meu irmão não me deixa” ou "o que vão dizer nas ruas?” A mim não me importa, eu sei que posso, toco na madeira (três batidas para espantar o infortúnio) que agora falo se algum dia, não sei, mas não tenho o medo, tampouco salário $e$ trabalho, não sei, mas sim a violência existe, vejo os eventos, as coisas que sucedem lamentavelmente, sei que há. Não vou entrar nessa coisa, eu creio que só sendo eu e trabalhar, porque agora trabalho com os estudantes também sendo eu e trabalhar com eles já é também uma maneira de mostrar-lhes algo, então não tenho que por algo aqui "feminista” ou não sei o quê, dizer-lhes algo “estou aqui para empoderá-los”, não. Eu sendo eu, com minhas calças curtas em seu povoado é algo assim que também sou uma pessoa boa. 
MAPAS REFERENTES À PARTE DOIS 


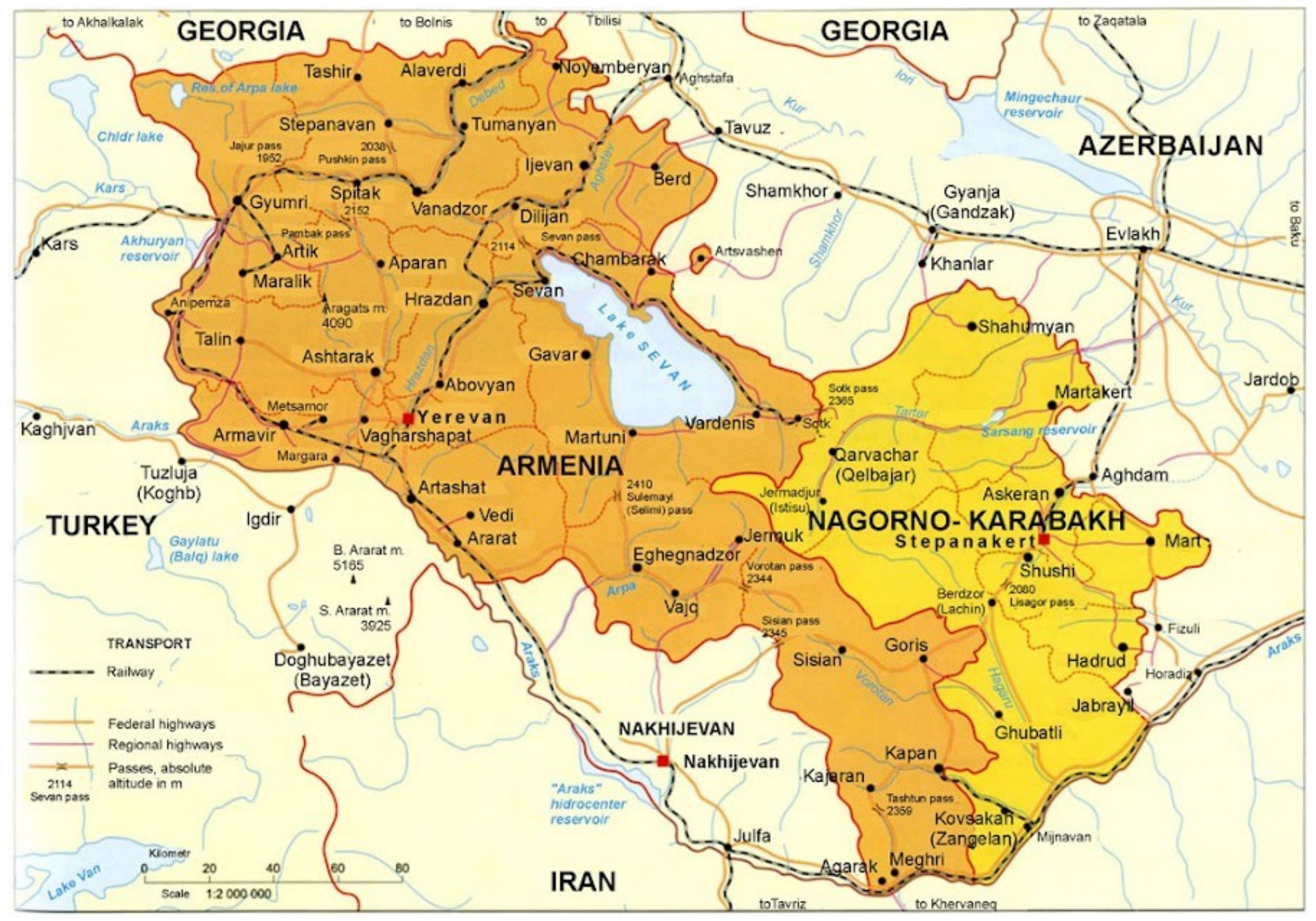

Mapa 2 - Armênia e a região de Nagorno-Karabakh, atualmente a República de Artsakh para os armênios é internacionalmente interpretada como ocupação do território do Azerbaijão. Cidades visitadas e em negrito as cidades citadas ao longo da Dissertação: Abovyan, Dilijan, Goris, Gyumri, Kapan, Meghri, Shushi, Stepanakert, Tashir, Vanadzor, Vedi e Yerevan. 


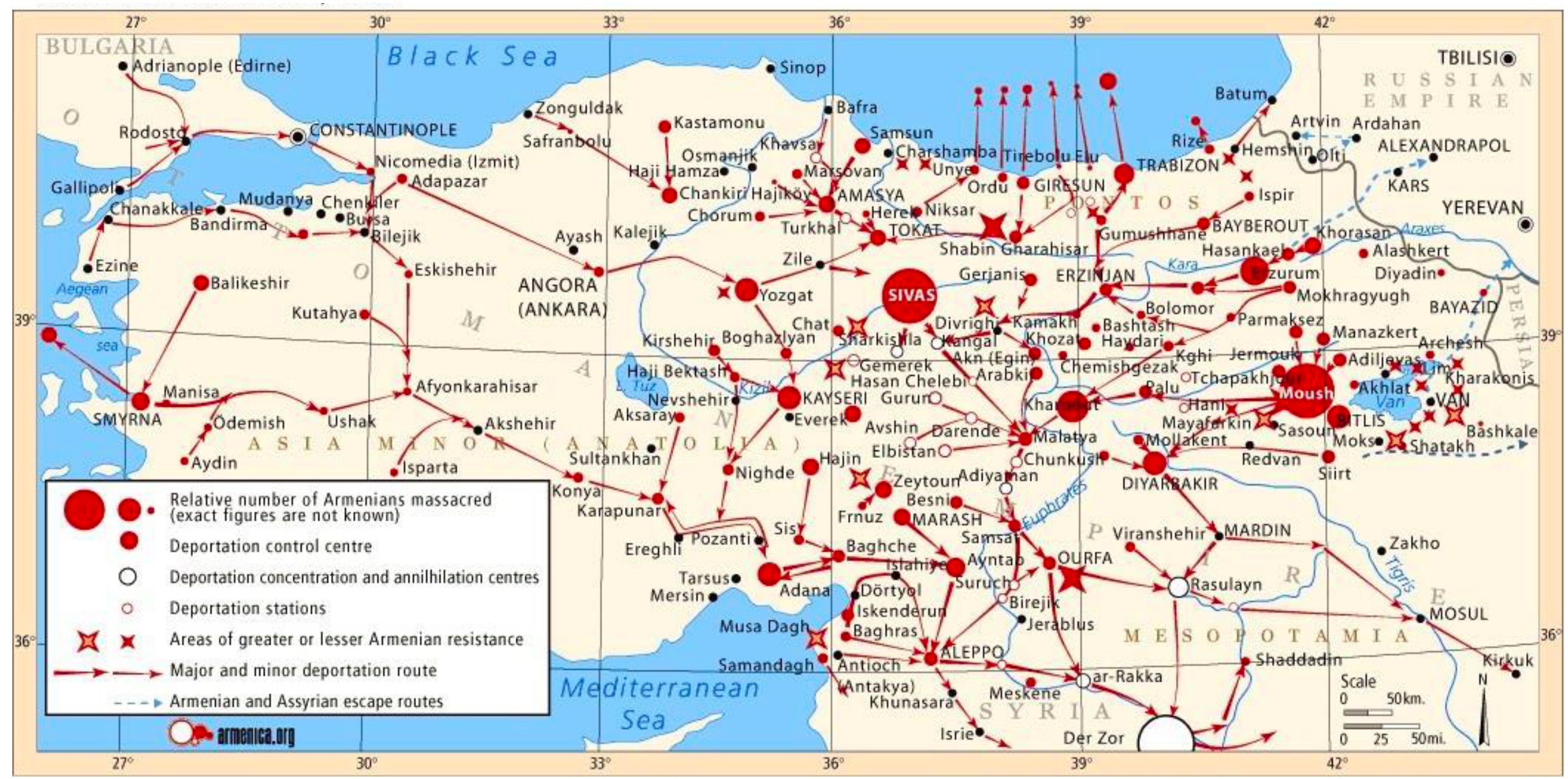

Mapa 3 - As rotas e as estações de deportação, os centros de controle e aniquilação e as resistências ao Genocídio Armênio. 


\section{CONSIDERAÇÕES FINAIS}

Ao encerrar essa Dissertação nos fica a impressão de que nenhum assunto foi encerrado propriamente, o que faz dessas considerações finais um terreno movediço. Também nos parece reafirmar, depois que o processo de elaboração e escrita foi concluído, que em termos formais o texto apresenta heterogeneidade entre suas partes. A primeira mais próxima ao clássico formato dissertativo e a segunda entre relatos e análises, compondo uma totalidade de textos em fragmentos que, ora encerram um assunto, ora apenas apontam para relações das partes com o todo. Tentamos, em ambas as partes, pensar o problema da identidade armênia - a chamada armenidade - na tensão de suas formas de representação spyurqhay (a diáspora armênia de todo o mundo) e as de hayastantsi (de quem nasce na Armênia), e isso não como resultado de uma união cultural que remonta a períodos pré-cristãos mas como parte da totalidade social especificamente capitalista. Desta feita, a armenidade entrelaça relações sociais e movimenta representações identitárias. Atentando para a dimensão produtiva destas representações, fomos vendo como as mesmas definem práticas econômicas, disputas jurídicas relativas ao reconhecimento e às reparações do Genocídio Armênio, o espetáculo da política no interior do país e nos países da chamada diáspora, bem como as relações e formas que tomam o financiamento do Estado armênio administrador da guerra de Nagorno-Karabagh que, como pudemos investigar, também se realiza por meio de capitais oriundos da assim chamada diáspora.

A primeira parte fala da chegada dos armênios que imigram à América como refugiados dos conflitos e massacres no interior do Império Otomano ocorridos durante a guerra de 1914. Buscamos compreender ali a formação da Comunidade Armênia de Osasco (CAO) junto ao processo que relaciona este bairro (antes subúrbio) com a urbanização de São Paulo em seu longo processo de “internalização da metrópole”, para usar os termos de Giavarotti (2012). Essas reflexões tentam articular diferentes escalas e o processo de autonomização das fontes de rendimento (terra - renda da terra, trabalho - salário e capital - juros) em sua relação com a formação do que Marx chamou de "Lei geral da acumulação capitalista” e cuja dinâmica implica em concentração e centralização do capital sobre a reprodução da superpopulação relativa até seu momento de colapso, ou, como apresenta Damiani (2004), de “urbanização crítica”. Nesse sentido, o bairro em particular é o lugar da indústria, mas também da moradia dos trabalhadores, o que implica ao mesmo tempo no surgimento da pequena propriedade imobiliária, complexificando a análise por poder ser personificada por trabalhadores com diferentes trajetórias de mobilização, conforme tematizado no caso do loteamento realizado pela Cerâmica Hervy. Remontar esse 
processo nos colocou diante de questões que relacionam a identidade armênia e sua representação colada à produção de calçados, esteja o armênio na posição personificada de capitalista ou de trabalhador. Tal representação, que embora tenha materialidade vivida e muita história, tanto nos destinos da diáspora como naquela inspirada pela armenidade trans histórica, acaba por esconder as relações de dominação e exploração conformadas no interior da comunidade armênia em questão, do mesmo modo como esconde a dominação patriarcal do valor-dissociação que demarca rigidamente os papéis de gênero dentro dessa comunidade. Trazida pela experiência de pesquisa de campo e exposta nos "Relatos platinos”, figura como importante questão, ainda nessa parte do texto, também aquela das diferentes formas de representação da armenidade entre spyurqhay (assim chamada diáspora armênia) e hayastantsi (referente a quem nasce na Armênia).

Os pequenos itens, especialmente na segunda parte, partem de relatos e tentam abordar criticamente a realidade vivida em seus “fenômenos empíricos”, durante a breve experiência de viver na Armênia (entre agosto a novembro de 2016), e cuja leitura se deu às voltas com os conceitos e categorias do debate marxista e, mais especificamente, os mais próximos às interpretações de Robert Kurz e Roswitha Scholz. Acreditamos, assim, que a parte supracitada foi aquela na qual melhor enredamos a forma do texto como uma colcha de relatos e retalhos de teoria. Falou-se bastante sobre a construção da armenidade dos diaspóricos, ou spyurqhay e os hayastantsi, nascidos na Armênia, destacando pontos em comum e pontos divergentes acerca dessa personificação diante da relação capitalista e por meio das representações da esfera autonomizada da cultura que, embora parcelar, acaba por produzir seus discursos dotando-os de uma capacidade explicativa totalizante. Igual, falou-se bastante sobre a guerra de 1914 como inauguração da mobilização geral. A guerra de 1914 é apresentada por Gaudemar (1981) como um novo patamar de mobilização do qual a modernização jamais poderá recuar, a mobilização geral. Economia de guerra permanente e estado exceção tornada regra. Dessa perspectiva, todos os esforços estão voltados para a produção, fazendo da guerra uma constante necessária à acumulação de capitais, que hoje se demonstra frágil e cada dia mais suscetível a crises. A população do e para o capital mundial é que faz tudo isso acontecer na ilusão do sujeito escravo do dinheiro, que nesses termos se converte numa inescapável relação social entre mercadorias. Uma relação que rege as pessoas para transformar um dinheiro em dois, sugando trabalho abstrato que ainda sobrou entre pacificadas áreas de consumo e guerra civis mundiais, entre tráfico escravo a céu aberto e muros xenófobofascistas a se proliferar no discurso e na materialidade. Falou-se em alguns momentos mais detidos, mas sempre com natural dificuldade, sobre o lugar da mulher na relação social capitalista, particularmente armênia: a dinâmica do valor-dissociação que se asselvaja nos tempos de hoje, o cenário da sociedade patriarcal em sua imensa acumulação de barbárie. Sem nunca esquecer de 
Walter Benjamin e assim encontrando nos documentos de cultura os documentos de barbárie, lembramos que, deitado eternamente em berço esplêndido, o nacionalismo entre milhares de guerras se arrasta junto com a ideia de acumulação infinita. Definharemos junto com o capitalismo?

No contemporâneo capitalismo sem substância de valor, a relação social se fundamenta numa ficção de acumulação de capitais e a experiência subjetiva sujeitada a isso tudo se ancora na simulação e no espetáculo. A vida em comunidade, as tradições de outrora que fundamentam os mitos fundadores da armenidade trans histórica, hoje são parte do espetáculo das representações de identidade. E essa pesquisa é mais uma expressão disso.

O contemporâneo capitalismo de cassino, caracterizado aqui como sociedade acumuladora de barbárie, reaviva a lógica identitária e a tensa posição in e out em meio aos espólios que a modernização nos deixa. O feitiço da cultura sem determinação histórica e material quer achar quem são os originais, os mais tradicionais. Assumir uma identidade, uma posição marcada no discurso? Somos todos deslocados de alguma guerra. Na guerra do dinheiro sobre as pessoas, no reordenamento populacional: quem é cidadão? O burguês do Estado, o eleitor registrado, o sujeito do valor.

Cem anos depois, na crise do trabalho, a mobilização de todos não apenas continua na moda como também se intensificou ao ritmo das bolhas financeiras que tomam aparências das mais diversas na flexi-existência, nos mobilizando a todo momento, dominando todo e qualquer tempo de não trabalho em vários níveis das relações sociais mediadas por espetáculos, redes sociais, criptografia, dinheiro vivo ou à prazo, sendo pai, mãe, estudante, desempregado, presidiário, ou bom profissional. O jogo é jogado e se o lastro do dinheiro é a bomba, para fazer dinheiro é preciso sangue. Noutras palavras, a matéria-prima do dinheiro é o sangue. E a sociedade que se arrasta desde que a mobilização geral virou regra, nos últimos cem anos, é a sociedade acumuladora de barbárie, na qual se insiste em jogar o jogo sobre o tabuleiro de xadrez do Estado nacional.

Sim, o dinheiro realizou o plano "humano" da mobilidade perfeita (Gaudemar, 1981), ele gira um mundo em um clique e fronteira para ele não é problema. Mas observe os supérfluos, as pessoas varridas por alguma guerra e as suas “desumanas" travessias pelos desertos, mares e fronteiras, com ou sem papel. 


\section{Agradecimentos}

Agradeço:

a todas as pessoas que concederam entrevistas ao longo desses anos de pesquisa mesmo que aqui não estejam publicadas. Às pessoas com fui conversando de diversas maneiras ao longo do tempo de estudos e pesquisas, nas conversas breves, nas indicações, nas lembranças.

Às famílias armênias Stepanyan, Podosyan e Grigoryan que me receberam em Yerevan e Gyumri entre agosto e setembro de 2016, e também ao programa BirthRight Armenia por possibilitar minha ida à Armênia.

À Maria Florencia Demerjian, que me ajudou demais da conta e à sua família em Buenos Aires. À Greta, que me presenteou com o livro de Akçam, tão importante para a elaboração deste texto, em Buenos Aires. À Cristina Nerguezian, por aquela nossa charla em Montevidéu que tanto contribuiu para a pesquisa.

Ao Narcizo Júnior, secretário da CAO, desde o começo muito aberto a me ajudar, ao Setrak Kachikian, pela importante entrevista, ao Missak Kachikian, por disponibilizar o histórico dos imóveis da CAO e ao César Guludjian, pela prosa. Ao James Onnig por tantos contatos, e boas conversas.

À minha mãe, que além de tanta coisa indizível, fez e faz críticas importantes ao lugar da mulher na comunidade armênia. Ao meu pai, esse velho jovem sonhador que pouco depois do TGI me sugeriu a pesquisa sobre os armênios da banda do Prata, minhas irmãs, meus sobrinhos que me refazem moleque e que talvez leiam esse trabalho algum dia, minha tia Luci, armênia não-armênia como nós todos e à minha avó, esse estranho ímpar, voraz desnaturalizadora da assim chamada armenidade. À Marina, maravilhosa companheira nessas many roads, do Chuí até Buenos Aires em nossas bravas bicicletas e do Cáucaso à Ibéria. Dedico a ela os relatos de viagem, pois nessa páginas estão muitas conversas nossas e muitas informações das observações dela, especialmente sobre a situação da mulher na Armênia.

Ao Allan, amigo astuto e parceiro de campo de estudo que sempre ajudou com precisas indicações bibliográficas e me inspirou a bater de frente sempre que possível com os racistas desde aquela conversa ríspida contra o antisemtismo naturalizado naquela noite, pouco antes de embarcar à Armênia, em Barra Grande, Bahia. À Carol, minha amigona desde os tempos da extinta Rádio Várzea e parceira de estudos há quase dez anos, que sempre incentivou essa pesquisa e a ideia dos cadernos de campo ganharem força no texto final. Ao Daniel, parceiro para tantos sons e brisas, que também me animou a usar os relatos na redação final. Ao Zé Rafael, mais um dos irmãos que não tive e que a vida foi trazendo, segurou nossa casa enquanto viajava junto com Tatá, essa pequena 
grande pensadora que tanto me entende com sua sensibilidade que corta caminhos. Sua ajuda na reta final foi fundamental. Francis ou Chico, amigo dessa vida que tanto me ajudou a tornar esse texto mais inteligível, mas isso é só um pedaço da coisa toda. Ele e Marizinha foram topar comigo lá na Armênia e puderam ver um pouco do que foi meu cotidiano lá, quando já estava cansado de tudo aquilo. O companheirismo de viagem dos dois me tranquilizou e deu fôlego para o resto da viagem, também por isso os agradeço, além da paciência nessa estrada toda. Ao citado primo fotógrafo Norair e família, por compartilhar conversas, dicas para a estrada e por me colocar em contato com Mirhan em Istambul. À Ana Maris, pela leitura importante pouco antes da entrega e por nossas divertidas conversas ao longo dessa trajetória.

Ao Carlão pela disposição de sempre e paciência de leitura, além da renovada dica: mais do que cartografia na leitura dos outros, cartografia do próprio texto para ir entendendo e estranhando o próprio argumento. À Marta por ter o coração tão generoso desde que a conheci, grande curiosa sobre armenidades e apoiadora das andanças de pesquisa.

Aos bravos pesquisadores e parceiros Heitor Loureiro, sempre revelando mais sobre os armênios e suas conexões pelo mundo, e ao Pedro Porto, com suas pistas importantes sobre identidade.

À Deize Crespim Pereira e ao Sarkis Sarkissian do DLO-FFLCH-USP.

Às pessoas que compõem ou compuseram os grupos de estudos d' O capital, carinhosamente apelidado de "grupo do Barba”, em suas muitas fases e lugares. Às pessoas do grupo do Colapso da modernização às segundas-feiras e do grupo de sexta-feira também no Labur. Ao Dieter que ensinou a toda essa gente, mesmo que tenha sido em um momento de descuido, que grupo de estudos vale mais a pena do que o curso de graduação.

Esta pesquisa foi financiada pela CAPES. 


\section{REFERÊNCIAS BIBLIOGRÁFICAS}

ADORNO, Theodor W. A teoria freudiana e o padrão da propaganda fascista. Margem Esquerda: ensaios marxistas nº7, 2006, p.164-189.

Individuo y organización. In: Escritos sociológicos I - Obra completa, 8.

Traducción: Agustín González Ruiz. Madrid, Espanhã: Ed. Akal, 2004, p. 412-426.

AKÇAM, Taner. Un acto vergonzoso - El Genocidio Armenio y la questión de la responsabilidad turca. - $1^{\circ}$ ed. - Buenos Aires: Colihoe, 2010. Tradução direta do inglês: Eduardo Karsaclian.

ANDERSON, Benedict. Comunidades Imaginadas. São Paulo: Companhia das Letras, 2009 [1983].

ALMEIDA, Ligia Sanchez de. Genocídio Armênio: a história e a “verdade oficial. Revista Vértice - Dep. Letras Orientais - USP, Nº 12, 2012.

BENJAMIN, Walter. Magia e técnica, arte e política. São Paulo: Ed. Brasiliense, 1994.

BRUNETEAU, Bernard. O século dos genocídios: Violências, massacres e processos genocidários da Arménia ao Ruanda. Lisboa. Instituto Piaget, 2008.

CHAHINIAN, Stepan Norair. O poder do vazio: conversando com as pedras na Armênia histórica. Istanbul: Aras, 2015.

CROCHÍK, José Leon. Nota sobre o texto “A teoria freudiana e o padrão da propaganda fascista”, de T. W. Adorno. Margem esquerda: ensaios marxistas nº 7, 2006, p. 159-163.

DADRIAN, Vahakn Norair. Historia del genocidio armenio. Conflictos étnicos de los Balcanes a Anatolia y al Cáucaso. Buenos Aires. Imago, 2008.

Modelo teórico de genocídio, com referência particular ao caso armênio. In: Hades - Revista interdisciplinar - UNIFESP - Vol.1 - Julho/Dezembro, 2017 [1979]. Tradução direta do inglês: Artur A. C. Camarero. Disponível em: http://www.massacres-egenocidios.com.br/hades-vol-1-n-1-jul-dez-20178

DAMIANI, Amélia Luisa. Urbanização crítica e situação geográfica a partir da metrópole de São Paulo. In: Geografias de São Paulo: representação e crise da metrópole. Ana Fani Alessandri Carlos, Ariovaldo Umbelino de Oliveira (organizadores) - São Paulo. Contexto, 2004.

População e geografia. São Paulo: Contexto, 1992. 
DEBORD, Guy. A sociedade do espetáculo. Trad. Estela dos Santos Abreu. Rio de Janeiro: Contraponto, 1997.

FREITAS, Sônia Maria de. Falam os imigrantes: memória e diversidade cultural em São Paulo. São Paulo: Tese de Doutorado em História Social, FFLCH - USP, 2000.

GARNIER, Jean Pierre. Planificación urbana y neoliberalismo en Francia. 2011. Mimeografia.

GAUDEMAR, Jean Paul de. La movilizacion general. Madrid: Las Ediciones de La Piqueta, 1981.

Mobilidade do trabalho e acumulação de capital. Lisboa: Estampa,

1977.

GRIGORIAN, Stella. Inch ka chka and other paradoxical clues into Soviet Armenian Society. Houston, Texas, Rice University, Tese de Doutorado.

GRÜN, Roberto. Negócios \& famílias: armênios em são paulo. São Paulo: Editora Sumaré, 1992.

HARVEY, David. A Geografia disso tudo. In: O enigma do capital. Ed. Boitempo, 2004.

HOBSBAWM, Eric J. Nações e nacionalismo desde 1780. Rio de Janeiro: Paz e Terra, 1990.

KERIMIAN, Nubar. Massacres de Armênios: acompanha Memórias de Naim Bey para Aram Andonian. São Paulo: Comunidade da Igreja Apostólica Armênia do Brasil, 1998.

KURZ, Robert. A guerra de ordenamento mundial: $\mathrm{O}$ fim da soberania e as metamorfoses do imperialismo na era da globalização. Original em alemão: Weltordnungskrieg: Das Ende der Souveränität und die Wandlungen des Imperialismus im Zeitalter der Globalisierung. Versão portuguesa: http://obeco.planetaclix.pt/rkurz133.htm , http://obeco.no.sapo.pt/rkurz166.htm , http://obeco.no.sapo.pt/rkurz175.htm e http://obeco.no.sapo.pt/rkurz179.htm, 2003.

Barbárie, Migração e guerras de ordenamento mundial. Original em Alemão: BARBAREI, MIGRATION UND WELTORDNUNGSKRIEGE. Zur Signatur der gegenwärtigen weltgesellschaftlichen Situation in www.exit-online.org. Texto revisto de uma conferência proferida pelo autor em 23.01.2005 no Fórum Social Mundia em Porto Alegre. Publicado In: Serviço Pastoral dos Migrantes. (Org.) Travessias na desordem global - Fórum Social das Migrações. São Paulo: Paulinas, 2005.

O colapso da modernização: Da derrocada do socialismo de caserna à crise da economia mundial. Rio de Janeiro: Paz e Terra, 1992.

A realidade irreal. In Últimos combates. Petrópolis - RJ: Editora Vozes, 1997a.

1997b.

O pós-imperialismo. In Últimos combates. Petrópolis - RJ: Editora Vozes,

. Totalitarismo econômico. Artigo publicado na Folha de São Paulo em 22 de Agosto de 1999. Disponível em: http://www1.folha.uol.com.br/fsp/mais/fs22089916.htm . 
Virtudes femininas, a crise do feminismo e a gestão pós-moderna. Publicado na Folha de São Paulo 09.01.2000 com o título O eterno sexo frágil. Original Weibliche Tugenden em www.exit-online.org. Disponível em: http://obeco.planetaclix.pt/rkurz42.htm

LEFEBVRE, Henri. Reflexões sobre a política do espaço, in: Espaço e política, Ed. UFMG, Belo Horizonte: 2008.

LENINE, Vladimir I. O imperialismo, fase superior do capitalismo. In Obras Escolhidas vol.1. Editora Alfa-Ômega. São Paulo, 1979 [1916].

LOUREIRO, Heitor de Andrade Carvalho. O comunismo dos armênios de São Paulo (19351969). São Paulo: Pontífica Universidade Católica, Dissertação de Mestrado, 2012.

Genocídio Armênio (1915-1923): massacre, deportações, expropriação. In: ZAGNI, Rodrigo Medina \& BORELLI, Andrea (org.). Conflitos Armados, Massacres e Genocídios: constituição e violações do direito à existência na era contemporânea. São Paulo: Fino Traço, 2013.

MARCUSE, Herbert. Algumas implicações sociais da tecnologia moderna. In:Tecnologia, guerra e fascismo. Tradução: Maria Cristina Vidal Borba. São Paulo: Ed. UNESP, 1999, p.73-104.

MARX, Karl. O Capital - Crítica da Economia Política. Livro I, tomo I (volume 1). São Paulo: Abril Cultural, 1985.

O Capital - Crítica da Economia Política. Livro I, tomo I (volume 2). São Paulo: Abril Cultural, 1984.

. O Capital - Crítica da Economia Política. Livro III, tomo II (volume 2). São Paulo: Abril Cultural, 1983.

OLIVEIRA, Francisco de. A emergência do modo de produção de mercadorias: uma interpretação teórica da economia da República Velha no Brasil (1889-1930). In: OLIVEIRA, Francisco de. A Economia da dependência imperfeita. Rio de Janeiro: Edições Graal, 1977.

PENTEADO, Antonio Rocha, PETRONE, Pasquale. São Caetano do Sul e Osasco, subúrbios industriais. In: Os subúrbios paulistanos - Volume IV. A cidade de São Paulo: estudos de geografia urbana. Aroldo de Azevedo (organizador). São Paulo. Companhia Editora Nacional, 1958.

PORTO, Pedro Bogossian. Construções e reconstruções da identidade armênia no Brasil (R.J. e S.P.). Niterói: Universidade Federal Fluminense, Dissertação de Mestrado, 2011.

É o renascimento de uma identidade nacional! A relevância da Guerra e do Genocídio no nacionalismo armênio. In: Hades - Revista interdisciplinar - 
UNIFESP - Vol.1 - Julho/Dezembro, 2017. Disponível em: http://www.massacres-egenocidios.com.br/hades-vol-1-n-1-jul-dez-20178

SAPSEZIAN. Aharon. História da Armênia: drama e esperança de uma nação. Rio de Janeiro: Paz e Terra, 1988.

O cristianismo armênio. São Paulo: Bentivegna Editora, 1997.

SCHOLZ, Roswitha. O valor é o homem. Original Der Wert ist der Mann in www.exit-online.org. Publicado na revista Krisis $\mathrm{n}^{\circ}$ 12, 1992, pp. 19-52. Tradução portuguesa de José Marcos Macedo (que agradece a Robert Schwarz pela ajuda na tradução de termos específicos) publicada em S. Paulo, NOVOS ESTUDOS - CEBRAP, nº 45 - julho de 1996, pp. 15-36.

\section{Cristóvão Columbus Forever?. Original CHRISTOPH KOLUMBUS}

FOREVER? Zur Kritik heutiger Landnahme-Theorien vor dem Hintergrund des „Kollaps der Modernisierung“. Publicado na revista EXIT! Krise und Kritik der Warengesellschaft, n ${ }^{\circ} 13$ (01/2016), pag. 46-100, [EXIT! Crise e Crítica da Sociedade da Mercadoria, $n^{\circ} 13$ (01/2016)], ISBN978-3-89502-400-9, 192 p., 13 Euro, Editora: Horlemann Verlag, Lindenallee 9, 16278 Angermünde, Deutschland, E-mail: info@horlemann-verlag.de, http://www.horlemann.info/. Tradução de Boaventura Antunes (05/2016)

SEABRA, Odette C. de Lima. Os meandros dos rios nos meandros do Poder. Tietê e Pinheiros: valorização dos rios e das várzeas na cidade de Paulo. Tese de doutoramento. São Paulo: FFLCH/USP, 1986.

SMITH, Neil. A gentrificação generalizada: de uma anomalia local à “regeneração" urbana como estratégia urbana global in: De volta à cidade. Ed. Annablume, São Paulo: 2006

SPINELLI, Daniela. Reflexões sobre memória, esquecimento e recalque do genocídio armênio. Interdisciplinar: Revista de Estudos em Língua e Literatura, v. 13, p. 7-21, 2011

SUMMA, Renata de Figueiredo. Vozes armênias: memórias de um genocídio. Revista de Ética e Filosofia Política - UFJF, vol. 10 - nº 1, 2007.

TOYNBEE, Arnold J. Atrocidades turcas na armênia em 1915: denúncias de grandes personalidades / com um discurso proferido por Lorde Bryce na Câmara de Londres. São Paulo: Paz e Terra, 2003.

VARELA, Brisa. La visibilización de la experiência migratoria feminia em situación de genocidio. La Aljaba, vol. XI,p. 193-210, 2007. 